\title{
Analysis of Organic Carbon and Moisture in Hanford Single-Shell Tank Waste
}
J. J. Toth
J. G. Hill
P. G. Heasler
P. D. Whitney
M. E. Lerchen

May 1995

Prepared for

Westinghouse Hanford Company

Waste Tank Organic Safety Program

and the U.S. Department of Energy

under Contract DE-AC06-76RLO 1830

Pacific Northwest Laboratory

Operated for the U.S. Department of Energy

by Battelle Memorial Institute 


\section{Analysis of Organic Carbon and Moisture in Hanford Single-Shell Tank Waste}
J. J. Toth
J. G. Hill
P. G. Heasler
P. D. Whitney
M. E. Lerchen

May 1995

Prepared for

Westinghouse Hanford Company

Waste Tank Organic Safety Program

and the U.S. Department of Energy

under Contract DE-AC06-76RLO 1830

Pacific Northwest Laboratory

Operated for the U.S. Department of Energy

by Battelle Memorial Institute 


\title{
DISCLAIMER
}

This report was prepared as an account of work sponsored by an agency of the United States Government. Neither the United States Government nor any agency thereof, nor Battelle Memorial Institute, nor any of their employees, makes any warranty, expressed or implied, or assumes any legal liability or responsibility for the accuracy, completeness, or usefulness of any information, apparatus, product, or process disclosed, or represents that its use would not infringe privately owned rights. Reference herein to any specific commercial product, process, or service by trade name, trademark, manufacturer, or otherwise does not necessarily constitute or imply its endorsement, recommendation, or favoring by the United States Government or any agency thereof, or Battelle Memorial Institute. The views and opinions of authors expressed herein do not necessarily state or reflect those of the United States Government or any agency thereof.

\author{
PACIFIC NORTHWEST LABORATORY \\ operated by \\ BATTELLE MEMORIAL INSTITUTE \\ for the \\ UNITED STATES DEPARTMENT OF ENERGY \\ under Contract DE-AC06-76RLO 1830
}

Printed in the United States of America Available to DOE and DOE contractors from the Office of Scientific and Technical Information, P.O. Box 62, Oak Ridge, TN 37831; prices available from (615) 576-8401. FTS 626-8401.

Available to the public from the National Technical Information Service, U.S. Department of Commerce, 5285 Port Royal Rd., Springfield, VA 22161. 


\section{DISCLAIMER}

Portions of this document may be illegible in electronic image products. Images are produced from the best available original document. 
PNL-10360

UC-

2030

\title{
Analysis of Organic Carbon and Moisture in Hanford Single-Shell Tank Waste
}

\author{
J. J. Toth \\ P. G. Heasler \\ M. E. Lerchen \\ J. G. Hill \\ P. D. Whitney
}

May 1995

Prepared for

Westinghouse Hanford Company

Waste Tank Organic Safety Program

and the U.S. Department of Energy

under Contract DE-AC06-76RLO 1830

Pacific Northwest Laboratory

Richland, Washington 99352

DISTRIBUTION OF THIS DOCUMENT IS UNLIMITED

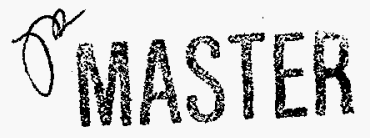





\section{Summary}

This report documents a revised analysis performed by Pacific Northwest Laboratory (PNL) involving the organic carbon laboratory measurement data for Hanford single-shell tanks (SSTs) obtained from a review of the laboratory analytical data. This activity, undertaken at the request of Westinghouse Hanford Company (WHC), has as its objective to provide a best-estimate, including confidence levels, of total organic carbon (TOC) and moisture in each of the 149 SSTs at Hanford. The TOC and moisture information presented in this report is useful as part of the criteria to identify SSTs for additional measurements, or monitoring for the Organic Safety Program.

In April 1994, an initial study of the organic carbon in Hanford single-shell tanks was completed at PNL. That study reflected the estimates of TOC based on tank characterizations datasets that were available at the time. Also in that study, estimation of dry basis TOC was based on generalized assumptions pertaining to the moisture of the tank wastes. The new information pertaining to tank moisture and TOC data that has become available from the current study influences the best estimates of TOC in each of the SSTs. This investigation of tank TOC and moisture has resulted in improved estimates based on waste phase: saltcake, sludge, or liquid.

This report details the assumptions and methodologies used to develop the estimates of TOC and moisture in each of the 149 SSTs at Hanford. Major factors included in the study are:

1. Determining the effect of phase on TOC and moisture concentration. Phase effects on TOC and moisture were found to be significant.

2. Grouping tanks according to the SORWT (Sort on Radioactive Waste Type) model to establish waste type.

3. Estimating the moisture levels for each phase (saltcake, sludge and liquid) in each of the 149 SSTs.

4. Estimating the TOC and moisture based on an Analysis of Variance Model (ANOVA), allowing for conservative estimates of each of the 149 SST conditions. For those tanks with wastes that have not been measured, attributes of tanks in the same SORWT group and phase are used to estimate tank waste conditions.

5. Combining the estimates of TOC and Moisture to postulate a probability that the waste in each tank exceeds the preliminary safety criteria.

The moisture of saltcakes was found to be correlated to waste type, tank ventilation, and interim stabilization (jet-pump) status. The saltcake phase was found to be the waste of most concern from a safety perspective, and the least known. Saltcake comprises one-third of all 
single-shell tank waste, but only one of the 65 saltcake tank wastes has been sampled since 1980 . There is a high degree of uncertainty surrounding the saltcake waste TOC estimates. Interim stabilization by jet-pumping and active tank ventilation were found to be significant in reducing moisture level in saltcake wastes.

The methodology for estimating the distribution and levels of TOC in SSTs used a logarithmic scale that was reported in the previous study. The methodology grouped tanks according to waste type using the SORWT grouping method. The SORWT model categorizes Hanford SSTs into groups of tanks expected to exhibit similar characteristics based on major waste types and processing histories. The methodology to estimate moisture and TOC makes use of laboratory data for the particular tank and information about the SORWT group of which the tank is a member. 


\section{Acronyms and Initialisms}

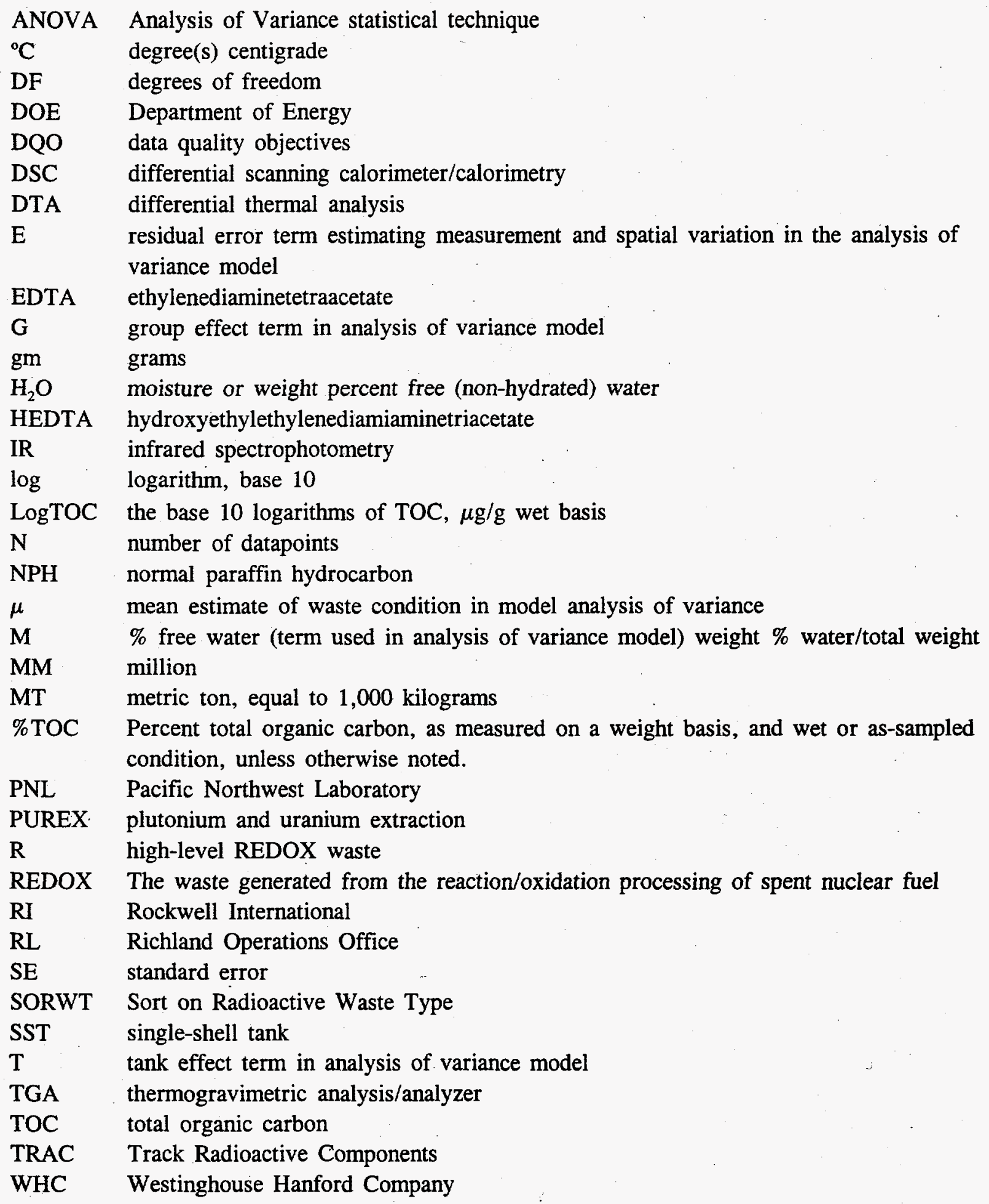





\section{Contents}

Summary $\ldots \ldots \ldots \ldots \ldots \ldots \ldots \ldots \ldots \ldots \ldots \ldots$ iii

Acronyms and Initialisms $\ldots \ldots \ldots \ldots \ldots \ldots \ldots$

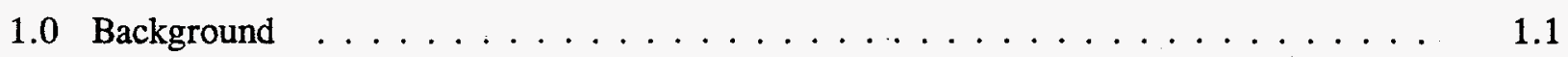

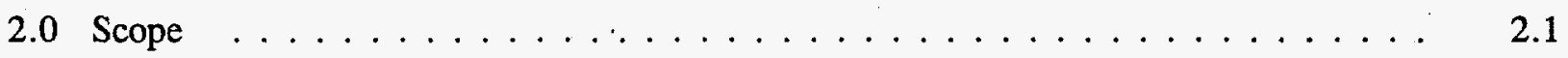

3.0 Study Approach, Data Sources, and Assumptions $\ldots \ldots \ldots \ldots . \ldots \ldots$

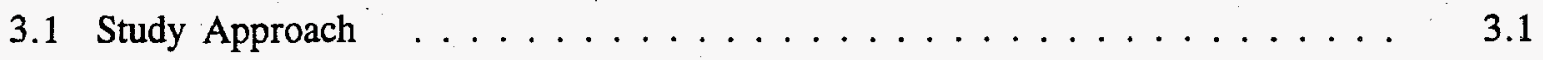

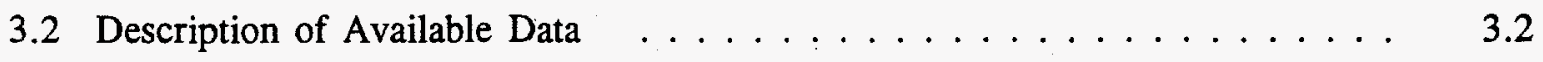

3.3 Approach to Statistical Analysis $\ldots \ldots \ldots \ldots \ldots \ldots$

3.3 .1 ANOVA Model for TOC $\ldots \ldots \ldots \ldots \ldots \ldots$

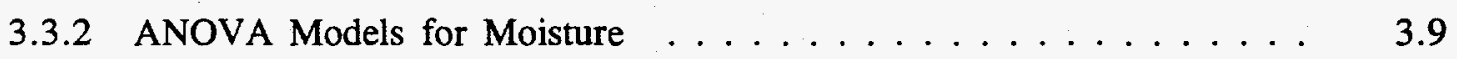

3.4 Study Assumptions $\ldots \ldots \ldots \ldots \ldots \ldots \ldots \ldots \ldots \ldots \ldots$

4.0 Evaluations of SSTs Using ANOVA Models $\ldots \ldots \ldots \ldots \ldots \ldots . \ldots \ldots$

4.1 Appropriate Distribution of TOC Data $\ldots \ldots \ldots \ldots \ldots \ldots$

4.2 Importance of Waste Phase $\ldots \ldots \ldots \ldots \ldots . \ldots \ldots . \ldots . \ldots . \ldots . \ldots$

4.3 Nominal Characteristics of Waste Phase . . . . . . . . . . . . . 4.4

4.4 Significance of SORWT Grouping $\ldots \ldots \ldots \ldots \ldots$

4.5 Nominal Composition of SORWT Groups $\ldots \ldots \ldots \ldots$

4.6 Effect of Jet-Pumping, Ventilation, and Waste Type on Saltcake Moisture $\quad . \quad 4.6$

4.7 Comparison of TOC Measurement Data $\ldots \ldots \ldots \ldots$

5.0 ANOVA Model Results $\ldots \ldots \ldots \ldots \ldots \ldots \ldots \ldots \ldots \ldots$

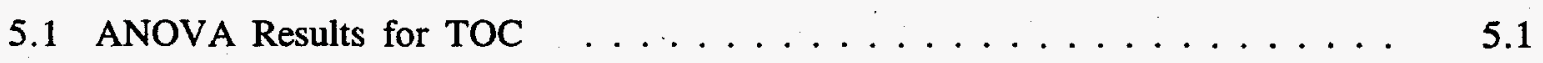

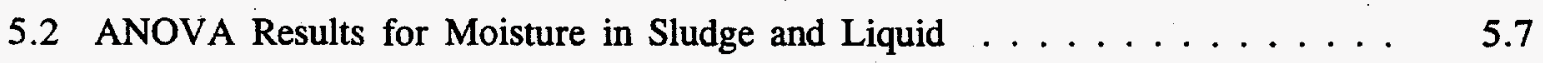


5.3 ANOVA Results for Moisture in Saltcake $\ldots \ldots \ldots \ldots \ldots$

5.4 Exceedance Probabilities for the Worst $5 \%$ of the Waste $\ldots \ldots \ldots . \ldots$

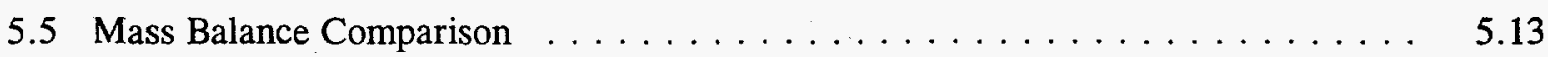

5.6 Comparison of Present Results with Previous Watchlist Tanks $\ldots \ldots \ldots \ldots$

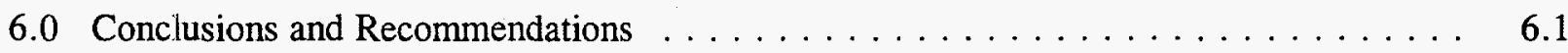

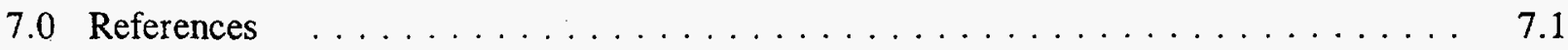

Appendix A - Phase Inventory for 149 Single-Shell Tanks $\ldots \ldots \ldots \ldots \ldots$. . . . . .

Appendix B - Nominal Characteristics of Each Phase $\ldots \ldots \ldots \ldots \ldots \ldots$

Appendix C - Descriptive Tank Statistics by Sort on Radioactive Waste Type . . . . . . . C.1

Appendix D - Description of Sort on Radioactive Waste Types $\ldots \ldots \ldots \ldots \ldots$. . . . .

Appendix E - Analytical Techniques for Percent Water and TOC Measurements $\ldots \ldots . \ldots$ E.1

Appendix F - Laboratory Measurement Sample Dataset $\ldots \ldots \ldots \ldots \ldots \ldots$. . . . . .

Appendix $G$ - Moisture Estimates for 149 Single-Shell Tanks $\ldots \ldots \ldots \ldots$. . . . . . G.1

Appendix $\mathrm{H}$ - Total Organic Carbon Data not Included in ANOVA Estimates $\ldots \ldots . . . . \quad$ H.1

Appendix I - Single-Shell Tank Safety Criteria Exceedance Probability $\ldots \ldots \ldots \ldots$. . . I.1

Appendix J - TOC Estimates for 149 Single-Shell Tanks $\ldots \ldots \ldots \ldots \ldots \ldots \ldots$. . . . . .

Appendix K - TOC Inventory Estimates for 149 Single-Shell Tanks $\ldots \ldots \ldots \ldots$. . . . . . K

Appendix $\mathrm{L}$ - Saltcake Waste Moisture Grouping $\ldots \ldots \ldots \ldots \ldots \ldots \ldots$

Appendix M - SORWT Group Data for 149 Single-Shell Tanks $\ldots \ldots \ldots \ldots \ldots$. . . . . . . 


\section{Figures}

4.1 Histogram of Entire TOC Dataset $\ldots \ldots \ldots \ldots \ldots \ldots \ldots \ldots \ldots \ldots \ldots$

4.2 Histogram of Entire TOC Dataset, Logarithmic Transformation $\ldots \ldots \ldots \ldots . \ldots$

4.3 Saltcake Moisture Data Grouped According to Categories Shown in Table $4.6 \ldots \ldots$. . . 4.8

4.4 TOC Measurements (\%TOC) for Liquid Samples Over Time for Four Selected

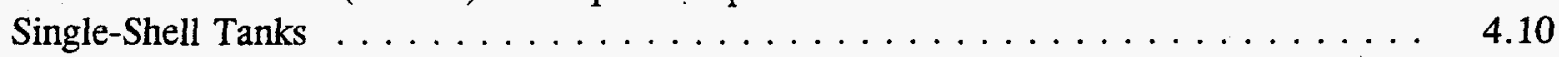

5.1 Model Terms for Sludge TOC Phase Waste $\ldots \ldots \ldots \ldots \ldots \ldots$

5.2 Plot of Median Sludge Estimates Versus Data for Selected Tanks $\ldots \ldots \ldots . . \ldots$

5.3a Quantile/Quantile Plots for the Terms; T (tank) Terms from the Liquid ANOVA Fit $\ldots . \quad 5.4$

5.3b Quantile/Quantile Plots for the Terms, G (SORWT group) Terms from the Liquid

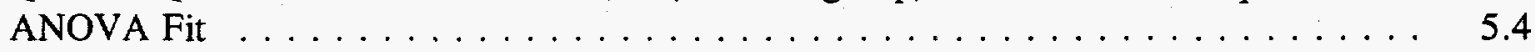

5.3c Quantile/Quantile Plots for the Terms, E (residuals) Terms from the Liquid

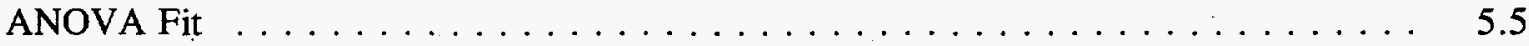

5.4 Preliminary Organics Tank Safety Criteria Identified by the TOC Moisture

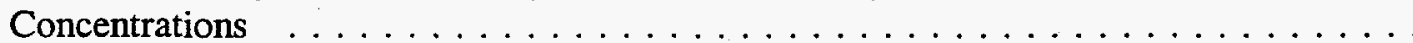

5.5 ANOVA Estimates for the Median, Worst 5\% of the Waste, and 95\% Confidence Bound on the "Worst $5 \%$ " of the Liquid Phase Tank Wastes $\ldots \ldots \ldots \ldots \ldots \ldots$

5.6 ANOVA Estimates for the Median, Worst 5\% of the Waste, and 95\% Confidence Bound on the "Worst $5 \%$ " of the Sludge Phase Tank Wastes $\ldots \ldots \ldots \ldots \ldots$

5.7 ANOVA Estimates for the Median, Worst $5 \%$ of the Waste, and $95 \%$ Confidence Bound on the "Worst 5\%" of the Saltcake Phase Tank Wastes 


\section{Tables}

3.1 Distribution of TOC Measurements According to Tank $\ldots \ldots \ldots \ldots$

3.2 Distribution of Measurement Results by Phase $\ldots \ldots \ldots \ldots \ldots \ldots \ldots$

3.3 Distribution of Moisture Measurements According to Tank $\ldots \ldots \ldots \ldots$

3.4 Listing of Available Saltcake Sampling Information $\ldots \ldots \ldots \ldots$

4.1 Analysis of Variance Test for Phase Effect $\ldots \ldots \ldots \ldots \ldots \ldots$

4.2 Least Squares Means for Phase Effect $\ldots \ldots \ldots \ldots \ldots \ldots \ldots \ldots \ldots$

4.3 Tukey HSD Multiple Comparisons Matrix of Pairwise Comparison Probabilities _ . . . 4.4

4.4 Nominal Characteristics of Waste Phases $\ldots \ldots \ldots \ldots \ldots \ldots$

4.5 Analysis of Variance Test for SORWT Group Effect by Phase $\ldots \ldots \ldots \ldots$

4.6 Nominal Composition of REDOX Waste Type Liquid $\ldots \ldots \ldots \ldots \ldots$. . . . . . 4.7

4.7 Moisture Groups for Saltcake Waste $\ldots \ldots \ldots \ldots \ldots \ldots \ldots \ldots \ldots \ldots$

5.1 Estimated Terms in TOC Model Fit $\ldots \ldots \ldots \ldots \ldots \ldots \ldots \ldots \ldots \ldots \ldots \ldots \ldots$

5.2 Highest "Worst $5 \%$ " TOC Estimates in the Liquid Phase $\ldots \ldots \ldots \ldots \ldots$

5.3 Highest "Worst $5 \%$ " TOC Estimates in the Saltcake Phase $\ldots \ldots \ldots \ldots$

5.4 Highest "Worst $5 \%$ " TOC Estimates in the Sludge Phase $\ldots \ldots \ldots \ldots .7$

5.5 Estimated Terms for Moisture Model Fit of the Sludge and Liquid Phases $\ldots \ldots$. . . 5.8

5.6 Estimated Terms for Moisture Model Fit of the Saltcake Phase $\ldots \ldots \ldots \ldots$

5.7 Tanks with the Highest Exceedance Probability for the "Worst 5\%" of Liquid Phase Waste

5.8 Tanks with the Highest Exceedance Probability for the "Worst 5\%" of Saltcake Phase Waste

5.9 Tanks with the Highest Exceedance Probability for the "Worst 5\%" of Sludge Phase Waste 
5.10 Estimate of Organic Carbon Inventory to Tank Farm from B-Plant Consumption . . . .

5.11 Estimate of Organic Carbon Added from PUREX Operation, 1955-1991 $\ldots \ldots \ldots$

5.12 Estimated Distribution of Total Carbon in 149 Single-Shell Tanks

5.13 Estimated Distribution of Total Organic Carbon in 149 Single-Shell Tanks Compared to PUREX and B-Plant Organic Tank Farm Additions . . . . . . . . . . . . . . . .

5.14 Comparison of TOC Estimates for Organic Watchlist Tanks 5.18 


\subsection{Background}

Between 1943 and 1964, 149 single-shell tanks (SSTs) were built for the storage of large quantities of liquid and solid radioactive wastes at the U.S. Department of Energy's Hanford Site. These SSTs, located in tank farms in the 200 West Area and 200 East Area of the Site, contain organic chemicals mixed with nitrate/nitrite salts in potentially hazardous concentrations. Concerns about these potentially hazardous concentrations in the 149 SSTs are being addressed by the Organic Safety Program, led by Westinghouse Hanford Company to develop criteria in identifying SSTs for additional measures including sampling and monitoring.

The TOC and moisture information presented in this report is useful as part of the criteria to identify the SSTs for the additional measures. The actual composition of the organics in the wastes in each of the SSTs is not fully characterized; however, preliminary safety criteria established by the Organic Safety Program (Webb 1995) classify tank waste based on key characteristics, which at a minimum, include the concentration of organic chemicals and the moisture content of the waste.

The Hanford Tank Waste Remediation System is using the Data Quality Objectives (DQO) concept which is a seven-step interative procedure for selecting and analyzing data so that the results are supportable and defensible and can be used by decisionmakers. The DQO process has become one of the accepted support tools used by the DOE and the U.S. Environmental Protection Agency (EPA). The DQO process is specifically used to build a database of characterization data, with an understanding of its confidence level, using process knowledge and laboratory data.

The information provided in this report is a continuation of the initial Pacific Northwest Laboratory study (PNL) ${ }^{(a)}$ completed in April 1994 (Toth et al. 1994) that estimated TOC based on available tank characterization datasets. This initial study used historical TOC laboratory data from WHC characterization datasets. A methodology was developed for estimating the distribution levels of TOC in SSTs using a logarithmic scale and an analysis of variance (ANOVA) technique. The organic constituents of the TRAC code waste inventories were also used to estimate organic constituents in each SST. TRAC organic waste concentrations were compared with laboratory data when available, but no correlation between TRAC estimates and laboratory data was found. Therefore, the TRAC estimates of TOC were deemed inappropriate for further analysis.

This report contains recent work on the method for assessing organic carbon levels based on an ANOVA model of waste phase, waste type, and tank measurements. Moisture levels were also estimated from laboratory characterization data, based on waste phase, and type, and tank surveillance information.

(a) Pacific Northwest Laboratory is operated for the U.S. Department of Energy by Battelle Memorial Institute under Contract DE-AC06-76RLO 1830. 
The SORWT (Sort on Radioactive Waste Type) grouping technique was developed as a methodology to group tanks of similar radioactive waste types (Hill and Simpson 1994). In the SORWT methodology, tanks are fit into families or groups according to the types of wastes admitted to the tanks. The resulting groups can be used to compare tank properties within the same group. In this report, the organic carbon and moisture levels are determined from laboratory measurements of tanks and are grouped according to the waste phase, SORWT groups, and selected tank surveillance information.

Earlier studies were examined as a starting point for this investigation. Klem (1990) ${ }^{(\mathrm{a})}$ estimated values of TOC for 4.7 SSTs, averaging laboratory measurements when multiple data were available. Schulz (1980) reported on results of the organic complexant concentrations for the purpose of understanding the effect of strontium removal in an ion exchange process. The Schulz results indicated high levels of TOC, up to 10\% TOC for tank number.U-106 liquid. Fisher (1990) presented assessments for TOC of selected tanks based on laboratory values.

(a) Letter, M. J. Klem, WHC to R. E. Raymond, WHC, "Total Organic Carbon Concentration of SingleShell Tank Waste," 82316-90-032, dated April 27, 1990. 


\subsection{Scope}

This report provides estimates of TOC and moisture for the SST wastes by using statistical evaluations applied to chemical analysis information gathered from tank reports. The laboratory data are collected from historical tank characterization information and process laboratory reports. The laboratory measurements collected are used to estimate the median TOC level in the tank, the moisture levels, and variation of the estimates within each phase of the tanks. Organic carbon and moisture level assessments of selected tanks without laboratory measurements are also estimated. These estimates are providd by comparing tanks of similar waste phase and waste type.

The laboratory data used in this report were obtained from two types of reports: characterization reports and process laboratory documents. Characterization reports involved full laboratory analysis of core samples and included multiple sample analysis. Laboratory procedures and standards were often documented in the core report characterization studies. The core characterization reports were prepared to provide detailed characterization about the tank in question.

The major objectives of this investigation are listed below:

- Identify additional laboratory analytical data and measurements for SST composite core, auger, and supernatant samples for available TOC data.

- Review laboratory analytical data for SST composite core, auger, and supernatant samples for available moisture data.

- Search for relationships to correlate the TOC and moisture data for SSTs with known parameters related to the tank waste, surveillance data, or historical records.

- From the laboratory analytical data and identified relationships, estimate the TOC content and moisture content of each median tank phase condition and the condition of the worst $5 \%$ of each tank waste phase.

- The condition of the worst $5 \%$ of each tank phase waste is compared to the preliminary safety criteria for organic tanks. Using the tank condition and safety criteria, estimate the probability that the tank phase condition exceeds the preliminary safety criteria.

- Review process history reports for major process contributors of organic constituents to the tank farms and compare those estimates to the total estimate of TOC content for each of the 149 SSTs.

The estimates of TOC concentration in each SST utilize laboratory data reporting TOC measurements as the sample exists in the tank (i.e., wet basis, or with moisture present). In addition to TOC, 
the preliminary safety criteria for organic watchlist tanks include a moisture criteria (Webb et al. 1995). Tanks will be subject to a minimum moisture content of $20 \%$ or more if the TOC criteria are exceeded. Additional measures will be specified for these tanks to maintain safe conditions. The actual limits were developed based upon information from other evaluations (Webb et al. 1995). 


\subsection{Study Approach, Data Sources, and Assumptions}

The purpose of this study is to provide best estimates of TOC and moisture in the 149 SSTs using historical data measurements and statistical evaluation of the historical data measurements. The study must produce realistic and up-to-date results. It should be noted that the results are based on specific assumptions and methodology and that different approaches or assumptions could potentially lead to significantly different results.

\subsection{Study Approach}

The first step in conducting this study was to thoroughly review the earlier investigation "Organic Carbon in Hanford Single-Shell Tank Waste" (Toth et al. 1994). Those results were reexamined in this study to reflect new laboratory data. In addition to the TOC reevaluation, moisture in the tank waste was estimated, and the combined results of TOC and moisture were compared against the preliminary organic safety criteria.

The tank TOC and moisture estimates provided in this report are based on the sampled tank measurement data, tank waste history, and waste phase. About half the SSTs are represented in the database with TOC data, so direct estimates of TOC can be calculated for only half the tanks. For unsampled tanks, a statistical model was constructed that used attributes of tanks with similar characteristics to estimate the tank waste conditions, for both TOC and moisture

A key attribute used to group the tanks to estimate the TOC and moisture is waste phase. The tanks are grouped into three phases: saltcake, sludge, and liquid. Sample measurement information from the tanks permits identification of the phase. Measurements for supernatant, drainable liquid, liquor, filtrate, and slurry are ranked as the liquid phase. Sludge and sludge composite are ranked as sludge phase measurements, and salts and salts/slurries are ranked as saltcake measurements.

The contents of each tank are also divided into the three phases, according to tank surveillance records (Hanlon 1994b). The phase attribute is a key characteristic that is used to estimate the tank waste conditions, for both TOC and moisture, in all tanks. If a tank contains any of the saltcake waste phase, it is designated as a saltcake tank. For example, a tank containing any saltcake is designated as a saltcake tank, and it may or may not contain the other phases.

In addition to waste phase, the TOC and moisture estimates use chemical composition groups that are defined by utilizing the SORWT model. The SORWT model categorizes tanks into groups with waste of similar process history. The premise for the SORWT model is that tanks containing the same waste types will exhibit similar chemical properties. SORWT (previously described in Hill and Simpson 1994) divides the 149 SSTs into 29 groups and 14 ungrouped tanks. The SORWT group model is continually updated based on new process history information (Hill et al. 1995). 
An analysis of variance (ANOVA)-based tank model is applied to produce estimates of TOC and moisture concentrations in all tanks. The ANOVA model uses average or group mean values of the characteristic group to which the tank belongs (phase and SORWT group) to estimate its tank conditions. A very important benefit of the ANOVA-based model is its ability to assign reasonable uncertainties to all produced estimates.

The process waste streams added to the SSTs were added at different times, which could have resulted in unique stratified layers. Unique layers could have been produced as a new waste stream was added because insoluble solids would settle as a layer on top of a previously added layer. If the waste stream contained different TOC concentrations, a potential TOC layer effect could be present in the tank. As a result, measurements of TOC (and moisture) taken from a tank at a particular layer may not be representative of the entire tank contents.

The median concentrations for both TOC and moisture are estimated using the ANOVA model. The TOC estimates are on a wet basis. In addition, the concentrations of the worst $5 \%$ of the waste for both TOC and moisture are estimated. The worst $5 \%$ of the waste is defined to be the $5 \%$ of the waste with the highest TOC concentration (i.e., upper $95 \%$ quantile on TOC) and the $5 \%$ with the lowest moisture concentration (i.e., lower $5 \%$ quantile on moisture). The worst $5 \%$ of the waste is defined on a weight basis, and accounts for the spatial variability of the TOC and moisture concentrations.

For example, given a tank with a mass of 1000 metric tons (MT), the $50 \mathrm{MT}$ of waste containing the highest $Т O C$ is represented as the worst $5 \%$ of the waste TOC, and the driest $50 \mathrm{MT}$ is represented as the worst $5 \%$ of the waste moisture. In the safety analysis, it is assumed the driest and highest TOC concentrations are concurrent.

\subsection{Description of Available Data}

Available data refers to data of three main types. First, there is the chemical and physical characterization that has been performed on laboratory samples for various reasons, including records of compatibility assays and current tank characterization reports. This type of data is referred to as measurement or sampling data.

The second type of data is tank surveillance and waste status reports. These data include the status of the tanks over time, for example, total inventory of waste in the tank measured by surface heights, surface pictures, vertical profile data, or other means; the status of tank ventilation and interim stabilization, and tank temperature and heat load.

The third type of data consists of transaction record data, describing the waste additions and subsequent transfers. Currently, the transaction record data consist of using the SORWT model based on information from Anderson (1990), which is a record of liquid waste transfers and storage in the Hanford 200 West and 200 East Area Tank Farms. 
The tank measurement data were compiled from a variety of sources ranging from letter reports to tank characterization reports. The reports date back to the late 1970s. Because the dataset was compiled from such a variety of sources and spanned such a length of time, some assumptions had to be made. These assumptions and some of the findings from the data-gathering exercise are described in the following sections.

Tank conditions and waste status data (the second type of data) were based on records from Hanlon (1994b). This includes the status of which of the three phases were contained within each tank. A listing of the tanks with each of the three phases is presented in Appendix A. There are 65 tanks containing saltcake, 131 tanks containing sludge, and 129 liquid tanks. The total volume of saltcake, sludge, and liquid is $23 \mathrm{MM}, 12 \mathrm{MM}$ and $36 \mathrm{MM}$ gallons, respectively, indicating the liquid phase comprises the majority of waste.

Tank transaction record data (the third type of data) from Anderson (1990) were the primary source of information to build the SORWT model that categorizes tanks into groups expected to have similar chemical or physical properties. Hill (1994). The SORWT groups used are those currently available, as listed in Appendix D. Updates to the SORWT model groupings are in progress, and these changes will be incorporated into future estimates.

The TOC and moisture measurement data were the primary source for estimating the contents of the tank. The TOC values previously reported in Toth et al. (1994) formed the framework for the dataset presented here. All data are reported as wet basis TOC. The reported values have all been converted to weight percent values (wet) to facilitate analysis. In addition, a portion of the values have been validated by comparison with the reports from which they were taken. Additional datapoints have been included in the TOC dataset as a result of additional core reports becoming available. The values for moisture (weight percent water) have also been validated in a manner similar to that for TOC. Similar to the TOC values, the simplifying assumption was made that data obtained by different analytical methods were comparable. The values for water have also been validated in a manner similar to that for TOC.

When values for TOC and moisture were provided for the same dataset, dry basis TOC values were calculated and are reported in a separate column on the dataset. Tables 3.1 and 3.2 summarize the TOC analytical dataset in Appendix F.

Table 3.1. Distribution of TOC Measurements According to Tank (Total Number of Tanks with TOC Measurements: 78)

\begin{tabular}{|l|c|}
\hline \multicolumn{1}{|c|}{ Number of Measurements } & Number of Tanks \\
\hline More than 10 TOC Measurements & 10 \\
\hline Between 5 and 9 TOC values & 13 \\
\hline Tanks with 5 TOC values & 2 \\
\hline Tanks with 4 TOC values & 7 \\
\hline Tanks with 3 TOC values & 9 \\
\hline Tanks with 2 TOC values & 10 \\
\hline Tanks with 1 TOC value & 27 \\
\hline
\end{tabular}


Table 3.2. Distribution of Measurement Results by Phase

\begin{tabular}{||c|r|r|c|}
\hline $\begin{array}{c}\text { wt\% TOC, Wet Basis } \\
\text { Distribution }\end{array}$ & Liquid & Sludge & Saltcake \\
\hline $0.0-1.0$ & 123 & 188 & 14 \\
\hline $1.0-2.0$ & 10 & 2 & 4 \\
\hline $2.0-3.0$ & 4 & 1 & 2 \\
\hline $3.0-5.0$ & 2 & 3 & 1 \\
\hline$>5.0$ & 3 & 0 & 1 \\
\hline
\end{tabular}

Some reported weight percent values for a variety of analytes were found to be internally inconsistent in their method of calculation, or as a result of measurement technique. This inconsistency had

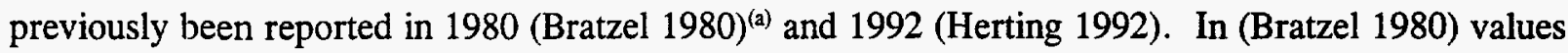
were recalculated from the original data for a limited number of samples. The following order of preference was used in including data for a particular TOC value in the dataset:

1. Weight percent value, reported directly in the reference.

2. Weight percent value calculated from more directly measured values (molar concentration and density, for example.

In some cases, the values from 1 and 2 agreed. When there was discrepancy, the value calculated from 2 was used. This order of preference resulted in keeping data unless there was written evidence that the data point was not credible.

The TOC data reports used in preparing the dataset did not always give the analytical method. As a corollary, many of the reports presented data for more than one waste fraction. The most typical two cases were: 1) supernatant and solid fractions and 2) water soluble and insoluble (acid digest fractions). There were further and other separations included. But for this dataset, all TOC values were included for both the reported water-soluble and insoluble fractions. They are, however, reported as separate data points.

Typically, percent water values were obtained by drying a weighed sample at constant temperature (usually $120^{\circ} \mathrm{C}$ ) until a constant weight was obtained (gravimetric analysis) or by measuring the weight loss over a particular temperature range of a small sample while constantly increasing the temperature (thermogravimetric analysis, TGA). Typically, the weight percent water value for gravimetric analysis is smaller than the TGA value. Additionally, it is obtained from a larger sample size and is thus more representative of the tank waste. Many of the reports gave weight percent water with no method

(a) Letter, D. R. Bratzel, RI, to F. M. Jungfleisch, RI, "Evaluation of Waste Storage Tank Physical and Chemical Characterization Data," 65453-80-2G5, dated September 18, 1980. 
reported. The order of preference for weight percent water values used in this study is: 1) gravimetric analysis, 2) TGA analysis, and 3) weight percent water reported but no method given. Analytical measurement techniques of weight percent water are given in Appendix E.

The breakdown of moisture measurements by tank and phase are presented in Table 3.3. All saltcake sample measurement data used in the statistical analysis are provided in Table 3.4.

Table 3.3. Distribution of Moisture Measurements According to Tank (Total Number of Tanks with Moisture Measurements: 85)

\begin{tabular}{||l|c|c|c|}
\hline \multicolumn{1}{|c|}{ Number of Measurements } & $\begin{array}{c}\text { Tanks with } \\
\text { Sludge } \\
\text { Values }\end{array}$ & $\begin{array}{c}\text { Tanks with } \\
\text { Liquid Values }\end{array}$ & $\begin{array}{c}\text { Tanks with } \\
\text { Saltcake Values }\end{array}$ \\
\hline More than 20 Measurements & 1 & 0 & 0 \\
\hline Between 10 and 19 Measurements & 3 & 0 & 0 \\
\hline Between 5 and 9 Measurements & 0 & 2 & 0 \\
\hline Tanks with 5 Measurements & 0 & 0 & 0 \\
\hline Tanks with 4 Measurements & 0 & 0 & 1 \\
\hline Tanks with 3 Measurements & 2 & 5 & 1 \\
\hline Tanks with 2 Measurements & 9 & 5 & 2 \\
\hline Tanks with 1 Measurement & 20 & 41 & 9 \\
\hline
\end{tabular}

When documentation about a laboratory measurement indicated the data were suspect, the documentation result superseded the original laboratory result. For example, analysis of tank T-104, $10.49 \%$ TOC was determined to be suspect (Richardson 1993) ${ }^{(a)}$ and not included in the dataset. Tank TOC and data not included in the dataset are listed in Appendix $\mathrm{H}$.

\subsection{Approach to Statistical Analysis}

Since the waste within a single tank may exhibit significant variability, it is important to estimate more than "typical" TOC and moisture in a waste phase. Therefore, it is necessary to estimate TOC and moisture concentrations for the "worst" $5 \%$ of the waste in the tank as well as concentrations for "typical" (i.e., median) waste.

(a) Letter, D. C. Richardson, WHC, to R. E. Gerton, RL, "Evaluation of High Total Organic Carbon Results on 1979 Data from Tank 241-TY-106 and 241-TY-T-104," 9253912, dated June 8, 1992. 
Table 3.4. Listing of Available Saltcake Sampling Information

\begin{tabular}{|c|c|c|c|c|c|c|c|}
\hline Tank & Sample ID & $\begin{array}{l}\mathrm{R} \text { or Non-R } \\
\text { Waste Type }\end{array}$ & $\begin{array}{l}\text { SORWT } \\
\text { Group }\end{array}$ & $\begin{array}{c}\text { wt } \% \\
\text { TOC } \mathrm{H}_{2} \mathrm{O} \\
\end{array}$ & $\begin{array}{r}\text { TOC } \\
\text { Wt \% } \\
\end{array}$ & Reference & Ref Date \\
\hline$S 109$ & NA & $\mathbf{R}$ & $\mathrm{I}$ & . & 0.05 & Schulz, 1980 & $1 / 1 / 80$ \\
\hline $\mathrm{SX} 102$ & T-2959 & $\mathbf{R}$ & I & . & 0.82 & I.L. $65453-80-250$ Rockwell 9/3/80 & $9 / 3 / 80$ \\
\hline SX102 & NA & $\mathbf{R}$ & I & . & 0.20 & Schulz, 1980 & $1 / 1 / 80$ \\
\hline $\mathrm{SX} 103$ & 1104 & $\mathbf{R}$ & I & . & & I.L. from JL Starr Rockwell 12/16/7 & $10 / 10 / 77$ \\
\hline $\mathrm{SX} 103$ & NA & $\mathbf{R}$ & $\mathrm{I}$ & . & 0.20 & Schulz, 1980 & $1 / 1 / 80$ \\
\hline U103 & 8793 & Non- $\mathrm{R}$ & VII & . & 3.38 & I.L. from JL Starr 12/14/77 Rockwell & $8 / 15 / 77$ \\
\hline $\mathrm{TX} 118$ & RAT-TX118-6 & Non-R & XXII & . & 1.06 & 65453-81-331 Rockwell 10/16/81 & $10 / 16 / 81$ \\
\hline TY102 & RAT-TY102-1 & Non-R & II & 58.000 & 0.24 & 65124-80-077 Rockwell 2/1/80 & $2 / 1 / 80$ \\
\hline BX107 & RAT-BX107-2 & Non- $\mathrm{R}$ & $\mathrm{XI}$ & 53.700 & 0.07 & 65453-80-265 Rockwell 9/18/80 & $9 / 18 / 80$ \\
\hline BX 110 & NA & Non-R & XXIV & 51.900 & & 65453-80-265 Rockwell & $9 / 18 / 80$ \\
\hline A101 & RAT-A 101-4A & Non-R & $\mathrm{IX}$ & 42.370 & 0.58 & I.L. 65453-80-337 Rockwell & $11 / 10 / 80$ \\
\hline U111 & RAT-U111-2 & Non-R & VII & 39.120 & 0.52 & 65453-80-273 Rockwell 9/23/80 & $9 / 23 / 80$ \\
\hline TY101 & NA & Non- $R$ & $\mathrm{XXXG}$ & 37.270 & & $\begin{array}{l}\text { 65453-80-265 Rockwell 9/18/80, Table } \\
7.0 .1\end{array}$ & $9 / 18 / 80$ \\
\hline $\mathrm{A} 101$ & RAT-A101-5A & Non-R & IX & 34.190 & 0.84 & I.L. 65453-80-337 Rockwell Int. & $11 / 11 / 80$ \\
\hline U111 & RAT-U111-3 & Non-R & VII & 33.620 & 0.54 & 65453-80-273 Rockwell 9/23/80 & $9 / 23 / 80$ \\
\hline $\mathrm{U} 105$ & RAT-U105-3 & $\mathrm{R}$ & $\mathrm{X}$ & 20.800 & 2.80 & 60120-78-125 Rockwell 12/4/78 & $12 / 4 / 78$ \\
\hline S111 & $1009-\mathrm{C}$ & $\mathbf{R}$ & I & 18.100 & 2.34 & 1.L. 60120-78-087 Rockwell 8/25/75 & $8 / 25 / 78$ \\
\hline S111 & $1003 / 1004-\mathrm{C}$ & $\mathrm{R}$ & I & 17.400 & 1.54 & I.L. 60120-78-087 Rockwell 8/25/75 & $8 / 25 / 78$ \\
\hline BY104 & riser5/auger & Non-R & III & 17.000 & 0.60 & WHC-SD-WM-RPT-068 REV 0 & $5 / 3 / 93$ \\
\hline BY104 & riser5/auger & Non-R & III & 17.000 & 0.90 & WHC-SD-WM-RPT-068 REV 0 & $5 / 1 / 93$ \\
\hline BY104 & riser 10b/auger & Non-R & III & 15.000 & 1.10 & WHC-SD-WM-RPT-068 REV 0 & $5 / 2 / 93$ \\
\hline BY104 & riser $10 \mathrm{~b} /$ auger & Non-R & III & 15.000 & 1.10 & WHC-SD-WM-RPT-068 REV 0 & $5 / 4 / 93$ \\
\hline SX102 & RAT-SX-102 & $\mathrm{R}$ & I & 13.900 & & $\begin{array}{l}\text { I.L. ARHC From J.S. Buckingham to R.E. } \\
\text { Van der Cook, March } 18,1976\end{array}$ & $3 / 18 / 76$ \\
\hline SX105 & RAT-SX-105 & $\mathbf{R}$ & I & 13.000 & & $\begin{array}{l}\text { Internal Memo to D.C. Lini, Engineering } \\
\text { Assistance Waste Concentration }\end{array}$ & $2 / 1 / 77$ \\
\hline SX104 & $\mathrm{NA}$ & $\mathrm{R}$ & I & 11.400 & & $\begin{array}{l}\text { Internal Memo to D.C. Lini, Engineering } \\
\text { Assistance Waste Concentration }\end{array}$ & $3 / 1 / 77$ \\
\hline S111 & $1001-\mathrm{C}$ & $\mathrm{R}$ & 1 & 10.700 & 0.10 & I.L. 60120-78-087 Rockwell 8/25/75 & $8 / 25 / 78$ \\
\hline SX107 & 1345 & $\mathbf{R}$ & VI & 10.000 & & $\begin{array}{l}\text { Internal Memo to D.C. Lini, Engineering } \\
\text { Assistance Waste Concentration }\end{array}$ & $1 / 29 / 77$ \\
\hline
\end{tabular}


The Organic Safety Program has established preliminary safety criteria that address the hazard of a propagating chemical reaction in the tanks. The preliminary safety criteria are based on the TOC concentration of the waste and the moisture content. The criteria are based on conservative experimental results from sodium acetate properties and are fully explained in (Webb et al. 1995). The preliminary safety criteria are:

$$
\text { wt } \% \text { TOC }=4.5+0.17 *(w t \% \text { Moisture })
$$

In addition, the unsafe region is bound by moisture $<20 \%$. Using the above equation, the safety cri terion is defined by the two points, $\left(\mathrm{H}_{2} \mathrm{O}=0, \mathrm{TOC}=4.5 \%\right.$, and $\mathrm{H}_{2} \mathrm{O}=20 \%$, TOC $\left.=7.9 \%\right)$. The safety criterion is assumed to be linear between the two points. The wt\% Moisture represents free (non-hydrated) water.

The safety criteria can be applied to any available TOC, moisture estimates to determine whether or not a particular tank is safe. However, such a calculation does not properly take uncertainty in the (TOC, moisture) estimates into account. The available estimates may fall below the safety threshold but, because of uncertainty, have a substantial chance of actually being above the threshold. It is therefore important to calculate the "exceedance probability" associated with any (TOC, moisture) estimate. The exceedance probability is defined to be the probability that a particular tank exceeds the safety criteria, given the actual (TOC, moisture) estimate available.

This study is concerned with the exceedance probability associated with the worst $5 \%$ of the waste. In this study, the term "exceedance probability" refers to the probability that the worst $5 \%$ of the waste is in the unsafe region identified in Figure 5.4 (Section 5.4).

Since data are not available on every tank, it is not possible to directly estimate what is in each tank. To produce the desired estimates of TOC and moisture, this study utilizes tank grouping models, which divide the Hanford tanks into groups of "similar" tanks. An effective grouping is one that produces homogeneous groups and therefore allows the group average (or some other group statistic) to be used as a reasonable estimate for unsampled tanks.

In order for this grouping strategy to be effective, data must be present for most of the defined groups. This places an important constraint on the tank groupings that will be useful for this study. The most severe problem in this regard occurs with the saltcake estimates; only 20 saltcake measurements exist, so the tank grouping model used for saltcake must be simple.

The information that is used to define the groupings in this study includes:

- SORWT groupings (for TOC and moisture)

- Tank ventilation (for moisture)

- Pump status: Has the tank been jet pumped? (for moisture) 
The tank grouping models employed in this study are actually ANOVA models. Once such an ANOVA model is specified, it is possible to use standard statistical algorithms to estimate the contents of each tank as well as the uncertainty of the estimate. An ANOVA model will provide a fairly complete description of the distribution of TOC (or moisture) within the tank, between tanks, and between the postulated tank groupings. With this information, it possible to describe the (TOC, moisture) content of typical waste in a tank, as well as calculate the (TOC, moisture) content of the worst $5 \%$ of the waste.

The ability of ANOVA models to produce such a detailed description of the waste and also to assign uncertainties to the estimates is the principal reason for choosing ANOVA analysis over simple averaging methodologies.

\subsubsection{ANOVA Model for TOC}

The TOC in each of the three waste phases (liquid, sludge, saltcake) is described by an ANOVA model of the form:

$$
\log \left(\mathrm{TOC}_{\mathrm{ijk}}\right)=\mu+\mathrm{G}_{\mathrm{i}}+\mathrm{T}_{\mathrm{ij}}+\mathrm{E}_{\mathrm{ijk}}
$$

where the indices $\mathrm{i}$ identifies a particular SORWT group, ij a particular tank, and ijk a particular sample from the tank. Thus, the term $\mu$ represents the mean value for $\log (\mathrm{TOC})$ in all Hanford tanks, the term $G_{i}$ represents the deviation of SORWT group $i$ from that grand mean, the term $T_{i j}$ represents the deviation of tank ij from the mean group value, and $E_{\mathrm{ijk}}$ represents the deviation of sample ijk from the tank mean value. Each of the three terms $G_{i}, T_{i j}$, and $E_{i j k}$ is assumed to be normally distributed with a variance of $\sigma_{\mathrm{G}}^{2}, \sigma_{\mathrm{T}}^{2}$, and $\sigma_{\mathrm{E}}^{2}$, respectively.

The TOC values are logged in order to make the three terms conform to a normal distribution. Without logging the data, these terms are not normally distributed. Section 4.1 discusses this issue in greater depth and provides distributional plots that justify the use of the log transformation.

Given a set of data, the ANOVA procedure is capable of estimating the unknown parameters in the model (i.e., $\mu, G_{i}, \sigma_{G}^{2}$, etc.). These parameters can be combined to produce tank estimates. For example, to estimate the median TOC value ${ }^{(a)}$ for a tank, use the quantity

$$
\mu+\mathrm{G}_{\mathrm{i}}+\mathrm{T}_{\mathrm{ij}}
$$

If good sampling data existed for the tank, the term $T_{i j}$ would be non-zero and the quantity

$$
\mu+\mathrm{G}_{\mathrm{i}}+\mathrm{T}_{\mathrm{ij}}
$$

(a) Since the TOC values are converted to the lognormal form, the log-mean and median are the same. 
would be equivalent to the average of the sampling data. When no data exist for the tank of interest,

$$
\mathrm{T}_{\mathrm{ij}}=0
$$

and the estimate for the unsampled tank reduces to the SORWT group estimate,

$$
\mu+\mathrm{G}_{\mathrm{i}}
$$

ANOVA also produces uncertainties for these estimates in the form of a mean squared error (MSE). When the TOC for an unsampled tank is estimated, its mean squared error is larger than the MSE associated with a sampled tank.

\subsubsection{ANOVA Models for Moisture}

An attempt was made to use the same ANOVA model developed for TOC. However, an analysis of the resulting fits indicated problems that required alterations to the model.

Two principal problems existed with the moisture measurements:

1. A distributional analysis of the model terms indicated that a log-normal relationship was not appropriate for the sludge or liquid phases.

2. An ANOVA model utilizing the SORWT grouping was inadequate for the saltcake phase.

Groups defined by two variables 1) the ventilation state of the tank (active, passive) and 2) the pump status of the tank (jet-pumped, not jet-pumped) were found to have a very strong effect on measured moisture in the tank. Consequently, they were used to define groups in saltcake.

Because only 20 saltcake moisture measurements exist, it is not be useful to employ the SORWT grouping, which contains 29 groups plus 14 solidary tanks. For saltcake, the SORWT groupings were simplified to two (REDOX waste and non-REDOX waste). This binary grouping segregates waste into that which should not have much water of hydration (REDOX waste) and that which should (non-REDOX waste).

Thus, the ANOVA model fit to sludge and liquid phase moisture measurements has the form:

$$
M_{i j k}=\mu+G_{i}+T_{i j}+E_{i j k}
$$

where the indices are defined exactly as in the TOC model: i represents a SORWT group, ij a tank, and ijk a sample from the tank. 
$\mu=$ mean moisture value of all moisture data for the sludge or liquid phase (model-calculated value), percent.

$\mu+\mathrm{G}_{\mathrm{i}}=$ mean moisture value for SORWT Group $\mathrm{i}$, model calculated value, percent.

$E_{\mathrm{ijk}}=$ moisture residual variability (includes sample location variability (core, riser) and measurement technique variability.

The moisture ANOVA model described in the above equation is a random effects model. That is, the terms $\mu$, and $\mathrm{G}_{\mathrm{i}}$ are assumed to be normally distributed random variables. The assumption that these terms are random effects provides enough information to allow us to estimate moisture in tanks with no measurements. The random effects model used to assess the moisture in each tank utilizes the characteristic information known about the tanks. The tank moisture estimates tend to be shrunk towards the phase means. The moisture ANOVA model estimated the standard deviation components using the restricted maximum likelihood (REML) technique (Corbeil and Searle 1976). This algorithm was the basis for the Splus computations.

The ANOVA model for saltcake utilizes a different grouping methodology. This methodology utilizes the variables ventilation $V_{i}$, pump-status $P_{j}$, and waste type $R_{k}$ and has the form:

$$
\log \left(M_{i j k}\right)=\mu+V_{i}+P_{j}+R_{k}+T_{i j k}+E_{i j k}
$$

A logarithmic transformation is necessary to produce normally-distributed terms for saltcake. Also, the log transformation constrains all estimates to positive values. Without such a constraint, moisture estimates for the worst $5 \%$ of the waste could sometimes be negative.

In this model, the index $i$ indicates whether tank ijk is ventilated, $j$ indicates whether it has been jetpumped, and $\mathrm{k}$ indicates whether it contains principally REDOX waste. Utilization of these three binary variables for tank grouping produces eight groups. It so happens that some of the groups lack measurements. For example, the group of actively ventilated, jet-pumped, REDOX-waste tanks is lacking any measurements. Nevertheless, the model is capable of making a reasonable prediction for this group because the effects of the grouping variables are assumed to be linear (on the log scale).

The proposed saltcake model is reasonable and does fit the existing data quite well. However, this model can be considered the weakest part of the present analysis. If more saltcake measurements are taken, it is quite possible that inadequacies with this model would become apparent. The saltcake predictions are the set of measurements most likely to change significantly when new data are collected. Even though the ANOVA models produce the most reasonable description of the current data, there is always the possibility that future data may reveal inadequacies with the present models. 


\subsection{Study Assumptions}

For ease of reference, the assumptions used in this evaluation are presented below:

1. All TOC and moisture data, each laboratory measurement, are weighted equally.

2. All TOC and moisture laboratory data available are used in this study except where conflicting information indicates the data are implausible. All laboratory measurements resulting from different pretreatment methods are also included in the dataset.

3. Waste phase of the data is assumed to belong to one of the following three phases: saltcake, liquid or sludge. Liquid waste includes supernatant and interstitial liquid. Saltcake is formed from thermal evaporation and subsequent crystallization. Sludge is formed from the waste settling process. The waste phases are significantly different from each other.

4. The TOC data are represented by a lognormal distribution, and making a logarithmic transformation of the data results in a normally distributed dataset.

5. The SSTs can be grouped together based on information pertaining to the waste type in the tank. A qualitative grouping methodology based on significant waste types and processing history can used to distinguish tanks with respect to TOC and moisture. The SORWT model accurately predicts groups of tanks.

6. The ANOVA technique is used to calculate the TOC and moisture estimates, conditions of the worst $5 \%$ of the waste, and exceedance probabilities.

7. TOC and moisture are independently estimated. It is assumed the high TOC regions of the waste are highly correlated to the low moisture regions.

8. The maximum level of TOC in a tank waste is $25 \%$. This is equal to $85 \mathrm{wt} \%$ sodium acetate.

The statistical assumptions can be tested by preparing histogram plots of the data, and by conducting ANOVA-test evaluations. This is discussed in the next section. For example, the null hypothesis tested would be that the deviations between the mean concentrations of the phases or SORWT groups were due to only random variability within the entire dataset. If the null hypothesis was proved valid, then no phase or group effects were present and the method described above would be discredited. However, if the null hypothesis was proved incorrect, then the converse is true and the data would support the presence of phase and group effects and validate the methodology, 


\subsection{Evaluation of SSTs Using ANOVA Models}

The objective of the statistical data analysis of TOC and moisture data is to provide estimates of concentrations of each in all 149 Hanford SSTs individually. In addition, the uncertainty surrounding these TOC and moisture estimates and the probability of exceeding the watchlist threshold concentration is equally important and is also presented.

\subsection{Appropriate Distribution of TOC Data}

The statistical tests and probability of exceeding threshold analyses are considered valid only for normally distributed datasets. A histogram of the TOC data in units of $\mu \mathrm{g} / \mathrm{g}$ was prepared from the entire dataset (Figure 4.1). Notice that this distribution of the data is heavily skewed to the left because the vast majority of the data is relatively near zero. Because of the skewedness of the data, the statistical tests and probability of exceedance would not be considered valid for this dataset. A second histogram was generated from a $\log$ transformation of the TOC data (Figure 4.2). Notice that the log transformed data appears normally distributed. This transformation is reported in detail in Toth et al. (1994). Also, similar observations have been made for the data within any particular phase.

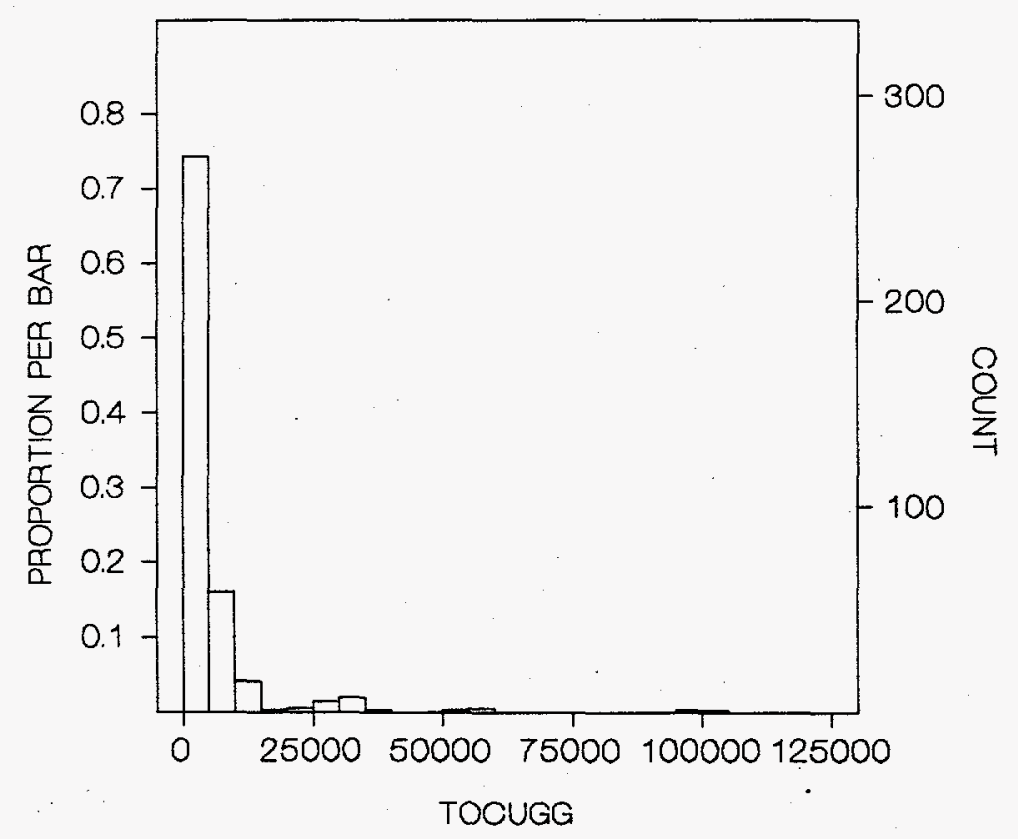

Figure 4.1. Histogram of Entire TOC Dataset 


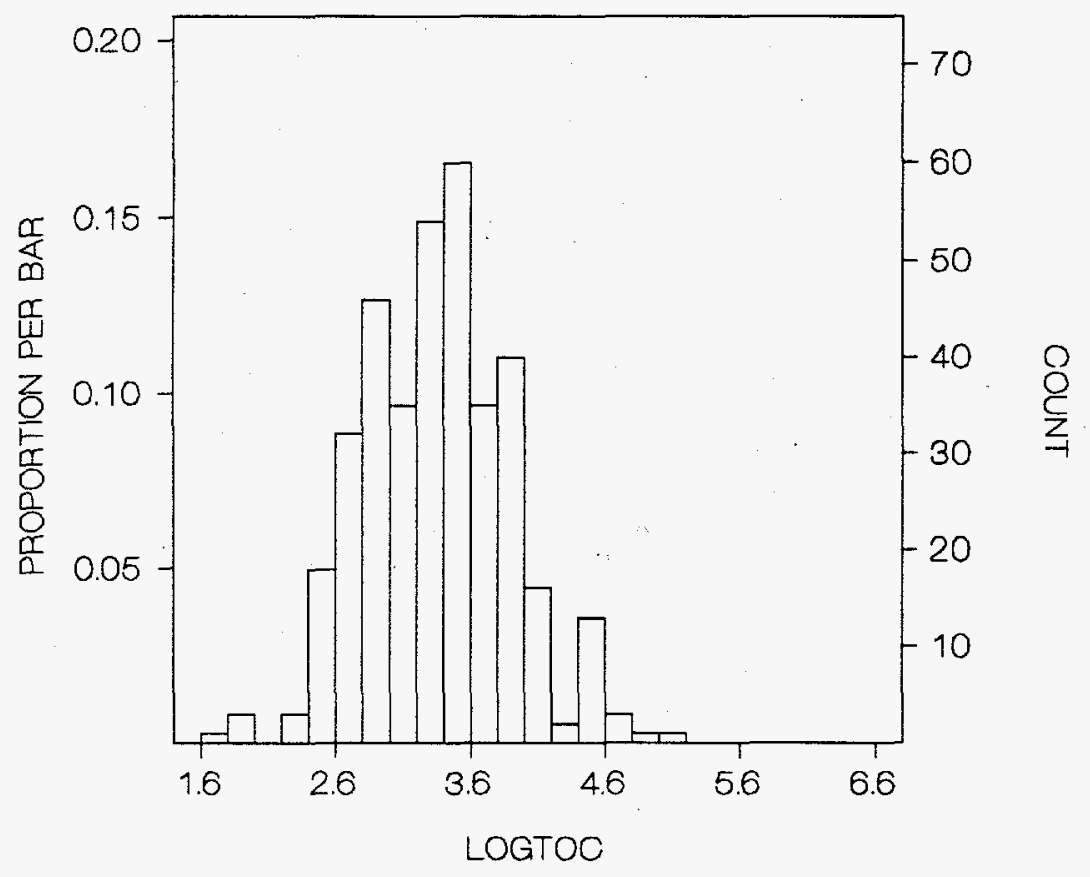

Figure 4.2. Histogram of Entire TOC Dataset, Logarithmic Transformation

\subsection{Importance of Waste Phase}

Another assumption tested was the presence of a waste phases effect. The ANOVA test used is a quantitative method to test the significance of the effect a particular treatment has on the response or dependent variable. In this application, the treatment being studied is waste phase and the dependent variable is the $\log$ of TOC concentration. An ANOVA will test whether the mean concentration of a particular phase is statistically significantly different from the mean concentration of other phases.

The ANOVA test was performed for phase (liquid, saltcake, and sludge) using the general linear model of the SYSTAT for Windows ${ }^{(a)}$ statistical data analysis software package.

The null hypothesis tested was that there were no differences between waste phases. The ANOVA-test table provides two estimates for the variance, one between phases and one within phases. If the null hypothesis is accurate, then the estimate for the between-phases variance should be similar in magnitude to the within-phase estimate of the variance. Conversely, if the between-phase estimate of the variance is significantly greater than the within-phase estimate, then the null hypothesis would be untenable and some of the between-phase variation must be caused by real differences between treatment groups. The output reports generated by the statistical software for this analysis are shown in Appendix B. The first page of

(a) SYSTAT for Windows is a registered trademark of SYSTAT, Inc. 
Table 4.1. Analysis of Variance Test for Phase Effect

\begin{tabular}{|c|c|c|c|c|c|}
\hline Source & Sum-of-Squares & DF & Mean-Square & F-Ratio & P \\
\hline Phase & 18.87 & 2 & 9.435 & 40.575 & 0.000 \\
\hline Error & 82.549 & 355 & 0.233 & & \\
\hline
\end{tabular}

Table 4.2. Least Squares Means for Phase Effect

\begin{tabular}{|l|c|c|c|}
\hline & LS Mean & SE & N \\
\hline Liquid & 3.569 & 0.04 & 142 \\
\hline Saltcake & 3.771 & 0.103 & 22 \\
\hline Sludge & 3.145 & 0.035 & 194 \\
\hline
\end{tabular}

Appendix B represents the ANOVA test for phase. The ANOVA table is also illustrated by Tables 4.1 and 4.2. As shown in these two tables, the items included in the ANOVA table are the sum of the squares, degrees of freedom (DF), and the mean sum of the squares (Mean-Square). The least square (LS) means, standard error (SE), and number of observations for each phase are also presented. Each of these items was calculated for treatments and error. The treatment calculations are for variance between individual treatments, which in this study represents different waste phases (PHASE). The error components denote the variance within the individual treatments or waste phases. The mean sum of the squares is the quotient of the sum of the squares and the number of degrees of freedom.

The F-Ratio is defined as the ratio of the between-treatment variance (mean sum of the squares) and the within-treatment variance. (This value is also reported in the ANOVA table.) This ratio should follow an $\mathrm{F}$ distribution for the appropriate numbers of degrees of freedom. The significance of the F-Ratio is called a $P$-value and can be determined from the relevant $F$ distribution. The significance is the fractional probability of the F-Test ratio happening due only to random chance. The benchmark probabilities typically used to test the significance of differences between means is $5 \%$ and $1 \%$, which correspond to significance of 0.05 and 0.01 . For the purposes of the TOC study, the $5 \%$ benchmark was selected. If the significance is greater than the benchmarks, then the differences between treatment means can be explained by random chance. If the significance is below the benchmarks, then the discrepancies between treatment means cannot be explained by random chance, and real differences exist between the phases. The P-Value is included in Table 4.1.

As shown in Table 4.1, the effect of phase has a significance well below the benchmark 5\% level. In fact, it has a significance below $0.1 \%$. The ANOVA indicates there is virtually no probability that the differences between the means of the waste phases are due only to random chance. Therefore, the null hypothesis is invalid and the data strongly supports the premise that waste phases should be analyzed separately. This is supported by organic concentration mechanism investigations (Gerber 1994). 
Since a significant phase effect was observed, a Tukey pairwise comparison was performed to identify which phases were significantly different from one another. This comparison can be found on the bottom portion of the first page of Appendix B. The Tukey pairwise comparison first generates a matrix of pairwise mean differences. These are the differences between the mean concentration of a pair of phases. The routine then compares this difference to the mean square error from the ANOVA table and calculates a P-value (probability) that the difference between the mean concentration of any two phases is due to random chance. These P-values are presented in Table 4.3.

Table 4.3. Tukey Multiple Comparisons Matrix of Pairwise Comparison Probabilities

\begin{tabular}{||l|c|c|c||}
\hline & Liquid & Saltcake & Sludge \\
\hline Liquid & 1.000 & & \\
\hline Saltcake & 0.161 & 1.000 & \\
\hline Sludge & 0.000 & 0.000 & 1.000 \\
\hline
\end{tabular}

The test for significance is the 0.000 probability in the column for liquid versus sludge, and saltcake versus sludge. The Tukey pairwise comparison of TOC data indicates that TOC in sludge is significantly different from liquid and saltcake TOC, with comparison probabilities of 0.000 . However, the difference between saltcake TOC and liquid TOC cannot be called statistically significant with a pairwise comparison probability of 0.161 . This is probably due to the small number (20) of observations for saltcake. For the purposes of this model, the three phases were considered independent from one another.

\subsection{Nominal Characteristics of Waste Phase}

The nominal characteristics of each phase were determined. The laboratory data for the tank samples are presented in Appendix F. Section B.2 of Appendix B presents descriptive statistics of each waste phase for TOC in units of $\mu \mathrm{g} / \mathrm{g}$ (TOCUGG), log of TOC (LOGTOC), density in $\mathrm{g} / \mathrm{mL}$ (GML), and weight percent water $(\mathrm{H} 2 \mathrm{O})$. Section B.3 presents the $95 \%$ confidence intervals for each phase. This information has been summarized below in Table 4.4. It is important to note that the mean and confidence intervals for TOC were calculated from the log transformed data and converted back to units of $\mu \mathrm{g} / \mathrm{g}$.

From Table 4.4, it can be seen that saltcake is expected to have the highest concentration of TOC relative to the other phases and that sludge is expected to have the lowest. The $95 \%$ confidence intervals around the liquid and sludge data are generally approaching the means value. The saltcake confidence intervals are larger due to the small number of observations available on that waste phase. Saltcake also appears to be the most dense phase and contains the least amount of water. Because there are only 22 TOC measurements and 18 moisture measurements for saltcake, it appears that saltcake is both the worst material from a safety standpoint and the least known. The indication that saltcake contains the highest organic level suggests a redistribution of the organic form the liquid phase. The saltcake data, for both moisture and TOC, are shown in Table 4.4. Liquids are the lightest phase and contain the greatest amount of water. 
The confidence intervals shown in Table 4.4 are a result of statistical analysis. It is possible, due to data spread, that overlap of phases will occur. For example, the lower limit moisture estimates for liquid overlap with the upper limit moisture estimates for saltcake.

Table 4.4. Nominal Characteristics of Waste Phases

\begin{tabular}{||c|c|c|c|c|c||}
\hline \multirow{2}{*}{$\begin{array}{c}\text { Waste } \\
\text { Characteristic }\end{array}$} & $\begin{array}{c}\text { Waste } \\
\text { Phase }\end{array}$ & $\begin{array}{c}\text { Number of } \\
\text { Samples }\end{array}$ & $\begin{array}{c}\text { Lower 95\% } \\
\text { Confidence } \\
\text { Interval }\end{array}$ & $\begin{array}{c}\text { Mean } \\
\text { Value }\end{array}$ & $\begin{array}{c}\text { Upper 95\% } \\
\text { Confidence } \\
\text { Interval }\end{array}$ \\
\hline \multirow{3}{*}{ TOC, $\mu \mathrm{g} / \mathrm{g}$} & Liquid & 143 & 3,106 & 3,775 & 4,588 \\
\cline { 2 - 7 } & Saltcake & 20 & 3,161 & 5,296 & 8,870 \\
\cline { 2 - 7 } & Sludge & 202 & 1,096 & 1,294 & 1,527 \\
\hline \multirow{3}{*}{ Wt \% H2O } & Liquid & 78 & 40.28 & 66.3 & 87.3 \\
\cline { 2 - 7 } & Saltcake & 20 & 0 & 25.99 & 50.89 \\
\cline { 2 - 7 } & Sludge & 135 & 18.65 & 44.21 & 69.77 \\
\hline \multirow{3}{*}{ Density, (g/mL) } & Liquid & 43 & 1.31 & 1.37 & 1.43 \\
\cline { 2 - 7 } & Saltcake & 8 & 1.43 & 1.64 & 1.84 \\
\cline { 2 - 7 } & Density & 77 & 1.40 & 1.45 & 1.50 \\
\hline
\end{tabular}

\subsection{Significance of SORWT Grouping}

The next assumption to be tested is the presence of groups of tanks as predicted by the SORWT model. A description of the SORWT groups is shown on Appendix M. Although SORWT groups have been shown to be significant in Hill and Simpson (1994) and Hill et al. (1995), the present dataset must also be tested. Since waste phase has already been shown to be important, the presence of SORWT groups will be tested for each phase individually using the general linear model of the SYSTAT for Windows statistical data analysis software package. If a significant grouping effect was observed, then a Tukey pairwise comparison was also made for each analyte to investigate which groups were significantly different from one another. The results for the ANOVA of SORWT groups for each of the phases are similar in design to the ANOVA results described above. The results have been summarized in Table 4.5.

The ANOVA test summary table indicates that there is not a significant grouping effect for saltcakes but a very strong grouping effect for both liquids and sludge because of the low "P" values. 
Table 4.5. Analysis of Variance Test for SORWT Group Effect by Phase

\begin{tabular}{||c|c|c|c|c|c||}
\hline \multicolumn{1}{|c|}{ Source } & Sum-Square & DF & Mean-Square & F-Ratio & P \\
\hline Saltcake & & & & & \\
\hline SORWT & 1.946 & 7 & 0.278 & 0.898 & 0.534 \\
\hline Error & 4.330 & 14 & 0.309 & & \\
\hline Liquid & & & & & \\
\hline SORWT & 14.155 & 25 & 0.566 & 3.147 & 0.000 \\
\hline Error & 20.873 & 116 & 0.180 & & \\
\hline Sludge & & & & & \\
\hline SORWT & 19.890 & 20 & 0.994 & 8.056 & 0.000 \\
\hline Error & 21.356 & 173 & 0.123 & & \\
\hline
\end{tabular}

\subsection{Nominal Composition of SORWT Groups}

The nominal characteristics of each SORWT group by phase were determined. Appendix C presents descriptive statistics of each waste phase for TOC in the same units as Appendix B. Appendix C is divided into two sections. Section C.1 presents the descriptive statistics of each SORWT group with data for liquid sarnples. Section C. 2 presents the same information for sludge samples.

\subsection{Effect of Jet-Pumping, Ventilation, and Waste Type on Saltcake Moisture}

Moisture estimates for saltcakes are fundamentally different than for sludge since saltcake does not retain moisture as effectively as sludge. Due to the low number of saltcake moisture observations (20) and the number of SORWT groups, it is not useful to use the SORWT group to estimate saltcake moisture. In lieu of the SORWT group, a waste category based on the SORWT group was developed. Each SORWT group was placed into a category of waste depending upon if REDOX waste is the primary waste type in the tank. The REDOX waste is the high-level radioactive waste component from the REDOX process operated at Hanford. The composition varied, but the following is considered the nominal composition for REDOX wastes, as shown on Table 4.6. Saltcakes and sludges resulting from this waste are also designated as REDOX wastes (Anderson 1990). Characterisitics of REDOX waste include very high nitrate and sodium, high aluminum, and low phosphate and low bismuth concentrations (Hill and Simpson 1994) SORWT Groups I, VI, X, XVI, and XXIX are REDOX SORWT groups, based on Hill and Simpson (1994). Non-REDOX or non-R waste is characteristic of all other saltcakes. 
Table 4.6. Nominal Composition of REDOX Waste Type, Liquid

\begin{tabular}{||l|l|}
\hline $\mathrm{NaAlO}_{2}$ & $1.2 \mathrm{M}$ \\
\hline $\mathrm{NaO} 4$ & $0.7 \mathrm{M}$ \\
\hline $\mathrm{NaNO}_{3}$ & $4.8 \mathrm{M}$ \\
\hline $\mathrm{Na}_{2} \mathrm{CrO}_{7}$ & $0.07 \mathrm{M}$ \\
\hline $\mathrm{Cr}(\mathrm{O} 4)_{3}$ & $0.04 \mathrm{M}$ \\
\hline $\mathrm{Na}_{2}\left(\mathrm{SO}_{4}\right.$ & $0.03 \mathrm{M}$ \\
\hline $\mathrm{Fe}(\mathrm{OH})_{4}$ & $0.02 \mathrm{M}$ \\
\hline $\mathrm{U}$ & $0.05 \%$ \\
\hline $\mathrm{Pu}$ & $0.04 \%$ \\
\hline density & $1.3 \mathrm{~g} / 1$ \\
\hline \hline
\end{tabular}

Further grouping of saltcake depending on surveillance status is included. Jet pumping and tank ventilation status was included in the grouping. Jet pumping refers to a tank draining technique whereby liquid is pumped from the saltwell of tank. Unlike supernatant pumping, interstitial liquid is removed from the tank during jet-pumping. Tank ventilation may be active or passive. Active ventilation indicates the installation of an operating exhauster on the tank as recorded by Hanlon (1994b).

Figure 4.3 displays the results of the saltcake moisture categories. Each saltcake waste is grouped into one of eight moisture groups. The eight moisture groups are listed in Table 4.7. From the available data for four moisture groups, it can be seen that the saltcake data from the group belonging to passively ventilated tanks, not jet-pumped, with non-REDOX waste, contains the highest moisture. Figure 4.3 indicates the variability of the moisture is directly proportional to its magnitude, suggesting a lognormal distribution for this model. 


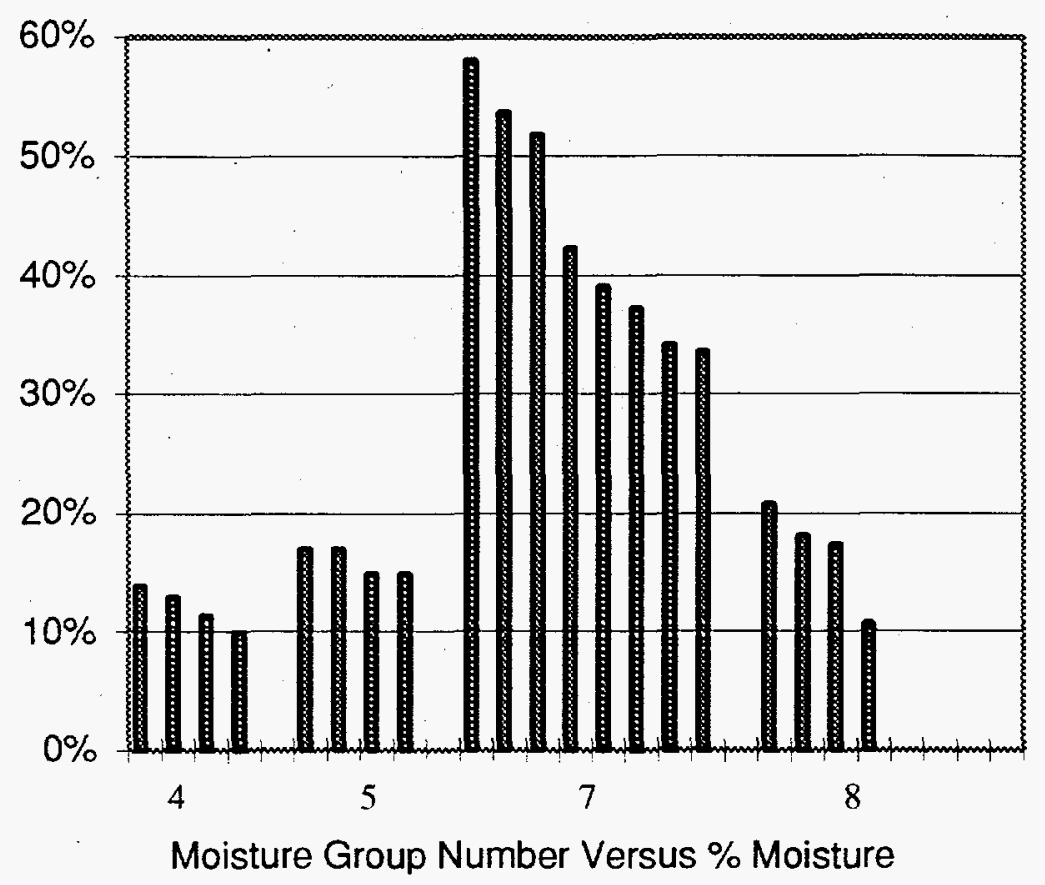

Figure 4.3. Saltcake Moisture Data Grouped According to Categories Shown in Table 4.6

Table 4.7. Moisture Groups for Saltcake Waste

\begin{tabular}{||l|c|c|c|c||}
\hline & \multicolumn{3}{|c|}{ Description of Saltcake Waste } & \\
\hline & & & & Group \\
Data Available & Ventilation & Waste rype & Pump Status & Number \\
\hline Not Available & Active & Non-REDOX & Jet Pumped & 1 \\
\hline Not Available & Active & REDOX & Jet Pumped & 2 \\
\hline Not Available & Active & Non-REDOX & Not Pumped & 3 \\
\hline Available & Active & REDOX & Not Pumped & 4 \\
\hline Available & Passive & Non-REDOX & Jet Pumped & 5 \\
\hline Not Available & Passive & REDOX & Jet Pumped & 6 \\
\hline Available & Passive & Non REDOX & Not Pumped & 7 \\
\hline Available & Passive & REDOX & Not Pumped & 8 \\
\hline
\end{tabular}

\subsection{Comparison of TOC Measurement Data}

As described in Section 4.3, the nominal characeristics of the waste phase are important in determining the TOC values for the tanks. Since TOC measurements of samples span a period of 1978 to 1994, it 
is worthwhile to illustrate how the TOC measurements vary with time, across a given a phase. Sufficient TOC data on selected tanks for the liquid phase is available to permit an illustration of the consistency of TOC measurement data for a given tank, for liquid measurements. Ideally, the measurements would be compared that have been taken at identical sample locations within a tank waste. However, sufficient sample location data is not adequately available to compare identical sample locations over time. Therefore, variations in measurement data for samples include spatial variation of TOC within a tank, as well as analytic technique measurement variation, TOC degradation effects, plus any other residual error terms. Sufficient measurement data for TOC in SST liquids that span a significant interval of time, more than five years, is available for four SSTs: A-103, C-103, S-107, and T-107. Sufficient TOC data for the saltcake and sludge phase is not available for similar comparison as is conducted for liquids.

The results of the TOC measurements of liquid samples are shown in Figure 4.4. Single-shell tank T-107 consistently reported lower TOC measurements than the other three single-shell tanks by almost an order of magnitude. The reported measurements for liquid samples, on the four SSTs with available data that span a significant interval of time, indicate that within-tank measurements of \%TOC are generally consistent over time, 1978-1994. 


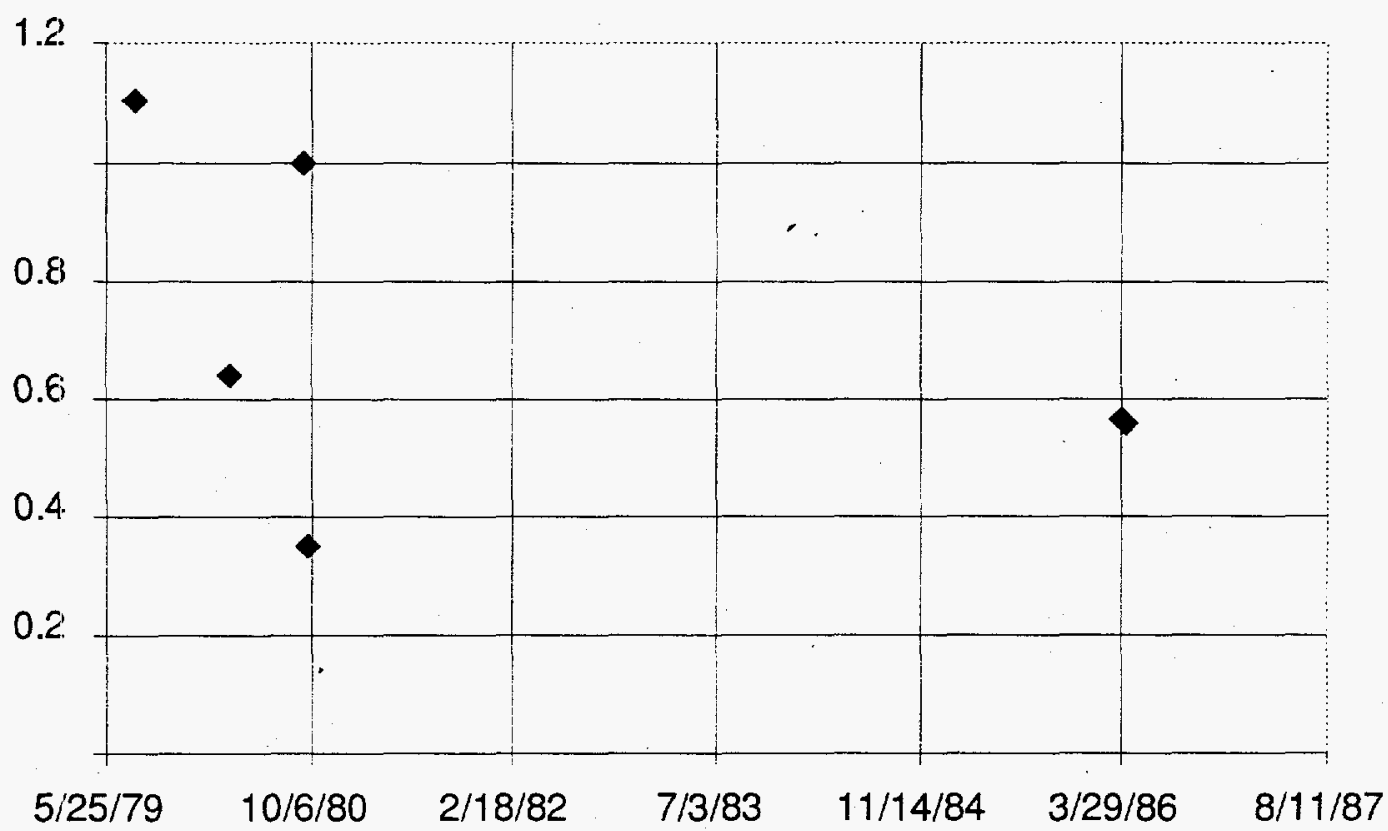

a) \%TOC measurements for SST A-103

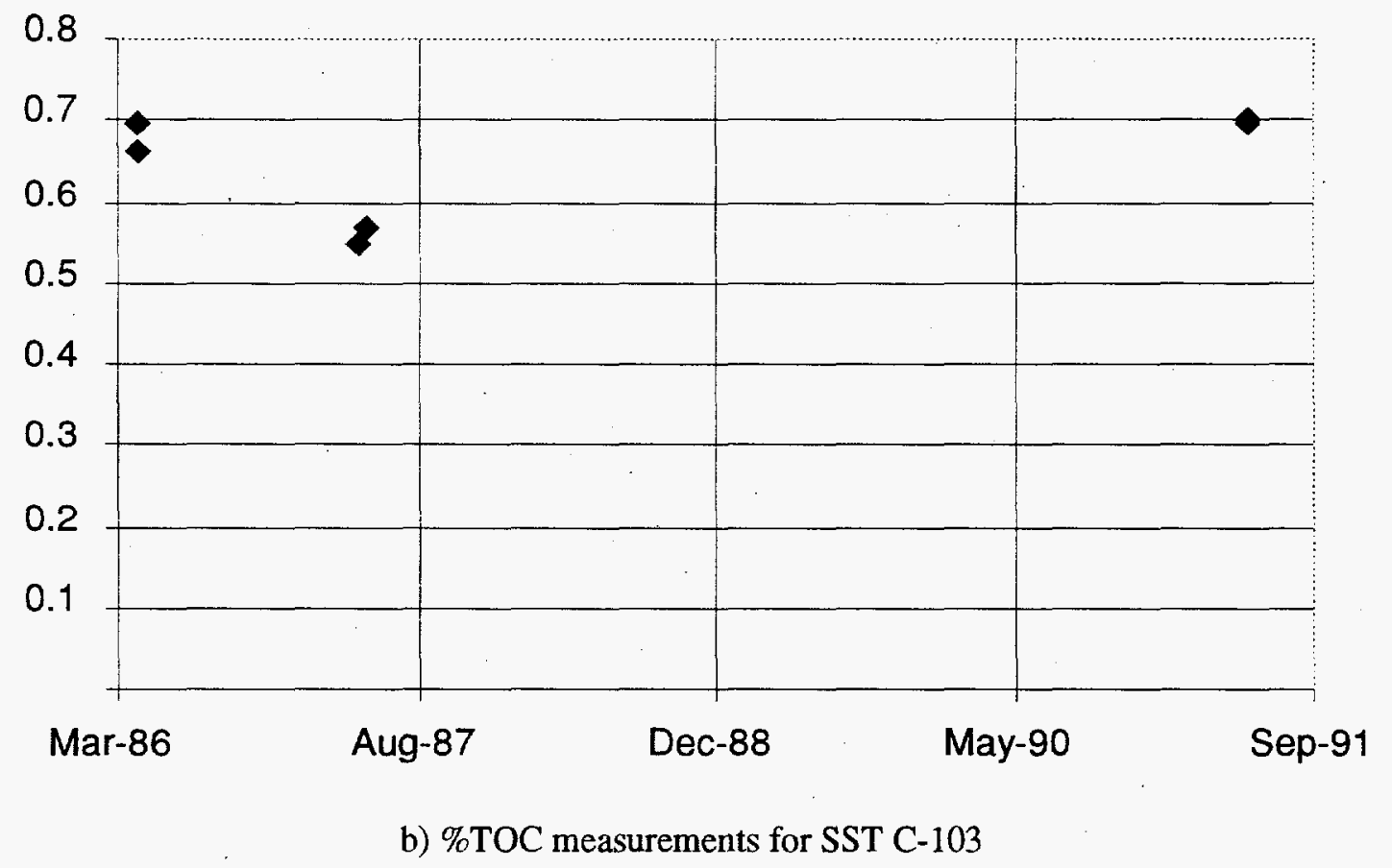

Figure 4.4 TOC Measurements (\%TOC) for Liquid Samples Over Time on Four Selected Single-Shell Tanks 


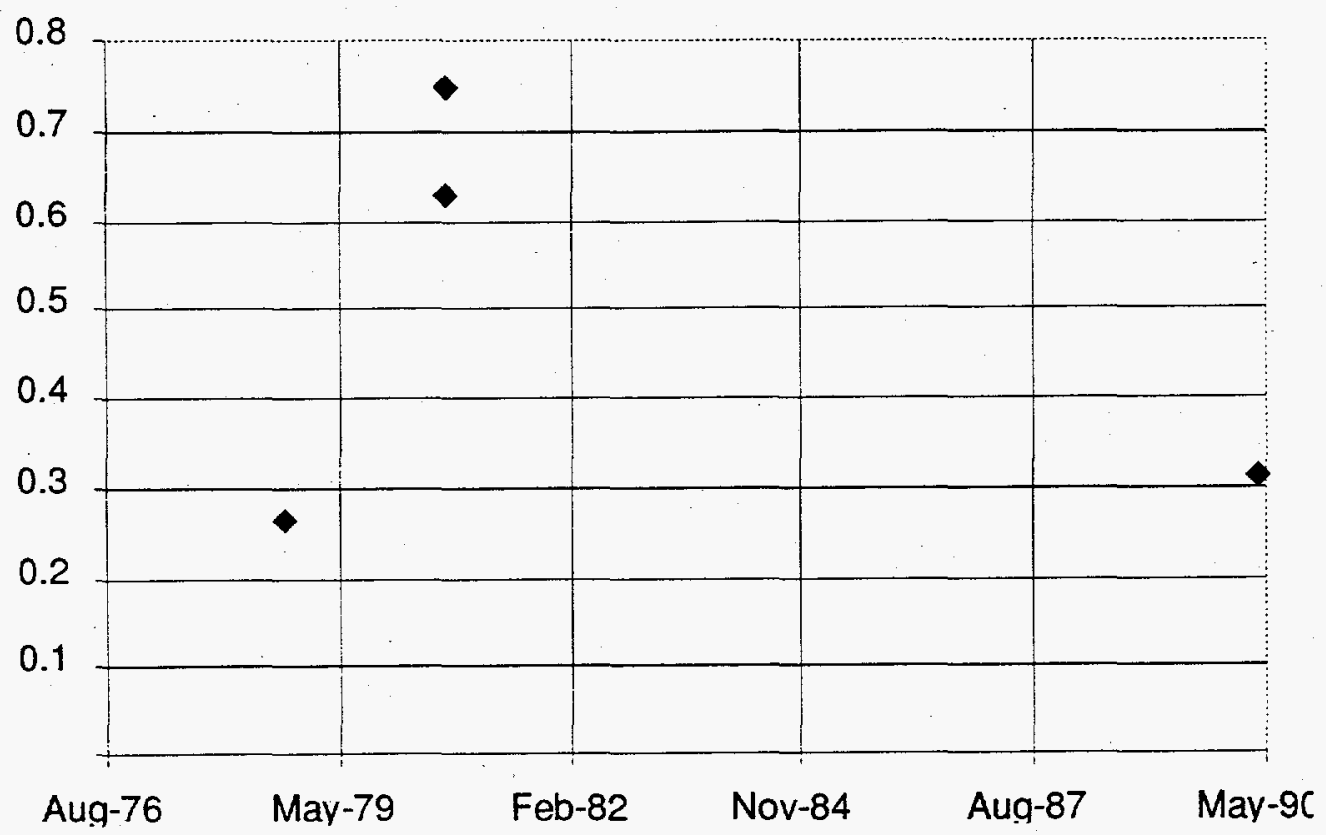

c) \%TOC measurements for SST S-107

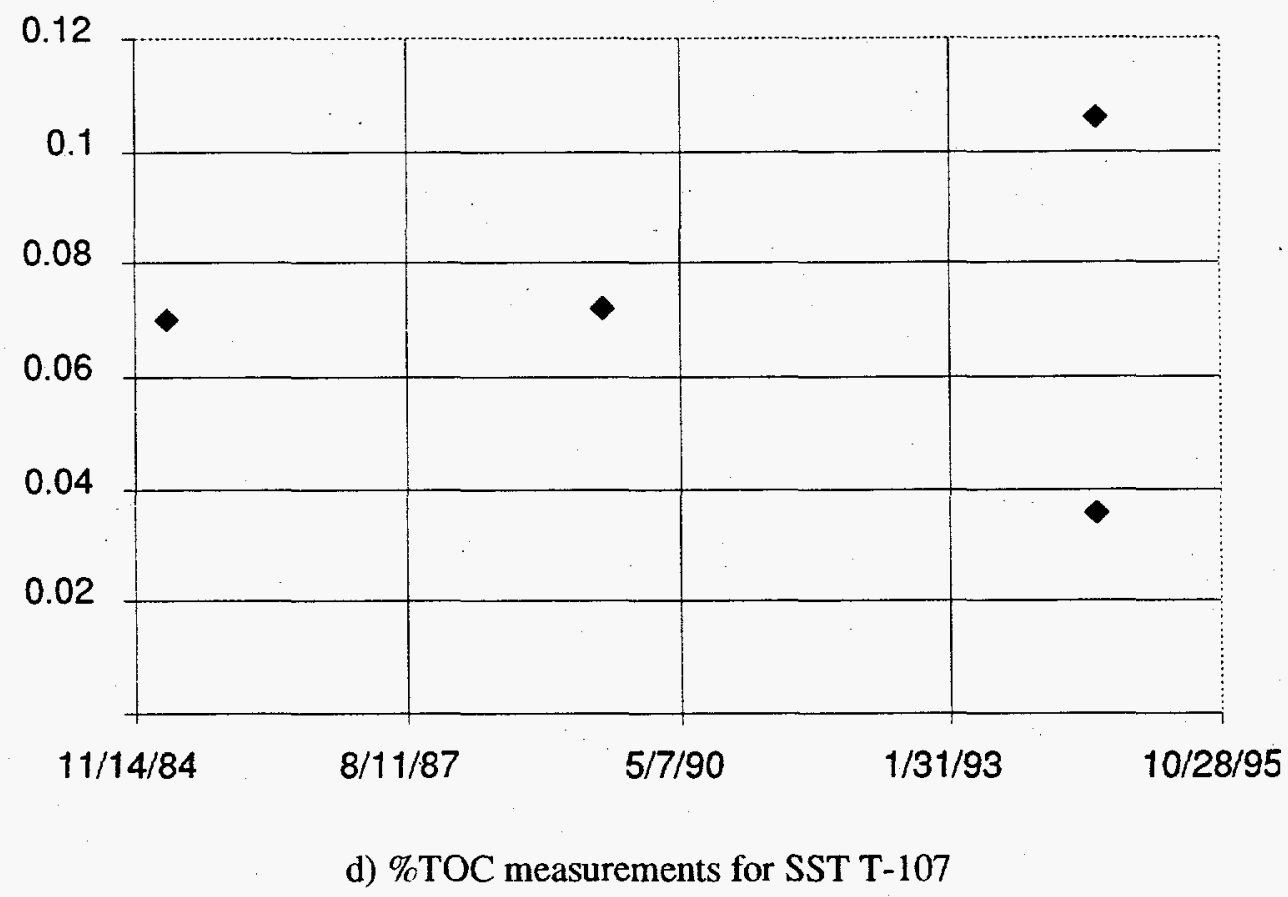

Figure 4.4. (contd) 


\subsection{ANOVA Model Results}

The principal products of the ANOVA model fits described in Section 4.0 produce median and "worst 5\%" TOC and moisture estimates for each tank. Two other important products of the fits are the standard errors of the median and worst $5 \%$ estimates. These standard errors allow the uncertainty associated with each estimate to be evaluated. The median estimates provide a description for the TOC, moisture concentrations in "typical" tank waste, while the "worst 5\%" estimates describe the concentration in the worst 5\%.

\subsection{ANOVA Results for TOC}

Section 3.3.1 provides the ANOVA model description of a TOC measurement. There are three variabilities associated with this model: $\sigma_{\mathrm{G}}^{2}$, between-group variability; $\sigma_{\mathrm{T}}^{2}$, between-tank variability; and, finally, $\sigma_{\mathrm{E}}{ }^{2}$, within-tank variability. This model is fit to each phase separately, so an individual tank may have three sets for TOC and moisture measurements.

Table 5.1 summarizes the results of the TOC model fits. The term $\mu$ describes the median level (\%) of TOC in all SSTs. The median TOC is generally less than $0.5 \%$, with the median sludge level being the least $(0.14 \%)$, and saltcake being the greatest $(0.56 \%)$.

The variance components show that within-tank variability $\sigma_{\mathrm{E}}$ is generally the largest, with a relative standard deviation of about $90 \%$. This means that repeated TOC measurements within a tank would be within $90 \%$ of each other about $68 \%$ of the time. Material displaying variability this high is usually classified as "inhomogeneous." The fact that the within-tank variability is high will mean that the worst $5 \%$ of the waste in the tank will be substantially different from the median waste. In fact, with a within-tank relative standard deviation (RSD), the waste can be expected to have a TOC concentration that is $238 \%$ the median value.

For the two solid phases (sludge and saltcake), the between-group variability $\sigma_{\mathrm{G}}$ is much larger than between-tank variability $\sigma_{T}$, providing further proof that the SORWT grouping is an effective strategy for

Table 5.1. Estimated Terms in TOC Model Fit

\begin{tabular}{||l|c|c|c|c|}
\hline \multicolumn{1}{|c|}{ Phase } & $\begin{array}{c}\text { Median (\% TOC) Wet } \\
\text { Basis, } \mu\end{array}$ & $\begin{array}{c}\text { Variability Between-Group, } \\
\sigma_{G}\end{array}$ & $\begin{array}{c}\text { Variability Between-Tank, } \\
\sigma_{\tau}\end{array}$ & $\begin{array}{c}\text { Variability Within-Tank, } \\
\sigma_{E}\end{array}$ \\
\hline Liquid & $0.27 \%$ & $53 \%$ & $68 \%$ & $83 \%$ \\
\hline Saltcake & $0.56 \%$ & $39 \%$ & $0 \%$ & $112 \%$ \\
\hline Sludge & $0.14 \%$ & $99 \%$ & $58 \%$ & $83 \%$ \\
\hline Average & $0.32 \%$ & $64 \%$ & $42 \%$ & $93 \%$ \\
\hline
\end{tabular}


estimating TOC in unsampled tanks. In fact, the present ANOVA fit on the saltcake data shows that between tank variability is essentially zero. If this is confirmed by further measurements, this would imply that the group TOC estimate would be the most effective method for estimating TOC in all tanks (both sampled and unsampled).

The variabilities presented in Table 5.1 for sludge are graphically illustrated in Figure 5.1. In this figure, the estimated model terms for groups $G_{i}$, tanks $T_{i j}$, and residuals $E_{i j k}$ are plotted so that the reader can judge the variability due to each set of terms. The variabilities $\sigma_{\mathrm{G}}, \sigma_{\mathrm{T}}$, and $\sigma_{\mathrm{E}}$ simply represent the standard deviations of the three populations presented in Figure 5.1.

In Figure 5.2 , the tank median estimates produced by the ANOVA model are visually compared against the actual data. For each tank, the plot presents 1) the median estimate (denoted by "o"), 2) the $95 \%$ confidence bounds on this estimate (identified by square brackets "[ ]"), 3) the log-mean of the data (denoted by "f", and 4) the data values (denoted by "*"). Since the data are log-normally distributed, the points are plotted on a log scale.

As shown, that when more than three samples are taken from a tank, the ANOVA model estimate is essentially equivalent to the log-mean. (For example, compare the two estimates in U110, TY106). On the other hand, when fewer samples have been taken from the tank (for example, U103), then the ANOVA model forms an estimate by taking a weighted average of the group and tank means (on the log scale). Such an estimate is justified because it is more accurate than the simple tank mean; a tank mean computed from one or two measurements contains substantial uncertainty, and in this case, a group mean is a better estimate.

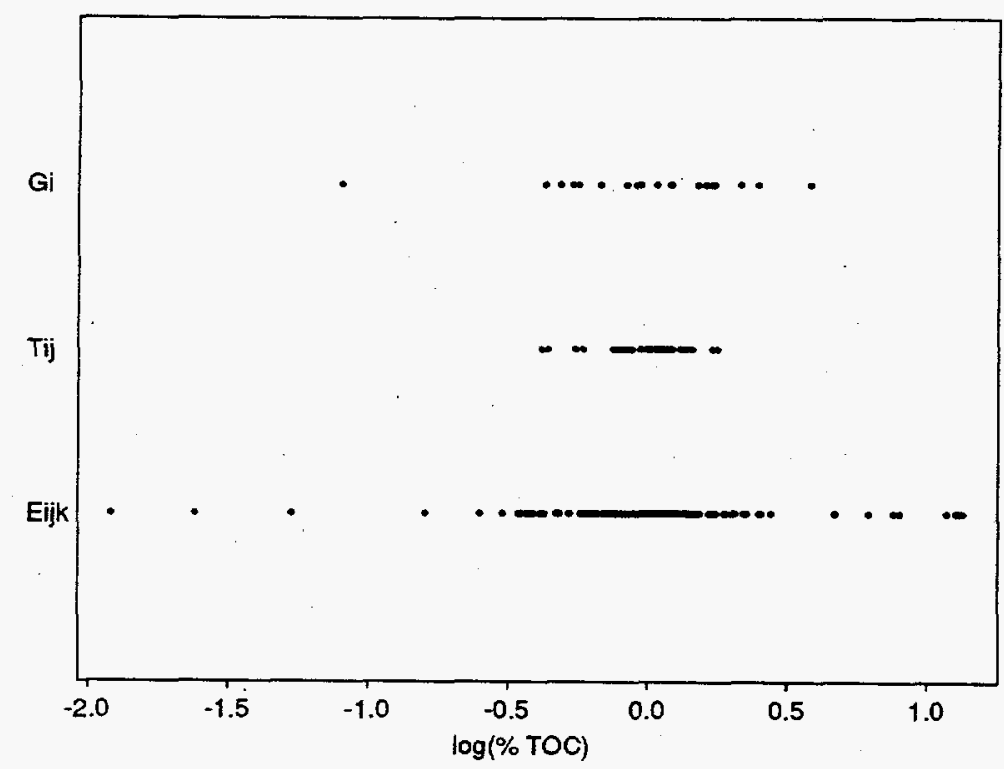

Figure 5.1. Model Terms for Sludge TOC Phase Waste 


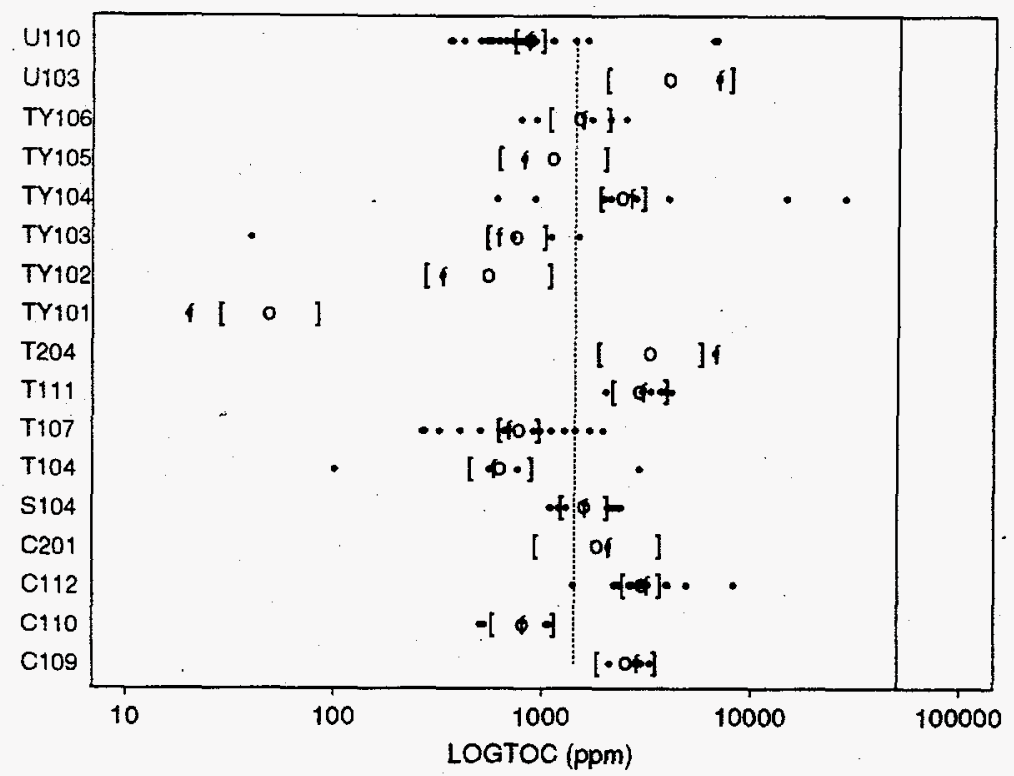

Figure 5.2. Plot of Median Sludge Estimates Versus Data for Selected Tanks

This method of estimation can sometimes produce estimates that are smaller than the simple log-mean estimates. (Estimates are said to be shrunk to the mean.) Nevertheless, if the distributional assumptions regarding the data are correct, that the data are log-normally distributed, this should be a better estimate.

Figure 5.3a, b, and c presents quantile-quantile ("Q-Q") plots of the model terms $G_{i}, T_{i j}$, and $E_{i j k}$ for the liquid phase measurements. Q-Q plots compare the terms against the values that should originate from a normal distribution. If the terms are normally distributed, the points in the Q-Q plot will fall on a straight line. As depicted in the figures, terms generally fall on a straight line, and would consequently be considered normally distributed.

Tables 5.2, through 5.4 contain a summary of the tank wastes estimates for liquids, saltcakes, and sludges, respectively. These tables present the tanks with the highest "worst 5\%" TOC measurements in the three phases. Note there are a few tanks (such as SX106, A106, in Table 5.2, and B202 in Table 5.4) that have very large TOC estimates for the worst $5 \%$ of the waste. These are caused by an unusually high in-tank variability in these tanks. The two tables of most interest are those associated with the saltcake and sludge phases. As can be seen from the table, the worst $5 \%$ of the waste in saltcake is estimated to have just a little over 5\% TOC. In sludge waste, one tank has a 7.6\% TOC (B202), and this is again due to an anomalously high within-tank variability. The worst $5 \%$ of other sludge waste is below $3 \%$ TOC, according to Table 5.4. Appendix J presents the ANOVA TOC results for the 149 SSTs for all three phases. 


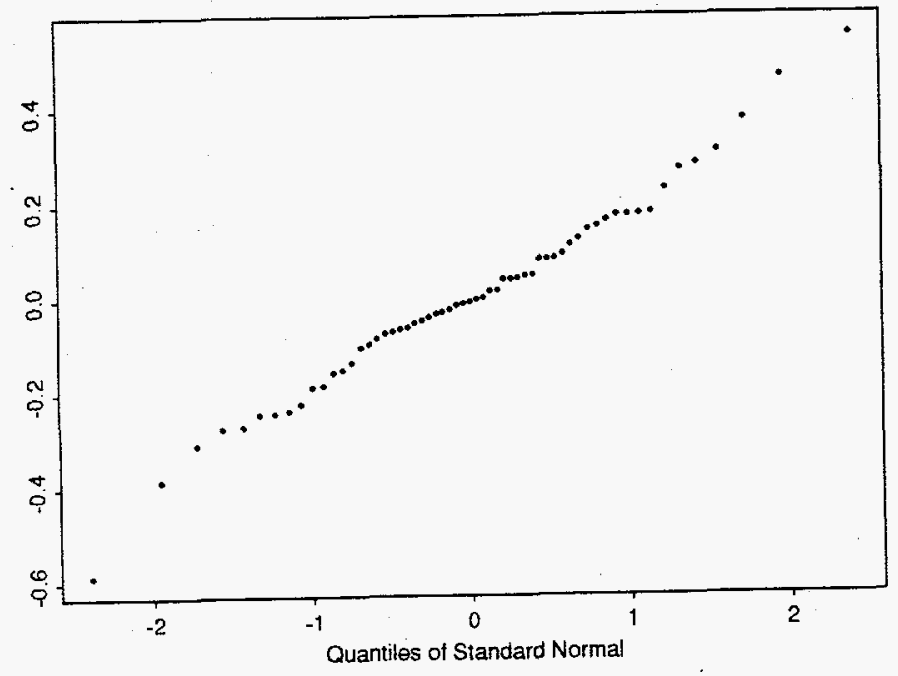

Figure 5.3a. Quantile/Quantile Plots for the Terms; $T$ (tank) Terms from the Liquid ANOVA Fit (A linear relationship in each case indicates a good model fit.)

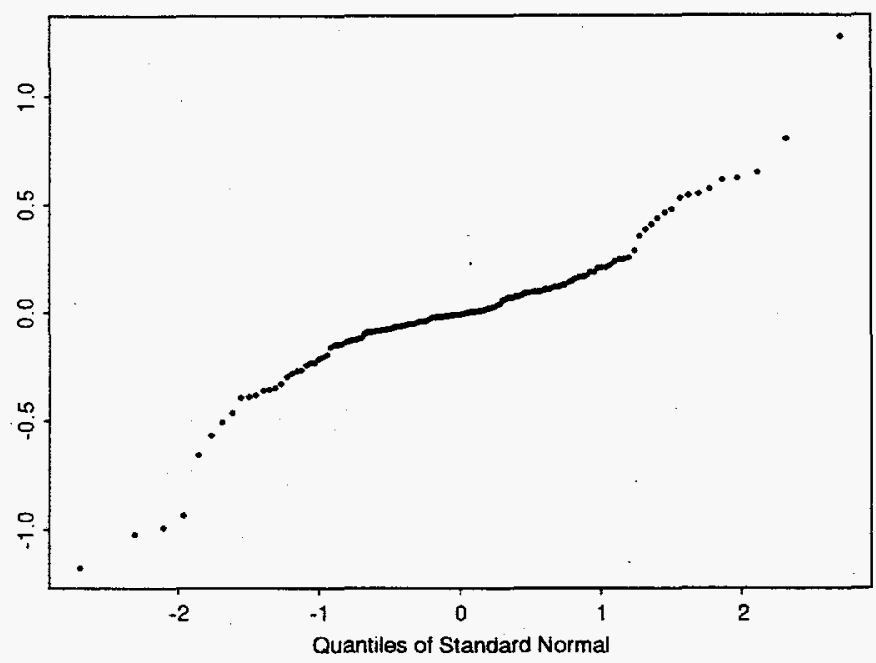

Figure 5.3b. Quantile/Quantile Plots for the Terms; G (SORWT group) Terms from the Liquid ANOVA Fit (A linear relationship in each case indicates a good model fit.) 


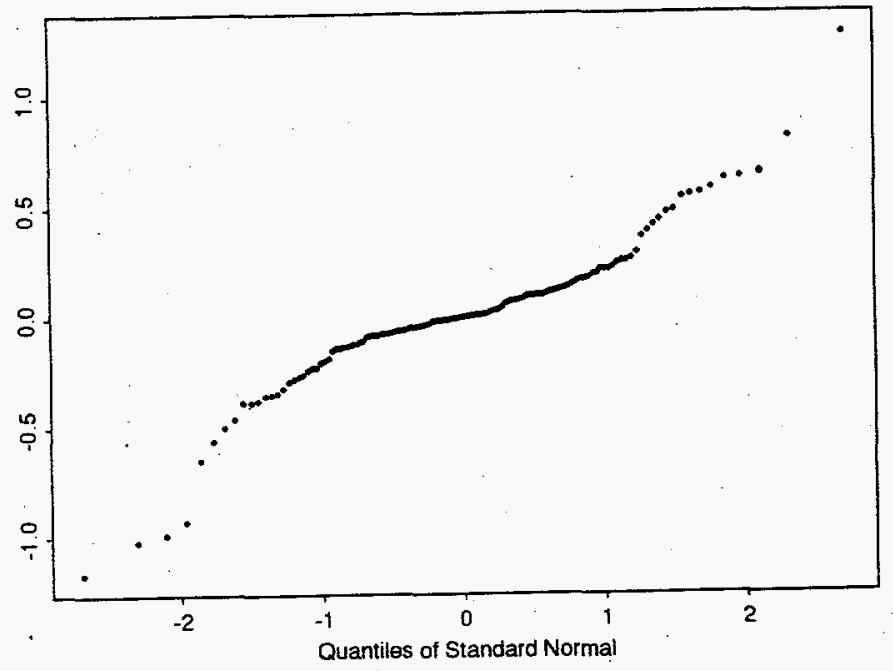

Figure 5.3c. Quantile/Quantile Plots for the Terms; E (residuals) Terms from the Liquid ANOVA Fit (A linear relationship in each case indicates a good model fit.)

Table 5.2. Highest "Worst 5\%" TOC Estimates in the Liquid Phase

\begin{tabular}{||c|c|c|c|c||}
\hline & & \multicolumn{2}{|c|}{ \% TOC (wet basis) } & $\begin{array}{c}\text { \% TOC (wet basis) 95\% } \\
\text { Confidence Bound }\end{array}$ \\
\hline \multicolumn{1}{|c|}{ Tank } & SORWT Group & Median Estimate & Worst 5\% & Worst 5\% \\
\hline SX106 & I & 2.0 & 25 & 25 \\
\hline A106 & XXXA & 0.1 & 25 & 25 \\
\hline U106 & VII & 1.6 & 6.2 & 16.6 \\
\hline AX102 & XXVIII & 1.1 & 4.4 & 8.9 \\
\hline TX118 & XXII & 0.2 & 4.2 & 25 \\
\hline U111 & VII & 1.0 & 4.2 & 11.0 \\
\hline A101 & IX & 0.9 & 3.8 & 5.7 \\
\hline S102 & I & 0.9 & 3.5 & 7.7 \\
\hline AX103 & XXVII & 0.8 & 3.3 & 6.2 \\
\hline AX101 & IX & 0.8 & 3.0 & 5.4 \\
\hline
\end{tabular}


Table 5.3. Highest "Worst 5\%" TOC Estimates in the Saltcake Phase

\begin{tabular}{|c|c|c|c|c|}
\hline \multirow[b]{2}{*}{ Tank } & \multirow[b]{2}{*}{ SORWT Group } & \multicolumn{2}{|c|}{$\%$ TOC (wet basis) } & \multirow{2}{*}{$\begin{array}{c}\% \text { TOC (wet basis) } 95 \% \\
\text { Confidence Bound } \\
\text { Worst } 5 \%\end{array}$} \\
\hline & & Median Estimate & Worst $5 \%$ & \\
\hline U105 & $X$ & 0.7 & 5.2 & 17.9 \\
\hline U107 & $\mathrm{X}$ & 0.7 & 5.2 & 17.9 \\
\hline U108 & $X$ & 0.7 & 5.2 & 17.9 \\
\hline U109 & $X$ & 0.7 & 5.2 & 17.9 \\
\hline BY 101 & III & 0.7 & 5.1 & 16.4 \\
\hline BY 103 & III & 0.7 & 5.1 & 16.4. \\
\hline BY104 & III & 0.7 & 5.1 & 16.4 \\
\hline BY 105 & III & 0.7 & 5.1 & 16.4 \\
\hline BY106 & III & 0.7 & 5.1 & 16.4 \\
\hline BY107 & III & 0.7 & 5.1 & 16.4 \\
\hline BY 108 & III & 0.7 & 5.1 & 16.4 \\
\hline BY 110 & III & 0.7 & 5.1 & 16.4 \\
\hline BY111 & III & 0.7 & 5.1 & 16.4 \\
\hline BY112 & III & 0.7 & 5.1 & 16.4 \\
\hline TX115 & VII & 0.6 & 5.0 & 16.6 \\
\hline $\mathrm{U} 102$ & VII & 0.6 & 5.0 & 16.6 \\
\hline U103 & VII & 0.6 & 5.0 & 16.6 \\
\hline U106 & V̇II & 0.6 & 5.0 & 16.6 \\
\hline $\mathrm{U} 111$ & VII & 0.6 & 5.0 & 16.6 \\
\hline TX108 & XXII & 0.6 & 4.7 & 16.1 \\
\hline
\end{tabular}


Table 5.4. Highest "Worst 5\%" TOC Estimates in the Sludge Phase

\begin{tabular}{||c|c|c|c|c||}
\hline & & \multicolumn{2}{|c|}{ \% TOC (wet basis) } & $\begin{array}{c}\text { \% TOC (wet basis) 95\% } \\
\text { Confidence Bound }\end{array}$ \\
\hline Tank & SORWT Group & Median Estimate & Worst 5\% & Worst 5\% \\
\hline B202 & V & 0.2 & 7.6 & 25 \\
\hline A103 & IX & 0.7 & 2.6 & 5.7 \\
\hline A102 & IX & 0.6 & 2.5 & 5.5 \\
\hline A101 & IX & 0.6 & 2.4 & 6.1 \\
\hline AX101 & IX & 0.5 & 2.1 & 7.3 \\
\hline A106 & XXXA & 0.5 & 1.9 & 4.6 \\
\hline BX112 & XII & 0.4 & 1.6 & 3.3 \\
\hline U103 & VII & 0.4 & 1.6 & 4.9 \\
\hline T204 & V & 0.3 & 1.3 & 3.2 \\
\hline B107 & XII & 0.3 & 1.2 & 4.9 \\
\hline
\end{tabular}

\subsection{ANOVA Results for Moisture in Sludge and Liquid}

A moisture measurement in the sludge and liquid phases is assumed to obey the following ANOVA model:

$$
M_{i j k}=\mu+G_{i}+T_{i j}+E_{i j k}
$$

where i represents a SORWT group, ij a tank, and ijk a measurement taken from tank ij. This ANOVA model is exactly the same as the TOC model, except the data are not in the logarthmic form. There are three variabilities associated with this model: $\sigma_{\mathrm{G}}, \sigma_{\mathrm{T}}$, and $\sigma_{\mathrm{E}} \sigma_{\mathrm{G}}$, between-group variability; $\sigma_{\mathrm{T}}$, betweentank variability; and $\sigma_{E}$, within-tank variability. This model is fit to each phase separately.

Table 5.5 presents the a summary of the variables present in the moisture measurements. The liquids are, on average, $65 \%$ water, and sludges are $45 \%$ water. It is interesting that liquid waste displays an in-tank variability of $15 \%$. This is not representative of a well-mixed liquid.

Moisture in sludge displays a large within-tank variability (28\%), a strong SORWT group effect and no between-tank variability. The SORWT grouping seems to be effective in predicting the moisture in sludges. 
Table 5.5. Estimated Terms for Moisture Model Fit of the Sludge and Liquid Phases

\begin{tabular}{||l|c|c|c|c||}
\hline & \multicolumn{4}{|c||}{ Model Terms } \\
\hline Phase & $\boldsymbol{\mu}$ & $\sigma_{\mathrm{G}}$ & $\sigma_{\Upsilon}$ & $\sigma_{\mathrm{E}}$ \\
\hline Liquid & $65 \%$ & $12 \%$ & $15 \%$ & $14 \%$ \\
\hline Sludge & $45 \%$ & $24 \%$ & $0 \%$ & $28 \%$ \\
\hline Average & $55 \%$ & $18 \%$ & $8 \%$ & $21 \%$ \\
\hline
\end{tabular}

\subsection{ANOVA Results for Moisture in Saltcake}

The moisture measurements for saltcake were treated differently than the sludge and liquid phases. The following ANOVA model was employed:

$$
\log \left(M_{i j k}\right)=\mu+V_{i}+P_{j}+R_{k}+T_{i j k}+E_{i j k}
$$

where the tank groups are defined by indices $i, j$, and $k$. The index $i$ identifies whether or not the tank is actively ventilated, $j$ whether or not the tank has been jet-pumped, and $k$ whether or not the tank contains REDOX waste. This more complicated model was adopted for three reasons:

1. An evaluation of ANOVA residuals indicated that a logarthmic distribution is appropriate.

2. Tank ventilation and jet-pumping tank waste were shown to have an important effect on moisture.

3. There were too many SORWT groups to use with the saltcake moisture data (only 20 measurements), so the SORWT model was reduced to just two groups, REDOX and non-REDOX waste.

Table 5.6 provides the estimated terms for the saltcake moisture fit. This table shows that the typical moisture content in saltcake is about $14 \%$. The grouping variables (ventilation, pumping, and waste type) are significant, accounting for about $28 \%$ of the variability in the data. Within-tank variability is about the same as that reported for liquid, but lower than the variability reported for sludge.

From Table 5.6 the effect of pumping a tank or putting it on active ventilation can be calculated. Suppose, for example, that the moisture content of a saltcake tank waste is $25 \%$ and it is jet-pumped. Its moisture content after jet-pumping would be estimated as:

$$
\text { Moisture After Pumping }=\frac{63}{160} * 25 \%=9.8 \%
$$


Table 5.6. Estimated Terms for Moisture Model Fit of the Saltcake Phase

\begin{tabular}{|l|c|}
\hline \multicolumn{1}{|c|}{ Term } & Moisture \\
\hline Mean & $14 \%$ \\
\hline R=REDOX & $71 \%$ \\
\hline R=Non-REDOX & $141 \%$ \\
\hline$P=$ Pumped & $63 \%$ \\
\hline P=Not Pumped & $160 \%$ \\
\hline V=Active & $76 \%$ \\
\hline V=Not Active & $132 \%$ \\
\hline$\sigma_{\mp}$ Between-Tank Variability & $22 \%$ \\
\hline$\sigma_{\mathrm{E}}$ Within-Tank Variability & $17 \%$ \\
\hline
\end{tabular}

Similarly, if the tank waste condition was changed from passive to active ventilation, its moisture content upon active ventilation would be estimated as:

$$
\text { Moisture of Waste in Active Ventilated Tank }=\frac{76}{132} * 25 \%=14 \%
$$

Appendix $L$ presents the moisture grouping for each saltcake waste. Appendix $G$ presents the estimates of moisture for all SSTs.

\subsection{Exceedance Probabilities for the Worst 5\% of the Waste}

The TOC and moisture estimates discussed in the last section can be plotted on the safety diagram presented in Figure 5.4 to determine whether or not an individual tank is safe. This would be a reasonable procedure if the uncertainty in the estimates is small. However, as can be seen from the results presented in the last two sections, it is not; any evaluations should attempt to understand and account for these uncertainties.

One common methodology for presenting these uncertainties is through the use of "confidence bounds." All TOC and moisture estimate tables presented in Appendix I also include their $95 \%$ confidence bounds. These $95 \%$ bounds can be plotted on the safety diagram to allow the reader to gauge the uncertainty in the estimates.

Figures 5.5 through 5.7 simultaneously illustrate the three most important TOC and moisture estimates from this study. Each set of connected lines in this plot represents a tank. The open point on the line represents the median TOC and moisture estimate, while the solid point represents our estimate for 


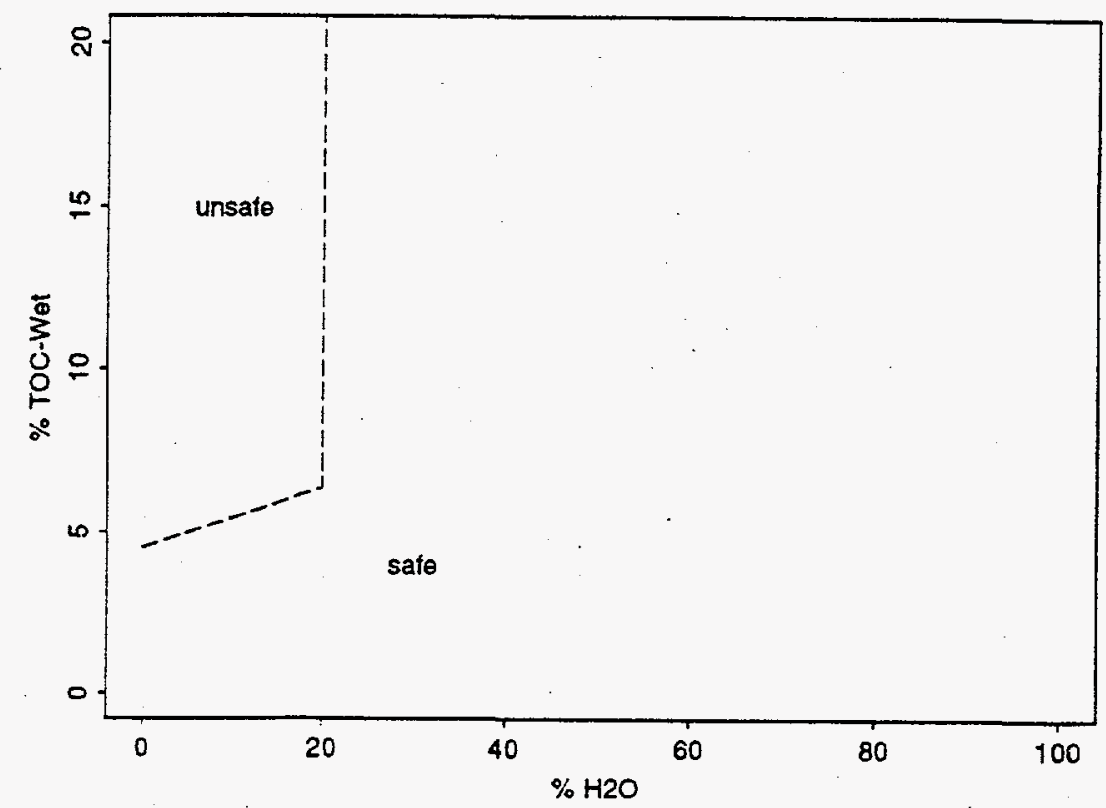

Figure 5.4. Preliminary Organics Tank Safety Criteria Identified by the TOC Moisture Concentrations

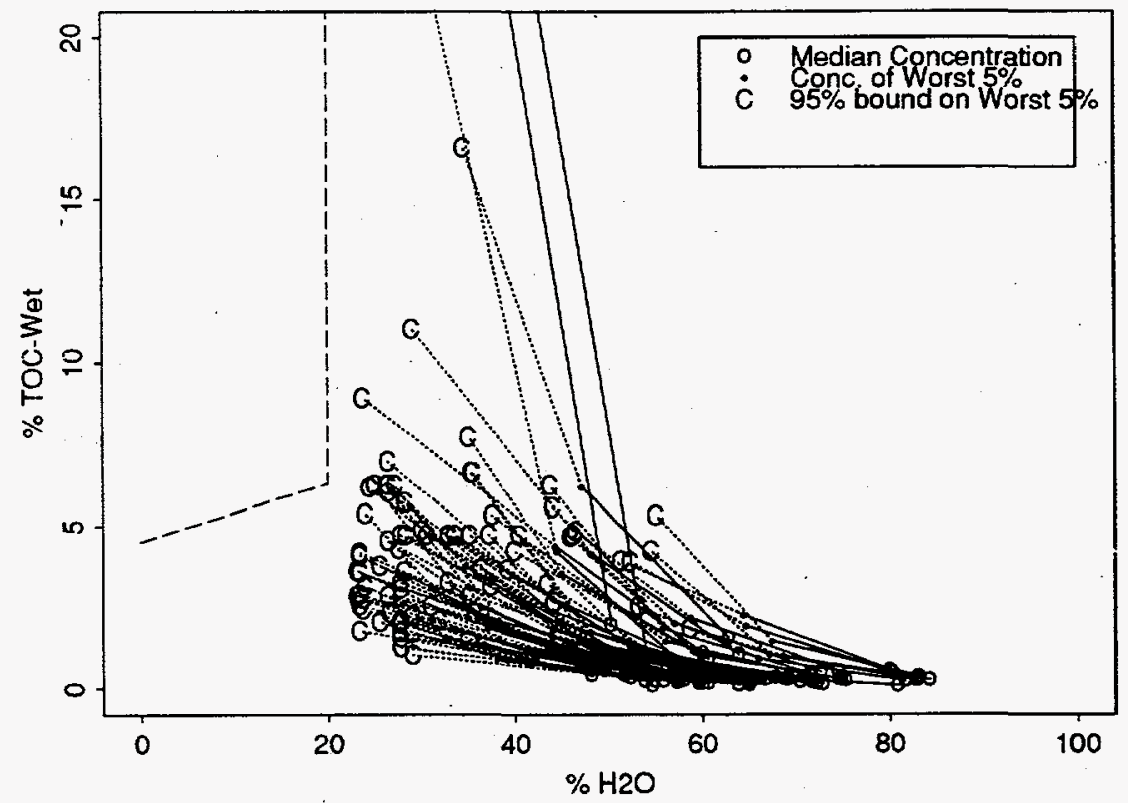

Figure 5.5. ANOVA Estimates for the Median, Worst 5\% of the Waste, and 95\% Confidence Bound on the "Worst 5\%" of the Liquid Phase Tank Wastes (Note: the dotted line indicates the safety criteria.) 


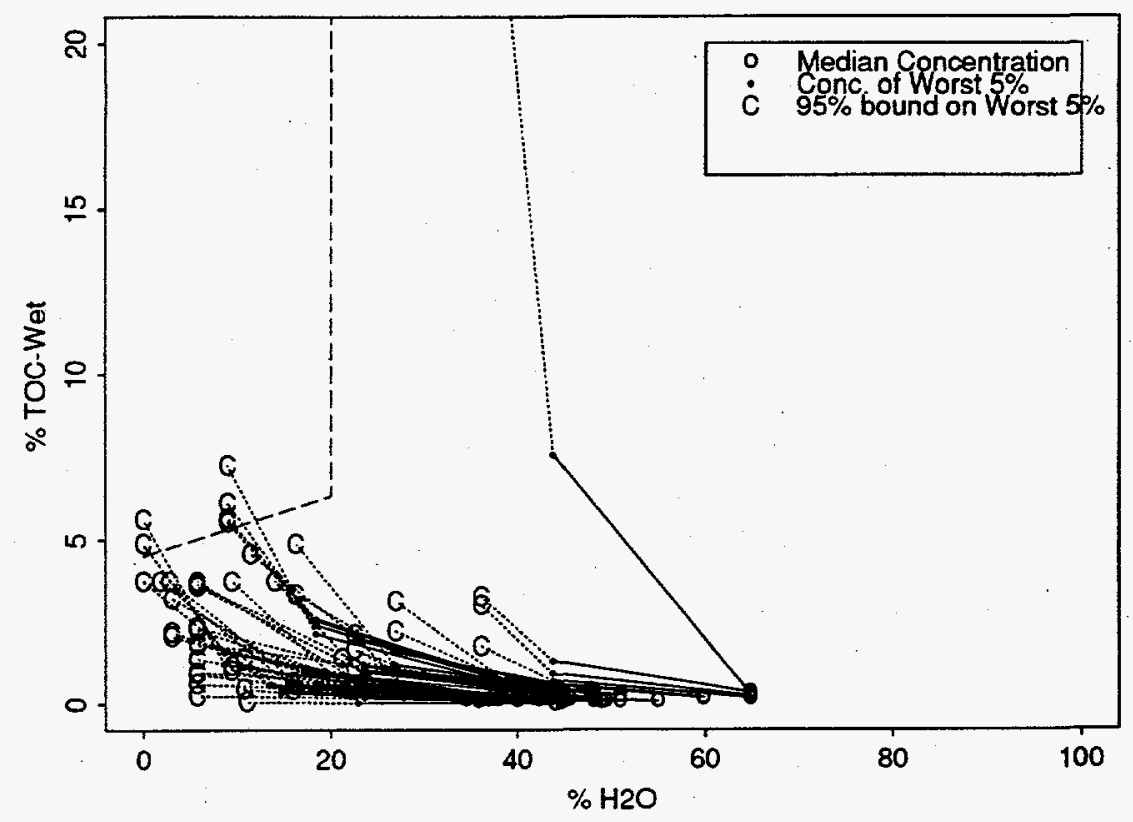

Figure 5.6. ANOVA Estimates for the Median, Worst 5\% of the Waste, and $95 \%$ Confidence Bound on the "Worst 5\%" of the Sludge Phase Tank Wastes (Note: the dotted line indicates the safety criteria.)

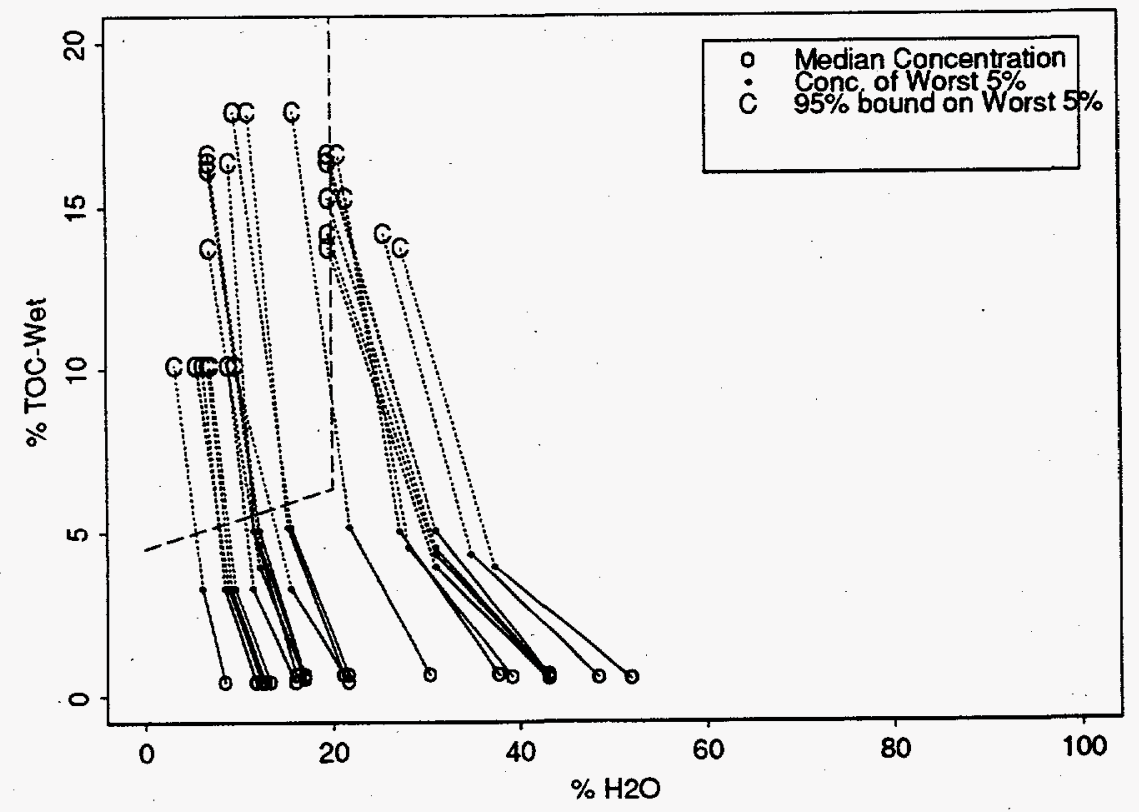

Figure 5.7. ANOVA Estimates for the Median, Worst $5 \%$ of the Waste, and 95\% Confidence Bound on the "Worst 5\%" of the Saltcake Phase Tank Wastes (Note: the dotted line indicates the safety criteria.) 
the worst $5 \%$. Finally, the point identified with a " $\mathrm{C}$ " represents the $95 \%$ confidence bound on the worst $5 \%$. Thus the distance between the open and closed dot represents the consequences of going from a tank median to worst $5 \%$ measurement (and also describes within tank variability), while the distance between the " $\mathrm{C}$ " and closed dot represents uncertainty in the worst $5 \%$ estimate.

Figures 5.5 through 5.7 give perhaps the most concise summary of the state of the waste. As seen in the safety diagram, there are no problems with the liquid phase in any of the tanks; even the $95 \%$ bounds on the worst $5 \%$ do not cross into the unsafe region. For the sludge phase, no worst $5 \%$ values are in the unsafe region, but five $95 \%$ bounds are. Finally, a substantial proportion of the saltcake $95 \%$ bounds are in the unsafe region, indicating that it would be valuable to take more measurements in saltcake tanks. However, even in saltcake, none of the worst $5 \%$ estimates are actually in the unsafe region.

Another alternative for evaluating the uncertainty in the TOC and moisture estimates is to utilize an "exceedance probability." This probability is defined to be the probability that the actual tank TOC and moisture value is in the unsafe region, given the available information (i.e., the current TOC and moisture estimate and its associated uncertainty). The exceedance probability is very similar to a confidence bound, except that it attempts to account for the shape of the safety region more appropriately.

The exceedance probability provides the best estimate that an individual tank is actually of concern from an organic safety perspective. When exceedance probability is near 0 (i.e., less than $2 \%$ ), an individual tank waste should be classified as safe. Alternatively, when the exceedance probability is large (say, above 50\%), then the tank should be considered from a safety perspective, and it probably is wise to characterize the tank further and consider mitigation measures. The current study indicates there are no tank wastes with exceedance probabilities greater than approximately $35 \%$.

When the exceedance probability is neither high nor low (i.e., between $50 \%$ and $2 \%$ ), then additional measurements may be advantageous. In this case, more measurements will reduce the estimate's uncertainty and drive the exceedance probability to either 1 or 0 . All 65 saltcake wastes and 22 of the sludge wastes fall into this category.

Tables 5.7 through 5.8 present the exceedance probabilities for the three waste phases. The tables list two sets of exceedance probabilities, one for the median (TOC and moisture) and the other for the "worst $5 \%$ " of the waste. The important exceedance probability is that associated with the "worst 5\%"; the exceedance probability associated with the median value is given only for the sake of comparison. The tanks listed in the tables are ordered by the exceedance probability on the "worst $5 \%$ " of the waste, so the tables present the tanks that are most likely to be of concern from a safety perspective.

Table 5.7 demonstrates that the exceedance probability in the liquid phase is very low; Tank AX102, the worst tank, only has a $1 \%$ exceedance probability, so no liquid in any of the tanks would be considered unsafe.

For many saltcake tanks, the exceedance probability is quite substantial (Table 5.8). The saltcake tank wastes have an exceedance probability that ranges up to $36 \%$. Saltcake tank wastes are good 
Table 5.7. Tanks with the Highest Exceedance Probability for the "Worst 5\%" of Liquid Phase Waste

\begin{tabular}{|c|c|c|c|c|c|c|c|}
\hline \multirow[b]{2}{*}{ Tank } & \multirow[b]{2}{*}{$\begin{array}{c}\text { SORWT } \\
\text { Group }\end{array}$} & \multicolumn{2}{|c|}{ Median } & \multirow[b]{2}{*}{$\begin{array}{c}\text { Exceed. } \\
\text { Prob. }\end{array}$} & \multicolumn{2}{|c|}{ Worst $5 \%$} & \multirow[b]{2}{*}{$\begin{array}{c}\text { Exceed } \\
\text { Prob. }\end{array}$} \\
\hline & & $\% \mathrm{TOC}^{(\mathrm{a})}$ & $\% \mathrm{H}_{2} \mathrm{O}$ & & $\% \mathrm{TOC}^{(\mathrm{a})}$ & $\% \mathrm{H}_{2} \mathrm{O}$ & \\
\hline $\mathrm{AX} 102$ & XXVIII & 1.10 & 59.99 & 0.00 & 4.39 & 44.31 & 1.05 \\
\hline TX118 & $\mathrm{XXII}$ & 0.15 & 60.13 & 0.01 & 4.22 & 44.45 & 1.01 \\
\hline SX106 & I & 1.97 & 50.25 & 0.00 & 20.00 & 34.57 & 0.57 \\
\hline U111 & VII & 1.04 & 63.88 & 0.00 & 4.15 & 48.20 & 0.29 \\
\hline S110 & I & 0.69 & 59.72 & 0.00 & 2.77 & 44.03 & 0.18 \\
\hline $\mathrm{AX} 103$ & XXVIII & 0.82 & 53.12 & 0.00 & 3.27 & 37.44 & 0.17 \\
\hline TX105 & I & 0.60 & 59.72 & 0.00 & 2.39 & 44.03 & 0.12 \\
\hline S103 & I & 0.46 & 59.72 & 0.00 & 1.85 & 44.03 & 0.11 \\
\hline S108 & I & 0.46 & 59.72 & 0.00 & 1.85 & 44.03 & 0.11 \\
\hline S109 & I & 0.46 & 59.72 & 0.00 & 1.85 & 44.03 & 0.11 \\
\hline
\end{tabular}

candidates for further sampling. Table 5.9 lists 22 sludge tanks with an exceedance probability that is greater than $2 \%$. The highest exceedance probability for sludges is $10 \%$ on U102, indicating that a few extra measurements in sludge might be beneficial.

Since four SORWT groups contain all but one of the tanks with high exceedance probabilities, just four or five extra measurements might be sufficient to reduce all sludge tank exceedance probabilities to below $2 \%$.

\subsection{Mass Balance Comparison}

The TOC estimates predicted for each of the SSTs according to the weighted average and ANOVA models can be compared to estimated quantities of total inventories of organics added to the tank farm. The tank estimates in this report do not include the inventory of organics in double-shell tanks, so the comparison may be incomplete. However, a mass balance comparison is useful for providing an estimate for validation.

Several of Hanford's process plants have used organic chemicals. PUREX Plant, B-Plant, Z-Plant, U-Plant and C-Plant all involved the use of organic chemicals that may have discharged to the tank farms 
Table 5.8. Tanks with the Highest Exceedance Probability for the "Worst 5\%" of Saltcake Phase Waste

\begin{tabular}{|c|c|c|c|c|c|c|c|}
\hline \multirow[b]{2}{*}{ Tank } & \multirow{2}{*}{$\begin{array}{c}\text { SORWT } \\
\text { Group }\end{array}$} & \multicolumn{2}{|c|}{ Median } & \multirow{2}{*}{$\begin{array}{c}\text { Exceed. } \\
\text { Prob. }\end{array}$} & \multicolumn{2}{|c|}{ Worst $5 \%$} & \multirow{2}{*}{$\begin{array}{c}\text { Exceed. } \\
\text { Prob. }\end{array}$} \\
\hline & & $\% \mathrm{TOC}^{(\mathrm{a})}$ & $\% \mathrm{H}_{2} \mathrm{O}$ & & $\% \mathrm{TOC}^{(\mathrm{a})}$ & $\% \mathrm{H}_{2} \mathrm{O}$ & \\
\hline BY104 & III & 0.65 & 1.21 & 0 & 5.07 & 1.06 & 36.52 \\
\hline TX115 & VII & 0.65 & 1.23 & 0 & 5.05 & 1.09 & 33.16 \\
\hline BY101 & III & 0.65 & 1.23 & 0 & 5.07 & 1.09 & 33.14 \\
\hline BY107 & III & 0.65 & 1.23 & 0 & 5.07 & 1.09 & 33.14 \\
\hline BY108 & III & 0.65 & 1.23 & 0 & 5.07 & 1.09 & 33.14 \\
\hline BY110 & III & 0.65 & 1.23 & 0 & 5.07 & 1.09 & 33.14 \\
\hline BY111 & III & 0.65 & 1.23 & 0 & 5.07 & 1.09 & 33.14 \\
\hline BY112 & III & 0.65 & 1.23 & 0 & 5.07 & 1.09 & 33.14 \\
\hline TX108 & XXII & 0.60 & 1.23 & 0 & 4.65 & 1.09 & 30.10 \\
\hline TX118 & XXII & 0.60 & 1.23 & 0 & 4.65 & 1.09 & 30.10 \\
\hline S105 & I & 0.42 & 0.93 & 0 & 3.30 & 0.79 & 28.10 \\
\hline TX102 & I & 0.42 & 0.93 & 0 & 3.30 & 0.79 & 28.10 \\
\hline TX105 & I & 0.42 & 0.93 & 0 & 3.30 & 0.79 & 28.10 \\
\hline TX106 & I & 0.42 & 0.93 & 0 & 3.30 & 0.79 & 28.10 \\
\hline $\mathrm{U} 105$ & $\mathrm{X}$ & 0.66 & 1.32 & 0 & 5.17 & 1.18 & 27.78 \\
\hline U107 & $\mathrm{X}$ & 0.66 & 1.33 & 0 & 5.17 & 1.19 & 25.26 \\
\hline U108 & $\mathrm{X}$ & 0.66 & 1.33 & 0 & 5.17 & 1.19 & 25.26 \\
\hline TX109 & II & 0.51 & 1.23 & 0 & 3.96 & 1.09 & 23.51 \\
\hline TX110 & II & 0.51 & 1.23 & 0 & 3.96 & 1.09 & 23.51 \\
\hline $\mathrm{TX} 111$ & II & 0.51 & 1.23 & 0 & 3.96 & 1.09 & 23.51 \\
\hline TX112 & II & 0.51 & 1.23 & 0 & 3.96 & 1.09 & 23.51 \\
\hline
\end{tabular}


Table 5.9. Tanks with the Highest Exceedance Probability for the "Worst 5\%" of Sludge Phase Waste

\begin{tabular}{|c|c|c|c|c|c|c|c|}
\hline \multirow[b]{2}{*}{ Tank } & \multirow[b]{2}{*}{$\begin{array}{c}\text { SORWT } \\
\text { Group }\end{array}$} & \multicolumn{2}{|c|}{ Median } & \multirow[b]{2}{*}{$\begin{array}{c}\text { Exceed. } \\
\text { Prob. }\end{array}$} & \multicolumn{2}{|c|}{ Worst $5 \%$} & \multirow[b]{2}{*}{$\begin{array}{c}\text { Exceed. } \\
\text { Prob. }\end{array}$} \\
\hline & & $\% \mathrm{TOC}^{(\mathrm{a})}$ & $\% \mathrm{H}_{2} \mathrm{O}$ & & $\% \mathrm{TOC}^{(\mathrm{a})}$ & $\% \mathrm{H}_{2} \mathrm{O}$ & \\
\hline U102 & VII & 0.31 & 29.78 & 0.02 & 1.21 & 8.67 & 10.21 \\
\hline U106 & VII & 0.31 & 29.78 & 0.02 & 1.21 & 8.67 & 10.21 \\
\hline U111 & VII & 0.31 & 29.78 & 0.02 & 1.21 & 8.67 & 10.21 \\
\hline U103 & VII & 0.40 & 29.78 & 0.00 & 1.58 & 8.67 & 9.56 \\
\hline AX101 & IX & 0.54 & 39.52 & 0.00 & 2.14 & 18.41 & 8.63 \\
\hline A101 & IX & 0.61 & 39.52 & 0.00 & 2.39 & 18.41 & 7.07 \\
\hline A 103 & IX & 0.65 & 39.52 & 0.00 & 2.58 & 18.41 & 6.28 \\
\hline A 102 & IX & 0.64 & 39.52 & 0.00 & 2.52 & 18.41 & 5.83 \\
\hline B101 & XVIII & 0.14 & 34.51 & 0.00 & 0.56 & 13.40 & 3.35 \\
\hline B102 & XVIII & 0.14 & 34.51 & 0.00 & 0.56 & 13.40 & 3.35 \\
\hline B103 & XVIII & 0.14 & 34.51 & 0.00 & 0.56 & 13.40 & 3.35 \\
\hline U204 & XXXL & 0.14 & 36.96 & 0.00 & 0.56 & 15.85 & 2.74 \\
\hline BY 101 & III & 0.14 & 37.92 & 0.00 & 0.56 & 16.81 & 2.50 \\
\hline BY102 & III & 0.14 & 37.91 & 0.00 & 0.56 & 16.81 & 2.50 \\
\hline BY103 & III & 0.14 & 37.91 & 0.00 & 0.56 & 16.81 & 2.50 \\
\hline U204 & III & 0.14 & 37.91 & 0.00 & 0.56 & 16.81 & 2.50 \\
\hline BY101 & III & 0.14 & 37.91 & 0.00 & 0.56 & 16.81 & 2.50 \\
\hline BY 103 & III & 0.14 & 37.91 & 0.00 & 0.56 & 16.81 & 2.50 \\
\hline BY 104 & III & 0.14 & 37.91 & 0.00 & 0.56 & 16.81 & 2.50 \\
\hline BY 105 & III & 0.14 & 37.91 & 0.00 & 0.56 & 16.81 & 2.50 \\
\hline BY106 & III & 0.14 & 37.91 & 0.00 & 0.56 & 16.81 & 2.50 \\
\hline BY107 & III & 0.14 & 37.91 & 0.00 & 0.56 & 16.81 & 2.50 \\
\hline BY108 & III & 0.14 & 37.91 & 0.00 & 0.56 & 16.81 & 2.50 \\
\hline BY110 & III & 0.14 & 37.91 & 0.00 & 0.56 & 16.81 & 2.50 \\
\hline BY111 & III & 0.14 & 37.91 & 0.00 & 0.56 & 16.81 & 2.50 \\
\hline BY112 & III & 0.14 & 37.91 & 0.00 & 0.56 & 16.81 & 2.50 \\
\hline BY 101 & IV & 0.23 & 38.24 & 0.00 & 0.91 & 17.14 & 1.38 \\
\hline
\end{tabular}


(Schneider, 1951, Long, 1967; Jungfleish, 1984). PUREX Plant was a major contributor of organic additions to the tank farm, via the use of tributyl phosphate and diluent used in the PUREX solvent extraction process. The waste fractionization cesium-strontium removal process operated in the B-Plant also used organic chemicals. Reports of selected organics estimated from these two main organic contributors processes are compared to the organic inventory estimates in SSTs developed in this report.

The amount of organics added to the tank farms from these two major contributors is listed in the tables below. The amount of organics going to the tank farms from the PUREX process is estimated to be 655,000 gallons to organic wash waste and about 2,000 gallons to high-level waste (Sederburg and Reddick 1994). Knowing the two components from the PUREX Process, tributyl phosphate and normal paraffin hydrocarbon, the distribution of the organics is converted to a TOC basis and shown in Table 5.10. The total estimated TOC added to the tank farm from the PUREX process is estimated to be $1500 \mathrm{MT}$.

Estimated quantity of organics added to the SSTs from the B-Plant have been provided from consumption records (Allen 1967). Assuming all organics were sent to the tank farms, the estimate of total mass of the four organic carbon species sent to the tank farms is $850 \mathrm{Mkg}$ for the B-Plant cesium-stontium removal process (Table 5.11).

The estimate of the TOC inventory in each SST is listed in Appendix K, based on the median estimate of TOC for each tank. The best estimate TOC concentrations for each SST, according to phase, were used to determine inventory values. The phase quantities in each of the 149 SSTs were based on Tank Farm Surveillance Reports (Hanlon 1994). Also, assumptions pertaining to the density of the phase are required. Density values were obtained for all three phases from the laboratory dataset as shown in Table 4.4. The results for the ANOVA inventory estimate are shown in Table 5.12, and estimate the amount of TOC to be 1057 MT.

The sum of the TOC admitted to the tank farms, from the reports for the B-Plant and the PUREX processes, is $2300 \mathrm{Mkg}$. The total estimated inventory of TOC in the SSTs using the ANOVA model is about

Table 5.10. Estimate of Organic Carbon Inventory to Tank Farm from B-Plant Consumption (Allen 1967)

\begin{tabular}{||l|c|c|c|c||}
\hline & Process & $\begin{array}{c}\text { Grams Moles } \\
\text { Added to Tank } \\
\text { Farm }\end{array}$ & $\begin{array}{c}\text { Grams Carbon } \\
\text { Mole }\end{array}$ & Mkg \\
\hline Hydroacetic Acid & B-Plant & $9.00 \mathrm{E}+06$ & 24 & 216 \\
\hline Citric Acid & B-Plant & $3.30 \mathrm{E}+06$ & 72 & 237.6 \\
\hline HEDTA & B-Plant & $2.70 \mathrm{E}+06$ & 120 & 324 \\
\hline EDTA & $\begin{array}{c}\text { B-Plant } \\
\text { B-Plant Total }\end{array}$ & $5.70 \mathrm{E}+05$ & 120 & 68.4 \\
\hline
\end{tabular}


Table 5.11. Estimate of Organic Carbon Added from PUREX Operation, 1955-1991

\begin{tabular}{||l|c|c|c|c|}
\hline \multicolumn{1}{|c|}{ Component } & $\begin{array}{c}\text { Gallons to Tank Farm } \\
\text { (Sederburg and Reddick 1994) }\end{array}$ & $\begin{array}{c}\text { Density of } \\
\text { Organic (g/ml) }\end{array}$ & $\begin{array}{c}\text { Weight Carbon/ } \\
\text { Weight Organic }\end{array}$ & $\begin{array}{c}\text { Mass of Carbon to Tank } \\
\text { Farms, (Mkg) }\end{array}$ \\
\hline $\begin{array}{l}\text { Tributyl Phosphate (Organic } \\
\text { Wash Waste) }\end{array}$ & 202,219 & 0.973 & 0.541 & 403 \\
\hline $\begin{array}{l}\text { Normal Paraffin } \\
\text { Hydrocarbon (Organic Wash } \\
\text { Waste) }\end{array}$ & 452,741 & 0.76 & 0.847 & 1,103 \\
\hline NPH to High-Level Waste & & 0.76 & 0.847 & 5 \\
\hline \begin{tabular}{l} 
Total from PUREX \\
\hline
\end{tabular}
\end{tabular}

Table 5.12. Estimated Distribution of Total Organic Carbon in 149 Single-Shell Tanks, Median Concentrations, ANOVA Technique

\begin{tabular}{||l|c|}
\hline \multicolumn{1}{|c|}{ Phase } & Estimated TOC (Mkg) \\
\hline Liquid & 186 \\
\hline Saltcake & 756 \\
\hline Sludge & 114 \\
\hline Total TOC & 1,057 \\
\hline
\end{tabular}

Table 5.13. Estimated Distribution of Total Organic Carbon in 149 Single-Shell Tanks Compared to PUREX and B-Plant Tank Additions

\begin{tabular}{||l|c|c||}
\hline \multicolumn{1}{|c|}{ Process } & $\begin{array}{c}\text { TOC Process } \\
\text { Additions (Mkg) }\end{array}$ & $\begin{array}{c}\text { TOC ANOVA } \\
\text { Estimation (Mkg) }\end{array}$ \\
\hline ANOVA Estimation & & 1,057 \\
\hline $\begin{array}{l}\text { B-Plant Addition Estimate from } \\
\text { Consumption Records }\end{array}$ & 846 & \\
\hline PUREX Process Estimate & 1,511 & \\
\hline Total TOC & 2,357 & 1,057 \\
\hline
\end{tabular}

1,000 Mkg. As shown in Table 5.13, the sum of the ANOVA model results is about $50 \%$ less than the estimated TOC from the two major organic tank farm processes identified. Reasons for the discrepancy include: TOC in the double-shell tanks is not inventoried; organic aging effects are unaccounted for; or assuming the total consumption of organic chemicals admitted to the tank farm is too conservative (B-Plant). 


\subsection{Comparison of Present Results to Organic Watchlist Tanks}

Single-shell tanks can be placed on the organics watchlist according to several potential safety conditions, including estimates for dry basis TOC. For the organic watchlist tanks, estimates in this report were converted to a dry basis using the methodology described in Appendix I. These estimates were compared to the existing estimates for these tanks according to previous analytic results (Schulz 1980), TRAC and the previous TOC study (Toth et al. 1994). Since the current study distinguishes each phase, each estimate is compared to the TOC estimate developed in this study for each phase. The comparison shown in Table 5.14 indicates generally the new estimates for TOC are less than the previous watchlist estimates.

Table 5.14. Comparison of TOC Estimates for Organic Watchlist Tanks

\begin{tabular}{|c|c|c|c|c|c|c|}
\hline $\begin{array}{l}\text { Watchlist } \\
\text { Tank No. }\end{array}$ & $\begin{array}{c}\text { Tank TOC, } \\
\text { (wt\%) Dry } \\
\text { Basis, TRAC }\end{array}$ & $\begin{array}{c}\text { Tank TOC, } \\
\text { (wt\%) (Dry } \\
\text { Basis), Schultz } \\
(1980) \\
\end{array}$ & $\begin{array}{c}\text { Tank TOC } \\
\text { (Dry Basis) } \\
\text { per Toth et al } \\
(1994) \\
\end{array}$ & $\begin{array}{c}\text { Current Study } \\
\text { \% TOC, Sludge } \\
\text { (Dry Basis) } \\
\end{array}$ & $\begin{array}{c}\text { Current Study } \\
\text { \% TOC, Saltcake } \\
\text { (Dry Basis) }\end{array}$ & $\begin{array}{l}\text { Current Study \% } \\
\text { TOC, Liquid (Dry } \\
\text { Basis), median }\end{array}$ \\
\hline A101 & 0 & 7.16 & 3.28 & 0.99 & 0.098 & 1.81 \\
\hline $\mathrm{A} \times 102$ & & 2.83 & 3.03 & 0.18 & 1.05 & 2.75 \\
\hline $\mathrm{B} 103$ & 3.17 & & & 0.15 & & \\
\hline $\mathrm{C} 102$ & & & & 0.18 & & 0.85 \\
\hline $\mathrm{C} 103^{(2)}$ & & & 7.12 & 0.54 & & 3.01 \\
\hline S102 & & 6.1 & & 0.17 & 0.51 & 2.29 \\
\hline$\$ 111$ & & 2.34 & & 0.17 & 0.475 & 0.82 \\
\hline SX103 & & 4.6 & 2.69 & 0.17 & 0.456 & 1.24 \\
\hline SX106 & 5.02 & 5.96 & 3.82 & 0.17 & 0.456 & 4.02 \\
\hline $\mathrm{T} 111$ & & & & 0.54 & & 1.21 \\
\hline $\mathrm{TX} 105$ & 4.94 & & & 0.41 & 0.437 & 1.48 \\
\hline TX118 & & 3.22 & & & 0.722 & 0.5 \\
\hline TY104 & & 2.8 & & 0.41 & & 0.57 \\
\hline $\mathrm{U} 103$ & & 3.38 & & 0.57 & 1.05 & 1.09 \\
\hline U105 & & 3.38 & 3.41 & 0.18 & 0.887 & 0.84 \\
\hline $\mathrm{U} 106$ & & 9.96 & 3.47 & 0.43 & 1.05 & 4.3 \\
\hline $\mathrm{U} 107$ & 4.81 & & & 0.18 & 0.89 & 0.84 \\
\hline U111 & & 3.65 & & 0.43 & 0.96 & 2.77 \\
\hline U203 & & & 3.01 & 0.18 & & 0.97 \\
\hline U204 & & & 3.01 & 0.16 & & 0.85 \\
\hline
\end{tabular}




\subsection{Conclusions and Recommendations}

This document provides estimates and confidence levels of TOC and moisture for each of the 149 Hanford SSTs, with a methodology of ranking that can be used to select additional SSTs for monitoring and/or measuring. The methodology makes use of chemical analysis information provided in tank process laboratory results and tank characterization reports. The methodology also makes use of weighted average statistical methodology and a tank grouping method based on the different types of wastes introduced into each SST (SORWT grouping technique). The data indicated a significant correlation of TOC values to waste phase (liquid, saltcake, and sludge). Therefore, waste phase dependence (saltcake, sludge, and liquid) was included in the statistical model for this study.

Characteristic reports and laboratory analytical results from 78 of the 149 SSTs were provided. Most of the reports provide data on the liquid phase TOC, but core composite, sludge, and saltcake data are also represented. Saltcake measurements are not well characterized. When saltcake data are reported, only one measurement since 1982 is represented. Saltcake was found to have the highest TOC content compared to the other two phases, sludges and liquids. Only 20 saltcake TOC measurements are recorded.

Although the TOC and moisture information compiled and modeled statistically in this report represents a significant improvement in our knowledge about TOC in SSTs, the dataset could be improved upon. Specifically, it is recommended that:

- available data be examined to determine if another analyte may be used as an indicator for high organic content;

- double-shell tank data be included in the model of TOC;

- distinction be made for the preparatory methods and analytical methods for water and TOC measurements;

- moisture sampling data, including liquid observation well probe readings, be investigated for use for the moisture ANOVA model;

- the data be grouped into families of SOWRT groups depending on knowledge of TOC content of waste types (the tank grouping scheme should be simplified);

- a TOC dataset be constructed that can be updated with additional TOC measurements as they become available; and

- the availability of information on TOC and moisture spatial variations (riser/core information) be determined (include spatial variations in the statistical model). 


\subsection{References}

Allen, G. K. 1967. Estimated Inventory of Chemicals Added to Underground Waste Tanks, 1944 through 1975. ARC-CD-610B, Atlantic Richfield Hanford Company, Richland, Washington.

Anderson, J. D. 1990. A History of the 200 Area Tank Farms. WHC-MR-0132, Westinghouse Hanford Company, Richland, Washington.

Babad, H., and D. A. Turner. September 1993. Interim Criteria for Organic Watch List Tanks at the Hanford Site. WHC-EP-0681, Westinghouse Hanford Company, Richland, Washington.

Campbell, M. H., and M. J. Kupfer. 1974. ARCO Quarterly Report, Waste Management and Transportation Technology Development, July through September, 1974. ARH-ST-110 A. Richland, Washington.

Corbeil, R. R., and S: R. Searle. 1976. "Restricted Maximum Likelihood (REML) Estimation of Variance Components in the Mixed Model" Technometrics, Vol. 18, No. 1.

Crowe, R. D., and D. L. Heer. 1992. Potential of Estimating Moisture Content in Waste Tanks Using the Existing Neutron Probe. WHC-SD-WM-RPT-037, Westinghouse Hanford Company, Richland, Washington.

Fisher, F. D. 1990. The Kyshtym Explosion and Explosion Hazards with Nitrate - Nitrite Bearing Waste with Acetates and Other Organic Salts. WHC-SD-CP-LB-033, Westinghouse Hanford Company, Richland, Washington.

Gerber, M. A. October 1994. Waste Tank Organic Safety Project Organic Concentration Mechanisms Task FY 1994 Progress Report, PNL-10064, Pacific Northwest Laboratory, Richland, Washington.

Hanlon, B. M. 1994a. Tank Farm Surveillance and Waste Status Summary Report for February, 1994. WHC-EP-0182-71, Westinghouse Hanford Company, Richland, Washington.

Hanlon, B. M. 1994b. Tank Farm Surveillance and Waste Status Summary Report for March, 1994. WHC-EP-0182-72, Westinghouse Hanford Company, Richland, Washington.

Herting, D. L. et al. 1992. 1992 Tank 101-SY Characterization Report. WHC-SD-WM-DTR-026, Westinghouse Hanford Company, Richland, Washington.

Hill, J. G., and B. C. Simpson. August 1994. The Sort on Radioactive Waste Type Model: A Method to Sort Single Shell Tanks Into Characteristic Groups. PNL-9814 Rev. 1, draft for review comment. Pacific Northwest Laboratory, Richland, Washington.

Hill, J. G., G. S. Anderson, and B. C. Simpson. March 1995. The Sort on Radioactive Waste Type Model: A Method to Sort Single-shell Tanks Into Characteristic Groups. PNL-9814, Rev. 2, Pacific Northwest Laboratory Richland Washington. 
Jensen, L. 1993. Characterization Report for Single-Shell Tank 241-U-110. WHC-SD-WM-TI-560, Rev. 0, Westinghouse Hanford Company, Richland, Washington.

Jungfleisch, F. M. 1984. Preliminary Estimation of the Waste Inventories in Hanford Tanks Through 1980. SD-WM-TI-057, Rockwell Hanford Operations, Richland, Washington.

Long, J. T. 1967. Engineering for Nuclear Fuel Reprocessing. Gordon and Breach Science Publishers Inc. LCCC 66-28071, New York, New York.

Schulz, W. W. 1980. Removal of Radionuclides from Hanford Defense Waste Solutions. RHO-SA-51, Rockwell Hanford Operations, Richland, Washington.

Schneider, K. J. 1951. Flow Sheets and Flow Diagrams of Precipitation Separations Process, HW-23043, General Electric Company, Richland, Washington.

Sederburg, J. P. and J. A. Reddick. TBP and Diluent Mass Balances in the Purex Plant at Hanford 1955-1991, WHC-MR-0483 Rev. 0, Westinghouse Hanford Company, Richland, Washington.

Toth, J. J., C. E. Willingham, P. G. Healser, and P. D. Whitney. 1994. Organic Carbon in Hanford Single-Shell Tank Waste, PNL-9434, Pacific Northwest Laboratory, Richland, Washington.

Toth, J. J., C. E. Willingham, P. G. Heasler, and P. D. Whitney. 1995. Organic Carbon in Hanford Single-Shell Tank Waste, PNL-9434 Rev. 1, Pacific Northwest Laboratory, Richland, Washington.

Webb, A. L, J. L. Stewart, M. G. Plys, B. Malinovuic, J. M. Grigsby, D. M. Camaioni, P. G. Heasler, and J. J. Toth. 1995. Preliminary Safety Criteria for Organic Watchlist Tanks at the Hanford Site, WHC-SD-SARR-033 Rev. 0, Westinghouse Hanford Company, Richland, Washington. 
Appendix A

Phase Inventory for 149 Single-Shell Tanks 
Phase Inventory for 149 Single Shell Tanks

\begin{tabular}{|c|c|c|c|c|c|c|c|}
\hline $\begin{array}{l}\text { Tank } \\
\text { Number }\end{array}$ & $\begin{array}{l}\text { Total } \\
\text { Liquid } \\
\text { Volume, KGal }\end{array}$ & $\begin{array}{l}\text { Tank } \\
\text { Number }\end{array}$ & $\begin{array}{l}\text { Total } \\
\text { Liquid } \\
\text { Volume, KGal }\end{array}$ & $\begin{array}{l}\text { Tank } \\
\text { Number }\end{array}$ & $\begin{array}{l}\text { Total } \\
\text { Liquid } \\
\text { Volume KGal }\end{array}$ & $\begin{array}{l}\text { Tank } \\
\text { Number }\end{array}$ & $\begin{array}{l}\text { Total Liquid } \\
\text { Volume , Kgal }\end{array}$ \\
\hline $\mathrm{Al01}$ & 413 & BX112 & 8 & S112 & 110 & TX107 & 2 \\
\hline $\mathrm{A} 102$ & 6 & BY101 & 5 & SX101 & 146 & TX109 & 10 \\
\hline A103 & 20 & BY102 & 41 & $\mathrm{~S} \times 102$ & 183 & TX110 & 15 \\
\hline A105 & 4 & BY103 & 160 & SX103. & 233 & $\mathrm{TX} 111$ & 9 \\
\hline Al06 & 7 & BY104 & 18 & SX104 & 201 & $\mathrm{TX} 112$ & 24 \\
\hline AX101 & 320 & BY 105 & 192 & SX105 & 261 & $\mathrm{TX} 113$ & 16 \\
\hline $\mathrm{AX} 102$ & 17 & BY 106 & 235 & SX106 & 255 & TX114 & 15 \\
\hline AX103 & 36 & BY 107 & 25 & SX107 & 5 & $\mathrm{TX} 115$ & 19 \\
\hline $\mathrm{B} 101$ & 6 & BY 108 & 9 & SX108. & 5 & $\mathrm{TX} 116$ & 23 \\
\hline B102 & 4 & BY 109 & 78 & SX109 & 10 & TX117 & 8 \\
\hline B104 & 47 & BY 110 & 9 & SX111 & 7 & TX118 & 27 \\
\hline B 105 & 23 & BY 112 & 8 & SX112 & 3 & TY102 & 14 \\
\hline B106 & 7 & C101 & 3 & SX114 & 14 & TY103 & 5 \\
\hline B107 & 13 & $\mathrm{C} 102$ & 37 & $\mathrm{~T} 101$ & 17 & TY 104 & 15 \\
\hline $\mathrm{B} 108$ & 4 & C103 & 133 & T102 & 13 & U101 & 3 \\
\hline B109 & 8 & C104 & 11 & T103 & 4 & U 102 & 144 \\
\hline$B 110$ & 23 & C105 & 11 & T104 & 50 & U103 & 189 \\
\hline B111 & 22 & C106 & 48 & T105 & 23 & U104 & 7 \\
\hline B112 & 3 & C107 & 26 & T106 & 2 & U105 & 179 \\
\hline B201 & 4 & C109 & 4 & T107 & 22 & U106 & 83 \\
\hline B202 & 3 & C110 & 7 & T110 & 42 & U107 & 178 \\
\hline B203 & 6 & $\mathrm{C} 112$ & 32 & $\mathrm{~T} 111$ & 51 & U108 & 196 \\
\hline B204 & 6 & S101 & 96 & $\mathrm{~T} 112$ & 7 & U109 & 182 \\
\hline $\mathrm{BX} 101$ & 1 & $S 102$ & 230 & T201 & 4 & U110 & 15 \\
\hline BX102 & 4 & $S 103$ & 102 & T202 & 2 & U111 & 122 \\
\hline BX103 & 4 & S104 & 29 & T203 & 4 & U112 & 4 \\
\hline BX104 & 33 & S105 & 35 & T204 & 4 & U201 & 1 \\
\hline $\mathrm{BX} 105$ & 11 & S106 & 190 & TX101 & 5 & U202 & 1 \\
\hline BX106 & 15 & S107 & 59 & TX102 & 22 & U203 & 1 \\
\hline BX107 & 30 & S108 & 127 & TX103 & 15 & U204 & 1 \\
\hline $\mathrm{BX} 108$ & 1 & $S 109$ & 141 & TX104 & 15 & & \\
\hline BX109 & 13 & $S 110$ & 110 & TX105 & 20 & & \\
\hline BX 110 & 15 & S111 & 205 & TX106 & 10 & & \\
\hline
\end{tabular}

Note: Tanks without inventory are not listed. 
Phase Inventory for 149 Single- Shell Tanks

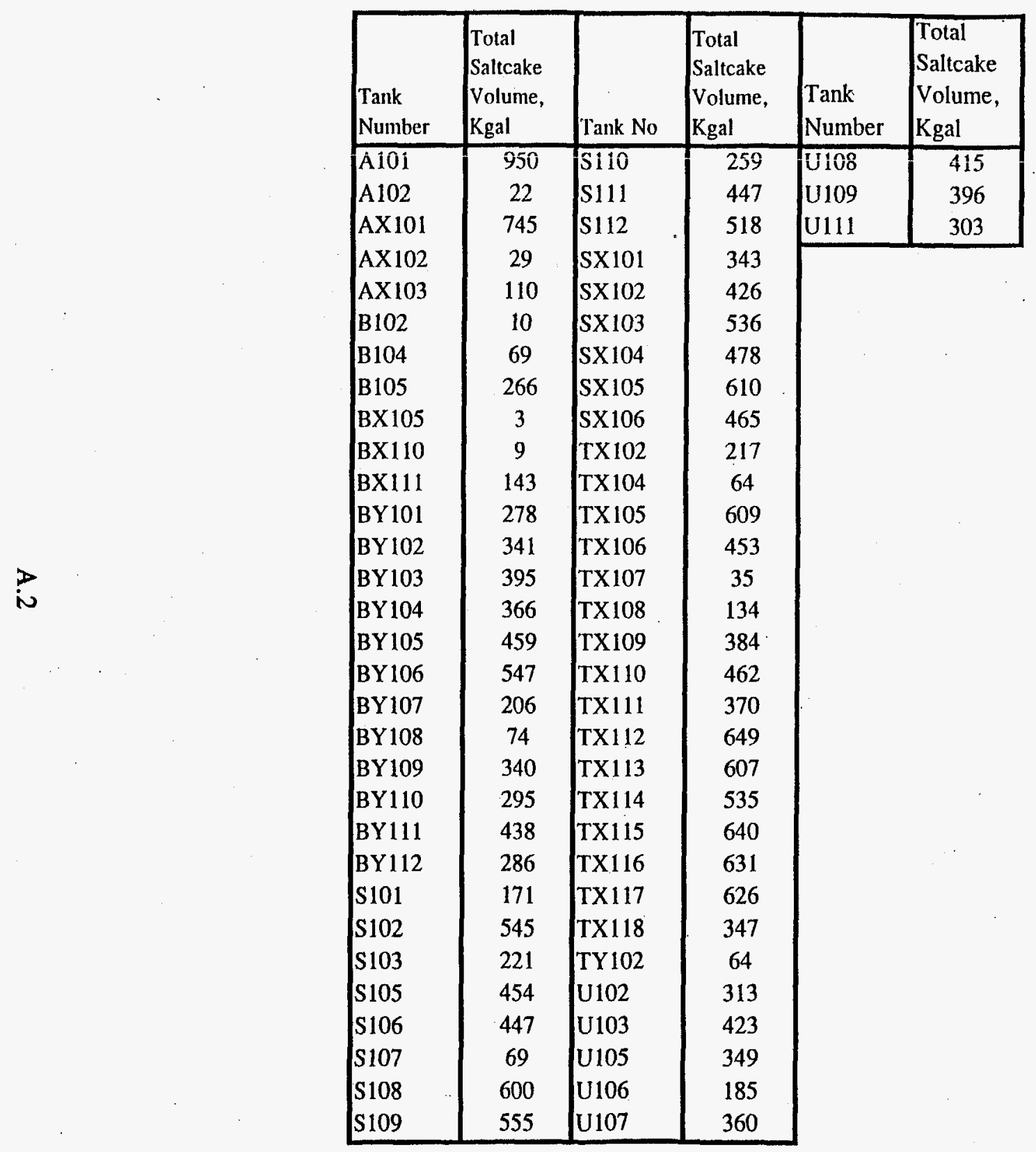

Note: Tanks without inventory are not listed. 


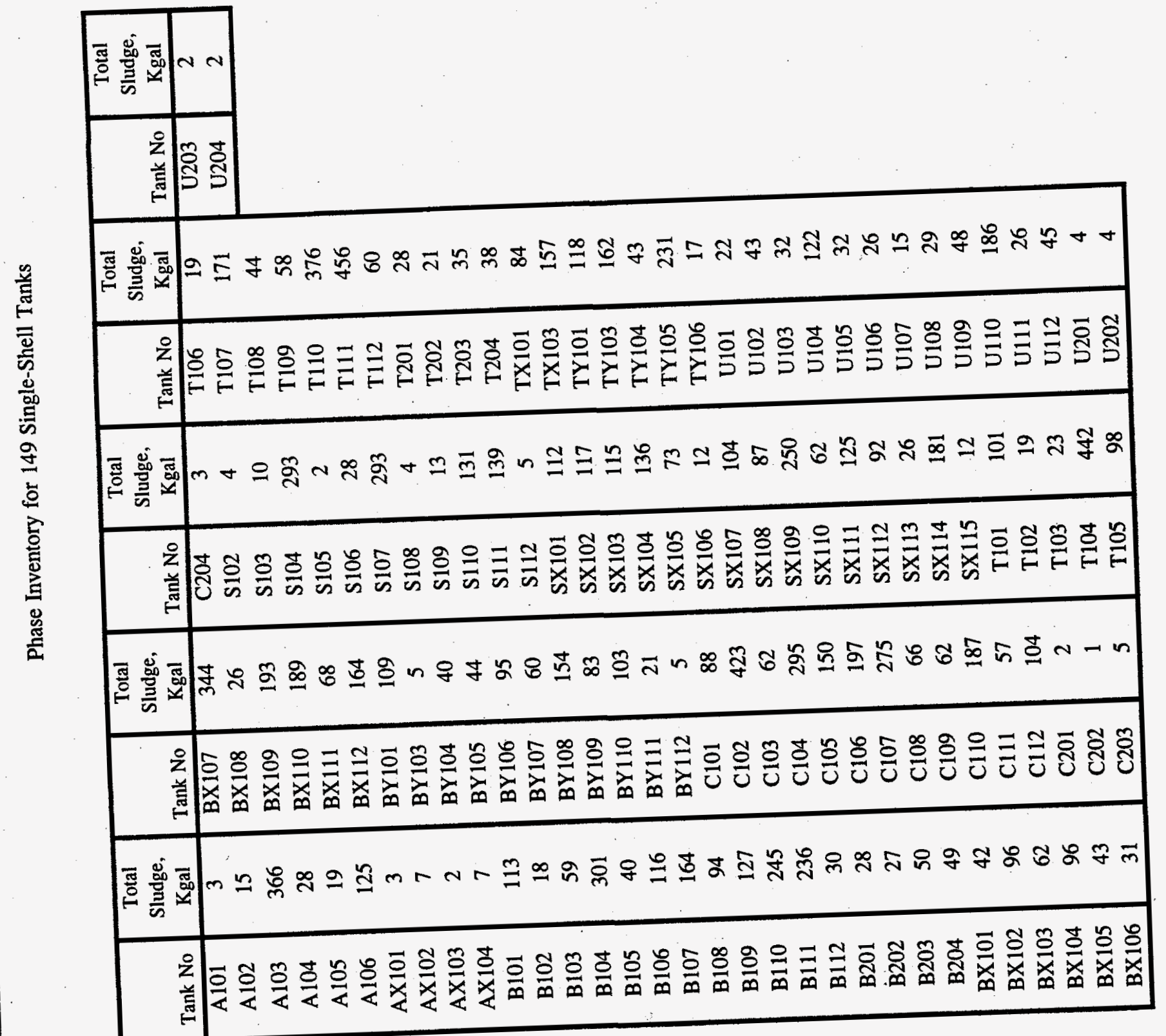




\section{Appendix B}

\section{Nominal Characteristics of Each Phase}


Appendix B - Analysis of Phase Characteristics

\section{B.1 Analysis of Variance}

TUE 9/20/94 1:44:38 PM D:ITOCITOCLOCK.SYS

LEVELS ENCOUNTERED DURING PROCESSING ARE:

NEWPHASE\$

Liquid

Saltcake Sludge

113 CASES DELETED DUE TO MISSING DATA.

DEP VAR: LOGTOC N: 358 MULTIPLE R: 0.431 SQUAREO MULTIPLE R: 0.186

ESTIMATES OF EFFECTS $B=\left(X^{\prime} X\right)^{-1} X^{\prime} Y$

LOGTOC

$\begin{array}{lll}\text { CONSTANT } & & 3.495 \\ \text { NEWPHASES } & \text { Liquid } & 0.074 \\ \text { NEWPHASE\$ Saltcake } & 0.276\end{array}$

ANALYSIS OF VARIANCE

$\begin{array}{lccccc}\text { SOURCE } & \text { SUM-OF-SQUARES } & \text { DF } & \text { MEAN-SQUARE } & \text { F-RATIO } & P \\ \text { NEWPHASES } & 18.870 & 2 & 9.435 & 40.575 & 0.000 \\ \text { ERROR } & 82.549 & 355 & 0.233 & & \end{array}$

LEAST SQUARES MEANS.

$\begin{array}{llrrr}\text { NEWPHASES } & \text { Liquid } & \text { LS MEAN } & \text { SE } & \text { N } \\ \text { NEWPHASES } & =\text { Saltcake } & 3.569 & 0.040 & 142 \\ \text { NEWPHASES } & =\text { Siudge } & 3.771 & 0.103 & 22 \\ & 3.145 & 0.035 & 194\end{array}$

TUE 9/20/94 1:45:54 PM D:ITOCITOCLOCK.SYS

COLI

ROWNEWPHASE\$

1 Liquid

2 Saltcake

3 Sludge

USING LEAST SQUARES MEANS.

POST HOC TEST OF LOGTOC

USING MODEL MSE OF 233 WITH 355. DF. MATRIX OF PAIRWISE MEAN DIFFERENCES:

$\begin{array}{llll} & 1 & 2 & 3 \\ 1 & 0.000 & & \\ 2 & 0.202 & 0.000 & \\ 3 & -0.424 & -0.626 & 0.000\end{array}$

TUKEY HSD MULTIPLE COMPARISONS.

MATRIX OF PAIRWISE COMPARISON PROBABILITIES:

$\begin{array}{llll} & 1 & 2 & 3 \\ 1 & 1.000 & & \\ 2 & 0.161 & 1.000 & \\ 3 & 0.000 & 0.000 & 1.000\end{array}$

B.1 


\section{B.2 Nominal Characteristics of Phases}

TUE 9/20/94 1:47:06 PM D:ITOCITOCLOCK.SYS

THE FOLLOWING RESULTS ARE FOR:

NEWPHASES = Liquid

TOTAL OBSERVATIONS: 147

\begin{tabular}{|c|c|c|c|c|}
\hline & TOCUGG & LOGTOC & GML & $\mathrm{H} 2 \mathrm{O}$ \\
\hline $\begin{array}{l}\text { N OF CASES } \\
\text { MINIMUM } \\
\text { MAXIMUM } \\
\text { RANGE } \\
\text { MEAN } \\
\text { VARIANCE } \\
\text { STANDARD DEV } \\
\text { STD. ERROR } \\
\text { SKEWNESS(GI) } \\
\text { KURTOSIS(G2) } \\
\text { SUM } \\
\text { C. V. } \\
\text { MEDIAN }\end{array}$ & $\begin{array}{r}143 \\
0.000 \\
99600.000 \\
99600.000 \\
7040.272 \\
136633 . \mathrm{E}+09 \\
11689.009 \\
977.484 \\
4.878 \\
30.018 \\
1006758.897 \\
1.660 \\
3840.000\end{array}$ & $\begin{array}{r}142 \\
1.980 \\
4.998 \\
3.018 \\
3.569 \\
0.248 \\
0.498 \\
0.042 \\
-0.242 \\
0.968 \\
506.770 \\
0.140 \\
3.585\end{array}$ & $\begin{array}{r}43 \\
1.020 \\
1.970 \\
0.950 \\
1.370 \\
0.040 \\
0.199 \\
0.030 \\
0.553 \\
1.024 \\
58.898 \\
0.145 \\
1.378\end{array}$ & $\begin{array}{r}36 \\
34.000 \\
96.480 \\
62.480 \\
55.669 \\
249.079 \\
15.782 \\
2.630 \\
1.328 \\
1.081 \\
2004.070 \\
0.284 \\
50.850\end{array}$ \\
\hline
\end{tabular}

THE FOLLOWING RESULTS ARE FOR: NEWPHASES = Saltcake

TOTAL OBSERVATIONS: 23

\begin{tabular}{|c|c|c|c|c|}
\hline & TOCUGG & LOGTOC & GML & $\mathrm{H} 2 \mathrm{O}$ \\
\hline $\begin{array}{l}\text { N OF CASES } \\
\text { MINIMUM } \\
\text { MAXIMUM } \\
\text { RANGE } \\
\text { MEAN } \\
\text { VARIANCE } \\
\text { STANDARD DEV } \\
\text { STD. ERROR } \\
\text { SKEWNESS(G1) } \\
\text { KURTOSIS (G2) } \\
\text { SUM } \\
\text { C.V. } \\
\text { MEDIAN }\end{array}$ & $\begin{array}{r}22 \\
470.000 \\
56296.875 \\
55826.875 \\
11259.672 \\
.181096 \mathrm{E}+09 \\
13457.193 \\
2869.083 \\
2.038 \\
3.910 \\
247712.791 \\
1.195 \\
7083.601\end{array}$ & $\begin{array}{r}22 \\
2.672 \\
4.750 \\
2.078 \\
3.771 \\
0.299 \\
0.547 \\
0.117 \\
-0.260 \\
-0.601 \\
82.954 \\
0.145 \\
3.845\end{array}$ & $\begin{array}{r}8 \\
1.270 \\
2.000 \\
0.730 \\
1.635 \\
0.062 \\
0.249 \\
0.088 \\
0.083 \\
-1.201 \\
13.080 \\
0.153 \\
1.600\end{array}$ & $\begin{array}{r}13 \\
10.700 \\
53.700 \\
43.000 \\
25.692 \\
177.734 \\
13.332 \\
3.698 \\
0.801 \\
-0.625 \\
334.000 \\
0.519 \\
18.100\end{array}$ \\
\hline
\end{tabular}

THE FOLLOWING RESULTS ARE FOR: NEWPHASE\$ = Siudge

TOTAL OBSERVATIONS: 301

\begin{tabular}{lrrrr} 
& \multicolumn{1}{c}{ TOCUGG } & \multicolumn{1}{c}{ LOGTOC } & \multicolumn{1}{c}{ GML } & \multicolumn{1}{c}{ H20 } \\
N OF CASES & 202 & 194 & 77 & 115 \\
MINIMUM & 20.000 & 1.602 & 1.000 & 3.080 \\
MAXIMUM & 33200.000 & 4.521 & 1.930 & 95.600 \\
RANGE & 33180.000 & 2.919 & 0.930 & 92.520 \\
MEAN & 2584.570 & 3.145 & 1.451 & 43.205 \\
VARIANCE & $.212291 E+08$ & 0.214 & 0.043 & 216.909 \\
STANDARD DEV & 4607.510 & 0.462 & 0.208 & 14.728 \\
STD. ERROR & 324.183 & 0.033 & 0.024 & 1.373 \\
SKEWNESS(G1) & 5.010 & 0.315 & 0.103 & -0.473 \\
KURTOSIS(G2) & 28.057 & 0.596 & -0.060 & 2.210 \\
SUM & 522083.190 & 610.064 & 111.764 & 4968.580 \\
C.V. & 1.783 & 0.147 & 0.143 & 0.341 \\
MEDIAN & 1205.000 & 3.095 & 1.460 & 43.500
\end{tabular}


SUMMARY STATISTICS FOR TOCUGG

BARTLETT TEST FOR HOMOGENEITY OF GROUP VARIANCES

CHI-SQUARE $=150.855$ DF $=2$ PROBABILITY $=0.000$

ANALYSIS OF VARIANCE

SOURCE SUM OF SQUARES DF MEAN SQUARE F PROBABILITY

BETWEEN GROUPS $.262653 E+10 \quad 2 \quad .131326 \mathrm{E}+10 \quad .17 .401 \quad 0.000$ $\begin{array}{lllll}\text { WITHIN GROUPS } & .274720 E+11 & 364 & .754724 E+08\end{array}$

SUMMARY STATISTICS FOR LOGTOC

BARTLETT TEST FOR HOMOGENEITY OF GROUP VARIANCES

CHI-SQUARE =

1.687 DF= 2 PROBABILITY =

0.430

ANALYSIS OF VARIANCE

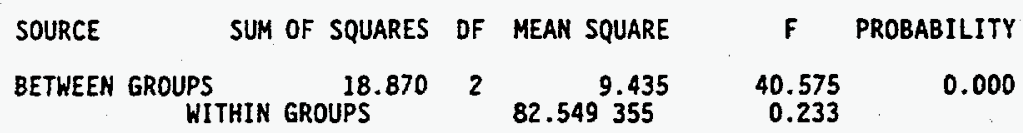

SUMMARY STATISTICS FOR GML

BARTLETT TEST FOR HOMOGENEITY OF GROUP VARIANCES

CHI-SQUARE $=0.656$ DF $=2$ PROBABILITY $=0.720$

ANALYSIS OF VARIANCE

$\begin{array}{lrrrrr}\text { SOURCE } & \text { SUM OF SQUARES } & \text { DF } & \text { MEAN SQUARE } & \text { F } & \text { PROBABILITY } \\ \text { BETWEEN GROUPS } & 0.524 & 2 & 0.262 & 6.091 & 0.003 \\ \text { WITHIN GROUPS } & & 5.378125 & 0.043 & \end{array}$

SUMMARY STATISTICS FOR H2O

BARTLETT TEST FOR HOMOGENEITY OF GROUP VARIANCES

CHI-SQUARE =

0.535 DF $=2$ PROBABILITY *

0.765

ANALYSIS OF VARIANCE

SOURCE

SUM OF SQUARES DF MEAN SQUARE

- $F$ PROBABILITY

BETHEEN GROUPS

9281.43324640 .716 35578.200161

21.000

220.983

0.000 WITHIN GROUPS

B.3 


\section{B.3 Confidence Intervals for Phases}

\section{B.3.1 TOC}

TUE 9/20/94 1:50:00 PM D:ITOCITOCLOCK.SYS

THE FOLLOWING RESULTS ARE FOR:

$$
\text { NEWPHASES = Liquid }
$$

ITERATION LOSS PARAMETER YALUES

$$
\begin{array}{lll}
0 & .1743655 D+04 & .1000 D+00 \\
1 & .3502766 D+02 & .35690+01 \\
2 & .3502766 D+02 & .35690+01 \\
3 & .3502766 D+02 & .3569 D+01
\end{array}
$$

DEPENDENT VARIABLE IS LOGTOC

MISSING DATA OR ESTIMATES REDUCED DEGREES OF FREEDOM

\begin{tabular}{|c|c|c|c|}
\hline $\begin{array}{l}\text { REGRESSION } \\
\text { RESIDUAL }\end{array}$ & $\begin{array}{r}1808.561 \\
35.028\end{array}$ & 141 & $\begin{array}{r}1808.561 \\
0.248\end{array}$ \\
\hline CORF & & $\begin{array}{l}.588 \\
.028\end{array}$ & $\begin{array}{l}142 \\
141\end{array}$ \\
\hline
\end{tabular}

SOURCE SUM-OF-SQUARES DF MEAN-SQUARE

RAW R-SQUARED (1-RESIDUAL/TOTAL) $=0.981$ CORRECTED R-SQUARED (1-RESIDUAL/CORRECTED) $=0.000$

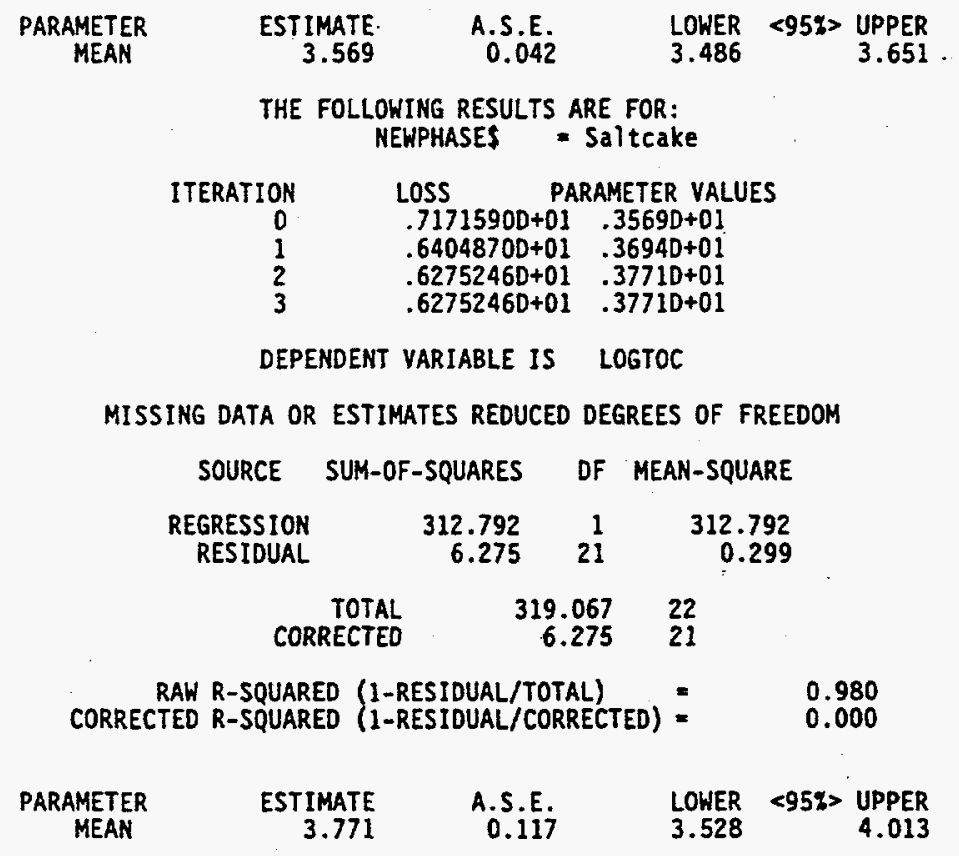


THE FOLLOWING RESULTS ARE FOR:

NEWPHASES = Sludge

ITERATION LOSS PARAMETER VALUES

$\begin{array}{lll}0 & .11726770+03 & .37710+01 \\ 1 & .41246240+02 & .3145 D+01 \\ 2 & .41246240+02 & .31450+01 \\ 3 & .41246240+02 & .3145 D+01\end{array}$

DEPENDENT VARIABLE IS LOGTOC

MISSING DATA OR ESTIMATES REDUCED DEGREES OF FREEDOM

SOURCE SUM-OF-SQUARES , DF MEAN-SQUARE

$\begin{array}{rrrr}\text { REGRESSION } & 1918.444 & 1 & 1918.444 \\ \text { RESIDUAL } & 41.246 & 193 & 0.214\end{array}$

TOTAL $\quad 1959.691 \quad 194$

$\begin{array}{lrr} & 1959.691 & 194 \\ \text { CORRECTED } & 41.246 \quad 193\end{array}$

RAW R-SQUARED (1-RESIOUAL/TOTAL) $=0.979$

CORRECTED R-SQUARED (1-RESIDUAL/CORRECTED) $=0.000$

$\begin{array}{crrrr}\text { PARAMETER } & \text { ESTIMATE } & \text { A.S.E. } & \text { LOWER } & <95 \%>\text { UPPER } \\ \text { MEAN } & 3.145 & 0.033 & 3.079 & 3.210\end{array}$

B.3.2 Weight $\%$ Water

TUE 9/20/94 2:35:38 PM D:ITOCITOCLOCK.SYS

THE FOLLOWING RESULTS ARE FOR: NEWPHASES - Liquid

ITERATION LOSS PARAMETER VALUES

$\begin{array}{lll}0 & .11988110+06 & .1000 D+00 \\ 1 & .79862100+05 & .10010+03 \\ 2 & .98295460+04 & .5011 D+02 \\ 3 & .87177630+04 & .5567 D+02 \\ 4 & .87177630+04 & .55670+02 \\ 5 & .87177630+04 & .55670+02\end{array}$

DEPENDENT YARIABLE IS H2O

MISSING DATA OR ESTIMATES REDUCED DEGREES OF FREEDOM

SOURCE SUM-OF-SQUARES DF MEAN-SQUARE

$\begin{array}{rrrr}\text { REGRESSION } & 111563.786 & 1 & 111563.786 \\ \text { RESIDUAL } & 8717.763 & 35 & 249.079\end{array}$

TOTAL $120281.556 \quad 36$

CORRECTED $\quad 8717.763 \cdot 35$

RAW R-SQUARED (1-RESIDUAL/TOTAL) $=0.928$

CORRECTED R-SQUARED (1-RESIDUAL/CORRECTED) $=0.000$

PARAMETER ESTIMATE A.S.E. LOWER <95\%> UPPER

MEAN $\quad 55.669 \quad 2.630 \quad 50.329 \quad 62.009$ 
THE FOLLOWING RESULTS ARE FOR: NEWPHASE\$ = Saltcake

\begin{tabular}{cll} 
ITERATION & LOSS & \multicolumn{2}{c}{ PARAMETER VALUES } \\
0 & $.13814340+05$ & $.55670+02$ \\
1 & $.30717460+04$ & $.34190+02$ \\
2 & $.21328110+04$ & $.25690+02$ \\
3 & $.21328110+04$ & $.25690+02$
\end{tabular}

DEPENDENT VARIABLE IS H2O

MISSING DATA OR ESTIMATES REDUCED DEGREES OF FREEDOM

SOURCE SUM-OF-SQUARES DF MEAN-SQUARE

\begin{tabular}{|c|c|c|c|}
\hline $\begin{array}{l}\text { REGRESSION } \\
\text { RESIDUAL }\end{array}$ & $\begin{array}{l}8581.231 \\
2132.811\end{array}$ & 12 & $\begin{array}{r}8581.231 \\
177.734\end{array}$ \\
\hline CORI & & & $\begin{array}{l}13 \\
12\end{array}$ \\
\hline
\end{tabular}

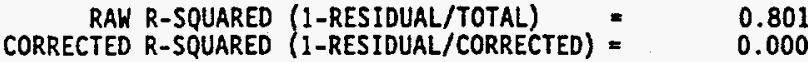

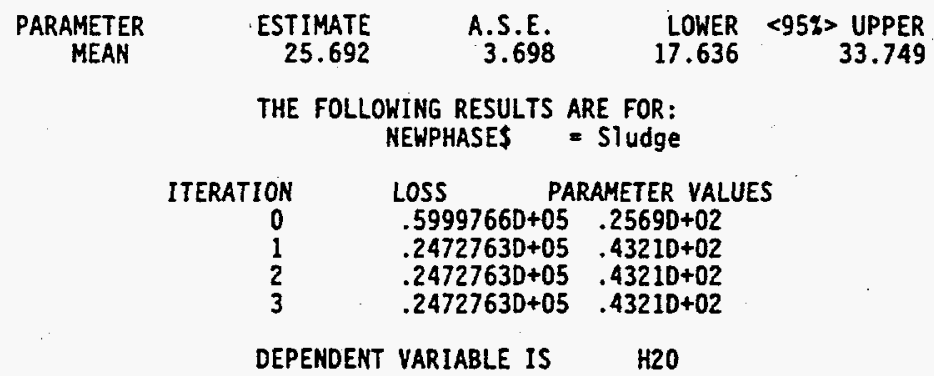

MISSING DATA OR ESTIMATES REDUCED DEGREES OF FREEDOM

SOURCE SUM-OF-SQUARES DF MEAN-SQUARE

$\begin{array}{crrr}\text { REGRESSION } & 214667.701 & 1 & 214667.701 \\ \text { RESIDUAL } & 24727.626 & 114 & 216.909 \\ & \text { TOTAL } & 239395.341 & 115 \\ \text { CORRECTED } & 24727.626 & 114\end{array}$

RAW R-SQUARED (1-RESIDUAL/TOTAL) = $=0.897$ CORRECTED R-SQUARED (1-RESIDUAL/CORRECTED) $=0.000$

$\begin{array}{crrrr}\text { PARAMETER } & \text { ESTIMATE } & \text { A.S.E. } & \text { LOWER } & <95 \%>\text { UPPER } \\ \text { MEAN } & 43.205 & 1.373 & 40.484 & 45.926\end{array}$

B.6 


\section{B.3.3 Density}

THE FOLLOWING RESULTS ARE FOR:

$$
\text { NEWPHASES }=\text { Liquid }
$$

ITERATION LOSS PARAMETER VALUES

$\begin{array}{lll}0 & .70990590+02 & .1000 D+00 \\ 1 & .16653530+01 & .13700+01\end{array}$

$\begin{array}{rr}.16653530+01 & .13700+01 \\ 16653530+01 & .13700+01\end{array}$

$2 \quad .16653530+01$

MISSING DATA OR ESTIMATES REDUCED DEGREES OF FREEDOM

$$
\begin{aligned}
& \text { SOURCE SUM-OF-SQUARES DF MEAN-SQUARE } \\
& \begin{array}{rrrr}
\text { REGRESSION } & 80.675 & 1 & 80.675 \\
\text { RESIDUAL } & 1.665 & 42 & 0.040
\end{array} \\
& \begin{array}{rrr}
\text { TOTAL } & 82.340 & 43 \\
& 1.665 & 42
\end{array} \\
& \text { RAW R-SOUARED (1-RESIDUAL/TOTAL) }=0.980 \\
& \text { CORRECTED R-SQUARED (1-RESIDUAL/CORRECTED) }=0.000 \\
& \begin{array}{crrrr}
\text { PARAMETER } & \text { ESTIMATE. } & \text { A.S.E. } & \text { LOWER } & <95 \%>\text { UPPER } \\
\text { MEAN } & 1.370 & 0.030 & 1.308 & 1.431
\end{array} \\
& \text { NEWPHASES = Saltcake } \\
& \text { ITERATION LOSS PARAMETER VALUES } \\
& 0 \quad .99814440+00.1370 D+01 \\
& 1 \quad .47203950+00 \quad .15670+01 \\
& .43520000+00 \quad .16350+01 \\
& \begin{array}{lll}
3 & .43520000+00 & .16350+01 \\
4 & .43520000+00 & .16350+01
\end{array}
\end{aligned}
$$

MISSING DATA OR ESTIMATES REDUCED DEGREES OF FREEDOM

$$
\text { SOURCE SUM-OF-SQUARES DF MEAN-SQUARE }
$$

$$
\begin{aligned}
& \begin{array}{rrrr}
\text { REGRESSION } & 21.386 & 1 & 21.386 \\
\text { RESIDUAL } & 0.435 & 7 & 0.062
\end{array} \\
& \begin{array}{rrr}
\text { TOTAL } & 21.821 & 8 \\
\text { CORRECTED } & 0.435 & 7
\end{array} \\
& \text { RAW R-SQUARED (1-RESIDUAL/TOTAL) }=0.980 \\
& \text { CORRECTED R-SQUARED (1-RESIDUAL/CORRECTED) }=0.000 \\
& \begin{array}{crrrr}
\text { PARAMETER } & \text { ESTIMATE } & \text { A.S.E. } & \text { LOWER } & <95 \%>\text { UPPER } \\
\text { MEAN } & 1.635 & 0.088 & 1.427 & 1.843
\end{array} \\
& \text { THE FOLLOWING RESULTS ARE FOR: } \\
& \text { NEWPHASES = Sludge } \\
& \text { ITERATION - LOSS PARAMETER VALUES } \\
& \begin{array}{lll}
0 & .58706430+01 & .16350+01 \\
1 & .32773290+01 & .14510+01
\end{array} \\
& \begin{array}{lll}
1 & .32773290+01 & .14510+01 \\
& .32773290+01 & .14510+01
\end{array}
\end{aligned}
$$

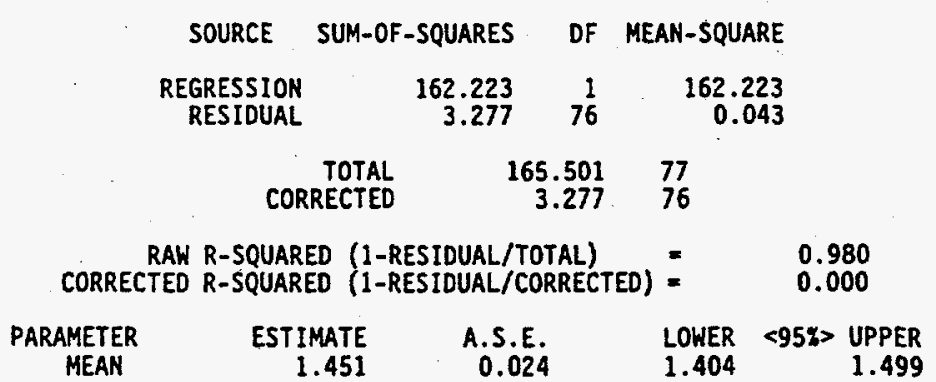

B.7 
Appendix C

Descriptive Tank Statistics by Sort on Radioactive Waste Type 


\section{C.1 - Liquid Phase}

TUE 9/20/94 2:54:05 PM D: ITOCITOCLOCK.SYS

THE FOLLOWING RESULTS ARE FOR:

SORWTGROS = I

TOTAL OBSERVATIONS: 29

\begin{tabular}{|c|c|c|c|c|}
\hline & TOCUGG & LOGTOC & GML & $\mathrm{H} 2 \mathrm{O}$ \\
\hline $\begin{array}{l}\text { N OF CASES } \\
\text { MINIMUM } \\
\text { MAXIMUM } \\
\text { RANGE } \\
\text { MEAN } \\
\text { VARIANCE } \\
\text { STANDARD DEV } \\
\text { STO. ERROR } \\
\text { SKEWNESS(G1) } \\
\text { KURTOSIS(G2) } \\
\text { SUM } \\
\text { C.V. } \\
\text { MEDIAN }\end{array}$ & $\begin{array}{r}28 \\
288.288 \\
59611.679 \\
59323.391 \\
8823.890 \\
193944 \mathrm{E}+09 \\
13926.374 \\
2631.837 \\
2.813 \\
6.897 \\
247068.906 \\
1.578 \\
3924.915\end{array}$ & $\begin{array}{r}28 \\
2.460 \\
4.775 \\
2.316 \\
3.651 \\
0.241 \\
0.491 \\
0.093 \\
0.228 \\
0.739 \\
102.214 \\
0.135 \\
3.594\end{array}$ & $\begin{array}{r}15 \\
1.020 \\
1.970 \\
0.950 \\
1.387 \\
0.080 \\
0.282 \\
0.073 \\
0.549 \\
-0.487 \\
20.811 \\
0.203 \\
1.400\end{array}$ & $\begin{array}{r}10 \\
41.650 \\
96.480 \\
54.830 \\
60.675 \\
376.214 \\
19.396 \\
6.134 \\
1.073 \\
-0.288 \\
606.750 \\
0.320 \\
54.820\end{array}$ \\
\hline
\end{tabular}

THE FOLLOWING RESULTS ARE FOR:

SORWTGROS = II

TOTAL OBSERVATIONS: 8

\begin{tabular}{|c|c|c|c|c|}
\hline & TOCUGG & LOGTDC & GML & $\mathrm{H} 2 \mathrm{O}$ \\
\hline $\begin{array}{l}\text { N OF CASES } \\
\text { MINIMUM } \\
\text { MAXIMUM } \\
\text { RANGE } \\
\text { MEAN } \\
\text { VARIANCE } \\
\text { STANDARD DEV } \\
\text { STD. ERROR } \\
\text { SKEWWNESS(G1) } \\
\text { KURTOSIS(G2) } \\
\text { SUM } \\
\text { C.V. } \\
\text { MEDIAN }\end{array}$ & $\begin{array}{r}800.000 \\
6718.310 \\
5918.310 \\
3593.400 \\
4118714.242 \\
2029.462 \\
717.523 \\
0.354 \\
-1.053 \\
28747.203 \\
0.565 \\
2961.095\end{array}$ & $\begin{array}{r}8 \\
2.903 \\
3.827 \\
0.924 \\
3.480 \\
0.088 \\
0.296 \\
0.105 \\
-0.727 \\
-0.105 \\
27.843 \\
0.085 \\
3.471\end{array}$ & $\begin{array}{r}1 \\
1.388 \\
1.388 \\
0.000 \\
1.388\end{array}$ & $\begin{array}{r}45.800 \\
45.800 \\
0.000 \\
45.800\end{array}$ \\
\hline
\end{tabular}

THE FOLLOWING RESULTS ARE FOR: SORWTGROS = III

TOTAL OBSERVATIONS: 6

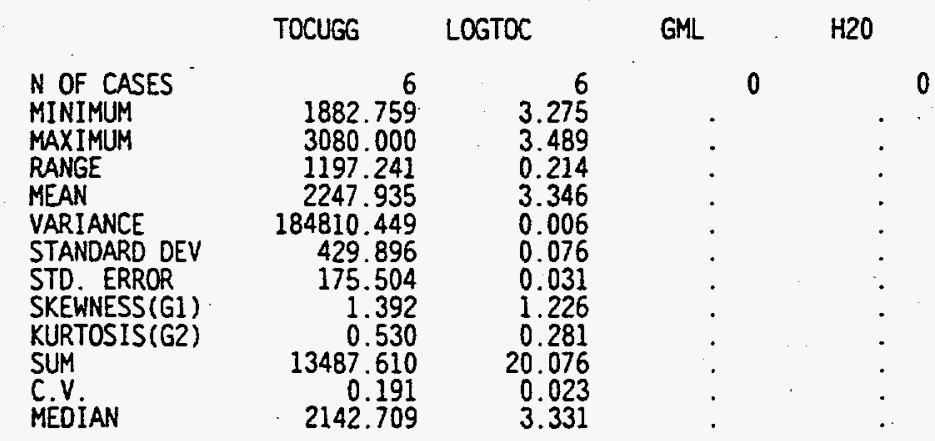

C. 1 
THE FOLLOWING RESULTS ARE FOR:

SORWTGROS = IV

TOTAL OBSERVATIONS: 7

LOGTOC

GML

H.O

$N$ OF CASES

MINIMUM

MAXIMUM

RANGE

MEAN

VARIANCE

STANDARD DEV

STD ERROR

SKEWNESS (G1)

KURTOSIS (G2)

SUM

C.V.

MEDIAN

7
2238.806
7820.268
5581.462
5336.777
780033.163
2186.329
826.355
-0.123
-1.461
37357.437
0.410

7

3.893

3.893
0.543

3.690

0.041

0.077

$-0.543$

$-0.964$

25.831

4717.557

0.055

3.674

THE FOLLOWING RESULTS ARE FOR:

SORWTGROS = IX

TOTAL OBSERVATIONS: $\quad 35$

TOCUGG LOGTOC GML $\quad \mathrm{H} 2 \mathrm{O}$

\section{N OF CASES}

MINIMUM

MAXIMUM

RANGE

MEAN

VARIANCE

STANDARD DEV

STD. ERROR

SKEWNESS (G1)

KURTOSIS (G2)

SUM

C V

MEOIAN

35
0.000
33640.624
33640.624
8078.484
$437084 \dot{E}+08$
6611.229
1117.502
2.344
6.211
282746.935
0.818
6387.097

34
3.094
4.527
1.432
3.824
0.083
0.288
0.049
0.062
0.684
130.031
0.075
3.810

19

1.280

1.685
0.405

1.422

0.010

0.100

0.023

0.646

0.588

27.013

0.071

34.860

65.860

31.000

48.864

53.267

7.298
1.770

0.832

1.134

830.690

0.149

48.260

THE FOLLOWING RESULTS ARE FOR:

SORWTGROS

\section{VI}

TOTAL OBSERVATIONS: 1

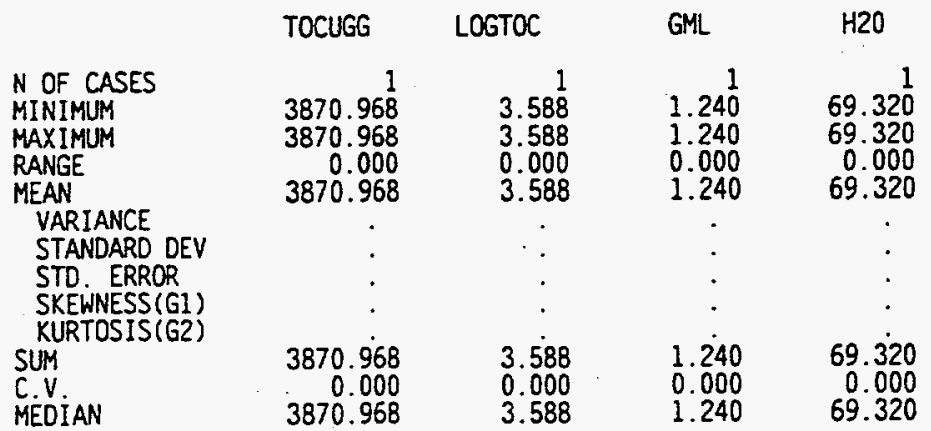


THE FOLLOWING RESULTS ARE FOR:

SORWTGROS = VII

TOTAL OBSERVATIONS: 4

\begin{tabular}{|c|c|c|c|c|}
\hline & TOCUGG & LOGTOC & GML & $\mathrm{H} 2 \mathrm{O}$ \\
\hline $\begin{array}{l}\text { N OF CASES } \\
\text { MINIMUM } \\
\text { MAXIMUM } \\
\text { RANGE } \\
\text { MEAN } \\
\text { VARIANCE } \\
\text { STANDARD DEV } \\
\text { STD. ERROR } \\
\text { SKEWNESS(G1) } \\
\text { KURTOSIS(G2) }\end{array}$ & $\begin{array}{r}4 \\
251.969 \\
99600.000 \\
99348.031 \\
34266.050 \\
.218544 E+10 \\
46748.733 \\
23374.367 \\
0.760 \\
-1.062\end{array}$ & $\begin{array}{r}4 \\
2.401 \\
4.998 \\
2.597 \\
3.704 \\
1.611 \\
1.269 \\
0.635 \\
-0.004 \\
-1.844\end{array}$ & $\begin{array}{c}1 \\
1.306 \\
1.306 \\
0.000 \\
1.306 \\
: \\
:\end{array}$ & $\begin{array}{r}1 \\
61.910 \\
61.910 \\
0.000 \\
61.910\end{array}$ \\
\hline $\begin{array}{l}\text { SUM } \\
\text { C.V. } \\
\text { MEDIAN }\end{array}$ & $\begin{array}{r}137064.199 \\
1.364 \\
18605.115\end{array}$ & $\begin{array}{r}14.815 \\
0.343 \\
3.707\end{array}$ & $\begin{array}{l}1.306 \\
0.000 \\
1.306\end{array}$ & $\begin{array}{r}61.910 \\
0.000 \\
61.910\end{array}$ \\
\hline
\end{tabular}

THE FOLLOWING RESULTS ARE FOR:

$$
\text { SORWTGROS = VIII }
$$

TOTAL OBSERVATIONS: 8

\begin{tabular}{lrrrr} 
& \multicolumn{1}{c}{ TOCUGG } & \multicolumn{1}{c}{ LOGTOC } & \multicolumn{1}{l}{ GML } & \multicolumn{1}{c}{ H20 } \\
N OF CASES & 6 & 6 & 3 & 4 \\
MINIMUM & 354.000 & 2.549 & 1.020 & 34.000 \\
MAXIMUM & 2000.000 & 3.301 & 1.200 & 95.100 \\
RANGE & 1646.000 & 0.752 & 0.180 & 61.100 \\
MEAN & 1005.667 & 2.943 & 1.110 & 71.425 \\
VARIANCE & 325824.667 & 0.065 & 0.008 & 699.329 \\
STANDARD DEV & 570.811 & 0.255 & 0.090 & 26.445 \\
STD. ERROR & 233.032 & 0.104 & 0.052 & 13.222 \\
SKEWNESS(G1) & 0.780 & -0.179 & -0.000 & -0.783 \\
KURTOSIS(G2) & -0.344 & -0.677 & -1.500 & -0.916 \\
SUM & 6034.000 & 17.657 & 3.330 & 285.700 \\
C.V. & 0.568 & 0.087 & 0.081 & 0.370 \\
MEDIAN & 890.000 & 2.941 & 1.110 & 78.300
\end{tabular}

THE FOLLOWING RESULTS ARE FOR:

$$
\text { SORWTGROS }=\text { XI }
$$

\begin{tabular}{|c|c|c|c|c|}
\hline & TOCUEG & LOGTOC & GML & $\mathrm{H} 2 \mathrm{O}$ \\
\hline $\begin{array}{l}\text { N OF CASES } \\
\text { MINIMUUM } \\
\text { MAXIMUM } \\
\text { RANGE } \\
\text { MEAN } \\
\text { VARIANCE } \\
\text { STANDARD DEV } \\
\text { STD. ERROR } \\
\text { SKEWNESS(G1) } \\
\text { KURTOSIS(G2) } \\
\text { SUM } \\
\text { C.V. } \\
\text { MEDIAN }\end{array}$ & $\begin{array}{r}2 \\
526.667 \\
2213.115 \\
1686.448 \\
1369.891 \\
1422053.576 \\
1192.499 \\
843.224 \\
0.000 \\
-2.000 \\
2739.781 \\
0.871 \\
1369.891\end{array}$ & $\begin{array}{c}2 \\
2.722 \\
3.345 \\
0.623 \\
3.033 \\
0.194 \\
0.441 \\
0.312 \\
0.000 \\
-2.000 \\
6.067 \\
0.145 \\
3.033\end{array}$ & $\begin{array}{l}0 \\
: \\
: \\
: \\
: \\
:\end{array}$ & : \\
\hline
\end{tabular}

TOTAL OBSERVATIONS: 2 
THE FOLLOWING RESULTS ARE FOR:

SORWTGROS $=$ XII

TOTAL OBSERVATIONS: 1

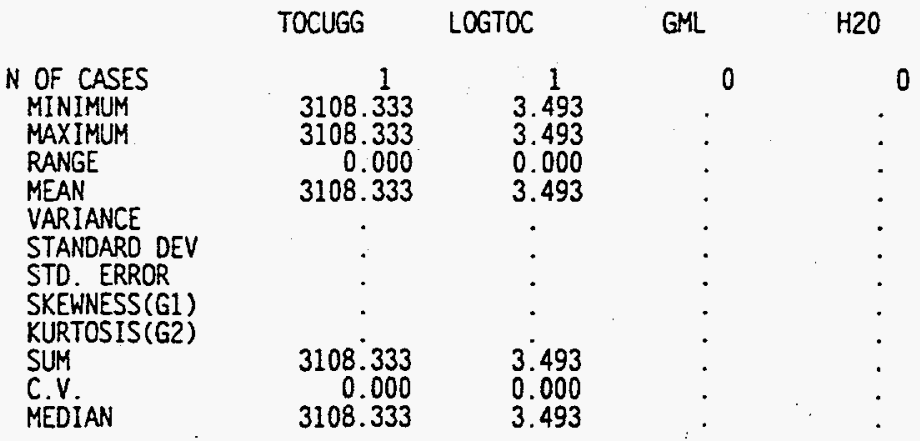

THE FOLLOWING RESULTS ARE FOR:

SORWTGROS $=$ XIV

TOTAL OBSERVATIONS: 1

$\begin{array}{cccc}\text { TOCUGG } & \text { LOGTOC } & \text { GML } & \text { H20 } \\ 1900.000 & 3.279 & & 0 \\ 1900.000 & 3.279 & : & 0 \\ 0.000 & 0.000 & : & : \\ 1900.000 & 3.279 & : & : \\ : & : & : & : \\ : & : & : & \vdots \\ 1900.000 & 3.279 & : & : \\ 0.000 & 0.000 & : & : \\ 1900.000 & 3.279 & : & :\end{array}$

THE FOLLOWING RESULTS ARE FOR:

SORWTGROS $=$ XIX

TOTAL OBSERVATIONS: 1

$\begin{array}{cccc}\text { TOCUGG } & \text { LOGTOC } & \text { GML } & \text { H2O } \\ 1 & 1 & & 0 \\ 500.000 & 2.699 & : & 0 \\ 500.000 & 2.699 & : & : \\ 0.000 & 0.000 & : & : \\ 500.000 & 2.699 & : & : \\ : & : & : & : \\ : & : & : & : \\ 500.000 & 2.699 & : & : \\ 0.000 & 0.000 & : & : \\ 500.000 & 2.699 & : & :\end{array}$


THE FOLLOWING RESULTS ARE FOR:

SORWTGROS $=X X I$

TOTAL OBSERVATIONS: 5

\begin{tabular}{rccc}
\multicolumn{1}{c}{ TOCUGG } & \multicolumn{1}{l}{ LOGTOC } & GML & H2O \\
5 & 5 & 0 & 0 \\
1418.440 & 3.152 & $:$ & $:$ \\
3700.000 & 3.568 & $:$ & $:$ \\
2281.560 & 0.416 & $:$ & $:$ \\
2645.745 & 3.388 & $:$ & $:$ \\
1164456.562 & 0.040 & $:$ & $:$ \\
1079.100 & 0.200 & $:$ & $:$ \\
482.588 & 0.090 & $:$ & $:$ \\
-0.316 & -0.377 & $:$ & $:$ \\
-1.767 & -1.778 & $:$ & $:$ \\
13228.725 & 16.941 & $:$ & 0.059 \\
0.408 & 0.499 & $:$ &
\end{tabular}

THE FOLLOWING RESULTS ARE FOR:

SORWTGROS

= XXII

TOTAL OBSERVATIONS: 7

\begin{tabular}{rccc}
\multicolumn{1}{l}{ TOCUGG } & LOGTOC & GML & H2O \\
7 & 7 & $:$ & 0 \\
174.472 & 2.242 & $:$ & $:$ \\
32200.000 & 4.508 & $:$ & $:$ \\
32025.528 & 2.266 & $:$ & $:$ \\
6196.312 & 3.272 & $:$ & $:$ \\
$134986 \mathrm{E}+09$ & 0.498 & $:$ & $:$ \\
11618.347 & 0.706 & $:$ & $:$ \\
4391.323 & 0.267 & $:$ & $:$ \\
1.938 & 0.452 & $:$ & $:$ \\
1.919 & -0.233 & $:$ & $:$ \\
43374.182 & 22.906 & $:$ & $:$ \\
1.875 & 0.216 & $:$ &
\end{tabular}

THE FOLLOWING RESULTS ARE FOR:

SORWTGROS = XXIII

TOTAL OBSERVATIONS: 7

\begin{tabular}{lrc} 
& \multicolumn{1}{l}{ TOCUGG } & \multicolumn{1}{l}{ LOGTOC } \\
N OF CASES & \multicolumn{1}{c}{7} \\
MINIMUM & 1900.000 & 7 \\
MAXIMUM & 7018.868 & 3.279 \\
RANGE & 5118.868 & 0.846 \\
MEAN & 5810.702 & 3.733 \\
VARIANCE & 3363846.910 & 0.042 \\
STANDARD DEV & 1834.079 & 0.205 \\
STD. ERROR & 693.217 & 0.077 \\
SKEWNESS(G1) & -1.590 & -1.858 \\
KURTOSIS(G2) & 1.124 & 1.748 \\
SUM & 40674.915 & 26.128 \\
C.V. & 0.316 & 0.055 \\
MEDIAN & 6639.640 & 3.822
\end{tabular}

GML

$\mathrm{H} 2 \mathrm{O}$ 
THE FOLLOWING RESULTS ARE FOR:

SORWTGROS $=X X I V$

TOTAL OBSERVATIONS: 2

$\begin{array}{rccc}\text { TOCUGG } & \text { LOGTOC } & \text { GML } & \text { H2O } \\ 2 & 2 & - & 0 \\ 3958.333 & 3.598 & : & 0 \\ 4087.591 & 3.611 & : & : \\ 129.258 & 0.014 & : & : \\ 4022.962 & 3.604 & : & : \\ 8353.803 & 0.000 & : & : \\ 91.399 & 0.010 & : & : \\ 64.629 & 0.007 & : & : \\ 0.000 & 0.000 & : & : \\ -2.000 & -2.000 & : & : \\ 8045.925 & 7.209 & : & : \\ 0.023 & 0.003 & : & : \\ 4022.962 & 3.604 & : & :\end{array}$

THE FOLLOWING RESULTS ARE FOR: SORWTGROS $=$ XXVI

TOTAL OBSERVATIONS: 3

\begin{tabular}{rccc}
\multicolumn{1}{l}{ TOCUGG } & LOGTOC & GML & H2O \\
3 & 3 & 0 & 0 \\
2680.412 & 3.428 & $:$ & $:$ \\
2768.000 & 3.442 & $:$ & $:$ \\
87.588 & 0.014 & $:$ & $:$ \\
2722.804 & 3.435 & $:$ & $:$ \\
1923.796 & 0.000 & $:$ & $:$ \\
43.861 & 0.007 & $:$ & $:$ \\
25.323 & 0.004 & $:$ & $:$ \\
0.117 & 0.107 & $:$ & $:$ \\
-1.500 & -1.500 & $:$ & $:$ \\
8168.412 & 10.305 & $:$ & $:$ \\
0.016 & 0.002 & $:$ & $:$
\end{tabular}

THE FOLLOWING RESULTS ARE FOR:

$\begin{array}{lrr}\text { N OF CASES } & 3 & 3 \\ \text { MINIMUM } & 2680.412 & 3.428 \\ \text { MAXIMUM } & 2768.000 & 3.442 \\ \text { RANGE } & 87.588 & 0.014 \\ \text { MEAN } & 2722.804 & 3.435 \\ \text { VARIANCE } & 1923.796 & 0.000 \\ \text { STANDARO DEV } & 43.861 & 0.007 \\ \text { STD. ERROR } & 25.323 & 0.004 \\ \text { SKEWNESS(G1) } & 0.117 & 0.107 \\ \text { KURTOSIS(G2) } & -1.500 & -1.500 \\ \text { SUM } & 8168.412 & 10.305 \\ \text { C.V. } & 0.016 & 0.002 \\ \text { MEDIAN } & 2720.000 & 3.435\end{array}$
SORWTGROS $=$ XXVII

TOTAL OBSERVATIONS: 4

TOCUGG LOGTOC GML H2O

\begin{tabular}{lrrcc} 
N OF CASES & \multicolumn{1}{c}{4} & 4 & 0 & 0 \\
MINIMUM & 1564.516 & 3.194 & $:$ & $:$ \\
MAXIMUM & 2042.373 & 3.310 & $:$ & $:$ \\
RANGE & 477.857 & 0.116 & $:$ & $:$ \\
MEAN & 1726.138 & 3.235 & $:$ & $:$ \\
VARIANCE & 47399.328 & 0.003 & $:$ & $:$ \\
STANDARD .DEV & 217.714 & 0.052 & $:$ & $:$ \\
STD. ERROR & 108.857 & 0.026 & $:$ & $:$ \\
SKEWNESS(G1) & 0.952 & 0.909 & $:$ & $:$ \\
KURTOSIS(G2) & -0.842 & -0.880 & $:$ & $:$ \\
SUM & 6904.552 & 12.939 & $:$ & \\
C.V. & 0.126 & 0.016 & $:$ &
\end{tabular}

C. 6 
THE FOLLOWING RESULTS ARE FOR:

SORWTGROS $=$ XXVIII

TOTAL OBSERVATIONS: 7

\begin{tabular}{|c|c|c|c|c|}
\hline & TOCUGG & LOGTOC & GML & $\mathrm{H} 2 \mathrm{O}$ \\
\hline $\begin{array}{l}\text { N OF CASES } \\
\text { MINIMUM } \\
\text { MAXIMUM } \\
\text { RANGE } \\
\text { MEAN } \\
\text { VARIANCE } \\
\text { STANDARD DEV } \\
\text { STD. ERROR } \\
\text { SKEWNESS(GI) } \\
\text { KURTOSIS(G2) } \\
\text { SUM } \\
\text { C.V. } \\
\text { MEDIAN }\end{array}$ & $\begin{array}{r}7 \\
3300.000 \\
28300.000 \\
25000.000 \\
14577.003 \\
967001 \mathrm{E}+08 \\
9833.623 \\
3716.760 \\
0.588 \\
-1.198 \\
102039.023 \\
0.675 \\
10351.967\end{array}$ & $\begin{array}{r}7 \\
3.519 \\
4.452 \\
0.933 \\
4.069 \\
0.106 \\
0.325 \\
0.123 \\
-0.313 \\
-0.669 \\
28.482 \\
0.080 \\
4.015\end{array}$ & $\begin{array}{l}0 \\
: \\
: \\
: \\
: \\
: \\
: \\
: \\
.\end{array}$ & $\begin{array}{l}. \\
: \\
: \\
: \\
: \\
: \\
: \\
:\end{array}$ \\
\hline
\end{tabular}

THE FOLLOWING RESULTS ARE FOR:

SORWTGROS $=$ XXXA

TOTAL OBSERVATIONS: $\quad 2$

TOCUGG LOGTOC GML H2O

$\begin{array}{lrrrr}\text { N OF CASES } & & 2 & 2 & \\ \text { MINIMUM } & 95.588 & 1.980 & 1.350 & 51.500 \\ \text { MAXIMUM } & 4177.778 & 3.621 & 1.360 & 52.400 \\ \text { RANGE } & 4082.190 & 1.641 & 0.010 & 0.900 \\ \text { MEAN } & 2136.683 & 2.801 & 1.355 & 51.950 \\ \text { VARIANCE } & 8332135.730 & 1.346 & 0.000 & 0.405 \\ \text { STANDARD DEV } & 2886.544 & 1.160 & 0.007 & 0.636 \\ \text { STD. ERROR } & 2041.095 & 0.820 & 0.005 & 0.450 \\ \text { SKEWNESS(G1) } & 0.000 & 0.000 & 0.000 & 0.000 \\ \text { KURTOSIS(G2) } & -2.000 & -2.000 & -2.000 & -2.000 \\ \text { SUM } & 4273.366 & 5.601 & 2.710 & 103.900 \\ \text { C.V.V } & 1.351 & 0.414 & 0.005 & 0.012 \\ \text { MEDIAN } & 2136.683 & 2.801 & 1.355 & 51.950\end{array}$

THE FOLLOWING RESULTS ARE FOR:

SORWTGROS $=X X X B$

TOTAL OBSERVATIONS: 1

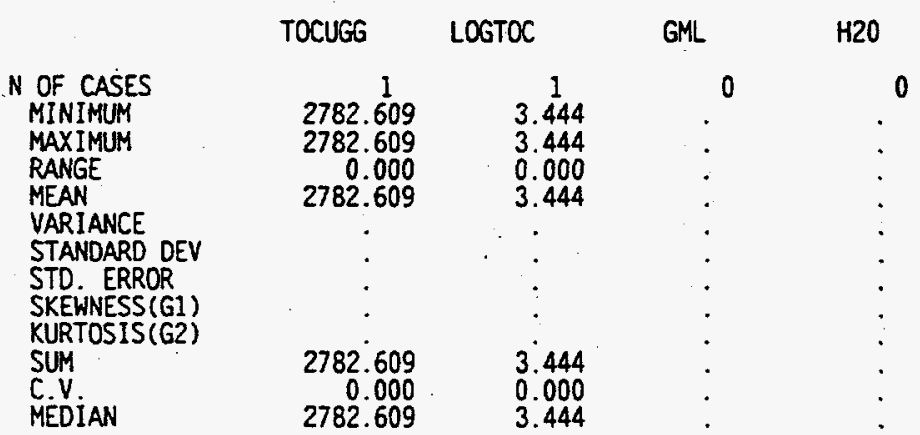

C. 7 
THE FOLLOWING RESULTS ARE FOR:

SORWTGROS $=X X X C$

TOTAL OBSERVATIONS: 1

\begin{tabular}{|c|c|c|c|}
\hline TOCUGG & LOGTOC & GML & $\mathrm{H} 2 \mathrm{O}$ \\
\hline $\begin{array}{r}1 \\
8728.814 \\
8728.814 \\
0.000 \\
8728.814\end{array}$ & $\begin{array}{c}1 \\
3.941 \\
3.941 \\
0.000 \\
3.941\end{array}$ & . & . \\
\hline • & $\cdot$ & - & $\cdot$ \\
\hline$\dot{.}$ & $\dot{0}$ & : & $\dot{.}$ \\
\hline$\cdot$ & . & . & . \\
\hline $\begin{array}{r}8728.814 \\
0.000 \\
8728.814\end{array}$ & $\begin{array}{l}3.941 \\
0.000 \\
3.941\end{array}$ & : & : \\
\hline
\end{tabular}

THE FOLLOWING RESULTS ARE FOR: SORWTGROS $=$ XXXD

TOTAL OBSERVATIONS: 1

TOCUGG LOGTOC GML

$\begin{array}{lcc}\text { N OF CASES } & 1 & 1 \\ \text { MINIMUM } & 2333.333 & 3.368 \\ \text { MAXIMUM } & 2333.333 & 3.368 \\ \text { RANGE } & 0.000 & 0.000 \\ \text { MEAN } & 2333.333 & 3.368 \\ \text { VARIANCE } & \cdot & \cdot \\ \text { STANDARD DEV } & \cdot & \cdot \\ \text { STD. ERROR } & \cdot & \cdot \\ \text { SKEWNESS(G1) } & : & \cdot \\ \text { KURTOSIS(G2) } & 2333.333 & 3.368 \\ \text { SUM } & 0.000 & 0.000 \\ \text { C.V. } & 2333.333 & 3.368\end{array}$

THE FOLLOWING RESULTS ARE FOR:

SORWTGROS $=$ XXXE

TOTAL OBSERVATIONS: 1

$\begin{array}{cccc}\text { TOCUGS } & \text { LOGTOC } & \text { GML } & \text { H2O } \\ 1 & 1 & & 0 \\ 903.509 & 2.956 & : & 0 \\ 903.509 & 2.956 & : & : \\ 0.000 & 0.000 & : & : \\ 903.509 & 2.956 & : & : \\ : & : & : & : \\ : & : & : & : \\ 903.509 & 2.956 & : & : \\ 0.000 & 0.000 & : & : \\ 903.509 & 2.956 & : & :\end{array}$


THE FOLLOWING RESULTS ARE FOR: SORWTGROS $=X X X F$

TOTAL OBSERVATIONS: 2

TOCUGG LOGTOC GML H2O

N OF CASES
MINIMUM
MAXIMUM
RANGE
MEAN
VARIANCE
STANDARD DEV
STO. ERROR
SKEWNESS(G1)
KURTOSIS(G2)
SUM
C.V.
MEDIAN

492. 11000

492.000

0.000

$\frac{1}{692}$

(1)

492.000

2.692

1.100

1.100

$0.000 \quad 0.000$
2.692
1.100

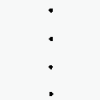

492.000

0.000

492.000

2.692

0.000

2.692

1.100

0.000

1.100

THE FOLLOWING RESULTS ARE FOR:

SORWTGROS $=X X X G$

TOTAL OBSERVATIONS: 1

$\begin{array}{cccc}\text { TOCUGG } & \text { LOGTOC } & \text { GML } & \text { H2O } \\ 1 & 1 & 0 & 0 \\ 184.162 & 2.265 & : & : \\ 184.162 & 2.265 & : & \vdots \\ 0.000 & 0.000 & : & : \\ 184.162 & 2.265 & : & : \\ : & : & : & : \\ . & : & : & : \\ 184.162 & 2.265 & : & : \\ 0.000 & 0.000 & : & : \\ 184.162 & 2.265 & : & \end{array}$




\section{C.2 - Sludge Phase}

TUE 9/20/94 2:56:51 PM D:ITOCITOCLOCK.SYS

THE FOLLOWING RESULTS ARE FOR:

SORWTGROS = II

TOTAL OBSERVATIONS: 1

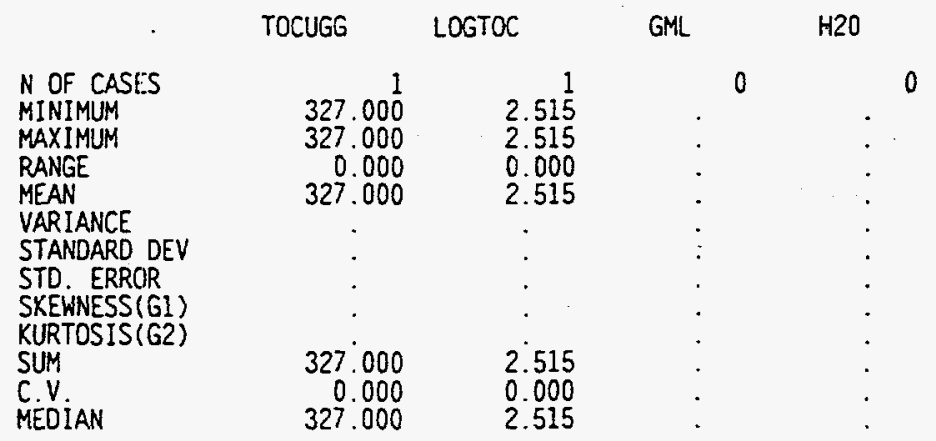

THE FOLLOWING RESULTS ARE FOR:

SORWTGROS = IV

TOTAL OBSERVATIONS: 5

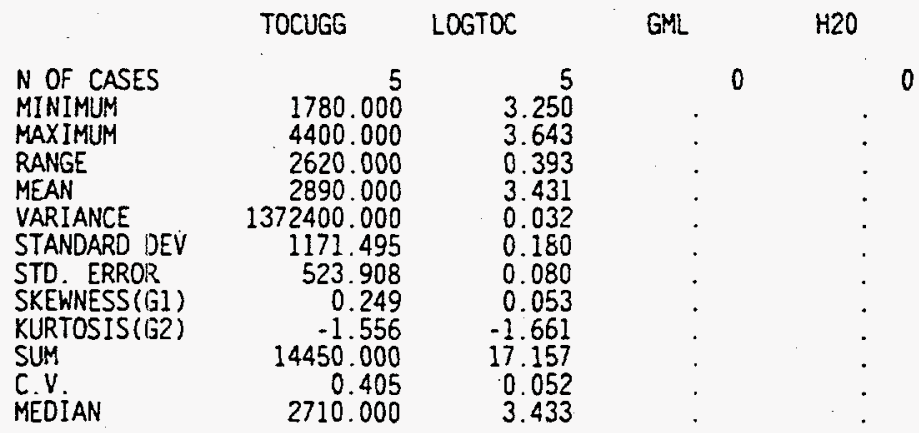

THE FOLLOWING RESULTS ARE FOR:
SORWTGROS

TOTAL OBSERVATIONS: 5

\begin{tabular}{|c|c|c|c|c|}
\hline & TOCUGG & LOGTOC & GML & $\mathrm{H} 2 \mathrm{O}$ \\
\hline $\begin{array}{l}\text { N OF CASES } \\
\text { MINIMUUM } \\
\text { MAXIMUM } \\
\text { RANGE } \\
\text { MEAN } \\
\text { VARIANCE } \\
\text { STANDARD OEV } \\
\text { STD. ERROR } \\
\text { SKEWNESS(G1) } \\
\text { KURTOSIS (G2) } \\
\text { SUM } \\
C . V \\
\text { MEDIAN }\end{array}$ & $\begin{array}{r}7200.000 \\
8040.000 \\
840.000 \\
7703.739 \\
108091.645 \\
328.773 \\
147.032 \\
-0.609 \\
-0.850 \\
38518.696 \\
0.043 \\
7730.000\end{array}$ & $\begin{array}{r}5 \\
3.857 \\
3.905 \\
0.048 \\
3.886 \\
0.000 \\
0.019 \\
0.008 \\
-0.654 \\
-0.805 \\
19.432 \\
0.005 \\
3.888\end{array}$ & $\begin{array}{r}4 \\
1.340 \\
1.660 \\
0.320 \\
1.468 \\
0.023 \\
0.153 \\
0.076 \\
0.388 \\
-1.496 \\
5.870 \\
0.104 \\
1.435\end{array}$ & $\begin{array}{r}4 \\
29.400 \\
40.920 \\
11.520 \\
37.680 \\
30.592 \\
5.531 \\
2.766 \\
-1.141 \\
-0.677 \\
150.720 \\
0.147 \\
40.200\end{array}$ \\
\hline
\end{tabular}


THE FOLLOWING RESULTS ARE FOR:

SORWTGROS

$=V$

TOTAL OBSERVATIONS: 27

\begin{tabular}{|c|c|c|c|c|}
\hline & TOCUGG & LOGTOC & GML & $\mathrm{H} 2 \mathrm{O}$ \\
\hline $\begin{array}{l}\text { N OF CASES } \\
\text { MINIMUM } \\
\text { MAXIMUM } \\
\text { RANGE } \\
\text { MEAN } \\
\text { VARIANCE } \\
\text { STANDARD DEV } \\
\text { STD. ERROR } \\
\text { SKEWNESS(G1) } \\
\text { KURTOSIS(G2) } \\
\text { SUM } \\
\text { C.V } \\
\text { MEDIAN }\end{array}$ & $\begin{array}{r}17 \\
30.000 \\
33200.000 \\
33170.000 \\
7759.762 \\
139631 \mathrm{E}+09 \\
11816.568 \\
2865.939 \\
1.634 \\
0.782 \\
131915.948 \\
1.523 \\
2300.000\end{array}$ & $\begin{array}{r}13 \\
3.005 \\
4.521 \\
1.516 \\
3.685 \\
0.259 \\
0.508 \\
0.141 \\
0.770 \\
-0.748 \\
47.910 \\
0.138 \\
3.562\end{array}$ & $\begin{array}{r}3 \\
1.140 \\
1.250 \\
0.110 \\
1.213 \\
0.004 \\
0.064 \\
0.037 \\
-0.707 \\
-1.500 \\
3.640 \\
0.052 \\
1.250\end{array}$ & $\begin{array}{r}40.000 \\
76.000 \\
36.000 \\
52.000 \\
432.000 \\
20.785 \\
12.000 \\
0.707 \\
-1.500 \\
156.000 \\
0.400 \\
40.000\end{array}$ \\
\hline
\end{tabular}

THE FOLLOWING RESULTS ARE FOR:

SORWTGROS $=V I$

TOTAL OBSERVATIONS: 13

TOCUGG LOGTOC GML H2O

N OF CASES
MINIMUM
MAXIMUM
RANGE
MEAN
VARIANCE
STANDARD DEV
STD. ERROR
SKEWNESS(G1)
KURTOSIS(G2)
SUM
C.
MEDIAN

11

1090.000

1290.000

1669.091

1669.091
327629.091

572.389

172.582

0.198

$-1.834$

18360.000

0.343

1300.000

$$
\begin{array}{r}
11 \\
3.037 \\
3.377 \\
0.339 \\
3.199 \\
0.023 \\
0.150 \\
0.045 \\
0.132 \\
-1.840 \\
35.187 \\
0.047 \\
3.114
\end{array}
$$

THE FOLLOWING RESULTS ARE FOR:

$$
\text { SORWTGROS }=\text { VII }
$$

TOTAL OBSERVATIONS: 1

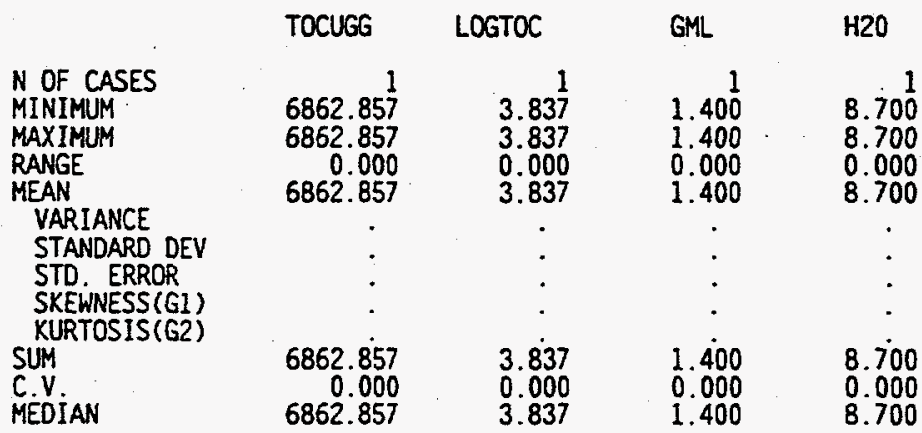


THE FOLLOWING RESULTS ARE FOR:

SORWTGROS

- VIII

TOTAL OBSERVATIONS:

49

\begin{tabular}{|c|c|c|c|c|}
\hline & TOCUGG & LOGTOC & GML & $\mathrm{H} 2 \mathrm{O}$ \\
\hline $\begin{array}{l}\text { N OF CASES } \\
\text { MINIMUM } \\
\text { MAXIMUM } \\
\text { RANGE } \\
\text { MEAN } \\
\text { VARIANCE } \\
\text { STANDARD DEV } \\
\text { STO. ERROR } \\
\text { SKEWNESS(GI) } \\
\text { KURTOSIS(G2) } \\
\text { SUM } \\
\text { C.V. } \\
\text { MEOIAN }\end{array}$ & $\begin{array}{r}38 \\
265.000 \\
8200.000 \\
7935.000 \\
2293.158 \\
2515155.974 \\
1585.924 \\
257.271 \\
1.231 \\
3.158 \\
87140.000 \\
0.692 \\
2450.000\end{array}$ & $\begin{array}{r}38 \\
2.423 \\
.4 .914 \\
1.491 \\
3.228 \\
0.152 \\
0.389 \\
0.063 \\
-0.792 \\
-0.364 \\
122.669 \\
0.121 \\
3.388\end{array}$ & $\begin{array}{r}10 \\
1.190 \\
1.710 \\
0.520 \\
1.513 \\
0.020 \\
0.143 \\
0.045 \\
-0.785 \\
1.006 \\
15.130 \\
0.095 \\
1.510\end{array}$ & $\begin{array}{r}31 \\
5.760 \\
95.600 \\
89.840 \\
48.318 \\
285.071 \\
16.884 \\
3.032 \\
-0.123 \\
1.690 \\
1497.860 \\
0.349 \\
51.400\end{array}$ \\
\hline
\end{tabular}

THE FOLLOWING RESULTS ARE FOR:

SORWTGROS $=X$

TOTAL OBSERVATIONS: 1

TOCUEG LOGTOC GML H2O

$\begin{array}{llccc}\text { N OF CASES } & 0 & 0 & 0 & 0 \\ \text { MINIMUM } & : & : & : & : \\ \text { MAXIMUM } & : & : & : & : \\ \text { RANGE } & : & : & : & : \\ \text { MEAN } & : & : & : & : \\ \text { VARIANCE } & : & : & : & : \\ \text { STANDARD DEV } & : & : & : & : \\ \text { STD. ERROR } & : & : & : & : \\ \text { SKEWNESS(G1) } & : & : & : & : \\ \text { KURTOSIS(G2) } & \text { SUM } & & & \end{array}$

THE FOLLOWING RESULTS ARE FOR:

SORWTGROS $=$ XI

TOTAL OBSERVATIONS: 32

\begin{tabular}{lrrrr} 
& \multicolumn{1}{c}{ TOCUGG } & \multicolumn{1}{l}{ LOGTOC } & \multicolumn{1}{l}{ GML } & \multicolumn{1}{c}{ H20 } \\
N OF CASES & 14 & 14 & 2 & 14 \\
MINIMUM & 500.000 & 2.699 & 1.440 & 34.600 \\
MAXIMUM & 1090.000 & 3.037 & 1.440 & 64.500 \\
RANGE & 590.000 & 0.338 & 0.000 & 29.900 \\
MEAN & 717.929 & 2.837 & 1.440 & 49.464 \\
VARIANCE & 51523.764 & 0.017 & 0.000 & 76.712 \\
STANDARD DEV & 226.988 & 0.130 & 0.000 & 8.759 \\
STD. ERROR & 60.665 & 0.035 & 0.000 & 2.341 \\
SKEWNESS(G1) & 0.678 & 0.492 & 0.000 & 0.111 \\
KURTOSIS(G2) & -1.111 & -1.327 & 0.000 & -0.669 \\
SUM & 10051.000 & 39.722 & 2.880 & 692.500 \\
C.V. & 0.316 & 0.046 & 0.000 & 0.177 \\
MEDIAN & 625.000 & 2.793 & 1.440 & 50.450
\end{tabular}

C. 12 
THE FOLLOWING RESULTS ARE FOR:
SORWTGROS

TOTAL OBSERVATIONS: 3

\begin{tabular}{lrrrr} 
& \multicolumn{1}{c}{ TOCUGG } & \multicolumn{1}{l}{ LOGTOC } & \multicolumn{1}{l}{ GML } & \multicolumn{1}{c}{ H2O } \\
N OF CASES & & 3 & 2 & 2 \\
MINIMUM & 1220.000 & 3.086 & 1.380 & 57.470 \\
MAXIMUM & 10150.000 & 4.006 & 1.380 & 57.470 \\
RANGE & 8930.000 & 0.920 & 0.000 & 0.000 \\
MEAN & 6766.667 & 3.681 & 1.380 & 57.470 \\
VARIANCE & $.234462 E+08$ & 0.266 & 0.000 & 0.000 \\
STANDARD DEV & 4842.131 & 0.516 & 0.000 & 0.000 \\
STD ERROR & 2795.606 & 0.298 & 0.000 & 0.000 \\
SKEWNESS(G1) & -0.657 & -0.698 & 0.000 & 0.000 \\
KURTOSIS(G2) & -1.500 & -1.500 & 0.000 & 0.000 \\
SUM & 20300.000 & 11.044 & 2.760 & 114.940 \\
C.V & 0.716 & 0.140 & 0.000 & 0.000 \\
MEDIAN & 8930.000 & 3.951 & 1.380 & 57.470
\end{tabular}

THE FOLLOWING RESULTS ARE FOR:

SORWTGROS $=$ XIII

TOTAL OBSERVATIONS: 1

\begin{tabular}{|c|c|c|c|}
\hline TOCUGG & LOGTOC & GML. & $\mathrm{H} 2 \mathrm{O}$ \\
\hline $\begin{array}{r}1 \\
2070.690 \\
2070.690 \\
0.000 \\
2070.690\end{array}$ & $\begin{array}{c}1 \\
3.316 \\
3.316 \\
0.000 \\
3.316\end{array}$ & ${ }^{0}$ & : \\
\hline • & $\cdot$ & - & - \\
\hline$\cdot$ & - & - & - \\
\hline . & . & . & 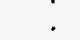 \\
\hline $\begin{array}{r}2070.690 \\
0.000 \\
2070.690\end{array}$ & $\begin{array}{l}3.316 \\
0.000 \\
3.316\end{array}$ & i. & . \\
\hline
\end{tabular}

THE FOLLOWING RESULTS ARE FOR:

SORLTGROS $=$ XIV

TOTAL OBSERVATIONS: 8

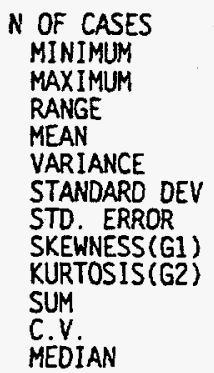

\begin{tabular}{rccc}
\multicolumn{1}{l}{ TOCUGG } & LOGTOC & GML & H2O \\
2000.000 & 3.301 & & 0 \\
4120.000 & 3.615 & $:$ & 0 \\
2120.000 & 0.314 & $\vdots$ & $:$ \\
3118.750 & 3.480 & $:$ & $:$ \\
630926.786 & 0.015 & $:$ & $:$ \\
794.309 & 0.121 & $:$ & $:$ \\
280.831 & 0.043 & $:$ & $:$ \\
-0.374 & -0.622 & $:$ & $:$ \\
-1.144 & -1.036 & $:$ & $:$ \\
24950.000 & 27.841 & $:$ & $:$ \\
0.255 & 0.035 & $:$ & $:$ \\
3150.000 & 3.498 & $:$ & $:$
\end{tabular}

C. 13 
THE FOLLOWING RESULTS ARE FOR:

$$
\text { SORKTGROS }=X V
$$

TOTAL OBSERVATIONS: 48

$\begin{array}{rccc}\text { TOCUGG } & \text { LOGTOC } & \text { GML } & \text { H2O } \\ 22 & 22 & 0 & 0 \\ 298.000 & 2.474 & . & : \\ 1620.000 & 3.210 & . & : \\ 1322.000 & 0.735 & : & : \\ 633.500 & 2.729 & : & : \\ 183095.595 & 0.058 & : & : \\ 427.897 & 0.241 & : & : \\ 91.228 & .0 .051 & : & : \\ 1.402 & 0.918 & : & : \\ 0.473 & -0.459 & : & : \\ 13937.000 & 60.036 & : & : \\ 0.675 & 0.088 & : & \end{array}$

THE FOLLOWING RESULTS ARE FOR:

$$
\text { SORWTGROS }=\text { XVII }
$$

TOTAL OBSERVATIONS: 52

$$
\text { TOCUGG LOGTOC GML } \mathrm{H2O}
$$

$\begin{array}{lrrrr}\text { N OF CASES } & 32 & 32 & 40 & 44 \\ \text { MINIMUM } & 352.000 & 2.547 & 1.000 & 3.080 \\ \text { MAXIMUM } & 6750.000 & 3.829 & 1.930 & 47.700 \\ \text { RANGE } & 6398.000 & 1.283 & 0.930 & 44.620 \\ \text { MEAN } & 1136.031 & 2.921 & 1.450 & 35.609 \\ \text { VARIANCE } & 2122882.547 & 0.077 & 0.063 & 161.565 \\ \text { STANDARD DEV } & 1457.012 & 0.278 & 0.250 & 12.711 \\ \text { STD. ERROR } & 257.566 & 0.049 & 0.040 & 1.916 \\ \text { SKEWINESS(G1) } & 3.412 & 1.998 & 0.060 & -1.729 \\ \text { KURTOSIS(G2) } & 10.159 & 4.554 & -0.660 & 1.593 \\ \text { SUM } & 36353.000 & 93.487 & 57.980 & 1566.800 \\ \text { C.V. } & 1.283 & 0.095 & 0.173 & 0.357 \\ \text { MEDIAN } & 737.000 & 2.867 & 1.460 & 39.150\end{array}$

THE FOLLOWING RESULTS ARE FOR:

\begin{tabular}{|c|c|c|c|}
\hline TOCUGG & LOGTOC & GML & $\mathrm{H} 2 \mathrm{O}$ \\
\hline $\begin{array}{r}4 \\
800.000 \\
4620.000 \\
3820.000 \\
2987.500 \\
803558.333 \\
1674.383 \\
837.191 \\
-0.443 \\
-1.263 \\
11950.000 \\
0.560 \\
3265.000\end{array}$ & $\begin{array}{c}4 \\
2.903 \\
3.665 \\
0.762 \\
3.395 \\
0.118 \\
0.343 \\
0.172 \\
-0.870 \\
-0.916 \\
13.579 \\
0.101 \\
3.506\end{array}$ & $\begin{array}{l}0 \\
: \\
: \\
: \\
: \\
: \\
: \\
\cdot \\
:\end{array}$ & $\begin{array}{l}0 \\
: \\
: \\
\therefore \\
\therefore \\
\therefore\end{array}$ \\
\hline
\end{tabular}

$$
\text { SORWTGROS }=\text { XXIII }
$$

TOTAL OBSERVATIONS: 4 
TOTAL OBSERVATIONS:

3

TOCUGG LOGTOC GML

$N$ OF CASES

MINIMUM

MAXIMUM

RANGE

MEAN

VARIANCE

STANDARD DEV

STD. ERROR

SKEWNESS(G1)

KURTOSIS(G2)

SUM

C

MEDIAN

3
169.000
700.000
531.000
489.667
79620.333
282.171
162.911
-0.609
-1.500
1469.000
0.576
600.000

3
2.228
2.845
0.617
2.617
0.115
0.339
0.196
-0.676
-1.500
7.851
0.129
2.778

1.450

1.450

0.000

1.450

0.000

0.000

0.000

0.000

0.000

2.900

0.000

1.450

$$
\begin{array}{r}
51.900 \\
51.900 \\
0.000 \\
51.900 \\
0.000 \\
0.000 \\
0.000 \\
0.000 \\
0.000 \\
103.800 \\
0.000 \\
51.900
\end{array}
$$

\begin{tabular}{|c|c|c|c|c|}
\hline & TOCUGG & LOGTOC & GML & $\mathrm{H} 2 \mathrm{O}$ \\
\hline $\begin{array}{l}\text { N OF CASES } \\
\text { MINIMUM } \\
\text { MAXIMUM } \\
\text { RANGE } \\
\text { MEAN } \\
\text { VARIANCE } \\
\text { STANDARD DEV } \\
\text { STD. ERROR } \\
\text { SKEWNESS(GI) } \\
\text { KURTOSIS(G2) } \\
\text { SUM } \\
\text { C.V } \\
\text { MEDIAN }\end{array}$ & $\begin{array}{r}7 \\
780.000 \\
2480.000 \\
1700.000 \\
1552.143 \\
502565.476 \\
708.919 \\
267.946 \\
-0.008 \\
-1.664 \\
10865.000 \\
0.457 \\
1700.000\end{array}$ & $\begin{array}{r}5 \\
2.906 \\
3.394 \\
0.489 \\
3.181 \\
0.052 \\
0.228 \\
0.102 \\
-0.377 \\
-1.745 \\
15.904 \\
0.072 \\
3.320\end{array}$ & $\begin{array}{r}3 \\
1.310 \\
1.860 \\
0.550 \\
1.493 \\
0.101 \\
0.318 \\
0.183 \\
0.707 \\
-1.500 \\
4.480 \\
0.213 \\
1.310\end{array}$ & $\begin{array}{r}35.500 \\
39.200 \\
3.700 \\
37.967 \\
4.563 \\
2.136 \\
1.233 \\
-0.707 \\
-1.500 \\
113.900 \\
0.056 \\
39.200\end{array}$ \\
\hline
\end{tabular}

THE FOLLOWING RESULTS ARE FOR:
SORWTGROS $X X V$

TOTAL OBSERVATIONS: 7

THE FOLLOWING RESULTS ARE FOR: SORWTGROS $=$ XXVII

TOTAL OBSERVATIONS: 18

TOCUGG LOGTOC GML $\quad H 2 O$

$\begin{array}{lrrrr}\text { N OF CASES } & 18 & 18 & 4 & 5 \\ \text { MINIMUM } & 40.000 & 1.602 & 1.410 & 52.670 \\ \text { MAXIMUM } & 28000.000 & 4.447 & 1.500 & 53.000 \\ \text { RANGE } & 27960.000 & 2.845 & 0.090 & 0.330 \\ \text { MEAN } & 3795.778 & 3.207 & 1.433 & 52.772 \\ \text { VARIANCE } & .469005 E+08 & 0.349 & 0.002 & 0.017 \\ \text { STANDARD DEV } & 6848.395 & 0.591 & 0.045 & 0.130 \\ \text { STD. ERROR } & 1614.182 & 0.139 & 0.023 & 0.058 \\ \text { SKEWNESS(G1) } & 2.867 & -0.425 & 1.155 & 1.342 \\ \text { KURTOSIS(G2) } & 7.140 & 2.092 & -0.667 & 0.078 \\ \text { SUM } & 68324.000 & 57.721 & 5.730 & 263.860 \\ \text { C.V } & 1.804 & 0.184 & 0.031 & 0.002 \\ \text { MEDIAN } & 1720.000 & 3.232 & 1.410 & 52.730\end{array}$


THE FOLLOWING RESULTS ARE FOR:

SORWTGROS $=X X X A$

TOTAL OBSERVATIONS: 2

\begin{tabular}{lrrrr} 
& \multicolumn{1}{c}{ TOCUGG } & \multicolumn{1}{l}{ LOGTOC } & \multicolumn{1}{l}{ GML } & \multicolumn{1}{l}{ H20 } \\
N OF CASES & \multicolumn{1}{c}{ r } & 2 & 2 & 2 \\
MINIMUM & 6230.000 & 3.794 & 1.540 & 43.000 \\
MAXIMUM & 7150.000 & 3.854 & 1.560 & 45.100 \\
RANGE & 920.000 & 0.060 & 0.020 & 2.100 \\
MEAN & 6690.000 & 3.824 & 1.550 & 44.050 \\
VARIANCE & 423200.000 & 0.002 & 0.000 & 2.205 \\
STANDARD DEV & 650.538 & 0.042 & 0.014 & 1.485 \\
STO. ERROR & 460.000 & 0.030 & 0.010 & 1.050 \\
SKEWNESS(G1) & 0.000 & 0.000 & 0.000 & 0.000 \\
KURTOSIS(G2) & -2.000 & -2.000 & -2.000 & -2.000 \\
SUM & 13380.000 & 7.649 & 3.100 & 88.100 \\
C.V. & 0.097 & 0.011 & 0.009 & 0.034 \\
MEDIAN & 6690.000 & 3.824 & 1.550 & 44.050
\end{tabular}

THE FOLLOWING RESULTS ARE FOR: SORWTGROS $=$ XXXC

TOTAL OBSERVATIONS: 1

$\begin{array}{llll}\text { TOCUGG LOGTOC } & \text { GML } & \text { H2O }\end{array}$

N OF CASES

MINIMUM

MAXIMUM

RANGE

MEAN

VARIANCE

STANDARD DEV

STD. ERROR

SKEWWESS (G1)

KURTOSIS(G2)

SUM

C. $V$.

MEDIAN

$\begin{array}{cc}1 & 1 \\ 4410.000 & 3.644 \\ 4410.000 & 3.644 \\ 0.000 & 0.000 \\ 4410.000 & 3.644 \\ : & \vdots \\ : & \vdots \\ 4 & . \\ 4410.000 & 3.644 \\ 0.000 & 0.000 \\ 4410.000 & 3.644\end{array}$

THE FOLLOWING RESULTS ARE FOR:

SORWTGROS $=$ XXXD

TOTAL OBSERVATIONS: 1

$\begin{array}{cccc}\text { TOCUGG } & \text { LOGTOC } & \text { GML } & \text { H2O } \\ 1 & 1 & 0 & 0 \\ 999.000 & 3.000 & : & : \\ 999.000 & 3.000 & : & : \\ 0.000 & 0.000 & : & : \\ 999.000 & 3.000 & : & : \\ : & : & : & : \\ : & : & : & : \\ 999.000 & 3.000 & : & : \\ 0.000 & 0.000 & : & : \\ 999.000 & 3.000 & : & :\end{array}$


THE FOLLOWING RESULTS ARE FOR:

SORWTGROS $=$ XXXF

TOTAL OBSERVATIONS: 17

\begin{tabular}{|c|c|c|c|c|}
\hline & TOCUGS & LOGTOC & GML & $\mathrm{H} 2 \mathrm{O}$ \\
\hline $\begin{array}{l}\text { N OF CASES } \\
\text { MINIMUMY } \\
\text { MAXIMUM } \\
\text { RANGE } \\
\text { MEAN } \\
\text { VARIANCE } \\
\text { STANDARD DEV } \\
\text { STO. ERROR } \\
\text { SKEWNESS (G1) } \\
\text { KURTOSIS(G2) } \\
\text { SUM } \\
\text { C.V. } \\
\text { MEDIAN }\end{array}$ & $\begin{array}{r}6 \\
100.000 \\
2900.000 \\
2800.000 \\
901.667 \\
1005416.667 \\
1002.705 \\
409.352 \\
1.593 \\
0.895 \\
5410.000 \\
1.112 \\
550.000\end{array}$ & $\begin{array}{r}6 \\
2.000 \\
3.462 \\
1.462 \\
2.761 \\
0.217 \\
0.466 \\
0.190 \\
-0.201 \\
-0.066 \\
16.564 \\
0.169 \\
2.740\end{array}$ & $\begin{array}{l}1.307 \\
1.307 \\
0.000 \\
1.307 \\
0.000 \\
0.000 \\
0.000 \\
0.000 \\
0.000 \\
2.614 \\
0.000 \\
1.307\end{array}$ & $\begin{array}{r}62.200 \\
62.200 \\
0.000 \\
62.200 \\
0.000 \\
0.000 \\
0.000 \\
0.000 \\
0.000 \\
124.400 \\
0.000 \\
62.200\end{array}$ \\
\hline
\end{tabular}

THE FOLLOWING RESULTS ARE FOR:

SORWTGROS $=X X X G$

TOTAL OBSERVATIONS: 2

TOCUGG LOGTOC GML H2O

$N$ OF CASES

MINIMUM

MAXIMUM

RANGE

MEAN

VARIANCE

STANDARD DEV

STD. ERROR

SKEWNESS (G1)

KURTOSIS(G2)

SUM

C.V.

MEDIAN

2
20.000
20.000
0.000
20.000
0.000
0.000
0.000
0.000
0.000
40.000
0.000
20.000

$1.640^{2}$

1.640
1.640

0.000

1.640

0.000

0.000

0.000

$43.500^{2}$

43.500

0.000
43.500

0.000

0.000

$0.000 \quad 0.000$

0.000

3.280

0.000

0.000

87.000

20.000

1.640

0.000 
Appendix D

Description of Sort on Radioactive Waste Types 


\section{Appendix D. Description of SORWT Waste Type Groups}

To further elaborate on the results of the SORWT Model, brief descriptions of each of the waste type groups predicted by the model have been developed.

\section{Group I - R, EB}

This waste type group is the most significant group predicted by SORWT in terms of number of tanks and total waste volume. The 22 tanks within this group contain $10,465,000$ gallons of total waste--8,884,000 gallons of salt cake and 1,440,000 gallons of sludge. All 22 Group I tanks can be found in three different 200 West Area Tank Farms--S, SX, and TX Farms. These tanks typically received a large amount of high-level REDOX waste (R) during the 1950s. This waste is most likely responsible for the sludge accumulation in these tanks. These tanks also received large amounts of evaporator bottoms (EB), usually from the 242-S Evaporator in the early 1970s. This super-saturated, high-nitrate waste cooled in the SSTs and formed an extremely hard salt cake. Although the processing history of these tanks between the addition of the $R$ in the 1950s and the EB in the 1970s differs slightly, it is believed that these two waste types predominantly dictate the physical and chemical characteristics of the waste. Some of the tanks in this group have no reported sludge accumulation, probably because poor measurements were taken before salt cake formation. Once the salt cake crystallized in a tank, it became impossible to measure the volume of sludge. Because of the extreme hardness of the salt cake, there are technical obstacles that prevent core sampling any of these tanks at this time.

\section{Group II - EB, 1C}

This 10-tank group contains approximately 4,634,000 gallons of waste. The vast majority of this waste--4,594,000 gallons--is salt cake. All but two of these tanks are located in the TX Tank Farm; one is located in B Tank Farm. These tanks are characterized as having received large quantities of EB, mainly from the 242-T Evaporator. They also received modest quantities of $1 \mathrm{C}$ waste. Tank B-105 received $1 \mathrm{C}$ before the $\mathrm{EB}$, which might explain the limited sludge accumulation in this tank that is not exhibited by the others. Once again, the hard salt cake formation raises significant technical issues that must be solved before sampling these tanks.

\section{Group III - TBP-F, EB-ITS}

This group contains 10 tanks and is the second most significant in terms of number of tanks and total waste volume. The tanks in this group hold 3,980,00 gallons of waste. The majority of this waste--3,344,000 gallons--is presumed to be salt cake. However, these tanks also contain substantial amounts of sludge. All 10 of these tanks, which originally held metal waste (MW) from the bismuth phosphate process, can be found in the BY Farm located in the 200 East Area. They were completely sluiced out in the early 1950s, and no significant amounts of MW remain in the tanks, so they are not considered by the SORWT model. After sluicing, these tanks received tributyl phosphate (TBP) ferrocyanide-scavenged 
waste from U Plant, which is probably responsible for the sludge buildup. During the late 1960s and early 1970s, these tanks were connected to the in-tank solidification (ITS-2) loops. This process, in which one tank in the loop was used as an in-tank evaporator and the rest of the tanks as liquid holders, concentrated the waste and reduced the liquid volume, resulting in salt cake formation. Because of high concentrations of ferrocyanide in these tanks and the hardness of the salt cake, there are significant safety and technical difficulties associated with sampling this waste type group.

\section{Group IV - TBP, CW}

This nine-tank group, located almost entirely in BX Tank Farm, contains 687,000 gallons of waste. Nearly all of the contents of this group is sludge. Salt cake has only been observed in one tank (BX-105), and the 3,000 gallons of salt cake is due to a small transfer of EB into that particular tank. These tanks were originally filled with MW in the 1940s. In the early 1950 s they were sluiced of their contents to provide room for TBP waste. Additions of this waste type began in the mid-1950s. The addition of cladding waste began in the mid-1960s. The various other transfers that occurred in these tanks should not affect the characteristic of the waste significantly relative to the primary and secondary wastes. Tanks BX-105 and Tank BX-106 were core sampled previously and provide insight into their chemical composition. Additional sampling of these tanks poses no technical or safety issues.

\section{Group V - 224}

This eight tank group represents 280,000 gallons of waste. The majority of the waste is sludge; no salt cake formation has been observed in these tanks. All eight tanks are 55,000-gallon, 200 Series tanks located in B and T Tank Farms. These tanks received 224 waste exclusively. In light of the singularity of the waste type introduced into these tanks and the similarity of process history (i.e., the near absence of any intertank transfers), the composition among tanks of this group should be very uniform. There are no safety or technical issues prohibiting sampling of these tanks.

\section{Group VI - R}

Group $\mathrm{V}$ is a seven-tank group containing high-level $\mathrm{R}$ exclusively. These tanks hold 892,000 gallons of waste. The majority of waste-- 888,000 gallons--is sludge, no salt cake formation has been observed. Five of these tanks can be found in the SX Tank Farm, and all are located in the 200 West Area. There are no safety or technical sampling issues associated with the majority of this group; the exception is Tank SX-109, which is on the watch list as a gas-generating tank. Sampling and analysis of S-104 has been performed; assessment of the data is currently pending and will contribute greatly to the existing body of characterization knowledge. The analysis of this tank significantly aids in characterizing this particular seven-tank group and also several other groups containing large amounts of R-type waste. It is of interest to note that $R$ forms sludge without any further waste volume reduction processes. 
Group VII - EB, R

Group VII consists of five 200 West Area tanks, mostly from U Farm. These tanks contain 2,037,000 gallons of waste, the vast majority of which is salt cake. The tanks were filled with MW in the 1940s, but were completely sluiced out in the early 1950s. Large quantities of high-level $\mathrm{R}$ were introduced into these tanks and allowed to remain there for many years. In the early $1970 \mathrm{~s}$, large volumes of $\mathrm{R}$ supernate were transferred from the tanks and replaced with EB from the 242-S Evaporator, which caused a salt cake to form in the majority of the tanks. The small amount of sludge that accumulated in these tanks is probably due to the $\mathrm{R}$ present before the EB. Because of the hardness of the salt cake, these tanks offer technical difficulties that must be solved before sampling. These tanks should be very similar to Group I tanks and differ from them mainly in the ratios of $R$ to $E B$. These tanks might be so similar that they can be included with that group; however, these similarities can only be verified by core samples.

Group VIII - TBP-F, 1C

This five-tank group contains 478,000 gallons of waste, and approximately 465,000 gallons of that is sludge. No salt cake has been observed in these tanks. The four C Farm tanks were used as the primary settling tanks during the In-Farm Scavenging campaign during the $1950 \mathrm{~s}$, and they were originally filled with $1 \mathrm{C}$ waste in the $1940 \mathrm{~s}$. The supernate was transferred out of the tanks to make room for the TBP-scavenged waste that was allowed to settle. These two wastes formed the vast majority of the solids located in these two tanks. The other tank in this group (T-107) has a processing history similar to that of the rest of this group, except that it received its ferrocyanide-scavenged TBP waste from the U Plant scavenge test. These two TBP-F wastes may be slightly different. All of these tanks are on the watch list because of their ferrocyanide content.

\section{Group IX - DSSF, NCPLX}

This four-tank group contains a total of 2,113,000 gallons of waste. Salt cake comprises $1,717,000$ gallons of this waste, while 387,000 gallons are sludge. These tanks initially received either plutonium-uranium extraction (PUREX) high-activity, neutralized acid waste (P) or B Plant high-level waste (B). However, all of these tanks were sluiced of their contents in 1976. The waste types added to these tanks after sluicing were DSSF and noncomplexed waste, which are generic terms describing the potential for further processing of the waste instead of the original source of the waste. Because these terms are so general, little can be determined about the homogeneity of the waste in this group. In fact, one tank in this group contains only sludge, while the rest contain mostly salt cake. Although the total volume of this group is highly significant, the uncertainty of the waste types in these tanks makes this group less important. 
These four tanks (all in U Farm) contain 1,755,000 gallons of waste. Salt cake comprises $1,520,000$ gallons of this waste, while sludge comprises only 124,000 gallons. These tanks were filled with MW in the late 1940s or early 1950s; in the mid- to late 1950s, the MW was sluiced from the tank to provide room for $\mathrm{CW}$. The supernatant portions of the $\mathrm{CW}$ were flushed out of the tanks in the early 1970 s by various liquid transfers. In the midto late 1970s, large amounts of EB from the REDOX evaporator and the 242-S Evaporator were added to these tanks. (The EB are responsible for the salt cake formation.) All of the tanks are on the watch list for either gas generation or acetate contents; therefore, there are safety and technical issues pertaining to sampling this tank.

\section{Group XI - 1C, TBP}

This five-tank group contains 715,000 gallons of waste, the vast majority of which is sludge. Even though this group transcends four different tank farms in both the 200 East and West Areas, these tanks have very similar processing histories. They were filled with 1C waste in the 1940s. A portion of this volume was drained in the early 1950 s, and the tanks began receiving TBP waste. The solids volume that was measured at this time did not accumulate further during the rest of these tanks' histories. The additional transfers were mostly liquid in nature and had little effect on the sludge volume. No salt cake has been observed in these tanks, even though a small amount of EB was introduced into T-108 (apparently not enough to catalyze crystallization).

\section{Group XII - 1C, EB}

This four-tank group of B and BX Farm tanks contains 553,000 gallons of waste, nearly all of which is sludge. These tanks all received $1 \mathrm{C}$ waste in the late 1940s and early 1950s. In the mid-1950s the supernatant portion of the $1 \mathrm{C}$ waste was transferred from the tanks and they began receiving EB waste. The EB must not have been very concentrated, because the characteristic salt cake did not form. All of these tanks also received appreciable amounts of CW in the 1960s.

\section{Group XIII - HS}

This four-tank group of 55,000-gallons, 200-Series tanks is located in the C Tank Farm. These tanks received MW in the 1940s but were sluiced in the early 1950s. After sluicing, these tanks received waste only from the Hot Semiworks. The majority of this waste was removed from these tanks in the late 1960s and early 1970s; the total waste remaining is only 11,000 gallons. This minor volume designates this tank group as being insignificant compared with other groups or even single tanks. 
This three-tank group contains 904,000 gallons of total waste. The majority of which, 892,000 gallons, is sludge. These SSTs were connected in a three-tank cascade. The processing history of these tanks is very similar. They all received $2 \mathrm{C}$ waste in the 1940 s and early 1950s until the cascade was full. In 1952, they began receiving 224 waste, and the excess supernate was cascaded to a crib. The first two tanks in the cascade (T-110 and $\mathrm{T}-111)$ received only these two wastes. Tank $\mathrm{T}-112$ received dilute decontamination waste (DW) and a mixture of liquid wastes in the late 1960s and early 1970s. These transfers would not have significantly altered the characteristics of the waste relative to the first two waste types. Tank T-110 is on the watch list for gas generation.

Group XV - 2C, 5-6

This three-tank group, located in the B Tank Farm of the 200 East Area, contains 516,000 gallons of waste. The majority of waste--511,000 gallons--is sludge. These three tanks also were connected in a three-tank cascade. The cascade was originally filled with $2 \mathrm{C}$ waste in the 1940 s, cribbed in 1950 , and refilled with $2 \mathrm{C}$ waste. The continuous overflow in B-112 was cribbed. The cascade began receiving 5-6 waste from B Plant in 1952 and fission products in 1963. The cascade received B Plant low-level waste (BL) and ion exchange waste (IX) in the late 1960s and early 1970s, but these were mostly liquid in nature and are not considered significant contributors to the physical and chemical characteristics of the solids remaining in the tank, relative to the previous three wastes. Tank B-112 received EB and recycle from the ITS loop. This EB-ITS waste did not cause the formation of salt cake typically exhibited by this waste form. Seven cores from Tank B-110 were obtained in 1989 and 1990 as part of Phase 1A and 1B of the Waste Characterization Program. These core samples underwent extensive analytical testing and provide excellent data for physical and chemical characterization of this group.

\section{Group XVI - R, RIX}

Group XVI consists of three SX farm tanks, which hold 368,000 gallons of waste. All of this waste is sludge. These tanks received REDOX high-level waste after they were released to operations in the mid- to late 1950 s. These tanks received only $R$ until the early 1970s, when RIX was introduced. In the mid- to late 1970s, these tanks received minor quantities of various waste types, mostly liquid in nature. Tank SX-114 received a small amount of EB waste but not in sufficient concentrations to catalyze crystal formation.

\section{Group XVII - 1C, CW}

This three-tank group contains 305,000 gallons of waste, the majority of which-303,000 gallons is sludge. No salt cake has been observed in these tanks. These tanks initially received $2 \mathrm{C}$ waste in 1947 . The cascade was then filled with $1 \mathrm{C}$ waste from 1948 until 1955 and then began receiving CW in large quantities. A large amount of solids accumulated from these three waste types. In the 1970s, a number of different liquid wastes were transferred through these three tanks, but these wastes did not affect the solids content to the degree of the previous three wastes. 
This three-tank group contains 204,000 gallons of waste, the vast majority of which is sludge; but 10,000 gallons of salt cake has formed in one of the tanks. These tanks also were connected in a three-tank cascade. The cascade was originally filled with MW in the 1940s and, as was typical with MW, sluiced out in the early 1950s. The cascade then began receiving evaporated cladding waste $(\mathrm{CW})$. Apparently the $\mathrm{CW}$ was not concentrated to the point of salt cake formation because of the limited amount of this waste form observed in the tank. The cascade also received unconcentrated CW in the 1960 s. These tanks received BL and IX in the 1970 s, but these predominantly liquid wastes are not considered to have contributed significantly to the solids formation in the tank.

\section{Group XIXX - CW, MIX}

This three-tank cascade currently holds 192,000 gallons of waste, most of which (145,000 gallons) is sludge. No salt cake has been observed in these tanks. The cascade was initially filled with MW in the 1940s and emptied in 1951. Tank T-101 received a small amount of TBP-scavenged waste from a plant pilot test of the process; this waste was then flushed from the tank. The cascade was again filled with MW in 1955 but emptied the following year. Tank T-101 is listed as a ferrocyanide tank, but this waste was removed, and the tank was effectively sluiced twice afterwards, so it is unlikely that any appreciable amount of ferrocyanide remains. The empty cascade was then filled with CW beginning in 1957. This single waste type remained until the early 1970 s, when a mixture of liquid waste was flushed through this cascade. The liquid wastes are considered to have had only a limited impact on the characteristics of the solid waste remaining in the tank.

\section{Group XX - CW}

These three 200-Series tanks from U Farm contain only 13,000 gallons of waste. The history of these tanks indicates that the predominant waste type is $\mathrm{CW}$. The insignificant amount of waste contained in these tanks makes this group virtually irrelevant.

\section{Group XXI-TBP,EB-ITS}

This pair of BY Farm tanks contains a combined total of 907,000 gallons of waste. The majority of this waste--771,000 gallons--is salt cake, while 87,000 gallons is sludge. Both tanks received MW before 1955 but were sluiced of their contents. Beginning in 1955 , both tanks received TBP waste. Both tanks received quantities of CW in the early 1960 s and were connected to an ITS loop in the late 1960s. Tank BY-102 belonged to ITS-1, and BY-109 belonged to ITS-2. Despite being connected to different ITS loops (and operated by different principles), the solids remaining in the two tanks can be expected to be relatively similar. These tanks both received TBP and CW before ITS. The hardness of the salt cake will prohibit sampling until a hard cake sampler is developed. 


\section{Group XXII - EB, TBP}

This pair of TX Farm tanks contains 481,000 gallons of waste, and all of it is salt cake. The processing history of these two tanks is slightly different; however, the major waste types are the same. Tank TX-108 received MW in the late 1940s, which was sluiced out in the early 1950s. A minor quantity of $R$ waste was introduced into this tank in the mid-1950s. On top of this $\mathrm{R}$ heel, a substantial amount of TBP waste was added.

Tank TX-118 received $1 \mathrm{C}$ waste in the early 1950 s. Most of this waste type was transferred out of the tank, and the TBP waste was added on top of this heel. In the late 1960s and early 1970s, significant quantities of EB from the 242-T Evaporator were added to both of these tanks, causing salt cake formation. Tank TX-118 is on the watch list because of transfers of ferrocyanide-scavenged waste.

\section{Group XXIII - SRS, SL-WASH}

Both of the tanks in this group are located in C Farm and contain 429,000 gallons of waste, the bulk of which--372,000 gallons--is sludge. This group received MW in the 1940s, but this waste was removed from these tanks in the early 1950s. The tanks were then filled with TBP waste. During the 1960 s, these tanks received various quantities of $\mathrm{P}$ and $\mathrm{CW}$. In the early 1970 s, these tanks received large quantities of a highly mixed liquid waste, which was later transferred out. This liquid probably did not greatly affect the solids. In 1976 and 1977, these tanks received a large transfer of strontium leached sludge (SRS), which greatly added to the solids volume in the tank. These tanks also received a large quantity of high-level solids as suspended particulates from a sludge wasting campaign in the AR vault. These suspended solids settled in the tanks and are considered a significant contributor to the solids characteristics and high radioactivity. Both of the tanks were previously core sampled. Tank $\mathrm{C}-103$ is on the watch list as an "organic" tank, because it has a separate organic liquid layer. Tank C-106 is on the same list as a "high heat" tank.

\section{Group XXIV - 1C, EB-ITS}

The two BX Farm tanks contain 429,000 gallons of waste--152,000 gallons of salt cake and 257,000 gallons of sludge. Both of these tanks received $1 \mathrm{C}$ waste in the late 1940 s and early 1950s. Tank BX-110 received some EB in the mid- to late 1950s. Both tanks received CW and IX wastes in the 1960s before receiving EB from one of the ITS loops. The physical forms of the waste, as reported by Hanlon (1990), are very different for these two tanks. The majority of BX-110 is sludge, and only 9,000 gallons $(\approx 31 / 4 \mathrm{in}$.) is salt cake. Tank BX-111 exhibits a greater amount of salt cake (143,000 gallons) than sludge $(68,000$ gallons). These differences in the reported physical form might result from imprecise sludge measurements during the early history of these tanks, or it might be the consequence of real differences between the tanks. This question cannot be answered until one or both of the tanks has been core sampled. 


\section{Group XXV - TBP}

This pair of TY Farm tanks contains 248,000 gallons of waste, all of which is sludge. These tanks had a very simple processing history; they received only one waste type--TBP. These tanks have been previously core sampled.

Group XXVI - TBP, EB

This pair of 200 West Area tanks hold a total of 215,000 gallons of waste, all of which is sludge. Although these tanks received an appreciable amount of evaporative bottoms (EB), the characteristic salt cake did not form.

\section{Group XXVII - TBP, 1C}

This pair of ferrocyanide tanks is located in TY Farm and contains 208,000 gallons of waste. The majority of waste--205,000 gallons--is sludge. No salt cake has been observed in these tanks. These tanks received TBP waste in the early 1950s, then during the mid-1950s, the supernate was transferred out and ferrocyanide-scavenged 1C waste placed on top of the TBP heel. These two waste types caused significant solids accumulation. During the 1960s and 1970s, a variety of waste was transferred into and out of these tanks. The solids accumulation did not substantially change during these transfers; therefore, these later transfers are not considered to have affected the physical and chemical characteristics of the solids already present in the tank. Both of these tanks have been previously sampled.

\section{Group XVIII - CCPLX, DSSF}

This group of two AX Farm tanks contains 151,000 gallons of waste, consisting of 40,000 gallons of salt cake and 9,000 gallons of sludge, with the remainder supernatant liquid. Both of these tanks were sluiced of their contents in 1977, leaving a 6,000-gallon heel of $P$ waste. The tanks then received wastes identified by unspecific waste names like concentrated complexed waste (CCPLX), double-shell slurry feed (DSSF), and evaporator feed (EVAP). Using such broad waste identifiers--based on suitability for further treatment, not waste source--precludes grouping by radioactive waste type.

\section{Group XXIX - R, DIA}

This pair of assumed leaker tanks contains 148,000 gallons of waste, all of which is sludge. Tank U-104 initially received MW in the 1940s, but this waste type was sluiced from the tank in the early 1950s. Tank SX-113 was not released to operation until the mid-1950s. Both tanks exclusively received $R$ after 1958 . Diatomaceous earth was added to both tanks after they were declared leakers, in an attempt to prevent the escape of liquid waste. 


\section{Group XXX - Solitary Tanks (Ungrouped)}

Of the 149 SSTs, only 19 did not fall into groups based on radioactive waste types. These 19 tanks transcend almost every waste type and every tank farm in the 200 East and West Areas. They contain mostly sludge. These ungrouped tanks represent $2,461,000$ gallons of waste-- 69,000 gallons of salt cake and 2,377,000 gallons of sludge. Several of these tanks have significant quantities of waste in them, and others have relatively little waste. Many of these tanks might also be related to some of the groups previously described. 
Appendix E

Analytical Techniques for Percent Water and TOC Measurements 


\section{Appendix E}

\section{Measurement of Total Organic Carbon-}

Measurement of TOC may be broken down into two major steps: sample preparation and analyte measurement. Both of these steps affect how much of the actual TOC is detected.

\section{TOC Sample Preparation}

TOC measurements are made on the soluble TOC fractions. Because TOC is not directly measured from solid phase waste tank waste samples, these are leached or digested first. The three preparation methods that have typically been used are water digestion, acid digestion, persulfate digestion, and fusion. Note that using a different preparatory method on the same sample will result in different TOC values measured even with the same analytical test.

Direct Measurement - No sample preparation i needed if the sample is liquid.

Water Digestion- The sample is leached with water to dissolve the water soluble portion of the waste into solution. Any non-water soluble portion is consequently not measured.

Acid Digestion - A variety of different acids have been used for acid digestion. Some, such as nitric acid have additional properties. Inorganic carbon is converted to carbon dioxide in this step ,thus removed from the sample.

Persulfate: The solid sample is dissolved/digested in hot $\left(+90^{\circ} \mathrm{C}\right)$ to liberate carbonate (inorganic carbon). Subsequentiy, potassium persulfate is added to convert the organic carbon to carbon dioxide, which is measured coulometrically.

Fusion - This is a multistep process. First, the potassium hydroxide is used to digest the waste sample; this step effectively decomposes the organic chemicals. The material from this step is then acidified.

\section{Analytic Technique for Measurement of TOC}

Combustion - This process is typically used with acid digestion preparation to first remove the inorganic carbon. First, the samples are oxidized to convert the organic forms of carbon to carbon dioxide. The combustion temperature is selected to oxidize the organic carbon components. The combustion products are swept through a catalyst and scrubbed to insure complete oxidation of the carbon to carbon dioxide. The quantity of carbon dioxide in the gas phase is measured as the indicator of TOC.

Chemical Oxidation/Coulometric - Samples are oxidized with potassium persulfate or potassium permaganate followed by coulometric measurement of the carbon dioxide gas, to indicate sample TOC. 


\section{Analytic Measurement of Percent Water}

Weight percent water may be measured in a number of ways. In many cases,. the data reports do not specify the method used. The two methods used in the majority of cases are described below.

Thermalgravimetric (TGA) analysis- A small sample, (10 mg) is heated at a constant rate while the weight loss is recorded. The loss in the region around 30 to 140 Celsius is attributed to water loss. Often the value reported is for a larger temperature range and is attributed to loss of both free water and waters of hydration.

Gravimetric analysis - A weighed sample is heated at a constant temperature (120 degrees celsius) until no further loss occurs. All weight loss is attributed to water. The weight percent water obtained by this method is consistently lower than by the TGA method. 
Appendix F

Laboratory Measurement Sample Dataset 


\section{TOC and Moisture Measurements}

\begin{tabular}{|c|c|c|c|c|c|c|c|}
\hline Tank & $\begin{array}{c}\text { Sample } \\
\text { ID }\end{array}$ & $\begin{array}{l}\text { Waste } \\
\text { Phase }\end{array}$ & $\begin{array}{l}(\mathrm{g} / \mathrm{mL}) \\
\text { Density }\end{array}$ & $\% \mathrm{H}_{2} \mathrm{O}$ & $\% \mathrm{TOC}$ & $\begin{array}{c}\text { Dry } \\
\% \text { TOC }\end{array}$ & $\begin{array}{l}\text { Ref. } \\
\text { Date }\end{array}$ \\
\hline A101. & 4218 & Liquid & $\mathrm{NA}$ & $\mathrm{NA}$ & 1.2083 & $\mathrm{NA}$ & $9 / 22 / 80$ \\
\hline A101 & 4378 & Liquid & $\mathrm{NA}$ & $\mathrm{NA}$ & 0.8864 & NA & $9 / 22 / 80$ \\
\hline A101 & 4493 & Sludge & NA & NA & 0.7609 & NA & $9 / 22 / 80$ \\
\hline A101 & 7879 & Liquid & 1.4 & $\mathrm{NA}$ & 0.3840 & NA & $10 / 10 / 83$ \\
\hline A101 & 7898 & Liquid & 1.7 & $\mathrm{NA}$ & 0.6530 & $\mathrm{NA}$ & $10 / 11 / 83$ \\
\hline A101 & RAT-A101-1 & Liquid & 1.3 & 45.42 & 0.8201 & 1.50 & $10 / 13 / 80$ \\
\hline A101 & RAT-A101-2 & Liquid & 1.3 & 45.49 & 0.9021 & 1.65 & $10 / 13 / 80$ \\
\hline A101 & RAT-A101-3 & Liquid & 1.5 & 46.10 & 1.3218 & 2.45 & $10 / 22 / 80$ \\
\hline A101 & RAT-A101-4A & Salt & 1.6 & 42.37 & 0.5764 & 1.00 & $11 / 10 / 80$ \\
\hline A101 & RAT-A101-4B & Liquid & 1.4 & 48.26 & 0.5109 & 0.99 & $11 / 10 / 80$ \\
\hline A101 & RAT-A101-5A & Salt & 1.9 & 34.19 & 0.8438 & 1.28 & $11 / 11 / 80$ \\
\hline A101 & RAT-A101-5B & Liquid & 1.5 & 34.86 & 0.6855 & 1.05 & $11 / 11 / 80$ \\
\hline $\mathrm{A} 101$ & RAT-A101-7B & Liquid & 1.4 & 50.25 & 1.4514 & 2.92 & $11 / 2 / 79$ \\
\hline A101 & $\mathrm{T}-2691$ & Liquid & 1.3 & 63.92 & 2.7439 & 7.60 & $8 / 22 / 80$ \\
\hline A101 & $\mathrm{T}-2692$ & Liquid & 1.3 & 65.86 & 3.3641 & 9.85 & $8 / 22 / 80$ \\
\hline $\mathrm{A} 102$ & $91 \mathrm{DX} 00 \mathrm{XX}$ & Liquid & 1.5 & 48.90 & 0.5303 & 1.04 & $3 / 6 / 86$ \\
\hline A102 & $91 \mathrm{XC} 00 \mathrm{XX}$ & Sludge & 1.5 & 40.92 & 0.7200 & 1.22 & $3 / 6 / 86$ \\
\hline A102 & $92 \mathrm{DX} 00 \mathrm{XX}$ & Liquid & 1.5 & 49.60 & 0.5086 & 1.01 & $3 / 8 / 86$ \\
\hline A102 & $92 \mathrm{XC} 00 \mathrm{XX}$ & Sludge & 1.7 & 29.40 & 0.7940 & 1.12 & $3 / 8 / 86$ \\
\hline A 102 & R-4656 & Liquid & NA & NA & 0.9610 & NA & $3 / 14 / 89$ \\
\hline $\mathrm{A} 102$ & RAT-A102-1 & Liquid & NA & $\mathrm{NA}$ & 0.1243 & NA & $12 / 23 / 80$ \\
\hline $\mathrm{A} 102$ & RAT-A102-3 & Liquid & NA & $\mathrm{NA}$ & 0.2114 & NA & $10 / 23 / 79$ \\
\hline A102 & RAT-A102-4 & Liquid & NA & $\mathrm{NA}$ & 0.3500 & NA & $3 / 14 / 79$ \\
\hline A 102 & $\mathrm{~T}-1243$ & Liquid & NA & NA & 0.0000 & NA & $7 / 17 / 80$ \\
\hline $\mathrm{A} 102$ & $\mathrm{~T}-1244$ & Liquid & NA & NA & 0.3508 & NA & $7 / 17 / 80$ \\
\hline A102 & $\mathrm{T}-1245$ & Liquid & $\mathrm{NA}$ & $\mathrm{NA}$ & 0.2925 & $\mathrm{NA}$ & $7 / 17 / 80$ \\
\hline $\mathrm{A} 102$ & $\mathrm{~T}-2404$ & Liquid & NA & $\mathrm{NA}$ & 0.4932 & NA & $8 / 4 / 80$ \\
\hline $\mathrm{A} 102$ & $\mathrm{~T}-2405$ & Liquid & NA & $\mathrm{NA}$ & 0.5288 & NA & $8 / 4 / 80$ \\
\hline A102 & T-6176 & Liquid & NA & NA & 0.4020 & NA & $12 / 8 / 79$ \\
\hline A 102 & RAT-A102-2 & Liquid & NA & 41.46 & NA & $\mathrm{NA}$ & $12 / 23 / 80$ \\
\hline A 103 & B1XC00XX & Sludge & 1.3 & 40.10 & 0.8040 & 1.34 & $3 / 26 / 86$ \\
\hline A103 & B1XD00XX & Liquid & 1.5 & 50.90 & 0.5664 & 1.15 & $3 / 26 / 86$ \\
\hline A103 & $\mathrm{B} 2 \mathrm{XC} 00 \mathrm{XX}$ & Sludge & 1.4 & 40.30 & 0.7730 & 1.29 & $4 / 3 / 86$ \\
\hline A103 & B2XD00XX & Liquid & 1.5 & 51.00 & 0.5581 & 1.14 & $4 / 3 / 86$ \\
\hline A103 & RAT-A103-5 & Liquid & NA & $\mathrm{NA}$ & 0.3531 & $\mathrm{NA}$ & $10 / 2 / 80$ \\
\hline A103 & RAT-A103-6 & Liquid & $\mathrm{NA}$ & $\mathrm{NA}$ & 1.0028 & $\mathrm{NA}$ & $9 / 22 / 80$ \\
\hline A103 & RAT-A103-7 & Liquid & NA & 53.00 & 1.1016 & NA & $8 / 2 / 79$ \\
\hline A103 & $\mathrm{T}-8951$ & Liquid & NA & NA & 0.6387 & $\mathrm{NA}$ & $3 / 19 / 80$ \\
\hline A106 & A1XC00XX & Sludge & 1.6 & 45.10 & 0.6230 & 1.13 & $3 / 11 / 86$ \\
\hline A106 & A1XD00XX & Liquid & 1.4 & 52.40 & 0.4178 & 0.88 & $3 / 11 / 86$ \\
\hline
\end{tabular}

F.1 


\begin{tabular}{|c|c|c|c|c|c|c|c|}
\hline Tank & $\begin{array}{c}\text { Sample } \\
\text { ID }\end{array}$ & $\begin{array}{l}\text { Waste } \\
\text { Phase }\end{array}$ & $\begin{array}{l}(\mathrm{g} / \mathrm{mL}) \\
\text { Density }\end{array}$ & $\% \mathrm{H}_{2} \mathrm{O}$ & $\%$ TOC & $\begin{array}{c}\text { Dry } \\
\% \text { TOC }\end{array}$ & $\begin{array}{c}\text { Ref. } \\
\text { Date }\end{array}$ \\
\hline A106 & $\mathrm{A} 2 \mathrm{XC} 00 \mathrm{XX}$ & Sludge & 1.5 & 43.00 & 0.7150 & 1.25 & $3 / 13 / 86$ \\
\hline A106 & $\mathrm{A} 2 \mathrm{XD} 00 \mathrm{XX}$ & Liquid & 1.4 & 51.50 & 0.0096 & 0.02 & $3 / 13 / 86$ \\
\hline AX101 & 5169 & Liquid & 1.4 & 42.46 & 0.5348 & 0.93 & $10 / 7 / 80$ \\
\hline AX101 & RAT-AX101-2 & Liquid & 1.4 & 44.66 & 1.1029 & 1.99 & $11 / 11 / 80$ \\
\hline AX101 & RAT-AX101-3 & Liquid & 1.4 & 43.40 & 1.0784 & 1.91 & $11 / 11 / 80$ \\
\hline AX101 & $\mathrm{T}-3102$ & Liquid & 1.4 & 51.79 & 0.8997 & 1.87 & $8 / 19 / 80$ \\
\hline AX101 & T-3103 & Liquid & 1.5 & 47.82 & 0.7540 & 1.44 & $8 / 19 / 80$ \\
\hline AX102 & 7701 & Liquid & NA & $\mathrm{NA}$ & 0.9104 & $\mathrm{NA}$ & $2 / 22 / 80$ \\
\hline AX102 & RAT-AX102-1 & Liquid & NA & $\mathrm{NA}$ & 1.4465 & NA & $1 / 23 / 80$ \\
\hline $\mathrm{AX} 102$ & RAT-AX102-3 & Liquid & $\mathrm{NA}$ & NA & 2.8300 & $\mathrm{NA}$ & $11 / 14 / 88$ \\
\hline AX103 & 4516 & Liquid & $\mathrm{NA}$ & $\mathrm{NA}$ & 2.8000 & $\mathrm{NA}$ & $9 / 24 / 80$ \\
\hline AX103 & 7595 & Liquid & NA & NA & 0.3300 & NA & $3 / 14 / 79$ \\
\hline AX103 & S-1423 & Liquid & NA & 47.02 & 0.8518 & NA & $8 / 6 / 79$ \\
\hline AX103 & S-1439 & Liquid & NA & NA & 1.0352 & NA & $8 / 6 / 79$ \\
\hline B110 & C10COMP1 & Sludge & $\mathrm{NA}$ & $\mathrm{NA}$ & 0.0421 & $\mathrm{NA}$ & $2 / 2 / 91$ \\
\hline $\mathrm{B} 110$ & C10COMP1 & Sludge & NA & NA & 0.0463 & NA & $2 / 3 / 91$ \\
\hline B110 & C16COMP1 & Sludge & NA & $\mathrm{NA}$ & 0.0407 & NA & $2 / 6 / 91$ \\
\hline B110 & C16COMP1 & Sludge & NA & NA & 0.0457 & $\mathrm{NA}$ & $2 / 7 / 91$ \\
\hline B110 & C1COMP1 & Sludge & $\mathrm{NA}$ & NA & 0.0398 & NA & $1 / 1 / 91$ \\
\hline B110 & C1COMP1 & Sludge & $\mathrm{NA}$ & NA & 0.0439 & NA & $1 / 2 / 91$ \\
\hline B110 & C2COMP1 & Sludge & $\mathrm{NA}$ & NA & 0.0312 & NA & $1 / 9 / 91$ \\
\hline $\mathrm{B} 110$ & C2COMP1 & Sludge & $\mathrm{NA}$ & $\mathrm{NA}$ & 0.0328 & NA & $1 / 10 / 91$ \\
\hline B110 & C3COMP1 & Sludge & $\mathrm{NA}$ & $\mathrm{NA}$ & 0.0300 & $\mathrm{NA}$ & $1 / 13 / 91$ \\
\hline B110 & C3COMP1 & Sludge & $\mathrm{NA}$ & NA & 0.0358 & NA & $1 / 14 / 91$ \\
\hline B110 & C4COMP1 & Sludge & $\mathrm{NA}$ & NA & 0.0396 & $\mathrm{NA}$ & $1 / 25 / 91$ \\
\hline B110 & C4COMP1 & Sludge & $\mathrm{NA}$ & NA & 0.0456 & NA & $1 / 26 / 91$ \\
\hline B110 & C9COMP1 & Sludge & $\mathrm{NA}$ & NA & 0.0298 & $\mathrm{NA}$ & $1 / 29 / 91$ \\
\hline B110 & C9COMP1 & Sludge & $\mathrm{NA}$ & $\mathrm{NA}$ & 0.0304 & $\mathrm{NA}$ & $1 / 30 / 91$ \\
\hline B111 & C29COMP1 & Sludge & $\mathrm{NA}$ & NA & 0.0680 & $\mathrm{NA}$ & $9 / 3 / 91$ \\
\hline B111 & C29COMP1 & Sludge & NA & NA & 0.0820 & NA & $9 / 4 / 91$ \\
\hline B111 & C29COMP2 & Sludge & $\mathrm{NA}$ & $\mathrm{NA}$ & 0.0560 & NA & $9 / 1 / 91$ \\
\hline B111 & C29COMP2 & Sludge & $\mathrm{NA}$ & NA & 0.0670 & $\mathrm{NA}$ & $9 / 2 / 91$ \\
\hline B111 & C32COMP1 & Sludge & NA & NA & 0.1590 & NA & $9 / 7 / 91$ \\
\hline B111 & C32COMP1 & Sludge & $\mathrm{NA}$ & NA & -0.1620 & NA & $9 / 8 / 91$ \\
\hline $\mathrm{B} 111$ & C32COMP2 & Sludge & NA & $\mathrm{NA}$ & 0.1320 & $\mathrm{NA}$ & $9 / 5 / 91$ \\
\hline B111 & C32COMP2 & Sludge & $\mathrm{NA}$ & NA & 0.1340 & NA & $9 / 6 / 91$ \\
\hline B201 & 1898 & Sludge & $\mathrm{NA}$ & 72.20 & NA & NA & $12 / 4 / 78$ \\
\hline B202 & 2509 & Sludge & 1.3 & NA & 0.0030 & 0.01 & $12 / 4 / 78$ \\
\hline $\mathrm{B} 202$ & 2509 & Sludge & 1.3 & $\mathrm{NA}$ & 0.0060 & 0.01 & $12 / 4 / 78$ \\
\hline B202 & 2509 & Sludge & $\mathrm{NA}$ & 40.00 & $\mathrm{NA}$ & NA & $12 / 4 / 78$ \\
\hline
\end{tabular}




\begin{tabular}{|c|c|c|c|c|c|c|c|}
\hline Tank & $\begin{array}{c}\text { Sample } \\
\text { ID }\end{array}$ & $\begin{array}{l}\text { Waste } \\
\text { Phase }\end{array}$ & $\begin{array}{l}(\mathrm{g} / \mathrm{mL}) \\
\text { Density }\end{array}$ & $\% \mathrm{H}_{2} \mathrm{O}$ & $\% \mathrm{TOC}$ & $\begin{array}{c}\text { Dry } \\
\% \text { TOC }\end{array}$ & $\begin{array}{l}\text { Ref. } \\
\text { Date }\end{array}$ \\
\hline$\overline{B 202}$ & 2509 & Sludge & NA & 71.00 & NA & $\mathrm{NA}$ & $12 / 4 / 78$ \\
\hline B202 & C24COMP1 & Sludge & NA & NA & 0.1900 & NA & $6 / 15 / 91$ \\
\hline B202 & C24COMP1 & Sludge & $\mathrm{NA}$ & $\mathrm{NA}$ & 0.2200 & $\mathrm{NA}$ & $6 / 14 / 91$ \\
\hline B202 & C24COMP1 & Sludge & $\mathrm{NA}$ & $\mathrm{NA}$ & 3.1400 & $\mathrm{NA}$ & $6 / 12 / 91$ \\
\hline $\mathrm{B} 202$ & C24COMP1 & Sludge & NA & $\mathrm{NA}$ & 3.3200 & NA & $6 / 13 / 91$ \\
\hline B202 & C24COMP2 & Sludge & NA & NA & 0.1900 & NA & $6 / 9 / 91$ \\
\hline $\mathrm{B} 202$ & C24COMP2 & Sludge & NA & $\mathrm{NA}$ & 0.2200 & NA & $6 / 10 / 91$ \\
\hline B202 & C24COMP2 & Sludge & NA & $\mathrm{NA}$ & 0.3770 & NA & $6 / 11 / 91$ \\
\hline B202 & C25COMP1 & Sludge & NA & $\mathrm{NA}$ & 0.3360 & NA & $6 / 19 / 91$ \\
\hline $\mathrm{B} 202$ & C25COMP1 & Sludge & NA & $\mathrm{NA}$ & 0.3800 & $\mathrm{NA}$ & $6 / 21 / 91$ \\
\hline $\mathrm{B} 202$ & C25COMP2 & Sludge & NA & $\mathrm{NA}$ & 0.2100 & NA & $6 / 17 / 91$ \\
\hline $\mathrm{B} 202$ & C25COMP2 & Sludge & $\mathrm{NA}$ & NA & 0.2300 & NA & $6 / 18 / 91$ \\
\hline B202 & C25COMP2 & Sludge & NA & $\mathrm{NA}$ & 0.3650 & NA & $6 / 20 / 91$ \\
\hline B202 & composite & Sludge & NA & NA & 3.2300 & $\mathrm{NA}$ & $4 / 10 / 90$ \\
\hline B204 & 1974 & Sludge & 1.1 & $\mathrm{NA}$ & 0.1011 & 0.42 & $12 / 4 / 78$ \\
\hline B204 & 1974 & Sludge & NA & 76.00 & NA & NA & $12 / 4 / 78$ \\
\hline B204 & 1974 & Sludge & NA & 76.00 & NA & NA & $12 / 4 / 78$ \\
\hline BX104 & $71 \mathrm{XCOOXX}$ & Sludge & $\mathrm{NA}$ & $\mathrm{NA}$ & 0.1780 & $\mathrm{NA}$ & $2 / 14 / 86$ \\
\hline BX104 & $71 \mathrm{XD} 00 \mathrm{XX}$ & Liquid & NA & NA & 0.4718 & NA & $2 / 14 / 86$ \\
\hline BX104 & $72 \mathrm{XCOOXX}$ & Sludge & NA & $\mathrm{NA}$ & 0.2710 & $\mathrm{NA}$ & $2 / 26 / 86$ \\
\hline BX104 & 72XD00XX & Liquid & NA & NA & 0.4645 & NA & $2 / 26 / 86$ \\
\hline BX104 & RAT-BX104-1 & Sludge & $\mathrm{NA}$ & NA & 0.4400 & NA & $4 / 27 / 90$ \\
\hline BX104 & $\mathrm{T}-1785$ & Liquid & NA & NA & 0.7820 & $\mathrm{NA}$ & $8 / 14 / 80$ \\
\hline BX104 & $\mathrm{T}-9510$ & Liquid & NA & 87.97 & NA & NA & \\
\hline BX105 & $81 \mathrm{XCOOXX}$ & Sludge & NA & NA & 0.3760 & NA & $3 / 3 / 86$ \\
\hline BX105 & 81XD00XX & Liquid & $\mathrm{NA}$ & $\mathrm{NA}$ & 0.7070 & NA & $3 / 3 / 86$ \\
\hline BX105 & $82 \mathrm{XCOOXX}$ & Sludge & NA & NA & 0.1800 & NA & $3 / 4 / 86$ \\
\hline BX105 & 82XD00XX & Liquid & $\mathrm{NA}$ & $\mathrm{NA}$ & 0.7558 & $\mathrm{NA}$ & $3 / 4 / 86$ \\
\hline BX105 & T-8924 & Liquid & NA & 76.88 & NA & NA & \\
\hline BX106 & $\mathrm{R}-6037$ & Liquid & $\mathrm{NA}$ & $\mathrm{NA}$ & 0.3308 & NA & $3 / 16 / 90$ \\
\hline BX106 & $\mathrm{T}-3855$ & Liquid & NA & 57.80 & NA & NA & $4 / 21 / 85$ \\
\hline BX107 & C40COMP1 & Sludge & NA & NA & 0.0700 & NA & $8 / 4 / 94$ \\
\hline BX107 & C40COMP1 & Sludge & $\mathrm{NA}$ & $\mathrm{NA}$ & 0.0700 & $\mathrm{NA}$ & $8 / 5 / 94$ \\
\hline $\mathrm{BX} 107$ & C40COMP1 & Sludge & NA & 56.45 & NA & NA & $8 / 1 / 94$ \\
\hline BX107 & C40COMP2 & Sludge & NA & NA & 0.0550 & NA & $8 / 2 / 94$ \\
\hline BX107 & C40COMP2 & Sludge & NA & NA & 0.0550 & $\mathrm{NA}$ & $8 / 3 / 94$ \\
\hline BX107 & C40COMP2 & Sludge & NA & 63.50 & NA & NA & $8 / 1 / 94$ \\
\hline BX107 & $\mathrm{C} 40 \mathrm{~S} 2$ & Sludge & $\mathrm{NA}$ & 44.35 & NA & NA & $8 / 1 / 94$ \\
\hline BX107 & C40S4 & Sludge & NA & 51.30 & NA & NA & $8 / 1 / 94$ \\
\hline BX107 & C40S5 & Sludge & $\mathrm{NA}$ & 52.85 & NA & NA & $8 / 1 / 94$ \\
\hline
\end{tabular}




\begin{tabular}{|c|c|c|c|c|c|c|c|}
\hline Tank & $\begin{array}{c}\text { Sample } \\
\text { ID }\end{array}$ & $\begin{array}{l}\text { Waste } \\
\text { Phase }\end{array}$ & $\begin{array}{l}(\mathrm{g} / \mathrm{mL}) \\
\text { Density }\end{array}$ & $\% \mathrm{H}_{2} \mathrm{O}$ & $\%$ TOC & $\begin{array}{c}\text { Dry } \\
\% \text { TOC }\end{array}$ & $\begin{array}{l}\text { Ref. } \\
\text { Date }\end{array}$ \\
\hline$\overline{\mathrm{BX}}=\overline{07}$ & $\mathrm{C} 40 \mathrm{~S} 6$ & Sludge & $\mathrm{NA}$ & 46.10 & $\mathrm{NA}$ & $\mathrm{NA}$ & $8 / 1 / 94$ \\
\hline BX:07 & $\mathrm{C} 40 \mathrm{~S} 7$ & Sludge & $\mathrm{NA}$ & 49.60 & 0.0550 & 0.11 & $8 / 1 / 94$ \\
\hline BX107 & C41COMP1. & Sludge & $\mathrm{NA}$ & NA & 0.0500 & $\mathrm{NA}$ & $8 / 13 / 94$ \\
\hline BX」07 & C41COMP1 & Sludge & NA & $\mathrm{NA}$ & 0.0550 & $\mathrm{NA}$ & $8 / 14 / 94$ \\
\hline BX1.07 & C41COMP1 & Sludge & NA & 55.95 & NA & NA & $8 / 13 / 94$ \\
\hline BX1.07 & C41COMP1 & Sludge & NA & 64.50 & NA & NA & $8 / 6 / 94$ \\
\hline BX107 & C41COMP2 & Sludge & NA. & NA & 0.0897 & 0.19 & $8 / 7 / 94$ \\
\hline BX107 & C41COMP2 & Sludge & NA & NA & 0.0796 & $\mathrm{NA}$ & $8 / 15 / 94$ \\
\hline BX107 & $\mathrm{C} 41 \mathrm{COMP} 2$ & Sludge & NA & 52.50 & NA & $\mathrm{NA}$ & $8 / 7 / 94$ \\
\hline BX107 & $\mathrm{C} 41 \mathrm{~S} 2$ & Sludge & NA & 44.35 & NA & $\mathrm{NA}$ & $8 / 8 / 94$ \\
\hline BX1.07 & C41S3 & Sludge & NA & 53.30 & NA & NA & $8 / 9 / 94$ \\
\hline BX107 & C41S5 & Sludge & NA & 37.90 & NA & $\mathrm{NA}$ & $8 / 10 / 94$ \\
\hline BX107 & $\mathrm{C} 41 \mathrm{~S} 6$ & Sludge & NA & 41.20 & NA & NA & $8 / 11 / 94$ \\
\hline BX107 & C41S7 & Sludge & $\mathrm{NA}$ & 34.60 & NA & NA & $8 / 12 / 94$ \\
\hline BX107 & $\mathrm{R}-6038$ & Liquid & NA & NA & 0.2213 & NA & $3 / 16 / 90$ \\
\hline BX107 & RAT-BX107-2 & Salt & 1.5 & 53.70 & 0.0730 & 0.16 & $9 / 18 / 80$ \\
\hline BX1.09 & R-6039 & Liquid & NA & 59.80 & 0.2239 & $\mathrm{NA}$ & $3 / 16 / 90$ \\
\hline BX1.10 & $1010-\mathrm{C}$ & Sludge & NA & NA & 0.0700 & $\mathrm{NA}$ & $2 / 14 / 79$ \\
\hline $\mathrm{BX} 1.10$ & $\mathrm{R}-6040$ & Liquid & NA & $\mathrm{NA}$ & 0.4088 & $\mathrm{NA}$ & $3 / 16 / 90$ \\
\hline BX 110 & RAT-BX110-1 & Sludge & 1.5 & 51.90 & 0.0169 & 0.04 & $9 / 18 / 80$ \\
\hline BX111 & $\mathrm{R}-6041$ & Liquid & NA & 53.30 & 0.3958 & NA & $3 / 16 / 90$ \\
\hline BX111 & RAT-BX110-2 & Sludge & 1.5 & 51.90 & 0.0600 & 0.12 & $9 / 18 / 80$ \\
\hline BX112 & $\mathrm{R}-6042$ & Liquid & NA & NA & 0.3108 & NA & $3 / 16 / 90$ \\
\hline BX112 & RAT-BX112-1 & Sludge & NA & NA & 1.0150 & NA & $6 / 11 / 79$ \\
\hline BX112 & Table3.0.0-1 & Sludge & 1.4 & 57.47 & 0.1220 & 0.29 & $9 / 18 / 80$ \\
\hline BX112 & Table3.0.0-2 & Slụdge & 1.4 & 57.47 & 0.8930 & 2.10 & $9 / 18 / 80$ \\
\hline BY102 & $\mathrm{R}-8081$ & Liquid & NA & 54.00 & 0.1549 & $\mathrm{NA}$ & $6 / 3 / 91$ \\
\hline BY102 & R-8091 & Liquid & NA & NA & 0.1418 & NA & $6 / 3 / 91$ \\
\hline BY103 & $\mathrm{R}-8088$ & Liquid & NA & 52.00 & 0.1883 & $\mathrm{NA}$ & $6 / 3 / 91$ \\
\hline BY104 & riser $10 \mathrm{~b} /$ auger & Salt & NA & NA & 1.1000 & 1.29 & $5 / 2 / 93$ \\
\hline BY104 & riser $10 \mathrm{~b} /$ auger & Salt & NA & $\mathrm{NA}$ & 1.0750 & 1.29 & $5 / 4 / 93$ \\
\hline BY104 & riser $10 \mathrm{~b} /$ auger & Salt & $\mathrm{NA}$ & 15.00 & NA & NA & $5 / 2 / 93$ \\
\hline BY104 & riser $10 \mathrm{~b} /$ auger & Salt & NA & 15.00 & NA & NA & $5 / 4 / 93$ \\
\hline BY104 & riser5/auger & Salt & NA & NA & 0.6000 & 0.72 & $5 / 3 / 93$ \\
\hline BY104 & riser5/auger & Salt & NA & NA & 0.9100 & 1.08 & $5 / 1 / 93$ \\
\hline BY104 & riser5/auger & Salt & NA & 17.00 & NA & $\mathrm{NA}$ & $5 / 3 / 93$ \\
\hline BY104 & riser5/auger & Salt & $\mathrm{NA}$ & 17.00 & NA & NA & $5 / 1 / 93$ \\
\hline BY104 & RAT-BY-104 & Sludge & NA & 28.30 & NA & NA & $2 / 6 / 76$ \\
\hline BY1.05 & $\mathrm{R}-8082$ & Liquid & $\mathrm{NA}$ & NA & 0.2217 & NA & $6 / 3 / 91$ \\
\hline BY1.05 & $\mathrm{R}-8092$ & Liquid & NA & 54.00 & 0.1993 & NA & $6 / 3 / 91$ \\
\hline
\end{tabular}




\begin{tabular}{|c|c|c|c|c|c|c|c|}
\hline Tank & $\begin{array}{l}\text { Sample } \\
\text { ID }\end{array}$ & $\begin{array}{l}\text { Waste } \\
\text { Phase }\end{array}$ & $\begin{array}{l}(\mathrm{g} / \mathrm{mL}) \\
\text { Density }\end{array}$ & $\% \mathrm{H}_{2} \mathrm{O}$ & $\%$ TOC & $\begin{array}{c}\text { Dry } \\
\% \text { TOC }\end{array}$ & $\begin{array}{l}\text { Ref. } \\
\text { Date }\end{array}$ \\
\hline$\overline{B Y 106}$ & R-8083 & Liquid & $\mathrm{NA}$ & $\mathrm{NA}$ & 0.2247 & NA & $6 / 3 / 91$ \\
\hline BY106 & R-8093 & Liquid & NA & 50.00 & 0.2068 & $\mathrm{NA}$ & $6 / 3 / 91$ \\
\hline BY107 & S-1450 & Liquid & NA & NA & 0.3080 & NA & $7 / 16 / 79$ \\
\hline BY109 & & Liquid & NA & NA & 0.3700 & $\mathrm{NA}$ & $1 / 1 / 91$ \\
\hline BY109 & R-8084 & Liquid & NA & 58.00 & 0.3154 & NA & $6 / 3 / 91$ \\
\hline BY109 & R-8094 & Liquid & NA & NA & 0.3407 & $\mathrm{NA}$ & $6 / 3 / 91$ \\
\hline C102 & $\mathrm{R}-8089$ & Liquid & NA & NA & 0.2783 & $\mathrm{NA}$ & $6 / 3 / 91$ \\
\hline C103 & F1XCOOXX & Sludge & NA & NA & 0.3900 & NA & $5 / 7 / 86$ \\
\hline $\mathrm{C} 103$ & F1XD00XX & Liquid & NA & NA & 0.6640 & NA & $5 / 7 / 86$ \\
\hline C103 & F2XCOOXX & Sludge & NA & NA & 0.2630 & $\mathrm{NA}$ & $5 / 14 / 86$ \\
\hline C103 & F2XD00XX & Liquid & NA & NA & 0.6944 & NA & $5 / 14 / 86$ \\
\hline C103 & $\mathrm{R}-8108$ & Liquid & NA & NA & 0.6972 & NA & $6 / 3 / 91$ \\
\hline C103 & R-8109 & Liquid & NA & NA & 0.7019 & NA & $6 / 3 / 91$ \\
\hline C103 & riser2 & Liquid & $\mathrm{NA}$ & NA & 0.5700 & NA & $5 / 19 / 87$ \\
\hline C103 & riser8 & Liquid & $\mathrm{NA}$ & NA & 0.5500 & NA & $5 / 19 / 87$ \\
\hline C103 & T-9661 & Liquid & $\mathrm{NA}$ & 87.78 & NA & NA & $5 / 20 / 75$ \\
\hline C104 & D1XCOOXX & Sludge & NA & NA & 0.4410 & NA & $4 / 15 / 86$ \\
\hline C104 & D1XDOOXX & Liquid & $\mathrm{NA}$ & NA & 0.8729 & NA & $4 / 15 / 86$ \\
\hline C104 & $\mathrm{T}-225$ & Liquid & NA & 76.64 & NA & NA & $12 / 1 / 85$ \\
\hline C105 & C1XCOOXX & Sludge & $\mathrm{NA}$ & $\mathrm{NA}$ & 0.0999 & NA & $4 / 11 / 86$ \\
\hline C105 & C1XD00XX & Liquid & $\mathrm{NA}$ & NA & 0.2333 & NA & $4 / 11 / 86$ \\
\hline C106 & & Sludge & NA & NA & 0.0800 & NA & $5 / 8 / 87$ \\
\hline C106 & G1XCOOXX & Sludge & NA & NA & 0.4620 & NA & $5 / 19 / 86$ \\
\hline C106 & $\operatorname{glxdxxxx}$ & Liquid & NA & NA & 0.1900 & NA & $5 / 19 / 86$ \\
\hline C107 & R-8046 & Liquid & NA & $\mathrm{NA}$ & 0.0904 & NA & $6 / 3 / 91$ \\
\hline C109 & C47COMP1 & Sludge & NA & NA & 0.3000 & NA & $11 / 1 / 91$ \\
\hline C109 & C47COMP1 & Sludge & $\mathrm{NA}$ & NA & 0.3300 & NA & $11 / 2 / 91$ \\
\hline C109 & C48COMP1 & Sludge & $\mathrm{NA}$ & NA & 0.2900 & NA & $11 / 3 / 91$ \\
\hline C109 & C48COMP1 & Sludge & NA & NA & 0.3000 & $\mathrm{NA}$ & $11 / 4 / 91$ \\
\hline C109 & C49COMP1 & Sludge & NA & NA & 0.2100 & $\mathrm{NA}$ & $11 / 5 / 91$ \\
\hline C109 & C49COMP1. & Sludge & $\mathrm{NA}$ & NA & 0.2800 & NA & $11 / 6 / 91$ \\
\hline C109 & $\mathrm{T}-5490$ & Liquid & NA & 73.54 & NA & NA & \\
\hline C110 & C37COMP1 & Sludge & NA & NA & 0.0500 & $\mathrm{NA}$ & $8 / 1 / 92$ \\
\hline $\mathrm{C} 110$ & C37COMP1 & Sludge & NA & NA & 0.1050 & NA & $8 / 2 / 92$ \\
\hline C110 & C37COMP2 & Sludge & NA & NA & 0.1090 & NA & $8 / 3 / 92$ \\
\hline $\mathrm{C} 110$ & C37COMP2 & Sludge & NA & NA & 0.1090 & $\mathrm{NA}$ & $8 / 4 / 92$ \\
\hline C110 & C39COMP1 & Sludge & NA & NA & 0.0528 & NA & $8 / 7 / 92$ \\
\hline C110 & R-8087 & Liquid & NA & 75.00 & 0.0527 & NA & $6 / 3 / 91$ \\
\hline $\mathrm{C} 112$ & C34COMP & Sludge & NA & 38.00 & 0.3100 & 0.50 & $9 / 1 / 93$ \\
\hline C112 & C34COMP & Liquid & $\mathrm{NA}$ & $\mathrm{NA}$ & 0.2000 & NA & $9 / 1 / 93$ \\
\hline
\end{tabular}




\begin{tabular}{|c|c|c|c|c|c|c|c|}
\hline Tank & $\begin{array}{c}\text { Sample } \\
\text { ID }\end{array}$ & $\begin{array}{l}\text { Waste } \\
\text { Phase }\end{array}$ & $\begin{array}{l}(\mathrm{g} / \mathrm{mL}) \\
\text { Density }\end{array}$ & $\% \mathrm{H}_{2} \mathrm{O}$ & $\% \mathrm{TOC}$ & $\begin{array}{c}\text { Dry } \\
\% \text { TOC }\end{array}$ & $\begin{array}{l}\text { Ref. } \\
\text { Date }\end{array}$ \\
\hline $\mathrm{C} 112$ & C34COMP1 & Sludge & $\mathrm{NA}$ & NA & 0.3050 & $\mathrm{NA}$ & $9 / 3 / 93$ \\
\hline $\mathrm{C} 112$ & C34COMP1 & Sludge & NA & NA & 0.3200 & $\mathrm{NA}$ & $9 / 5 / 93$ \\
\hline $\mathrm{C} 112$ & C34S1D & Sludge & $\mathrm{NA}$ & 45.00 & 0.4900 & 0.89 & $9 / 7 / 93$ \\
\hline $\mathrm{C} 112$ & $\mathrm{C} 34 \mathrm{~S} 2 \mathrm{~B}$ & Sludge & NA & 53.00 & 0.3000 & 0.64 & $9 / 2 / 93$ \\
\hline $\mathrm{C} 112$ & $\mathrm{C} 34 \mathrm{~S} 2 \mathrm{C}$ & Sludge & $\mathrm{NA}$ & 58.00 & 0.3100 & 0.74 & $9 / 4 / 93$ \\
\hline $\mathrm{C} 112$ & C34S2D & Sludge & NA & 52.00 & 0.4000 & 0.83 & $9 / 6 / 93$ \\
\hline $\mathrm{C} 112$ & C35COMP & Liquid & $\mathrm{NA}$ & 34.00 & 0.1200 & 0.18 & $9 / 1 / 93$ \\
\hline $\mathrm{C} 112$ & C35COMP1 & Sludge & NA & NA & 0.2200 & NA & $9 / 8 / 93$ \\
\hline $\mathrm{C} 112$ & C35COMP1 & Sludge & NA & NA & 0.2900 & NA & $9 / 10 / 93$ \\
\hline $\mathrm{C} 112$ & C35S2D & Sludge & NA & 34.00 & 0.2600 & 0.38 & $9 / 9 / 93$ \\
\hline $\mathrm{C} 112$ & C36COMP & Sludge & $\mathrm{NA}$ & 45.00 & 0.1400 & 0.25 & $9 / 11 / 93$ \\
\hline $\mathrm{C} 112$ & C36S1C & Sludge & NA & 49.00 & 0.8200 & 1.61 & $9 / 17 / 93$ \\
\hline $\mathrm{C} 112$ & C36S1D & Sludge & NA & 58.00 & 0.3900 & 1.17 & $9 / 16 / 93$ \\
\hline C112 & C36S2A & Sludge & $\mathrm{NA}$ & 57.00 & 0.3900 & 0.91 & $9 / 15 / 93$ \\
\hline $\mathrm{C} 112$ & C36S2B & Sludge & $\mathrm{NA}$ & 41.00 & 0.2700 & 0.46 & $9 / 13 / 93$ \\
\hline $\mathrm{C} 112$ & $\mathrm{C} 36 \mathrm{~S} 2 \mathrm{C}$ & Sludge & NA & 64.00 & 0.2900 & 0.81 & $9 / 14 / 93$ \\
\hline $\mathrm{C} 112$ & C36S2D & Sludge & $\mathrm{NA}$ & 56.00 & 0.2300 & 0.52 & $9 / 12 / 93$ \\
\hline C112 & $\mathrm{T}-6185$ & Liquid & NA & 78.49 & NA & $\mathrm{NA}$ & $11 / 20 / 74$ \\
\hline $\mathrm{C} 201$ & $\mathrm{~T}-3421$ & Sludge & NA & 68.00 & 0.2071 & NA & $12 / 4 / 78$ \\
\hline $\mathrm{S} 102$ & & Liquid & NA & NA & 2.4200 & $\mathrm{NA}$ & $1 / 1 / 80$ \\
\hline $\mathrm{S} 102$ & RAT-S102-3 & Liquid & 1.3 & 61.74 & 0.8433 & 2.20 & $1 / 31 / 79$ \\
\hline $\mathrm{S} 102$ & $\mathrm{~T}-7300$ & Liquid & NA & 60.48 & NA & NA & $10 / 14 / 74$ \\
\hline S104 & C42COMP1 & Sludge & NA & NA & 0.2190 & $\mathrm{NA}$ & $8 / 3 / 92$ \\
\hline S104 & C42COMP1 & Sludge & NA & NA & 0.2380 & NA & $8 / 4 / 92$ \\
\hline S104 & C42COMP2 & Sludge & NA & NA & 0.1300 & NA & $8 / 1 / 92$ \\
\hline S104 & C42COMP2 & Sludge & $\mathrm{NA}$ & $\mathrm{NA}$ & 0.1300 & $\mathrm{NA}$ & $8 / 2 / 92$ \\
\hline S104 & C43COMP1 & Sludge & $\mathrm{NA}$ & $\mathrm{NA}$ & 0.2060 & NA & $8 / 7 / 92$ \\
\hline S104 & C43COMP1 & Sludge & NA & NA & 0.2350 & NA & $8 / 8 / 92$ \\
\hline S104 & C43COMP2 & Sludge & NA & NA & 0.1090 & $\mathrm{NA}$ & $8 / 5 / 92$ \\
\hline S104 & C43COMP2 & Sludge & NA & NA & 0.1190 & NA & $8 / 6 / 92$ \\
\hline S104 & C44COMP2 & Sludge & NA & NA & 0.1100 & $\mathrm{NA}$ & $8 / 9 / 92$ \\
\hline S104 & C44COMP2 & Sludge & NA & NA & 0.1100 & $\mathrm{NA}$ & $8 / 10 / 92$ \\
\hline S104 & Composite & Sludge & NA & $\mathrm{NA}$ & 0.2300 & NA & $4 / 13 / 90$ \\
\hline S107 & 3148 & Liquid & 1.2 & 53.70 & 0.9768 & 2.11 & $9 / 7 / 78$ \\
\hline $\mathrm{S} 107$ & 4251 & Liquid & NA & NA & 0.2623 & $\mathrm{NA}$ & $10 / 16 / 78$ \\
\hline S107 & RAT-S107-1 & Liquid & NA & NA & 0.3100 & $\mathrm{NA}$ & $4 / 27 / 90$ \\
\hline $\mathrm{S} 107$ & RAT-S107-2 & Liquid & 1.4 & 41.65 & 0.6289 & 1.08 & $9 / 22 / 80$ \\
\hline $\mathrm{S} 10^{*}$ & RAT-S107-3 & Liquid & 1.1 & 55.94 & 0.7473 & 1.70 & $9 / 22 / 80$ \\
\hline $\mathrm{S} 109$ & & Salt & NA & NA & 0.0470 & $\mathrm{NA}$ & $1 / 1 / 80$ \\
\hline $\mathrm{S} 110$ & & Liquid & $\mathrm{NA}$ & $\mathrm{NA}$ & 1.2500 & $\mathrm{NA}$ & $1 / 1 / 80$ \\
\hline
\end{tabular}




\begin{tabular}{|c|c|c|c|c|c|c|c|}
\hline Tank & $\begin{array}{c}\text { Sample } \\
\text { ID }\end{array}$ & $\begin{array}{l}\text { Waste } \\
\text { Phase }\end{array}$ & $\begin{array}{l}(\mathrm{g} / \mathrm{mL}) \\
\text { Density }\end{array}$ & $\% \mathrm{H}_{2} \mathrm{O}$ & $\% \mathrm{TOC}$ & $\begin{array}{c}\text { Dry } \\
\% \text { TOC }\end{array}$ & $\begin{array}{l}\text { Ref. } \\
\text { Date }\end{array}$ \\
\hline S111. & $1001-\mathrm{C}$ & Salt & 1.3 & 10.70 & 0.1016 & 0.11 & $8 / 25 / 78$ \\
\hline S111 & $1003 / 1004-C$ & Salt & 1.9 & 17.40 & 1.5400 & 1.86 & $8 / 25 / 78$ \\
\hline S111 & $1009-\mathrm{C}$ & Liquid & 1.5 & 44.60 & 0.4247 & 0.77 & $8 / 25 / 78$ \\
\hline S111 & $1009-\mathrm{C}$ & Salt & 1.4 & 18.10 & 2.3353 & 2.85 & $8 / 25 / 78$ \\
\hline S111 & RAT-S111-1 & Liquid & $\mathrm{NA}$ & $\mathrm{NA}$ & 0.2800 & $\mathrm{NA}$ & $4 / 27 / 90$ \\
\hline S111 & RAT-S111-3 & Liquid & NA & NA & 0.4000 & NA & $8 / 25 / 78$ \\
\hline SX101 & E-00162 & Liquid & NA & NA & 0.2400 & NA & $2 / 7 / 79$ \\
\hline SX101 & $\mathrm{R}-4884$ & Liquid & 1.1 & $\mathrm{NA}$ & 0.0288 & $\mathrm{NA}$ & $4 / 26 / 89$ \\
\hline SX101 & RAT-SX101-1 & Liquid & 1.0 & 96.48 & 0.3838 & 10.90 & $10 / 29 / 80$ \\
\hline SX101 & RAT-SX101-2 & Liquid & 1.0 & 93.84 & 0.5655 & 9.18 & $10 / 29 / 80$ \\
\hline SX102 & & Salt & NA & NA & 0.1980 & $\mathrm{NA}$ & $1 / 1 / 80$ \\
\hline SX102 & $\mathrm{T}-2959$ & Salt & NA & $\mathrm{NA}$ & 0.8167 & NA & $9 / 3 / 80$ \\
\hline SX102 & RAT-SX-102- & Salt & NA & 13.90 & NA & NA & $3 / 18 / 76$ \\
\hline SX103 & & Salt & NA & NA & 0.1980 & $\mathrm{NA}$ & $1 / 1 / 80$ \\
\hline SX104 & RAT-SX104-3B & Liquid & 1.4 & NA & 0.1029 & 0.27 & $8 / 15 / 88$ \\
\hline SX104 & RAT-SX104-3B & Liquid & 1.7 & NA & 0.2570 & $\mathrm{NA}$ & $8 / 15 / 88$ \\
\hline SX104 & RAT-SX104-3B & Liquid & 1.8 & NA & 0.2870 & NA & \\
\hline SX104 & RAT-SX104-3B & Liquid & NA & 61.90 & NA & $\mathrm{NA}$ & $8 / 15 / 88$ \\
\hline SX104 & RAT-SX104-3T & Liquid & 1.4 & NA & 0.2284 & 0.46 & $5 / 14 / 88$ \\
\hline SX104 & RAT-SX104-3T & Liquid & 2.0 & NA & 0.2430 & NA & \\
\hline SX104 & RAT-SX104-3T & Liquid & 1.5 & NA & 0.8990 & NA & \\
\hline SX104 & RAT-SX104-3T & Liquid & NA & 50.80 & NA & NA & $5 / 14 / 88$ \\
\hline SX106 & 5268 & Liquid & NA & NA & 0.0900 & NA & $11 / 13 / 78$ \\
\hline SX106 & 8301 & Liquid & 1.4 & 46.10 & 5.9612 & 11.06 & $4 / 18 / 78$ \\
\hline SX106 & RAT-SX106-2 & Liquid & NA & $\mathrm{NA}$ & 5.0276 & $\mathrm{NA}$ & $2 / 28 / 77$ \\
\hline SX106 & RAT-SX106-2 & Liquid & $\mathrm{NA}$ & $\mathrm{NA}$ & 5.6297 & $\mathrm{NA}$ & $2 / 28 / 77$ \\
\hline SX106 & RAT-SX106-2 & Liquid & NA & 46.00 & NA & $\mathrm{NA}$ & $2 / 28 / 77$ \\
\hline SX106 & RAT-SX106-2 & Salt & NA & 39.00 & NA & $\mathrm{NA}$ & $2 / 28 / 77$ \\
\hline SX106 & RAT-SX106- & Sludge & NA & 37.00 & NA & $\mathrm{NA}$ & $2 / 28 / 77$ \\
\hline SX107 & RAT-SX107-1 & Liquid & 1.2 & 69.32 & 0.3871 & 1.26 & $9 / 5 / 79$ \\
\hline SX107 & 1345 & Salt & NA & 10.00 & NA & $\mathrm{NA}$ & $1 / 29 / 77$ \\
\hline $\mathrm{T} 101$ & RAT-T101-2 & Liquid & NA & NA & 0.0500 & NA & $4 / 27 / 90$ \\
\hline T104 & & Sludge & NA & NA & 0.0100 & $\mathrm{NA}$ & $9 / 1 / 92$ \\
\hline T104 & 175COMP1 & Sludge & NA & NA & 0.0760 & $\mathrm{NA}$ & $1 / 1 / 93$ \\
\hline T104 & 176COMP1 & Sludge & NA & NA & 0.0550 & NA & $1 / 3 / 93$ \\
\hline T104 & 179COMP2 & Sludge & NA & NA & 0.0550 & NA & $1 / 5 / 93$ \\
\hline T104 & 180COMP2 & Sludge & NA & NA & 0.0550 & NA & $1 / 7 / 93$ \\
\hline T104 & 204COMP & Liquid & 1.1 & NA & 0.0492 & $\mathrm{NA}$ & $1 / 13 / 93$ \\
\hline $\mathrm{T} 104$ & RAT-T104-2 & Sludge & 1.3 & NA & 0.2900 & 0.77 & $9 / 18 / 80$ \\
\hline T104 & RAT-T104-2 & Sludge & NA & 62.20 & NA & $\mathrm{NA}$ & $9 / 18 / 80$ \\
\hline
\end{tabular}




\begin{tabular}{|c|c|c|c|c|c|c|c|}
\hline Tank & $\begin{array}{l}\text { Sample } \\
\text { ID }\end{array}$ & $\begin{array}{l}\text { Waste } \\
\text { Phase }\end{array}$ & $\begin{array}{l}(\mathrm{g} / \mathrm{mL}) \\
\text { Density }\end{array}$ & $\% \mathrm{H}_{2} \mathrm{O}$ & $\% \mathrm{TOC}$ & $\begin{array}{c}\text { Dry } \\
\% \text { TOC }\end{array}$ & $\begin{array}{l}\text { Ref. } \\
\text { Date }\end{array}$ \\
\hline$\overline{\mathrm{T} 104}$ & RAT-T104-2 & Sludge & $\mathrm{NA}$ & 62.20 & $\mathrm{NA}$ & $\mathrm{NA}$ & $9 / 18 / 80$ \\
\hline T107 & C50COMP & Liquid & NA & 95.10 & NA & NA & $8 / 1 / 94$ \\
\hline T107 & C50S1R & Sludge & NA & NA & 0.0505 & 0.05 & $8 / 1 / 94$ \\
\hline T107 & C50S1R & Sludge & NA & 5.76 & NA & NA & $8 / 1 / 94$ \\
\hline T107 & C50S1R & Sludge & NA & 26.20 & NA & NA & $8 / 1 / 94$ \\
\hline $\mathrm{T} 107$ & C50S2 & Sludge & 1.7 & NA & 0.0655 & 0.08 & $8 / 1 / 94$ \\
\hline T107 & $\mathrm{C} 50 \mathrm{~S} 2$ & Sludge & NA & 18.00 & $\mathrm{NA}$ & NA & $8 / 1 / 94$ \\
\hline $\mathrm{T} 107$ & $\mathrm{C} 50 \mathrm{~S} 2$ & Sludge & $\mathrm{NA}$ & 43.00 & NA & $\mathrm{NA}$ & $8 / 1 / 94$ \\
\hline T107 & C50S3 & Sludge & NA & 41.50 & NA & NA & $8 / 1 / 94$ \\
\hline T107 & C51COMP & Sludge & 1.5 & NA & 0.0400 & 0.08 & $8 / 1 / 94$ \\
\hline $\mathrm{T} 107$ & C51COMP & Sludge & $\mathrm{NA}$ & $\mathrm{NA}$ & 0.1440 & 0.30 & $8 / 1 / 94$ \\
\hline $\mathrm{T} 107$ & C51COMP & Liquid & 1.2 & 73.70 & 0.1060 & 0.40 & $8 / 1 / 94$ \\
\hline T107 & C51COMP & Sludge & $\mathrm{NA}$ & 49.50 & NA & $\mathrm{NA}$ & $8 / 1 / 94$ \\
\hline T107 & C51COMP & Sludge & $\mathrm{NA}$ & 51.90 & $\mathrm{NA}$ & $\mathrm{NA}$ & $8 / 1 / 94$ \\
\hline T107 & $\mathrm{C} 51 \mathrm{~S} 2$ & Sludge & $\mathrm{NA}$ & 95.60 & 0.1100 & 2.50 & $8 / 1 / 94$ \\
\hline T107 & C51S3L & Sludge & 1.7 & 55.10 & 0.0905 & 0.20 & $8 / 1 / 94$ \\
\hline $\mathrm{T} 107$ & C 51 S3U & Sludge & 1.5 & 60.20 & 0.1270 & 0.32 & $8 / 1 / 94$ \\
\hline T107 & C51S4L & Sludge & 1.5 & 55.00 & 0.0270 & 0.06 & $8 / 1 / 94$ \\
\hline T107 & C51S4U & Sludge & 1.5 & 52.90 & 0.0265 & 0.06 & $8 / 1 / 94$ \\
\hline T107 & C52COMP & Sludge & $\mathrm{NA}$ & NA & 0.0320 & 0.06 & $8 / 1 / 94$ \\
\hline $\mathrm{T} 107$ & C52COMP & Liquid & 1.1 & 82.90 & 0.0354 & 0.21 & $8 / 1 / 94$ \\
\hline T107 & C52COMP & Sludge & 1.2 & NA & 0.1690 & $\mathrm{NA}$ & $8 / 1 / 94$ \\
\hline T107 & C52COMP & Sludge & NA & 47.80 & NA & $\mathrm{NA}$ & $8 / 1 / 94$ \\
\hline T107 & $\mathrm{C} 52 \mathrm{~S} 1$ & Sludge & NA & 75.30 & 0.1950 & 0.79 & $8 / 1 / 94$ \\
\hline $\mathrm{T} 107$ & $\mathrm{C} 52 \mathrm{~S} 2$ & Sludge & 1.6 & 16.70 & 0.0970 & 0.12 & $8 / 1 / 94$ \\
\hline $\mathrm{T} 107$ & C.52S3L & Sludge & 1.5 & 51.40 & 0.0265 & 0.05 & $8 / 1 / 94$ \\
\hline $\mathrm{T} 107$ & $\mathrm{C} 52 \mathrm{~S} 3 \mathrm{U}$ & Sludge & 1.5 & 48.50 & 0.0685 & 0.13 & $8 / 1 / 94$ \\
\hline T107 & $\mathrm{C} 52 \mathrm{~S} 4$ & Sludge & NA & 53.50 & NA. & $\mathrm{NA}$ & $8 / 1 / 94$ \\
\hline $\mathrm{T} 107$ & $\mathrm{R}-3872$ & Liquid & $\mathrm{NA}$ & NA & 0.0700 & NA & $3 / 5 / 85$ \\
\hline $\mathrm{T} 107$ & RAT-T107-1 & Liquid & $\mathrm{NA}$ & $\mathrm{NA}$ & 0.0720 & $\mathrm{NA}$ & $8 / 1 / 89$ \\
\hline $\mathrm{T} 111$ & C31COMP1 & Sludge & $\mathrm{NA}$ & $\mathrm{NA}$ & 0.3300 & NA & $12 / 1 / 91$ \\
\hline $\mathrm{T} 111$ & C31COMP1 & Sludge & NA & $\mathrm{NA}$ & 0.3680 & NA & $12 / 2 / 91$ \\
\hline $\mathrm{T} 111$ & C31COMP2 & Sludge & NA & NA & 0.3850 & NA & $12 / 3 / 91$ \\
\hline $\mathrm{T} 111$ & C31COMP2 & Sludge & $\mathrm{NA}$ & $\mathrm{NA}$ & 0.4120 & $\mathrm{NA}$ & $12 / 4 / 91$ \\
\hline $\mathrm{T} 111$ & C33COMP1 & Sludge & $\mathrm{NA}$ & NA & 0.2000 & $\mathrm{NA}$ & $12 / 5 / 91$ \\
\hline $\mathrm{T} 111$ & C33COMP1 & Sludge & NA & NA & 0.2000 & NA & $12 / 6 / 91$ \\
\hline $\mathrm{T} 111$ & C33COMP2 & Sludge & $\mathrm{NA}$ & NA & 0.3000 & NA & $12 / 7 / 91$ \\
\hline $\mathrm{T} 111$ & C33COMP2 & Sludge & NA & NA & 0.3000 & $\mathrm{NA}$ & $12 / 8 / 91$ \\
\hline $\mathrm{T} 112$ & RAT-T112-1 & Liquid & NA & NA & 0.1900 & NA & $10 / 27 / 87$ \\
\hline $\mathrm{T} 112$ & $\mathrm{~T}-5821$ & Liquid & NA & 87.32 & NA & NA & $8 / 14 / 74$ \\
\hline
\end{tabular}




\begin{tabular}{|c|c|c|c|c|c|c|c|}
\hline Tank & $\begin{array}{c}\text { Sample } \\
\text { ID }\end{array}$ & $\begin{array}{l}\text { Waste } \\
\text { Phase }\end{array}$ & $\begin{array}{l}(\mathrm{g} / \mathrm{mL}) \\
\text { Density }\end{array}$ & $\% \mathrm{H}_{2} \mathrm{O}$ & $\% \mathrm{TOC}$ & $\begin{array}{c}\text { Dry } \\
\% \text { TOC }\end{array}$ & $\begin{array}{l}\text { Ref. } \\
\text { Date }\end{array}$ \\
\hline T204 & 1914 & Sludge & $\mathrm{NA}$ & 73.00 & 0.6735 & $\mathrm{NA}$ & $12 / 4 / 78$ \\
\hline TX102 & RAT-TX102-1 & Salt & NA & NA & 0.1909 & $\mathrm{NA}$ & $2 / 3 / 81$ \\
\hline TX102 & RAT-TX102-1 & Sludge & NA & 44.51 & NA & $\mathrm{NA}$ & $2 / 3 / 81$ \\
\hline TX102 & RAT-TX102-1A & Liquid & NA & $\mathrm{NA}$ & 0.3850 & NA & $2 / 3 / 81$ \\
\hline TX102 & RAT-TX102-2 & Liquid & NA & NA & 0.1639 & NA & $2 / 3 / 81$ \\
\hline TX103 & $\mathrm{T}-1465$ & Liquid & NA & $\mathrm{NA}$ & 0.2720 & NA & $9 / 21 / 79$ \\
\hline TX103 & $\mathrm{T}-1467$ & Liquid & $\mathrm{NA}$ & $\mathrm{NA}$ & 0.2680 & $\mathrm{NA}$ & $9 / 21 / 79$ \\
\hline TX103 & $\mathrm{T}-1470$ & Liquid & $\mathrm{NA}$ & NA & 0.2768 & $\mathrm{NA}$ & $9 / 21 / 79$ \\
\hline TX103 & $\mathrm{T}-2955$ & Liquid & NA & 51.03 & NA & NA & \\
\hline TX105 & RAT-TX105-1 & Liquid & NA & $\mathrm{NA}$ & 0.8724 & NA & $2 / 3 / 81$ \\
\hline TX106 & RAT-TX106-1 & Liquid & NA & NA & 0.4281 & NA & $2 / 3 / 81$ \\
\hline TX108 & RAT-TX108-1 & Liquid & NA & NA & 0.5931 & NA & $2 / 5 / 81$ \\
\hline TX108 & $\mathrm{T}-1989$ & Liquid & $\mathrm{NA}$ & 56.07 & NA & $\mathrm{NA}$ & $2 / 2 / 76$ \\
\hline TX109 & RAT-TX109-2 & Liquid & NA & NA & 0.6718 & $\mathrm{NA}$ & $2 / 3 / 81$ \\
\hline TX110 & RAT-TX110-1 & Liquid & $\mathrm{NA}$ & NA & 0.6068 & $\mathrm{NA}$ & $8 / 4 / 79$ \\
\hline TX110 & RAT-TX110-2 & Liquid & 1.4 & 45.80 & 0.2961 & 0.55 & $2 / 10 / 81$ \\
\hline TX110 & RAT-TX110-4 & Liquid & NA & $\mathrm{NA}$ & 0.2961 & $\mathrm{NA}$ & $2 / 3 / 81$ \\
\hline TX111 & RAT-TX111-1 & Liquid & $\mathrm{NA}$ & $\mathrm{NA}$ & 0.4563 & NA & $2 / 3 / 81$ \\
\hline TX112 & RAT-TX112-1 & Liquid & $\mathrm{NA}$ & $\mathrm{NA}$ & 0.2690 & $\mathrm{NA}$ & $2 / 3 / 81$ \\
\hline TX114 & RAT-TX114-1 & Liquid & $\mathrm{NA}$ & NA & 0.1986 & NA & $2 / 3 / 81$ \\
\hline TX115 & RAT-TX115-1 & Liquid & NA & NA & 0.0252 & NA & $2 / 3 / 81$ \\
\hline TX115 & RAT-TX116-1 & Liquid & NA & $\mathrm{NA}$ & 0.0712 & NA & $2 / 3 / 81$ \\
\hline TX116 & & Liquid & $\mathrm{NA}$ & NA & 0.0800 & NA & $2 / 3 / 81$ \\
\hline TX118 & & Liquid & NA & NA & 3.2200 & NA & $1 / 1 / 80$ \\
\hline TX118 & 8385 & Liquid & $\mathrm{NA}$ & NA & 0.0174 & NA & $3 / 21 / 79$ \\
\hline TX118 & RAT-TX118-1 & Liquid & $\mathrm{NA}$ & $\mathrm{NA}$ & 0.1566 & $\mathrm{NA}$ & $1 / 28 / 80$ \\
\hline TX118 & RAT-TX118-3 & Liquid & NA & NA & 0.1403 & NA & $1 / 28 / 80$ \\
\hline TX118 & RAT-TX118-4 & Liquid & NA & $\mathrm{NA}$ & 0.1000 & $\mathrm{NA}$ & $10 / 16 / 81$ \\
\hline TX118 & RAT-TX118-5 & Liquid & $\mathrm{NA}$ & NA & 0.1100 & $\mathrm{NA}$ & $10 / 16 / 81$ \\
\hline TX118 & RAT-TX118-6 & Salt & NA & NA & 1.0600 & $\mathrm{NA}$ & $10 / 16 / 81$ \\
\hline TY101 & $51 \mathrm{XC} 00 \mathrm{XX} / \mathrm{R} 6788$ & Sludge & 1.6 & 43.50 & 0.0020 & 0.00 & $9 / 11 / 85$ \\
\hline TY101 & $51 X C 00 X X / R 6793$ & Sludge & 1.6 & 43.50 & 0.0020 & 0.00 & $9 / 11 / 85$ \\
\hline TY101 & $\mathrm{T}-3533$ & Liquid & $\mathrm{NA}$ & NA & 0.0184 & NA & $12 / 6 / 82^{\circ}$ \\
\hline TY102 & $41 \mathrm{XCOOOO}$ & Sludge & NA & NA & 0.0327 & NA & $9 / 9 / 85$ \\
\hline TY102 & RAT-TY102-1 & Salt & NA & 58.00 & 0.2360 & NA & $2 / 1 / 80$ \\
\hline TY103 & $31 \mathrm{XCOOOO}$ & Sludge & NA & $\mathrm{NA}$ & 0.0715 & NA & $8 / 21 / 85$ \\
\hline TY103 & $32 \times C O O O O$ & Sludge & NA & NA & 0.1490 & NA & $8 / 21 / 85$ \\
\hline TY103 & $33 \mathrm{XCOOO}$ & Liquid & NA & NA & 0.1565 & $\mathrm{NA}$ & $8 / 21 / 85$ \\
\hline TY103 & C31XCCOMP1 & Sludge & NA & NA & 0.0715 & NA & $9 / 15 / 85$ \\
\hline TY103 & C31XDCOMP1 & Sludge & NA & NA & 0.1490 & $\mathrm{NA}$ & $9 / 15 / 85$ \\
\hline
\end{tabular}




\begin{tabular}{|c|c|c|c|c|c|c|c|}
\hline Tank & $\begin{array}{c}\text { Sample } \\
\text { ID }\end{array}$ & $\begin{array}{l}\text { Waste } \\
\text { Phase }\end{array}$ & $\begin{array}{l}(\mathrm{g} / \mathrm{mL}) \\
\text { Density }\end{array}$ & $\% \mathrm{H}_{2} \mathrm{O}$ & $\% \mathrm{TOC}$ & $\begin{array}{c}\text { Dry } \\
\% \text { TOC }\end{array}$ & $\begin{array}{l}\text { Ref. } \\
\text { Date }\end{array}$ \\
\hline TY103 & RAT-TY103-1 & Sludge & 1.5 & 52.67 & 0.1100 & 0.23 & $9 / 18 / 80$ \\
\hline TY103 & RAT-TY103-2 & Sludge & NA & 53.00 & 0.0040 & 0.01 & $2 / 1 / 80$ \\
\hline TY104 & 211D0000 & Liquid & NA & NA & 0.1603 & NA & $8 / 6 / 85$ \\
\hline TY104 & $232 \mathrm{DOOOOO}$ & Liquid & $\mathrm{NA}$ & $\mathrm{NA}$ & 0.1694 & NA & $8 / 12 / 85$ \\
\hline TY104 & $232 S 0000$ & Sludge & $\mathrm{NA}$ & $\mathrm{NA}$ & 0.2100 & $\mathrm{NA}$ & $8 / 6 / 85$ \\
\hline TY104 & 241D0000 & Liquid & NA & NA & 0.2042 & $\mathrm{NA}$ & $8 / 6 / 85$ \\
\hline TY104 & $241 \mathrm{~S} 0000$ & Sludge & NA & $\mathrm{NA}$ & 0.2780 & $\mathrm{NA}$ & $8 / 6 / 85$ \\
\hline TY104 & $251 \mathrm{SO000}$ & Sludge & $\mathrm{NA}$ & $\mathrm{NA}$ & 0.1950 & $\mathrm{NA}$ & $8 / 14 / 85$ \\
\hline TY104 & 26150000 & Sludge & $\mathrm{NA}$ & $\mathrm{NA}$ & 0.0907 & $\mathrm{NA}$ & $8 / 16 / 85$ \\
\hline TY104 & C241SCOMP1 & Sludge & NA & NA & 0.2780 & NA & $9 / 15 / 85$ \\
\hline TY104 & C251SCOMP1 & Sludge & $\mathrm{NA}$ & NA & 0.1950 & NA & $9 / 15 / 85$ \\
\hline TY104 & C261SCOMP1 & Sludge & NA & $\mathrm{NA}$ & 0.0907 & NA & $9 / 15 / 85$ \\
\hline TY104 & C32XSCOMP1 & Sludge & $\mathrm{NA}$ & NA & 0.2100 & $\mathrm{NA}$ & $9 / 15 / 85$ \\
\hline TY104 & RAT-TY104-1 & Sludge & $\mathrm{NA}$ & $\mathrm{NA}$ & 0.4000 & NA & $12 / 20 / 79$ \\
\hline TY104 & RAT-TY104-2 & Sludge & 1.4 & $\mathrm{NA}$ & 0.0600 & 0.13 & $9 / 18 / 80$ \\
\hline TY104 & RAT-TY104-2 & Sludge & 1.4 & $\mathrm{NA}$ & 1.4700 & 3.11 & $9 / 18 / 80$ \\
\hline TY104 & RAT-TY104-2 & Sludge & 1.4 & NA & 2.8000 & 5.92 & $9 / 18 / 80$ \\
\hline TY104 & RAT-TY104-2 & Sludge & NA & 52.73 & NA & NA & $9 / 18 / 80$ \\
\hline TY104 & RAT-TY104-2 & Sludge & $\mathrm{NA}$ & 52.73 & NA & $\mathrm{NA}$ & $9 / 18 / 80$ \\
\hline TY104 & RAT-TY104-2 & Sludge & $\mathrm{NA}$ & 52.73 & $\mathrm{NA}$ & $\mathrm{NA}$ & $9 / 18 / 80$ \\
\hline TY105 & $61 \times \mathrm{COOOO}$ & Sludge & $\mathrm{NA}$ & 39.40 & 0.0805 & $\mathrm{NA}$ & $9 / 13 / 85$ \\
\hline TY106 & $111 \mathrm{COOOO}$ & Sludge & NA & NA & 0.2480 & NA & $7 / 31 / 85$ \\
\hline TY106 & $111 \mathrm{CXCOMP} 1$ & Sludge & 1.3 & $\mathrm{NA}$ & 0.0780 & 0.13 & $9 / 14 / 85$ \\
\hline TY106 & 111CXCOMP1 & Sludge & 1.3 & NA & 0.1700 & 0.28 & $9 / 14 / 85$ \\
\hline TY106 & 111CXCOMP1 & Sludge & $\mathrm{NA}$ & 39.20 & $\mathrm{NA}$ & $\mathrm{NA}$ & $9 / 14 / 85$ \\
\hline TY106 & 111CXCOMP1 & Sludge & $\mathrm{NA}$ & 39.20 & $\mathrm{NA}$ & $\mathrm{NA}$ & $9 / 14 / 85$ \\
\hline TY106 & $161 \mathrm{COOOO}$ & Sludge & NA & NA & 0.2090 & NA & $9 / 26 / 85$ \\
\hline TY106 & 161CXCOMP1 & Sludge & $\mathrm{NA}$ & NA & 0.2090 & NA & $9 / 15 / 85$ \\
\hline TY106 & RAT-TY106-2 & Sludge & 1.9 & 35.50 & 0.0920 & 0.14 & $9 / 18 / 80$ \\
\hline U103 & & Sludge & $\mathrm{NA}$ & 8.70 & NA & $\mathrm{NA}$ & $12 / 4 / 78$ \\
\hline U103 & 3064 & Sludge & 1.4 & NA & 0.6863 & 0.75 & $12 / 4 / 78$ \\
\hline U103 & 8793 & Salt & $\mathrm{NA}$ & NA & 3.3800 & $\mathrm{NA}$ & $8 / 15 / 77$ \\
\hline U103 & RAT-U103-1 & Liquid & $\mathrm{NA}$ & 63.20 & NA & $\mathrm{NA}$ & $4 / 16 / 76$ \\
\hline U105 & RAT-U105-3 & Salt & 1.6 & 20.80 & 2.8000 & 3.54 & $12 / 4 / 78$ \\
\hline U106 & & Liquid & 1.3 & 61.91 & 9.9600 & 26.15 & $1 / 1 / 80$ \\
\hline $\mathrm{U} 110$ & $\mathrm{C} 12 \mathrm{~S} 2$ & Sludge & 1.8 & $\mathrm{NA}$ & 0.0794 & 0.13 & $9 / 1 / 93$ \\
\hline U110 & $\mathrm{C} 12 \mathrm{~S} 2$ & Sludge & 1.8 & NA & 0.0779 & 0.14 & $9 / 1 / 93$ \\
\hline U110 & $\mathrm{C} 12 \mathrm{~S} 2$ & Sludge & $\mathrm{NA}$ & 38.19 & NA & $\mathrm{NA}$ & $9 / 1 / 93$ \\
\hline U110 & $\mathrm{C} 12 \mathrm{~S} 2$ & Sludge & NA & 43.60 & NA & $\mathrm{NA}$ & $9 / 1 / 93$ \\
\hline U110 & $\mathrm{C} 12 \mathrm{~S} 3$ & Sludge & 1.0 & NA & 0.0713 & 0.12 & $9 / 1 / 93$ \\
\hline
\end{tabular}




\begin{tabular}{|c|c|c|c|c|c|c|c|}
\hline Tank & $\begin{array}{c}\text { Sample } \\
\text { ID }\end{array}$ & $\begin{array}{l}\text { Waste } \\
\text { Phase }\end{array}$ & $\begin{array}{l}(\mathrm{g} / \mathrm{mL}) \\
\text { Density }\end{array}$ & $\% \mathrm{H}_{2} \mathrm{O}$ & $\% \mathrm{TOC}$ & $\begin{array}{c}\text { Dry } \\
\% \text { TOC }\end{array}$ & $\begin{array}{l}\text { Ref. } \\
\text { Date }\end{array}$ \\
\hline U110 & C12S3 & Sludge & 1.0 & $\mathrm{NA}$ & 0.0734 & 0.12 & $9 / 1 / 93$ \\
\hline U110 & $\mathrm{C} 12 \mathrm{~S} 3$ & Sludge & $\mathrm{NA}$ & 39.06 & NA & $\mathrm{NA}$ & $9 / 1 / 93$ \\
\hline U110 & $\mathrm{C} 12 \mathrm{~S} 3$ & Sludge & NA & 39.04 & NA & NA & $9 / 1 / 93$ \\
\hline $\mathrm{U} 110$ & C12S4 & Sludge & 1.5 & $\mathrm{NA}$ & 0.0715 & 0.13 & $9 / 1 / 93$ \\
\hline $\mathrm{U} 110$ & $\mathrm{C} 12 \mathrm{~S} 4$ & Sludge & 1.5 & NA & 0.0898 & 0.16 & $9 / 1 / 93$ \\
\hline U110 & $\mathrm{C} 12 \mathrm{~S} 4$ & Sludge & $\mathrm{NA}$ & 44.36 & NA & $\mathrm{NA}$ & $9 / 1 / 93$ \\
\hline $\mathrm{U} 110$ & $\mathrm{C} 12 \mathrm{~S} 4$ & Sludge & $\mathrm{NA}$ & 44.10 & NA & NA & $9 / 1 / 93$ \\
\hline U110 & $\mathrm{C} 13 \mathrm{~S} 3$ & Sludge & 1.1 & NA & 0.0409 & 0.07 & $9 / 1 / 93$ \\
\hline U110 & C13S3 & Sludge & 1.1 & NA & 0.0708 & 0.12 & $9 / 1 / 93$ \\
\hline U110 & C13S3 & Sludge & NA & 43.18 & $\mathrm{NA}$ & NA & $9 / 1 / 93$ \\
\hline U110 & C13S3 & Sludge & $\mathrm{NA}$ & 42.98 & NA & NA & $9 / 1 / 93$ \\
\hline $\mathrm{U} 110$ & $\mathrm{C} 13 \mathrm{~S} 4$ & Sludge & 1.5 & NA & 0.0785 & 0.15 & $9 / 1 / 93$ \\
\hline U110 & $\mathrm{C} 13 \mathrm{~S} 4$ & Sludge & 1.5 & $\mathrm{NA}$ & 0.0896 & 0.16 & $9 / 1 / 93$ \\
\hline U110 & C13S4 & Sludge & $\mathrm{NA}$ & 46.78 & NA & $\mathrm{NA}$ & $9 / 1 / 93$ \\
\hline $\mathrm{U} 110$ & $\mathrm{C} 13 \mathrm{~S} 4$ & Sludge & $\mathrm{NA}$ & 44.68 & NA & NA & $9 / 1 / 93$ \\
\hline U110 & $\mathrm{C} 14 \mathrm{~S} 1$ & Sludge & 1.5 & $\mathrm{NA}$ & 0.0361 & 0.04 & $9 / 1 / 93$ \\
\hline U110 & C14S1 & Sludge & 1.5 & $\mathrm{NA}$ & 0.0494 & 0.05 & $9 / 1 / 93$ \\
\hline U110 & C14S1 & Sludge & NA & 4.75 & . NA & NA & $9 / 1 / 93$ \\
\hline U110 & C14S1 & Sludge & $\mathrm{NA}$ & 5.59 & $\mathrm{NA}$ & $\mathrm{NA}$ & $9 / 1 / 93$ \\
\hline U110 & $\mathrm{C} 14 \mathrm{~S} 2$ & Sludge & 1.4 & $\mathrm{NA}$ & 0.0599 & 0.08 & $9 / 1 / 93$ \\
\hline U110 & $\mathrm{C} 14 \mathrm{~S} 2$ & Sludge & 1.4 & $\mathrm{NA}$ & 0.0653 & 0.09 & $9 / 1 / 93$ \\
\hline U110 & $\mathrm{C} 14 \mathrm{~S} 2$ & Sludge & NA & 29.10 . & NA & NA & $9 / 1 / 93$ \\
\hline U110 & $\mathrm{C} 14 \mathrm{~S} 2$ & Sludge & $\mathrm{NA}$ & 26.90 & $\mathrm{NA}$ & $\mathrm{NA}$ & $9 / 1 / 93$ \\
\hline U110 & $\mathrm{C} 14 \mathrm{~S} 3$ & Sludge & 1.4 & NA & 0.0352 & 0.06 & $9 / 1 / 93$ \\
\hline $\mathrm{U} 110$ & $\mathrm{C} 14 \mathrm{~S} 3$ & Sludge & 1.4 & $\mathrm{NA}$ & 0.0540 & 0.09 & $9 / 1 / 93$ \\
\hline $\mathrm{U} 110$ & $\mathrm{C} 14 \mathrm{~S} 3$ & Sludge & $\mathrm{NA}$ & 42.51 & NA & NA & $9 / 1 / 93$ \\
\hline $\mathrm{U} 110$ & $\mathrm{C} 14 \mathrm{~S} 3$ & Sludge & NA & 42.64 & NA & $\mathrm{NA}$ & $9 / 1 / 93$ \\
\hline U110 & C14S4 & Sludge & 1.6 & NA & 0.1100 & 0.18 & $9 / 1 / 93$ \\
\hline U110 & C14S4 & Sludge & 1.6 & NA & 0.1110 & 0.18 & $9 / 1 / 93$ \\
\hline $\mathrm{U} 110$ & $\mathrm{C} 14 \mathrm{~S} 4$ & Sludge & $\mathrm{NA}$ & 37.30 & NA & NA & $9 / 1 / 93$ \\
\hline U110 & $\mathrm{C} 14 \mathrm{~S} 4$ & Sludge & NA & 37.27 & NA & $\mathrm{NA}$ & $9 / 1 / 93$ \\
\hline U110 & $\mathrm{C} 15 \mathrm{~S} 2$ & Sludge & 1.3 & NA & 0.6430 & 1.08 & $9 / 1 / 93$ \\
\hline $\mathrm{U} 110$ & $\mathrm{C} 15 \mathrm{~S} 2$ & Sludge & 1.3 & NA & 0.6750 & 1.17 & $9 / 1 / 93$ \\
\hline $\mathrm{U} 110$ & $\mathrm{C} 15 \mathrm{~S} 2$ & Sludge & NA & 40.60 & NA & $\mathrm{NA}$ & $9 / 1 / 93$ \\
\hline U110 & $\mathrm{C} 15 \mathrm{~S} 2$ & Sludge & NA & 42.50 & NA & NA & $9 / 1 / 93$ \\
\hline $\mathrm{U} 110$ & C15S3 & Sludge & $\mathrm{NA}$ & 41.60 & $\mathrm{NA}$ & NA & $9 / 1 / 93$ \\
\hline U110 & C15S3 & Sludge & NA & 44.30 & NA & NA & $9 / 1 / 93$ \\
\hline $\mathrm{U} 110$ & C15S4 & Sludge & NA & 39.90 & NA & $\mathrm{NA}$ & $9 / 1 / 93$ \\
\hline U110 & $\mathrm{C} 15 \mathrm{~S} 4$ & Sludge & NA & 42.30 & NA & NA & $9 / 1 / 93$ \\
\hline $\mathrm{U} 110$ & C5S3 & Sludge & 1.0 & $\mathrm{NA}$ & 0.0530 & 0.09 & $9 / 1 / 93$ \\
\hline
\end{tabular}




\begin{tabular}{|c|c|c|c|c|c|c|c|}
\hline Tank & $\begin{array}{l}\text { Sample } \\
\text { ID }\end{array}$ & $\begin{array}{l}\text { Waste } \\
\text { Phase }\end{array}$ & $\begin{array}{l}(\mathrm{g} / \mathrm{mL}) \\
\text { Density }\end{array}$ & $\% \mathrm{H}_{2} \mathrm{O}$ & $\% \mathrm{TOC}$ & $\begin{array}{c}\text { Dry } \\
\% \text { TOC }\end{array}$ & $\begin{array}{l}\text { Ref. } \\
\text { Date }\end{array}$ \\
\hline U110 & $\mathrm{C} 5 \mathrm{~S} 3$ & Sludge & 1.0 & NA & 0.0554 & 0.09 & $9 / 1 / 93$ \\
\hline U110 & $\mathrm{C} 5 \mathrm{~S} 3$ & Sludge & $\mathrm{NA}$ & 39.20 & $\mathrm{NA}$ & $\mathrm{NA}$ & $9 / 1 / 93$ \\
\hline U110 & C5S3 & Sludge & NA & 39.06 & NA & $\mathrm{NA}$ & $9 / 1 / 93$ \\
\hline U110 & C5S4 & Sludge & NA & NA & 0.0859 & 0.14 & $9 / 1 / 93$ \\
\hline U110 & $\mathrm{C} 5 \mathrm{~S} 4$ & Sludge & NA & NA & 0.1100 & 0.18 & $9 / 1 / 93$ \\
\hline $\mathrm{U} 110$ & $\mathrm{C} 5 \mathrm{~S} 4$ & Sludge & $\mathrm{NA}$ & 38.80 & NA & NA & $9 / 1 / 93$ \\
\hline U110 & $\mathrm{C} 5 \mathrm{~S} 4$ & Sludge & NA & 39.10 & NA & $\mathrm{NA}$ & $9 / 1 / 93$ \\
\hline U110 & $\mathrm{C} 6 \mathrm{~S} 2$ & Sludge & $\mathrm{NA}$ & 37.60 & $\mathrm{NA}$ & $\mathrm{NA}$ & $9 / 1 / 93$ \\
\hline $\mathrm{U} 110$ & $\mathrm{C} 6 \mathrm{~S} 2$ & Sludge & $\mathrm{NA}$ & 39.50 & NA & NA & $9 / 1 / 93$ \\
\hline U110 & $\mathrm{C} 6 \mathrm{~S} 3$ & Sludge & NA & 44.40 & $\mathrm{NA}$ & NA & $9 / 1 / 93$ \\
\hline U110 & $\mathrm{C} 6 \mathrm{~S} 3$ & Sludge & NA & 44.60 & $\mathrm{NA}$ & NA & $9 / 1 / 93$ \\
\hline U110 & $\mathrm{C} 6 \mathrm{~S} 4$ & Sludge & 1.8 & NA & 0.0693 & 0.11 & $9 / 1 / 93$ \\
\hline U110 & $\mathrm{C} 6 \mathrm{~S} 4$ & Sludge & 1.8 & $\mathrm{NA}$ & 0.0726 & 0.12 & $9 / 1 / 93$ \\
\hline U110 & $\mathrm{C} 6 \mathrm{~S} 4$ & Sludge & $\mathrm{NA}$ & 37.30 & NA & NA & $9 / 1 / 93$ \\
\hline U110 & $\mathrm{C} 6 \mathrm{~S} 4$ & Sludge & NA & 38.50 & NA & NA & $9 / 1 / 93$ \\
\hline U110 & C7S1 & Sludge & 1.8 & $\mathrm{NA}$ & 0.0605 & 0.06 & $9 / 1 / 93$ \\
\hline U110 & C7S1 & Sludge & 1.8 & $\mathrm{NA}$ & 0.0740 & 0.08 & $9 / 1 / 93$ \\
\hline U110 & C.S1 & Sludge & $\mathrm{NA}$ & 3.08 & NA & NA & $9 / 1 / 93$ \\
\hline U110 & C7S1 & Sludge & NA & 4.16 & NA & NA & $9 / 1 / 93$ \\
\hline U110 & $\mathrm{C} 7 \mathrm{~S} 2$ & Sludge & 1.5 & NA & 0.1410 & 0.22 & $9 / 1 / 93$ \\
\hline U110 & $\mathrm{C} 7 \mathrm{~S} 2$ & Sludge & 1.5 & $\mathrm{NA}$ & 0.1610 & 0.25 & $9 / 1 / 93$ \\
\hline U110 & $\mathrm{C} 7 \mathrm{~S} 2$ & Sludge & $\mathrm{NA}$ & 37.30 & NA & NA & $9 / 1 / 93$ \\
\hline U110 & $\mathrm{C} 7 \mathrm{~S} 2$ & Sludge & $\mathrm{NA}$ & 34.50 & $\mathrm{NA}$ & $\mathrm{NA}$ & $9 / 1 / 93$ \\
\hline U110 & $\mathrm{C} 7 \mathrm{~S} 3$ & Sludge & $\mathrm{NA}$ & 47.20 & NA & NA & $9 / 1 / 93$ \\
\hline $\mathrm{U} 110$ & C7S3 & Sludge & NA & 47.70 & NA & NA & $9 / 1 / 93$ \\
\hline U110 & $\mathrm{C} 7 \mathrm{~S} 4$ & Sludge & $\mathrm{NA}$ & 35.40 & $\mathrm{NA}$ & $\mathrm{NA}$ & $9 / 1 / 93$ \\
\hline U110 & $\mathrm{C} 7 \mathrm{~S} 4$ & Sludge & $\mathrm{NA}$ & 39.40 & $\mathrm{NA}$ & NA & $9 / 1 / 93$ \\
\hline U110 & C8S1 & Sludge & $\mathrm{NA}$ & $\mathrm{NA}$ & 0.0828 & 0.09 & $9 / 1 / 93$ \\
\hline U110 & $\mathrm{C} 8 \mathrm{~S} 1$ & Sludge & NA & NA & 0.0878 & 0.10 & $9 / 1 / 93$ \\
\hline U110 & C8S1 & Sludge & NA & 8.04 & NA & NA & $9 / 1 / 93$ \\
\hline U110 & C8S1 & Sludge & NA & 8.73 & NA & $\mathrm{NA}$ & $9 / 1 / 93$ \\
\hline U111 & & Liquid & NA & $\mathrm{NA}$ & 3.6500 & NA & $1 / 1 / 80$ \\
\hline U111 & RAT-U111-2 & Salt & $\mathrm{NA}$ & 39.12 & 0.5200 & 0.85 & $9 / 23 / 80$ \\
\hline $\mathrm{U} 111$ & RAT-U111-3 & Salt & $\mathrm{NA}$ & 33.62 & 0.5400 & 0.81 & $9 / 23 / 80$ \\
\hline B101 & RAT-B101-1 & Sludge & NA & 20.10 & NA & $\mathrm{NA}$ & $1 / 5 / 76$ \\
\hline B102 & RAT-B102-1 & Liquid & NA & 62.60 & NA & NA & $6 / 29 / 73$ \\
\hline B103 & $\mathrm{T}-4289$ & Liquid & $\mathrm{NA}$ & 85.34 & $\mathrm{NA}$ & NA & $5 / 9 / 75$ \\
\hline B105 & RAT-B105-1 & Sludge & NA & 45.70 & NA & NA & $1 / 16 / 76$ \\
\hline B106 & $\mathrm{T}-8577$ & Liquid & NA & 72.77 & $\mathrm{NA}$ & NA & $10 / 6 / 75$ \\
\hline $\mathrm{B} 107$ & RAT-B107-1 & Sludge & $\mathrm{NA}$ & 32.90 & $\mathrm{NA}$ & $\mathrm{NA}$ & $1 / 19 / 76$ \\
\hline
\end{tabular}




\begin{tabular}{|c|c|c|c|c|c|c|c|}
\hline Tank & $\begin{array}{c}\text { Sample } \\
\text { ID }\end{array}$ & $\begin{array}{l}\text { Waste } \\
\text { Phase }\end{array}$ & $\begin{array}{l}(\mathrm{g} / \mathrm{mL}) \\
\text { Density }\end{array}$ & $\% \mathrm{H}_{2} \mathrm{O}$ & $\% \mathrm{TOC}$ & $\begin{array}{c}\text { Dry } \\
\text { \% TOC }\end{array}$ & $\begin{array}{l}\text { Ref. } \\
\text { Date }\end{array}$ \\
\hline$\overline{B 109}$ & $\mathrm{~T}-8578$ & Liquid & $\mathrm{NA}$ & 79.62 & NA & $\mathrm{NA}$ & $10 / 6 / 75$ \\
\hline B203 & 2782 & Sludge & $\mathrm{NA}$ & 74.30 & $\mathrm{NA}$ & NA & $12 / 4 / 78$ \\
\hline BX101 & RAT-BX-101 & Sludge & NA & 29.10 & NA & NA & \\
\hline BX103 & T-8630 & Liquid & NA & 93.28 & NA & NA & \\
\hline C108 & $\mathrm{T}-5489$ & Liquid & NA & 81.94 & NA & $\mathrm{NA}$ & $6 / 19 / 75$ \\
\hline C204 & T-1914 & Sludge & NA & 73.00 & NA & $\mathrm{NA}$ & $12 / 4 / 78$ \\
\hline S101 & $\mathrm{T}-8084$ & Liquid & NA & 81.90 & NA & $\mathrm{NA}$ & $9 / 13 / 74$ \\
\hline S105 & T-737 & Liquid & NA & 48.90 & NA & NA & $1 / 21 / 74$ \\
\hline S106 & $\mathrm{T}-8035$ & Liquid & NA & 46.62 & NA & NA & $12 / 16 / 74$ \\
\hline SX105 & RAT-SX-105- & Salt & NA & 13.00 & $\mathrm{NA}$ & $\mathrm{NA}$ & $2 / 1 / 77$ \\
\hline SX111 & RAT-SX111- & unknown & NA & 33.80 & NA & NA & $8 / 10 / 75$ \\
\hline SX111 & RAT-SX111- & Liquid & NA & 71.30 & $\mathrm{NA}$ & NA & $8 / 1 / 75$ \\
\hline T106 & RAT-T106-1 & Sludge & NA & 36.60 & NA & $\mathrm{NA}$ & $2 / 27 / 75$ \\
\hline T108 & $\mathrm{T}-3391$ & Liquid & NA & 77.80 & $\mathrm{NA}$ & NA & $5 / 13 / 74$ \\
\hline T109 & $\mathrm{T}-2289$ & Liquid & NA & 77.57 & $\mathrm{NA}$ & NA & $3 / 13 / 74$ \\
\hline $\mathrm{T} 110$ & $\mathrm{~T}-5313$ & Liquid & NA & 89.68 & $\mathrm{NA}$ & $\mathrm{NA}$ & $1 / 20 / 75$ \\
\hline TX104 & $\mathrm{T}-4391$ & Liquid & NA & 50.54 & NA & NA & $4 / 19 / 76$ \\
\hline TX113 & $\mathrm{T}-848$ & Liquid & NA & 51.58 & NA & $\mathrm{NA}$ & $1 / 18 / 74$ \\
\hline U102 & RAT-U102-1 & Liquid & NA & 63.60 & NA & $\mathrm{NA}$ & $3 / 1 / 76$ \\
\hline U107 & RAT-U107-1 & Sludge & NA & 50.00 & $\mathrm{NA}$ & $\mathrm{NA}$ & $12 / 9 / 74$ \\
\hline U108 & RAT-U108-1 & Sludge & $\mathrm{NA}$ & 51.20 & NA & $\mathrm{NA}$ & \\
\hline U109 & RAT-U109-1 & Liquid & NA & 63.30 & $\mathrm{NA}$ & N.A & \\
\hline U109 & RAT-U109-1 & Sludge & NA & 36.70 & NA & $\mathrm{NA}$ & \\
\hline $\mathrm{U} 202$ & $\mathrm{~T}-8245$ & Liquid & NA & 79.90 & NA & NA & $9 / 25 / 75$ \\
\hline $\mathrm{U} 204$ & RAT-U204-1 & Sludge & NA & 26.00 & $\mathrm{NA}$ & NA & $12 / 4 / 78$ \\
\hline
\end{tabular}


Appendix G

Moisture Estimates for 149 Single-Shell Tanks 


\begin{tabular}{|c|c|c|c|c|c|c|c|c|c|}
\hline \multirow[b]{2}{*}{ Tank } & \multirow[b]{2}{*}{$\begin{array}{l}\text { 岕 } \\
\text { 胥 } \\
\end{array}$} & \multirow[b]{2}{*}{$\begin{array}{l}\text { Number } \\
\text { of } \\
\text { Samples } \\
\text { for Tank } \\
\text { Waste }\end{array}$} & \multirow[b]{2}{*}{$\begin{array}{l}\text { Number } \\
\text { of } \\
\text { Samples } \\
\text { in } \\
\text { SORWT } \\
\text { Group } \\
\end{array}$} & \multicolumn{3}{|c|}{ Tank Median Estimate } & \multicolumn{3}{|c|}{ Worst $5 \%$ of the Waste } \\
\hline & & & & \begin{tabular}{|l|} 
Tank \\
Median \\
Estimate \\
of \\
Moisture \\
$\%$ \\
\end{tabular} & \begin{tabular}{|l|} 
\\
\\
Relative \\
Standard \\
Deviation on \\
Median \\
\end{tabular} & $\begin{array}{l}95 \% \\
\text { Confidence } \\
\text { Bound on } \\
\text { Tank } \\
\text { Moisture } \\
\text { Estimate } \\
\text { wt\% TOC } \\
\text { (wet) } \\
\end{array}$ & $\begin{array}{l}\text { Estimate } \\
\text { of Worst } \\
5 \% \text { of } \\
\text { Waste, } \\
\text { Moisture }\end{array}$ & $\begin{array}{l}\text { Relative } \\
\text { Standard } \\
\text { Deviation on } \\
\text { Worst } 5 \% \text { of } \\
\text { the Waste }\end{array}$ & $\begin{array}{l}95 \% \\
\text { Confidence } \\
\text { Bound on } \\
\text { Worst } 5 \% \text { of } \\
\text { the Waste }\end{array}$ \\
\hline $\mathrm{A} 101$ & liq & 8 & 19 & 50.4 & \begin{tabular}{|r|}
6.2 \\
\end{tabular} & 44.1 & 34.7 & 11.3 & 26.9 \\
\hline $\mathrm{A} 102$ & liq & 3 & 19 & 48.2 & 10 & 38.6 & 32.5 & 16.4 & 21.8 \\
\hline A103 & liq & 3 & 19 & 52 & 9.2 & 42.4 & 36.4 & 14.7 & 25.7 \\
\hline $\mathrm{A} 105$ & liq & 0 & 0 & 65 & 19.9 & 39.2 & 49.3 & 26.6 & 23.1 \\
\hline A106 & liq & 2 & 2 & 54.6 & 10.7 & 42.9 & 38.9 & 16.2 & 26.3 \\
\hline $\mathrm{AX} 101$ & liq & 5 & 19 & 47.1 & 8.2 & 39.4 & 31.5 & 14.4 & 22.4 \\
\hline $\mathrm{AX102}$ & liq & 0 & 1 & 60 & 20.5 & 35.4 & 44.3 & 28.2 & 19.3 \\
\hline AX103 & liq & 1 & 1 & 53.1 & 14.3 & 38 & 37.4 & 21.2 & 21.6 \\
\hline B101 & liq & 0 & 2 & 68.9 & 17.1 & 45.4 & 53.2 & 22.5 & 29.3 \\
\hline B102 & liq & 1 & 2 & 65.6 & 11.3 & 50.8 & 49.9 & 15.5 & 34.4 \\
\hline B104 & liq & $\overline{0}$ & 0 & 65 & 19.9 & 39.2 & 49.3 & 26.6 & 23.1 \\
\hline B105 & liq & 0 & 1 & 59.6 & 20.6 & 35.1 & 44 & 28.4 & 19 \\
\hline B106 & liq & 1 & 3 & 71.7 & 10.1 & 57.2 & 56 & 13.6 & 40.8 \\
\hline B107 & liq & 0 & 1 & 69.1 & 17.8 & 44.5 & 53.4 & 23.4 & 28.4 \\
\hline B108 & liq & 0 & 1 & 69.1 & 17.8 & 44.5 & 53.4 & 23.4 & 28.4 \\
\hline B109 & liq & 1 & 1 & 74.7 & 10.1 & 59.5 & 59 & 13.4 & 43.1 \\
\hline B110 & liq & 0 & 0 & 65 & 19.9 & 39.2 & 49.3 & 26.6 & 23.1 \\
\hline B111 & liq & 0 & 0 & 65 & 19.9 & 39.2 & 49.3 & 26.6 & 23.1 \\
\hline B112 & liq & 0 & 0 & 65 & 19.9 & 39.2 & 49.3 & 26.6 & 23.1 \\
\hline B201 & liq & 0 & 0 & 65 & 19.9 & 39.2 & 49.3 & 26.6 & 23.1 \\
\hline B202 & liq & 0 & 0 & 65 & 19.9 & 39.2 & 49.3 & 26.6 & 23.1 \\
\hline $\mathrm{B} 203$ & liq & 0 & 0 & 65 & 19.9 & 39.2 & 49.3 & 26.6 & 23.1 \\
\hline $\mathrm{B} 204$ & liq & 0 & 0 & 65 & 19.9 & 39.2 & 49.3 & 26.6 & 23.1 \\
\hline BX101 & liq & 0 & 5 & 71.7 & 15.3 & 49.7 & 56 & 20.1 & 33.5 \\
\hline BX102 & liq & 0 & 5 & 71.7 & 15.3 & 49.7 & 56 & 20.1 & 33.5 \\
\hline BX103 & liq & 1 & 5 & 83.1 & 8.6 & 68.9 & 67.4 & 11.1 & 52.5 \\
\hline BX104 & liq & 1 & 5 & 80.3 & 8.9 & 66.1 & 64.6 & 11.6 & 49.6 \\
\hline BX105 & liq & 1 & 5 & 74.4 & 9.6 & 60.2 & 58.8 & 12.8 & 43.8 \\
\hline BX106 & liq & 1 & 5 & 64.3 & 11.1 & 50.1 & 48.7 & 15.4 & 33.7 \\
\hline BX107 & liq & 0 & 3 & 70.5 & 16.2 & 47.7 & 54.8 & 21.3 & 31.5 \\
\hline BX108 & liq & 0 & 5 & 71.7 & 15.3 & \begin{tabular}{|l|}
49.7 \\
\end{tabular} & 56 & 20.1 & 33.5 \\
\hline BX109 & liq & 1 & 5 & 65.4 & 10.9 & 51.1 & 49.7 & 15.1 & 34.7 \\
\hline BX110 & liq & 0 & 1 & \begin{tabular}{|l|}
61.7 \\
\end{tabular} & 19.9 & 37.2 & 46.1 & 27.1 & 21.1 \\
\hline BX112 & liq & 0 & 1 & 69.1 & 17.8 & 44.5 & 53.4 & 23.4 & 28.4 \\
\hline BY101 & liq & 0 & 3 & 58 & 19.7 & 35.2 & 42.3 & 27.5 & 19 \\
\hline BY102 & liq & 1 & 2 & 57.3 & 12.9 & 42.6 & 41.6 & 18.6 & 26.2 \\
\hline BY103 & liq & 1 & 3 & 54.8 & 13.3 & 40.3 & 39.1 & 19.5 & 23.9 \\
\hline BY104 & liq & 0 & 3 & 58 & 19.7 & 35.2 & 42.3 & 27.5 & 19 \\
\hline BY105 & liq & 1 & 3 & 55.9 & 13 & 41.4 & 40.2 & 19 & 24.9 \\
\hline BY106 & liq & 1 & 3 & 53.8 & 13.5 & 39.2 & 38.1 & 20 & 22.8 \\
\hline BY107 & liq & 0 & 3 & 58 & 19.7 & 35.2 & 42.3 & 27.5 & 19 \\
\hline
\end{tabular}




\begin{tabular}{|c|c|c|c|c|c|c|c|c|c|}
\hline \multirow[b]{2}{*}{ Tank } & \multirow[b]{2}{*}{ 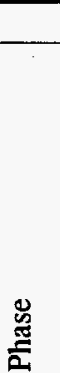 } & \multirow[b]{2}{*}{$\begin{array}{l}\text { Number } \\
\text { of } \\
\text { Samples } \\
\text { for Tank } \\
\text { Waste }\end{array}$} & \multirow[b]{2}{*}{$\begin{array}{l}\text { Number } \\
\text { of } \\
\text { Samples } \\
\text { in } \\
\text { SORWT } \\
\text { Group }\end{array}$} & \multicolumn{3}{|c|}{ Tank Median Estimate } & \multicolumn{3}{|c|}{ Worst $5 \%$ of the Waste } \\
\hline & & & & $\begin{array}{l}\text { Tank } \\
\text { Median } \\
\text { Estimate } \\
\text { of } \\
\text { Moisture } \\
\%\end{array}$ & \begin{tabular}{|l|} 
\\
Relative \\
Standard \\
Deviation on \\
Median
\end{tabular} & \begin{tabular}{|l|}
$95 \%$ \\
Confidence \\
Bound on \\
Tank \\
Moisture \\
Estimate \\
wt\% TOC \\
(wet) \\
\end{tabular} & \begin{tabular}{|l|} 
Estimate \\
of Worst \\
$5 \%$ of \\
Waste, \\
Moisture
\end{tabular} & $\begin{array}{l}\text { Relative } \\
\text { Standard } \\
\text { Deviation on } \\
\text { Worst } 5 \% \text { of } \\
\text { the Waste }\end{array}$ & \begin{tabular}{|l}
$95 \%$ \\
Confidence \\
Bound on \\
Worst $5 \%$ of \\
the Waste
\end{tabular} \\
\hline BY108 & liq & 0 & 3 & 58 & 19.7 & 35.2 & 42.3 & 27.5 & 19 \\
\hline BY109 & liq & 1 & 2 & 59.4 & 12.4 & 44.7 & 43.8 & 17.7 & 28.3 \\
\hline BY110 & liq & 0 & 3 & 58 & 19.7 & 35.2 & 42.3 & 27.5 & 19 \\
\hline BY112 & liq & 0 & 3 & 58 & 19.7 & 35.2 & 42.3 & 27.5 & 19 \\
\hline $\mathrm{C} 101$ & liq & 0 & 5 & 71.7 & 15.3 & 49.7 & 56 & 20.1 & 33.5 \\
\hline $\mathrm{C} 102$ & liq & 0 & 0 & 65 & 19.9 & 39.2 & 49.3 & 26.6 & 23.1 \\
\hline $\mathrm{C} 103$ & liq & 1 & 1 & 80.1 & 9.5 & 64.9 & 64.4 & 12.3 & 48.5 \\
\hline $\mathrm{C} 104$ & liq & 1 & 1 & 72.7 & 10.4 & 57.6 & 57 & 13.9 & $\overline{41.2}$ \\
\hline $\mathrm{C} 105$ & liq & 0 & 0 & 65 & 19.9 & 39.2 & 49.3 & 26.6 & 23.1 \\
\hline $\mathrm{C} 106$ & liq & 0 & 1 & 71.4 & 17.2 & 46.8 & 55.7 & 22.4 & 30.7 \\
\hline $\mathrm{C} 107$ & liq & 0 & 0 & 65 & 19.9 & 39.2 & 49.3 & 26.6 & 23.1 \\
\hline $\mathrm{C109}$ & liq & 1 & 7 & 72.2 & 9.9 & 57.9 & 56.5 & 13.3 & 41.5 \\
\hline $\mathrm{C} 110$ & liq & 1 & 3 & 72.9 & 10 & 58.3 & 57.2 & 13.3 & 41.9 \\
\hline $\mathrm{C} 112$ & liq & 2 & 7 & 60.7 & 9.3 & 49.4 & 45 & 13.6 & 32.8 \\
\hline S101 & liq & 1 & 16 & 71.5 & 9.7 & 57.6 & 55.8 & 13.1 & 41.1 \\
\hline$\$ 102$ & liq & 2 & 16 & 60.7 & 9.1 & 49.6 & 45 & 13.4 & 33 \\
\hline$S 103$ & liq & 0 & 16 & 59.7 & 17.5 & 38.8 & 44 & 24.3 & 22.6 \\
\hline S104 & liq & 0 & 1 & 66.2 & 18.5 & 41.7 & 50.5 & 24.7 & 25.5 \\
\hline S105 & liq & 1 & 16 & 54 & 12.9 & 40.1 & 38.3 & 19.1 & 23.7 \\
\hline S106 & liq & 1 & 16 & 52.8 & 13.1 & 38.9 & 37.1 & 19.7 & 22.5 \\
\hline $\mathbf{S 1 0 7}$ & liq & 3 & 16 & 52.6 & 9.1 & 43 & 36.9 & 14.4 & 26.3 \\
\hline$\$ 108$ & liq & 0 & 16 & 59.7 & 17.5 & 38.8 & 44 & 24.3 & 22.6 \\
\hline $\mathbf{S 1 0 9}$ & liq & 0 & 16 & 59.7 & 17.5 & 38.8 & 44 & 24.3 & 22.6 \\
\hline$\$ 110$ & liq & 0 & 16 & 59.7 & 17.5 & 38.8 & 44 & 24.3 & 22.6 \\
\hline S111 & liq & 1 & 16 & 51.7 & 13.4 & 37.8 & 36 & 20.3 & 21.4 \\
\hline $\mathbf{S} 112$ & liq & 0 & 16 & 59.7 & 17.5 & 38.8 & 44 & 24.3 & 22.6 \\
\hline SX101 & liq & 2 & 16 & 84.3 & 6.6 & 73.2 & 68.6 & 8.8 & 56.5 \\
\hline SX102 & liq & 0 & 16 & 59.7 & 17.5 & 38.8 & 44 & 24.3 & 22.6 \\
\hline SX103 & liq & 0 & 16 & 59.7 & 17.5 & $\begin{array}{l}38.8 \\
\end{array}$ & 44 & 24.3 & 22.6 \\
\hline SX104 & liq & 2 & 16 & 57.4 & 9.7 & 46.3 & 41.7 & 14.4 & 29.7 \\
\hline SX105 & liq & 0 & 16 & 59.7 & 17.5 & 38.8 & 44 & 24.3 & 22.6 \\
\hline SX106 & liq & 2 & 16 & 50.3 & 11 & 39.1 & 34.6 & 17.4 & 22.5 \\
\hline SX107 & liq & 1 & 1 & 67.9 & 11.2 & 52.7 & 52.2 & 15.2 & 36.3 \\
\hline SX108 & liq & 0 & 1 & 66.2 & 18.5 & 41.7 & 50.5 & 24.7 & 25.5 \\
\hline SX109 & liq & 0 & 1 & 66.2 & 18.5 & 41.7 & 50.5 & 24.7 & 25.5 \\
\hline SX111 & liq & 1 & 1 & 69.2 & 10.9 & 54 & 53.5 & 14.8 & 37.6 \\
\hline SX112 & liq & 0 & 1 & 66.2 & 18.5 & 41.7 & 50.5 & 24.7 & 25.5 \\
\hline SX114 & liq & 0 & 1 & 66.8 & 18.4 & 42.2 & 51.1 & 24.5 & 26.1 \\
\hline T101 & liq & 0 & 0 & 65 & 19.9 & 39.2 & 49.3 & 26.6 & 23.1 \\
\hline T102 & liq & 0 & 0 & 65 & 19.9 & 39.2 & 49.3 & 26.6 & 23.1 \\
\hline T103 & liq & 0 & 0 & 65 & 19.9 & 39.2 & 49.3 & 26.6 & 23.1 \\
\hline
\end{tabular}




\begin{tabular}{|c|c|c|c|c|c|c|c|c|c|}
\hline \multirow[b]{2}{*}{ Tank } & \multirow[b]{2}{*}{ 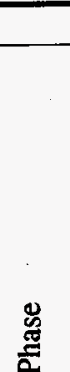 } & \multirow[b]{2}{*}{\begin{tabular}{|l}
$\begin{array}{l}\text { Number } \\
\text { of } \\
\text { Samples } \\
\text { for Tank } \\
\text { Waste }\end{array}$ \\
\end{tabular}} & \multirow[b]{2}{*}{$\begin{array}{l}\text { Number } \\
\text { of } \\
\text { Samples } \\
\text { in } \\
\text { SORWT } \\
\text { Group }\end{array}$} & \multicolumn{3}{|c|}{ Tank Median Estimate } & \multicolumn{3}{|c|}{ Worst $5 \%$ of the Waste } \\
\hline & & & & \begin{tabular}{|l} 
Tank \\
Median \\
Estimate \\
of \\
Moisture \\
$\%$
\end{tabular} & $\begin{array}{l}\text { Relative } \\
\text { Standard } \\
\text { Deviation on } \\
\text { Median }\end{array}$ & \begin{tabular}{|l|}
$95 \%$ \\
Confidence \\
Bound on \\
Tank \\
Moisture \\
Estimate \\
wt\% TOC \\
(wet) \\
\end{tabular} & $\begin{array}{l}\text { Estimate } \\
\text { of Worst } \\
5 \% \text { of } \\
\text { Waste, } \\
\text { Moisture }\end{array}$ & $\begin{array}{l}\text { Relative } \\
\text { Standard } \\
\text { Deviation on } \\
\text { Worst } 5 \% \text { of } \\
\text { the Waste }\end{array}$ & $\begin{array}{l}95 \% \\
\text { Confidence } \\
\text { Bound on } \\
\text { Worst } 5 \% \text { of } \\
\text { the Waste }\end{array}$ \\
\hline T104 & liq & 0 & 0 & 65 & 19.9 & 39.2 & 49.3 & 26.6 & 23.1 \\
\hline T105 & liq & 0 & 0 & 65 & 19.9 & 39.2 & 49.3 & 26.6 & 23.1 \\
\hline T106 & liq & 0 & 0 & 65 & 19.9 & 39.2 & 49.3 & 26.6 & 23.1 \\
\hline T107 & liq & 3 & 7 & 80.9 & 6 & 71.2 & 65.2 & 8.2 & 54.5 \\
\hline $\mathrm{T} 110$ & liq & 1 & 2 & 82.9 & 8.9 & 68.1 & 67.2 & 11.5 & 51.7 \\
\hline T111 & liq & 0 & 2 & 75.3 & 15.6 & 51.8 & 59.6 & 20.1 & 35.6 \\
\hline T112 & liq & 1 & 2 & 81.7 & 9 & 66.9 & 66 & 11.7 & 50.5 \\
\hline T201 & liq & 0 & 0 & 65 & 19.9 & 39.2 & 49.3 & 26.6 & 23.1 \\
\hline $\mathrm{T} 202$ & liq & 0 & 0 & 65 & 19.9 & 39.2 & 49.3 & 26.6 & 23.1 \\
\hline T203 & liq & 0 & 0 & 65 & 19.9 & 39.2 & 49.3 & 26.6 & 23.1 \\
\hline T204 & liq & 0 & 0 & 65 & 19.9 & 39.2 & 49.3 & 26.6 & 23.1 \\
\hline TX101 & liq & 0 & 0 & 65 & 19.9 & 39.2 & 49.3 & 26.6 & 23.1 \\
\hline TX102 & liq & 0 & 16 & 59.7 & $\mathbf{1 7 . 5}$ & 38.8 & 44 & 24.3 & 22.6 \\
\hline $\mathrm{TX103}$ & liq & 1 & 2 & 57.5 & 12.9 & 42.7 & 41.8 & 18.5 & 26.3 \\
\hline TX104 & liq & 1 & 16 & 54.9 & 12.6 & 41 & 39.2 & 18.7 & 24.5 \\
\hline TX105 & liq & 0 & 16 & 59.7 & 17.5 & 38.8 & 44 & 24.3 & 22.6 \\
\hline TX106 & liq & 0 & 16 & 59.7 & 17.5 & 38.8 & 44 & 24.3 & 22.6 \\
\hline TX107 & $\operatorname{liq}$ & 0 & 16 & 59.7 & 17.5 & 38.8 & 44 & 24.3 & 22.6 \\
\hline TX109 & liq & 0 & 1 & 59.6 & 20.6 & 35.1 & 44 & 28.4 & 19 \\
\hline TX110 & liq & 1 & 1 & 52.3 & 14.5 & 37.2 & 36.6 & 21.6 & 20.8 \\
\hline TX111 & liq & 0 & 1 & 59.6 & 20.6 & 35.1 & 44 & 28.4 & 19 \\
\hline $\mathrm{TX} 112$ & liq & 0 & 1 & 59.6 & 20.6 & 35.1 & 44 & 28.4 & 19 \\
\hline TX113 & liq & 1 & 1 & 59.6 & 20.6 & 35.1 & 44 & 28.4 & 19 \\
\hline TX114 & liq & 0 & 1 & 59.6 & 20.6 & 35.1 & 44 & 28.4 & 19 \\
\hline TX115 & liq & 0 & 3 & 63.9 & 17.9 & 41 & 48.2 & 24.2 & 24.9 \\
\hline TX116 & liq & 0 & 1 & 59.6 & 20.6 & 35.1 & 44 & 28.4 & 19 \\
\hline TX117 & liq & 0 & 1 & 59.6 & 20.6 & 35.1 & 44 & 28.4 & 19 \\
\hline TX118 & liq & 0 & 2 & 60.1 & 19.6 & 36.6 & 44.4 & 27 & 20.5 \\
\hline TY102 & liq & 0 & 1 & 59.6 & 20.6 & 35.1 & 44 & 28.4 & 19 \\
\hline TY103 & liq & 0 & 0 & 65 & 19.9 & 39.2 & 49.3 & 26.6 & 23.1 \\
\hline TY104 & liq & 0 & 0 & 65 & 19.9 & 39.2 & 49.3 & 26.6 & 23.1 \\
\hline U101 & liq & 0 & 1 & 66.2 & 18.5 & 41.7 & 50.5 & 24.7 & 25.5 \\
\hline U102 & liq & 1 & 3 & \begin{tabular}{|c|}
63.7 \\
\end{tabular} & 11.4 & 49.2 & 48 & 15.9 & 32.8 \\
\hline U103 & liq & 1 & 3 & 63.5 & 11.4 & 49 & 47.8 & 16 & 32.6 \\
\hline U104 & liq & 0 & 0 & 65 & 19.9 & 39.2 & 49.3 & 26.6 & 23.1 \\
\hline U105 & liq & 0 & 1 & 64.5 & 19 & 40 & 48.9 & 25.6 & 23.9 \\
\hline U106 & liq & 1 & 3 & 62.8 & 11.6 & 48.3 & 47.2 & 16.2 & 31.9 \\
\hline U107 & liq & 0 & 1 & 64.5 & 19 & 40 & 48.9 & 25.6 & 23.9 \\
\hline U108 & liq & 0 & 1 & 64.5 & 19 & 40 & 48.9 & 25.6 & 23.9 \\
\hline U109 & liq & 1 & 1 & 63.9 & 11.9 & 48.7 & 48.2 & 16.4 & 32.4 \\
\hline $\mathrm{U} 110$ & liq & 0 & 0 & 65 & 19.9 & 39.2 & 49.3 & 26.6 & 23.1 \\
\hline
\end{tabular}




\begin{tabular}{|c|c|c|c|c|c|c|c|c|c|}
\hline \multirow[b]{2}{*}{ Tank } & \multirow[b]{2}{*}{ 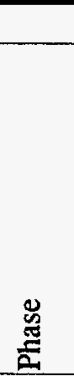 } & \multirow[b]{2}{*}{$\begin{array}{l}\text { Number } \\
\text { of } \\
\text { Samples } \\
\text { for Tank } \\
\text { Waste }\end{array}$} & \multirow[b]{2}{*}{\begin{tabular}{|l} 
Number \\
lof \\
Samples \\
in \\
SORWT \\
Group
\end{tabular}} & \multicolumn{3}{|c|}{ Tank Median Estimate } & \multicolumn{3}{|c|}{ Worst $5 \%$ of the Waste } \\
\hline & & & & $\begin{array}{l}\text { Tank } \\
\text { Median } \\
\text { Estimate } \\
\text { of } \\
\text { Moisture } \\
\%\end{array}$ & \begin{tabular}{|l|} 
\\
Relative \\
Standard \\
Deviation on \\
Median
\end{tabular} & \begin{tabular}{|l|}
$95 \%$ \\
Confidence \\
Bound on \\
Tank \\
Moisture \\
Estimate \\
wt\% TOC \\
(wet) \\
\end{tabular} & $\begin{array}{l}\text { Estimate } \\
\text { of Worst } \\
5 \% \text { of } \\
\text { Waste, } \\
\text { Moisture }\end{array}$ & $\begin{array}{l}\text { Relative } \\
\text { Standard } \\
\text { Deviation on } \\
\text { Worst } 5 \% \text { of } \\
\text { the Waste } \\
\end{array}$ & $\begin{array}{l}95 \% \\
\text { Confidence } \\
\text { Bound on } \\
\text { Worst } 5 \% \text { of } \\
\text { the Waste }\end{array}$ \\
\hline U111 & liq & 0 & 3 & 63.9 & 17.9 & 41 & 48.2 & 24.2 & 24.9 \\
\hline U112 & liq & 0 & 0 & 65 & 19.9 & 39.2 & 49.3 & 26.6 & 23.1 \\
\hline U201 & liq & 0 & 1 & 69.2 & 17.7 & 44.6 & 53.5 & 23.4 & 28.5 \\
\hline U202 & liq & 1 & 1 & 74.9 & 10.1 & 59.7 & 59.2 & 13.4 & 43.3 \\
\hline $\mathrm{U} 203$ & liq & 0 & 1 & 69.2 & 17.7 & 44.6 & 53.5 & 23.4 & 28.5 \\
\hline U204 & liq & 0 & 0 & 65 & 19.9 & 39.2 & 49.3 & 26.6 & 23.1 \\
\hline A101 & salt & 2 & 2 & 39.1 & 11.1 & 31.4 & 28.2 & 16.3 & 20.3 \\
\hline $\mathrm{A} 102$ & salt & 0 & 2 & 43.1 & 24.9 & 26.2 & 31 & 27.6 & 17.8 \\
\hline AX101 & salt & 0 & 2 & 43.1 & 24.9 & 26.2 & 31 & 27.6 & 17.8 \\
\hline $\mathrm{AX102}$ & salt & 0 & 0 & 43.1 & 24.9 & 26.2 & 31 & 27.6 & 17.8 \\
\hline AX103 & salt & 0 & 0 & 43.1 & 24.9 & 26.2 & 31 & 27.6 & 17.8 \\
\hline B102 & salt & 0 & 0 & 43.1 & 24.9 & 26.2 & 31 & 27.6 & 17.8 \\
\hline B104 & salt & 0 & 0 & 43.1 & 24.9 & 26.2 & 31 & 27.6 & 17.8 \\
\hline B105 & salt & 0 & 1 & 43.1 & 24.9 & 26.2 & 31 & 27.6 & 17.8 \\
\hline BX105 & salt & 0 & 0 & 43.1 & 24.9 & 26.2 & 31 & 27.6 & 17.8 \\
\hline $\mathrm{BX} 110$ & salt & 0 & 0 & 48.4 & 14.3 & 36.3 & 34.8 & 18.7 & 24 \\
\hline BX111 & salt & 0 & 0 & 43.1 & 24.9 & 26.2 & 31 & 27.6 & 17.8 \\
\hline BY101 & salt & 0 & 4 & 16.9 & 32.3 & 8.9 & 12.2 & 34.5 & 6.1 \\
\hline BY102 & salt & 0 & 0 & 43.1 & 24.9 & 26.2 & 31 & 27.6 & 17.8 \\
\hline BY103 & salt & 0 & 4 & 43.1 & 24.9 & 26.2 & 31 & 27.6 & 17.8 \\
\hline BY104 & salt & 4 & 4 & 16.1 & 8.7 & 13.5 & 11.6 & 14.7 & 8.6 \\
\hline BY105 & salt & 0 & 4 & 43.1 & 24.9 & 26.2 & 31 & 27.6 & 17.8 \\
\hline BY106 & salt & 0 & 4 & 43.1 & 24.9 & 26.2 & 31 & 27.6 & 17.8 \\
\hline BY107 & salt & 0 & 4 & $\begin{array}{ll}16.9 \\
\end{array}$ & 32.3 & 8.9 & 12.2 & 34.5 & 6.1 \\
\hline BY108 & salt & 0 & 4 & 16.9 & 32.3 & 8.9 & 12.2 & 34.5 & 6.1 \\
\hline BY109 & salt & 0 & 0 & 43.1 & 24.9 & 26.2 & 31 & 27.6 & 17.8 \\
\hline BY110 & salt & 0 & 4 & 16.9 & 32.3 & 8.9 & 12.2 & 34.5 & 6.1 \\
\hline BY111 & salt & 0 & 4 & 16.9 & 32.3 & 8.9 & 12.2 & 34.5 & 6.1 \\
\hline BY112 & salt & 0 & 4 & 16.9 & 32.3 & 8.9 & 12.2 & 34.5 & 6.1 \\
\hline S101 & salt & 0 & 6 & 21.6 & 26.8 & 12.6 & 15.5 & \begin{tabular}{|l|}
29.3 \\
\end{tabular} & 8.7 \\
\hline S102 & salt & 0 & 6 & 21.6 & 26.8 & 12.6 & 15.5 & 29.3 & 8.7 \\
\hline S103 & salt & 0 & 6 & 21.6 & 26.8 & 12.6 & 15.5 & 29.3 & 8.7 \\
\hline $\mathbf{S 1 0 5}$ & salt & 0 & 6 & 8.5 & 36.9 & 4.1 & 6.1 & 38.7 & 2.8 \\
\hline$\$ 106$ & salt & 0 & 6 & 21.6 & 26.8 & 12.6 & 15.5 & 29.3 & 8.7 \\
\hline S107 & salt & 0 & 6 & 21.6 & 26.8 & 12.6 & 15.5 & 29.3 & 8.7 \\
\hline$\$ 108$ & salt & 0 & 6 & 21.6 & 26.8 & 12.6 & 15.5 & 29.3 & 8.7 \\
\hline S109 & salt & 0 & 6 & 21.6 & 26.8 & 12.6 & 15.5 & 29.3 & 8.7 \\
\hline $\mathbf{S} 110$ & salt & 0 & 6 & 21.6 & 26.8 & 12.6 & 15.5 & 29.3 & 8.7 \\
\hline S111 & salt & 3 & 6 & 15.9 . & 9.5 & 13.2 & 11.5 & 15.3 & 8.4 \\
\hline $\mathbf{S 1 1 2}$ & salt & 0 & 6 & 21.6 & 26.8 & 12.6 & 15.5 & 29.3 & 8.7 \\
\hline SX101 & salt & 0 & 6 & 12.4 & 26.3 & 7.3 & 8.9 & 28.9 & 5 \\
\hline
\end{tabular}




\begin{tabular}{|c|c|c|c|c|c|c|c|c|c|}
\hline \multirow[b]{2}{*}{ Tank } & \multirow[b]{2}{*}{ 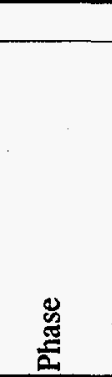 } & \multirow[b]{2}{*}{$\begin{array}{l}\text { Number } \\
\text { of } \\
\text { Samples } \\
\text { for Tank } \\
\text { Waste }\end{array}$} & \multirow[b]{2}{*}{\begin{tabular}{|l} 
Number \\
of \\
Samples \\
in \\
SORWT \\
Group \\
\end{tabular}} & \multicolumn{3}{|c|}{ Tank Median Estimate } & \multicolumn{3}{|c|}{ Worst $5 \%$ of the Waste } \\
\hline & & & & $\begin{array}{l}\text { Tank } \\
\text { Median } \\
\text { Estimate } \\
\text { of } \\
\text { Moisture } \\
\%\end{array}$ & \begin{tabular}{|l|} 
\\
\\
Relative \\
Standard \\
Deviation on \\
Median
\end{tabular} & \begin{tabular}{|l}
$95 \%$ \\
Confidence \\
Bound on \\
Tank \\
Moisture \\
Estimate \\
wt\% TOC \\
(wet)
\end{tabular} & $\begin{array}{l}\text { Estimate } \\
\text { of Worst } \\
5 \% \text { of } \\
\text { Waste, } \\
\text { Moisture }\end{array}$ & $\begin{array}{l}\text { Relative } \\
\text { Standard } \\
\text { Deviation on } \\
\text { Worst } 5 \% \text { of } \\
\text { the Waste }\end{array}$ & \begin{tabular}{|l}
$95 \%$ \\
Confidence \\
Bound on \\
Worst 5\% of \\
the Waste
\end{tabular} \\
\hline SX102 & salt & 1 & 6 & 13.3 & 14.7 & $\begin{array}{l}7 \\
\end{array}$ & 9.6 & \begin{tabular}{|l|}
19 \\
\end{tabular} & 6.5 \\
\hline$S \times 103$ & salt & 0 & 6 & 12.4 & 26.3 & 7.3 & 8.9 & 28.9 & 5 \\
\hline SX104 & salt & 0 & 6 & 11.8 & 14.7 & 8.8 & 8.5 & 19 & 5.8 \\
\hline SX105 & salt & 1 & 6 & 12.8 & 14.7 & 9.5 & 9.2 & 19 & 6.3 \\
\hline SX106 & salt & 1 & 6 & 12.4 & 26.3 & 7.3 & 8.9 & 28.9 & 5 \\
\hline $\mathrm{TX} 102$ & salt & 0 & 6 & 8.5 & 36.9 & 4.1 & 6.1 & 38.7 & 2.8 \\
\hline TX104 & salt & 0 & 6 & 21.6 & 26.8 & 12.6 & 15.5 & 29.3 & 8.7 \\
\hline TX105 & salt & 0 & 6 & 8.5 & 36.9 & 4.1 & 6.1 & 38.7 & 2.8 \\
\hline TX106 & salt & 0 & 6 & 8.5 & 36.9 & 4.1 & 6.1 & 38.7 & 2.8 \\
\hline TX107 & salt & 0 & 6 & 21.6 & 26.8 & 12.6 & 15.5 & 29.3 & 8.7 \\
\hline TX108 & salt & 0 & 0 & 16.9 & 32.3 & 8.9 & 12.2 & 34.5 & 6.1 \\
\hline TX109 & salt & 0 & 1 & 16.9 & 32.3 & 8.9 & 12.2 & 34.5 & 6.1 \\
\hline TX110 & salt & 0 & 1 & 16.9 & 32.3 & 8.9 & 12.2 & 34.5 & 6.1 \\
\hline TX111 & salt & 0 & 1 & 16.9 & 32.3 & 8.9 & 12.2 & 34.5 & 6.1 \\
\hline TX112 & salt & 0 & 1 & 16.9 & 32.3 & 8.9 & 12.2 & 34.5 & 6.1 \\
\hline TX113 & salt & 0 & 1 & 16.9 & 32.3 & 8.9 & 12.2 & 34.5 & 6.1 \\
\hline TX114 & salt & 0 & 1 & 16.9 & 32.3 & 8.9 & 12.2 & 34.5 & 6.1 \\
\hline TX115 & salt & 0 & 2 & 16.9 & 32.3 & 8.9 & 12.2 & 34.5 & 6.1 \\
\hline TX116 & salt & 0 & 1 & 16.9 & 32.3 & 8.9 & 12.2 & 34.5 & 6.1 \\
\hline TX117 & salt & 0 & 1 & 16.9 & 32.3 & 8.9 & 12.2 & 34.5 & 6.1 \\
\hline TX118 & salt & 0 & 0 & 16.9 & 32.3 & 8.9 & 12.2 & 34.5 & 6.1 \\
\hline TY102 & salt & 1 & 1 & 51.9 & 14.3 & 38.9 & 37.3 & 18.7 & 25.7 \\
\hline $\mathrm{U} 102$ & salt & 0 & 2 & 43.1 & 24.9 & 26.2 & 31 & 27.6 & 17.8 \\
\hline U103 & salt & 0 & 2 & 43.1 & 24.9 & 26.2 & 31 & 27.6 & 17.8 \\
\hline U105 & salt & 1 & 1 & 21.1 & 14.8 & 15.7 & 15.2 & 19 & 10.4 \\
\hline $\mathrm{U} 106$ & salt & 0 & 2 & 43.1 & 24.9 & 26.2 & 31 & 27.6 & 17.8 \\
\hline U107 & salt & 0 & 1 & 21.6 & 26.8 & 12.6 & 15.5 & 29.3 & 8.7 \\
\hline U108 & salt & 0 & 1 & 21.6 & 26.8 & 12.6 & 15.5 & 29.3 & 8.7 \\
\hline U109 & salt & 0 & 1 & 30.4 & 14.8 & 22.6 & 21.8 & 19 & 14.9 \\
\hline U111 & salt & 2 & 2 & 37.7 & 11.1 & 30.2 & 27.2 & 16.3 & 19.6 \\
\hline A101 & sludge & 0 & 4 & 39.5 & 14 & 28.5 & 18.4 & 31.1 & 6.9 \\
\hline $\mathrm{A} 102$ & sludge & 2 & 4 & 39.5 & 14 & 28.5 & 18.4 & 31.1 & 6.9 \\
\hline A103 & sludge & 2 & 4 & 39.5 & 14 & 28.5 & 18.4 & 31.1 & 6.9 \\
\hline A104 & sludge & 0 & 0 & 44.7 & 24 & 23.3 & 23.6 & 45.9 & 2 \\
\hline A105 & sludge & 0 & 0 & 44.7 & 24 & 23.3 & 23.6 & 45.9 & 2 \\
\hline A106 & sludge & 2 & 2 & 44.3 & 15.8 & 30.3 & 23.2 & 30.9 & 8.9 \\
\hline AX101 & sludge & 0 & 4 & 39.5 & 14 & 28.5 & 18.4 & 31.1 & 6.9 \\
\hline $\mathrm{AX} 102$ & sludge & 0 & 0 & 44.7 & 24 & 23.3 & 23.6 & 45.9 & 2 \\
\hline $\mathrm{AX} 103$ & sludge & 0 & 0 & 44.7 & 24 & 23.3 & 23.6 & 45.9 & 2 \\
\hline AX104 & sludge & 0 & 0 & 44.7 & 24 & 23.3 & 23.6 & 45.9 & 2 \\
\hline B101 & sludge & 1 & 1 & 34.5 & 24.3 & 17.7 & 13.4 & 63.6 & -3.6 \\
\hline
\end{tabular}




\begin{tabular}{|c|c|c|c|c|c|c|c|c|c|}
\hline & & & & \multicolumn{3}{|c|}{ Tank Median Estimate } & \multicolumn{3}{|c|}{ Worst $5 \%$ of the Waste } \\
\hline Tank & 岕 & $\begin{array}{l}\text { Number } \\
\text { of } \\
\text { Samples } \\
\text { for Tank } \\
\text { Waste }\end{array}$ & $\begin{array}{l}\text { Number } \\
\text { of } \\
\text { Samples } \\
\text { in } \\
\text { SORWT } \\
\text { Group }\end{array}$ & $\begin{array}{l}\text { Tank } \\
\text { Median } \\
\text { Estimate } \\
\text { of } \\
\text { Moisture } \\
\%\end{array}$ & $\begin{array}{l}\text { Relative } \\
\text { Standard } \\
\text { Deviation on } \\
\text { Median }\end{array}$ & \begin{tabular}{|l}
$95 \%$ \\
Confidence \\
Bound on \\
Tank \\
Moisture \\
Estimate \\
wt \% TOC \\
(wet)
\end{tabular} & $\begin{array}{l}\text { Estimate } \\
\text { of Worst } \\
5 \% \text { of } \\
\text { Waste, } \\
\text { Moisture }\end{array}$ & \begin{tabular}{|l|} 
Relative \\
Standard \\
Deviation on \\
Worst $5 \%$ of \\
the Waste
\end{tabular} & $\begin{array}{l}95 \% \\
\text { Confidence } \\
\text { Bound on } \\
\text { Worst } 5 \% \text { of } \\
\text { the Waste }\end{array}$ \\
\hline B102 & sludge & 0 & 1 & 34.5 & 24.3 & 17.7 & 13.4 & 63.6 & -3.6 \\
\hline B103 & sludge & 0 & 1 & 34.5 & 24.3 & 17.7 & 13.4 & 63.6 & -3.6 \\
\hline B104 & sludge & 0 & 0 & 44.7 & 24 & 23.3 & 23.6 & 45.9 & 2 \\
\hline B105 & sludge & 1 & 1 & 45.1 & 18.6 & 28.4 & 24 & 35.5 & 7 \\
\hline B106 & sludge & 0 & 15 & 49.5 & 6.4 & 43.1 & 28.3 & 12.3 & 21.3 \\
\hline B107 & sludge & 1 & 3 & 47.8 & 12.8 & 35.6 & 26.7 & 23.7 & 14.1 \\
\hline B108 & sludge & 0 & 3 & 47.8 & 12.8 & 35.6 & 26.7 & 23.7 & 14.1 \\
\hline B109 & sludge & 0 & 3 & 47.8 & 12.8 & 35.6 & 26.7 & 23.7 & 14.1 \\
\hline B110 & sludge & 0 & 0 & 44.7 & 24 & 23.3 & 23.6 & 45.9 & 2 \\
\hline B111 & sludge & 0 & 0 & 44.7 & 24 & 23.3 & 23.6 & 45.9 & 2 \\
\hline B112 & sludge & 0 & 0 & 44.7 & 24 & 23.3 & 23.6 & 45.9 & 2 \\
\hline B201 & sludge & 1 & 7 & 64.9 & 6.8 & 56 & 43.8 & 10.7 & 34.4 \\
\hline B202 & sludge & 2 & 7 & 64.9 & 6.8 & 56 & 43.8 & 10.7 & 34.4 \\
\hline B203 & sludge & 1 & 7 & 64.9 & 6.8 & 56 & 43.8 & 10.7 & 34.4 \\
\hline B204 & sludge & 2 & 7 & $\mid 64.9$ & 6.8 & 56 & \begin{tabular}{|l|}
43.8 \\
\end{tabular} & \begin{tabular}{|l|}
10.7 \\
\end{tabular} & 34.4 \\
\hline $\mathrm{BX} 101$ & sludge & 1 & 1 & 38.2 & 21.9 & 21.5 & 17.1 & 49.7 & 0.1 \\
\hline $\mathrm{BX} 102$ & sludge & 0 & 1 & 38.2 & 21.9 & 21.5 & 17.1 & \begin{tabular}{l|l}
49.7 \\
\end{tabular} & 0.1 \\
\hline BX103 & sludge & 0 & 1 & 38.2 & 21.9 & 21.5 & 17.1 & 49.7 & 0.1 \\
\hline BX104 & sludge & 0 & 1 & 38.2 & 21.9 & 21.5 & 17.1 & 49.7 & 0.1 \\
\hline BX105 & sludge & 0 & 1 & 38.2 & 21.9 & 21.5 & 17.1 & 49.7 & 0.1 \\
\hline BX106 & sludge & 0 & 1 & 38.2 & 21.9 & 21.5 & 17.1 & 49.7 & 0.1 \\
\hline BX107 & sludge & 15 & 15 & 49.5 & 6.4 & 43.1 & 28.3 & 12.3 & 21.3 \\
\hline BX108 & sludge & 0 . & 1 & 38.2 & 21.9 & 21.5 & 17.1 & 49.7 & 0.1 \\
\hline $\mathrm{BX} 109$ & sludge & 0 & 1 & 38.2 & 21.9 & 21.5 & 17.1 & 49.7 & 0.1 \\
\hline $\mathrm{BX} 110$ & sludge & 1 & 2 & 48.9 & 14.3 & 34.9 & 27.8 & 25.7 & 13.5 \\
\hline $\mathrm{BX} 111$ & sludge & 1 & 2 & 48.9 & 14.3 & 34.9 & 27.8 & 25.7 & 13.5 \\
\hline $\mathrm{BX} 112$ & sludge & 2 & 3 & 47.8 & 12.8 & 35.6 & 26.7 & 23.7 & 14.1 \\
\hline BY101 & sludge & 0 & 1 & 37.9 & 22.1 & 21.1 & 16.8 & 50.7 & 0 \\
\hline BY103 & sludge & 0 & 1 & 37.9 & 22.1 & 21.1 & 16.8 & 50.7 & 0 \\
\hline BY104 & sludge & 1 & 1 & 37.9 & 22.1 & 21.1 & 16.8 & 50.7 & 0 \\
\hline BY105 & sludge & 0 & 1 & 37.9 & 22.1 & 21.1 & 16.8 & 50.7 & 0 \\
\hline BY106 & sludge & 0 & 1 & 37.9 & 22.1 & 21.1 & 16.8 & 50.7 & 0 \\
\hline BY107 & sludge & 0 & 1 & 37.9 & 22.1 & 21.1 & 16.8 & 50.7 & $\overline{0}$ \\
\hline BY108 & sludge & 0 & 1 & 37.9 & 22.1 & 21.1 & 16.8 & \begin{tabular}{|l|}
50.7 \\
\end{tabular} & 0 \\
\hline BY109 & sludge & 0 & 0 & 44.7 & 24 & 23.3 & 23.6 & 45.9 & 2 \\
\hline BY110 & sludge & 0 & 1 & 37.9 & 22.1 & 21.1 & 16.8 & 50.7 & 0 \\
\hline BY111 & sludge & 0 & 1 & 37.9 & 22.1 & 21.1 & 16.8 & S0.7 & 0 \\
\hline BY112 & sludge & 0 & 1 & 37.9 & 22.1 & 21.1 & 16.8 & 50.7 & 0 \\
\hline $\mathrm{C} 101$ & sludge & 0 & 1 & \begin{tabular}{|l|}
38.2 \\
\end{tabular} & 21.9 & 21.5 & 17.1 & 49.7 & 0.1 \\
\hline$\overline{\mathrm{C} 102}$ & sludge & 0 & 0 & 44.7 & 24 & 23.3 & 23.6 & 45.9 & 2 \\
\hline C103 & sludge & 0 & 0 & \begin{tabular}{|l|}
44.7 \\
\end{tabular} & 24 & 23.3 & 23.6 & 45.9 & 2 \\
\hline
\end{tabular}




\begin{tabular}{|c|c|c|c|c|c|c|c|c|c|}
\hline \multirow[b]{2}{*}{ Tank } & \multirow[b]{2}{*}{ 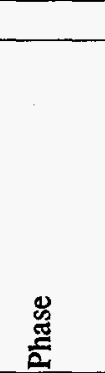 } & \multirow[b]{2}{*}{$\begin{array}{l}\text { Number } \\
\text { of } \\
\text { Samples } \\
\text { for Tank } \\
\text { Waste }\end{array}$} & \multirow[b]{2}{*}{$\begin{array}{l}\text { Number } \\
\text { of } \\
\text { Samples } \\
\text { in } \\
\text { SORWT } \\
\text { Group }\end{array}$} & \multicolumn{3}{|c|}{ Tank Median Estimate } & \multicolumn{3}{|c|}{ Worst $5 \%$ of the Waste } \\
\hline & & & & \begin{tabular}{|l|} 
Tank \\
Median \\
Estimate \\
of \\
Moisture \\
$\%$ \\
\end{tabular} & \begin{tabular}{|l|} 
\\
Relative \\
Standard \\
Deviation on \\
Median \\
\end{tabular} & \begin{tabular}{|l|}
$95 \%$ \\
Confidence \\
Bound on \\
Tank \\
Moisture \\
Estimate \\
wt\% TOC \\
(wet) \\
\end{tabular} & $\begin{array}{l}\text { Estimate } \\
\text { of Worst } \\
5 \% \text { of } \\
\text { Waste, } \\
\text { Moisture } \\
\end{array}$ & $\begin{array}{l}\text { Relative } \\
\text { Standard } \\
\text { Deviation on } \\
\text { Worst } 5 \% \text { of } \\
\text { the Waste } \\
\end{array}$ & $\begin{array}{l}95 \% \\
\text { Confidence } \\
\text { Bound on } \\
\text { Worst } 5 \% \text { of } \\
\text { the Waste } \\
\end{array}$ \\
\hline $\mathrm{C} 104$ & sludge & 0 & 0 & $\begin{array}{r}44.7 \\
\end{array}$ & 24 & 23.3 & 23.6 & $\begin{array}{r}45.9 \\
\end{array}$ & 2 \\
\hline $\mathrm{C} 105$ & sludge & 0 & 0 & 44.7 & 24 & 23.3 & 23.6 & 45.9 & 2 \\
\hline C106 & sludge & 0 & 0 & 44.7 & 24 & 23.3 & 23.6 & 45.9 & 2 \\
\hline $\mathrm{C} 107$ & sludge & 0 & 0 & 44.7 & 24 & 23.3 & 23.6 & 45.9 & 2 \\
\hline C108 & sludge & 0 & 31 & 48.2 & 4.7 & 43.7 & 27.1 & 10 & 21.6 \\
\hline C109 & sludge & 0 & 31 & 48.2 & 4.7 & 43.7 & 27.1 & 10 & 21.6 \\
\hline $\mathrm{C} 110$ & sludge & 0 & 15 & 49.5 & 6.4 & 43.1 & 28.3 & 12.3 & 21.3 \\
\hline C111 & sludge & 0 & 31 & 48.2 & 4.7 & 43.7) & 27.1 & 10 & 21.6 \\
\hline C112 & sludge & 13 & 31 & 48.2 & 4.7 & 43.7 & 27.1 & 10 & 21.6 \\
\hline $\mathrm{C} 201$ & sludge & 1 & 2 & 59.8 & 11.7 & 45.8 & 38.7 & 18.5 & 24.4 \\
\hline $\mathrm{C} 202$ & sludge & 0 & 2 & 59.8 & 11.7 & 45.8 & 38.7 & 18.5 & 24.4 \\
\hline $\mathrm{C} 203$ & sludge & 0 & 2 & 59.8 & 11.7 & 45.8 & 38.7 & 18.5 & 24.4 \\
\hline C204 & sludge & 1 & 2 & 59.8 & 11.7 & 45.8 & 38.7 & 18.5 & 24.4 \\
\hline S101 & sludge & 0 & 2 & 42.4 & 16.5 & 28.4 & 21.3 & 33.7 & 7 \\
\hline $\mathbf{S 1 0 2}$ & sludge & 0 & 2 & 42.4 & 16.5 & 28.4 & 21.3 & 33.7 & 7 \\
\hline$S 103$ & sludge & 0 & 2 & 42.4 & 16.5 & 28.4 & 21.3 & 33.7 & 7 \\
\hline$\$ 104$ & sludge & 0 & 0 & 44.7 & 24 & 23.3 & 23.6 & 45.9 & 2 \\
\hline$S 105$ & sludge & 0 & 2 & 42.4 & 16.5 & 28.4 & 21.3 & 33.7 & 7 \\
\hline S106 & sludge & 0 & 2 & 42.4 & 16.5 & 28.4 & 21.3 & 33.7 & 7 \\
\hline 5107 & sludge & 0 & 2 & 42.4 & 16.5 & 28.4 & 21.3 & 33.7 & 7 \\
\hline S108 & sludge & 0 & 2 & 42.4 & 16.5 & 28.4 & 21.3 & 33.7 & 7 \\
\hline$\$ 109$ & sludge & 0 & 2 & 42.4 & 16.5 & 28.4 & 21.3 & 33.7 & 7 \\
\hline$\$ 110$ & sludge & 0 & 2 & 42.4 & 16.5 & 28.4 & 21.3 & 33.7 & 7 \\
\hline S111 & sludge & 0 & 2 & 42.4 & 16.5 & 28.4 & 21.3 & 33.7 & 7 \\
\hline$\$ 112$ & sludge & 0 & 2 & 42.4 & 16.5 & 28.4 & 21.3 & 33.7 & 7 \\
\hline SX101 & sludge & 0 & 2 & 42.4 & 16.5 & 28.4 & 21.3 & 33.7 & 7 \\
\hline$S \times 102$ & sludge & 0 & 2 & 42.4 & 16.5 & 28.4 & 21.3 & 33.7 & 7 \\
\hline SX103 & sludge & 0 & 2 & 42.4 & 16.5 & 28.4 & 21.3 & 33.7 & 7 \\
\hline SX104 & sludge & 0 & 2 & 42.4 & 16.5 & 28.4 & 21.3 & 33.7 & 7 \\
\hline SX105 & sludge & 0 & 2 & 42.4 & 16.5 & 28.4 & 21.3 & 33.7 & 7 \\
\hline SX106 & sludge & 1 & 2 & 42.4 & 16.5 & 28.4 & 21.3 & 33.7 & 7 \\
\hline SX107 & sludge & 0 & 0 & 44.7 & 24 & 23.3 & 23.6 & 45.9 & 2 \\
\hline SX108 & sludge & 0 & 0 & 44.7 & 24 & 23.3 & 23.6 & 45.9 & 2 \\
\hline SX109 & sludge & 0 & 0 & 44.7 & 24 & 23.3 & 23.6 & 45.9 & 2 \\
\hline $\mathbf{S X 1 1 0}$ & sludge & 0 & 0 & 44.7 & 24 & 23.3 & 23.6 & 45.9 & 2 \\
\hline SX111 & sludge & 0 & 0 & 44.7 & 24 & 23.3 & 23.6 & 45.9 & 2 \\
\hline SX112 & sludge & 0 & 0 & 44.7 & 24 & 23.3 & 23.6 & 45.9 & 2 \\
\hline SX113 & sludge & 0 & 0 & 44.7 & 24 & 23.3 & 23.6 & 45.9 & 2 \\
\hline SX114 & sludge & 0 & 0 & 44.7 & 24 & 23.3 & 23.6 & 45.9 & 2 \\
\hline SX115 & sludge & 0 & 0 & 44.7 . & 24 & 23.3 & 23.6 & 45.9 & 2 \\
\hline $\mathrm{T101}$ & sludge & 0 & 0 & 44.7 & 24 & 23.3 & 23.6 & 45.9 & 2 \\
\hline
\end{tabular}




\begin{tabular}{|c|c|c|c|c|c|c|c|c|c|}
\hline \multirow[b]{2}{*}{ Tank } & \multirow[b]{2}{*}{$\begin{array}{l}\text { 岕 } \\
\text { 胥 }\end{array}$} & \multirow[b]{2}{*}{$\begin{array}{l}\text { Number } \\
\text { of } \\
\text { Samples } \\
\text { for Tank } \\
\text { Waste }\end{array}$} & \multirow[b]{2}{*}{$\begin{array}{l}\text { Number } \\
\text { of } \\
\text { Samples } \\
\text { in } \\
\text { SORWT } \\
\text { Group }\end{array}$} & \multicolumn{3}{|c|}{ Tank Median Estimate } & \multicolumn{3}{|c|}{ Worst $5 \%$ of the Waste } \\
\hline & & & & $\begin{array}{l}\text { Tank } \\
\text { Median } \\
\text { Estimate } \\
\text { of } \\
\text { Moisture } \\
\%\end{array}$ & $\begin{array}{l}\text { Relative } \\
\text { Standard } \\
\text { Deviation on } \\
\text { Median }\end{array}$ & \begin{tabular}{|l|}
$95 \%$ \\
Confidence \\
Bound on \\
Tank \\
Moisture \\
Estimate \\
wt\% TOC \\
(wet)
\end{tabular} & $\begin{array}{l}\text { Estimate } \\
\text { of Worst } \\
5 \% \text { of } \\
\text { Waste, } \\
\text { Moisture }\end{array}$ & $\begin{array}{l}\text { Relative } \\
\text { Standard } \\
\text { Deviation on } \\
\text { Worst } 5 \% \text { of } \\
\text { the Waste }\end{array}$ & $\begin{array}{l}95 \% \\
\text { Confidence } \\
\text { Bound on } \\
\text { Worst } 5 \% \text { of } \\
\text { the Waste }\end{array}$ \\
\hline T102 & sludge & 0 & 0 & 44.7 & 24 & 23.3 & 23.6 & 45.9 & 2 \\
\hline T103 & sludge & 0 & 0 & 44.7 & 24 & 23.3 & 23.6 & 45.9 & 2 \\
\hline T104 & sludge & 2 & 2 & 55 & 12.7 & 41 & 33.9 & 21.2 & 19.5 \\
\hline T105. & sludge & 0 & 45 & 35.9 & 5.2 & 32.2 & 14.8 & 16.3 & 10 \\
\hline T106 & sludge & 1 & 45 & 35.9 & 5.2 & 32.2 & 14.8 & 16.3 & 10 \\
\hline T107 & sludge & 18 & 31 & 48.2 & 4.7 & 43.7 & 27.1 & 10 & 21.6 \\
\hline T108 & sludge & 0 & 15 & 49.5 & 6.4 & 43.1 & 28.3 & 12.3 & 21.3 \\
\hline T109 & sludge & 0 & 0 & 44.7 & 24 & 23.3 & 23.6 & 45.9 & 2 \\
\hline T110 & sludge & 0 & 0 & 44.7 & 24 & 23.3 & 23.6 & 45.9 & 2 \\
\hline T111 & sludge & 0 & 0 & 44.7 & 24 & 23.3 & 23.6 & 45.9 & 2 \\
\hline T112 & sludge & 0 & 0 & 44.7 & 24 & 23.3 & 23.6 & 45.9 & 2 \\
\hline T201 & sludge & 0 & 7 & 64.9 & 6.8 & 56 & 43.8 & 10.7 & 34.4 \\
\hline T202 & sludge & 0 & 7 & 64.9 & 6.8 & 56 & \begin{tabular}{|l|l|}
43.8 \\
\end{tabular} & 10.7 & 34.4 \\
\hline T203 & sludge & 0 & 7 & 64.9 & 6.8 & 56 & 43.8 & 10.7 & 34.4 \\
\hline T204 & sludge & 1 & 7 & 64.9 & 6.8 & 56 & 43.8 & 10.7 & 34.4 \\
\hline TX101 & sludge & 0 & 0 & 44.7 & 24 & 23.3 & 23.6 & 45.9 & 2 \\
\hline TX103 & sludge & 0 & 0 & 44.7 & 24 & 23.3 & 23.6 & 45.9 & 2 \\
\hline TY101 & sludge & 2 & 2 & 44 & 15.9 & 30 & 22.9 & 31.3 & 8.6 \\
\hline TY103 & sludge & 2 & 5 & 51 & 9.9 & 40.9 & 29.9 & 17.7 & 19.3 \\
\hline TY104 & sludge & 3 & 5 & 51 & 9.9 & 40.9 & 29.9 & 17.7 & 19.3 \\
\hline TY105 & sludge & 1 & 4 & 40 & 13.8 & 28.9 & 18.9 & 30.4 & 7.4 \\
\hline TY106 & sludge & 3 & 4 & 40 & 13.8 & 28.9 & 18.9 & 30.4 & 7.4 \\
\hline U101 & sludge & 0 & 0 & 44.7 & 24 & 23.3 & 23.6 & 45.9 & 2 \\
\hline U102 & sludge & 0 & 1 & 29.8 & 28.1 & 13 & \begin{tabular}{|l|}
8.7 \\
\end{tabular} & 98.2 & $\overline{0}$ \\
\hline U103 & sludge & 1 & 1 & 29.8 & 28.1 & 13 & 8.7 & 98.2 & 0 \\
\hline U104 & sludge & 0 & 0 & 44.7 & 24 & 23.3 & 23.6 & 45.9 & 2 \\
\hline U105 & sludge & 0 & 3 & 45.6 & 13.5 & 33.3 & 24.5 & 25.8 & 11.8 \\
\hline U106 & sludge & 0 & 1 & 29.8 & 28.1 & 13 & 8.7 & 98.2 & 0 \\
\hline U107 & sludge & 1 & 3 & 45.6 & 13.5 & 33.3 & 24.5 & 25.8 & 11.8 \\
\hline U108 & sludge & 1 & 3 & 45.6 & 13.5 & 33.3 & 24.5 & 25.8 & 11.8 \\
\hline U109 & sludge & 1 & 3 & 45.6 & 13.5 & 33.3 & 24.5 & 25.8 & 11.8 \\
\hline U110 & sludge & 44 & 45 & 35.9 & 5.2 & 32.2 & 14.8 & 16.3 & 10 \\
\hline U111. & sludge & 0 & 1 & 29.8 & 28.1 & 13 & 8.7 & 98.2 & 0 \\
\hline U112 & sludge & 0 & 0 & 44.7 & 24 & 23.3 & 23.6 & 45.9 & 2 \\
\hline U201 & sludge & 0 & 0 & 44.7 & 24 & 23.3 & 23.6 & 45.9 & 2 \\
\hline U202 & sludge & 0 & 0 & 44.7 & 24 & 23.3 & 23.6 & 45.9 & 2 \\
\hline $\mathrm{U} 203$ & sludge & 0 & 0 & 44.7 & 24 & 23.3 & 23.6 & 45.9 & 2 \\
\hline U204 & sludge & 1 & 1 & 37 & 22.7 & 20.2 & 15.9 & 53.7 & 0 \\
\hline
\end{tabular}


Appendix $\mathbf{H}$

Total Organic Carbon Data not Included in ANOVA Estimates 


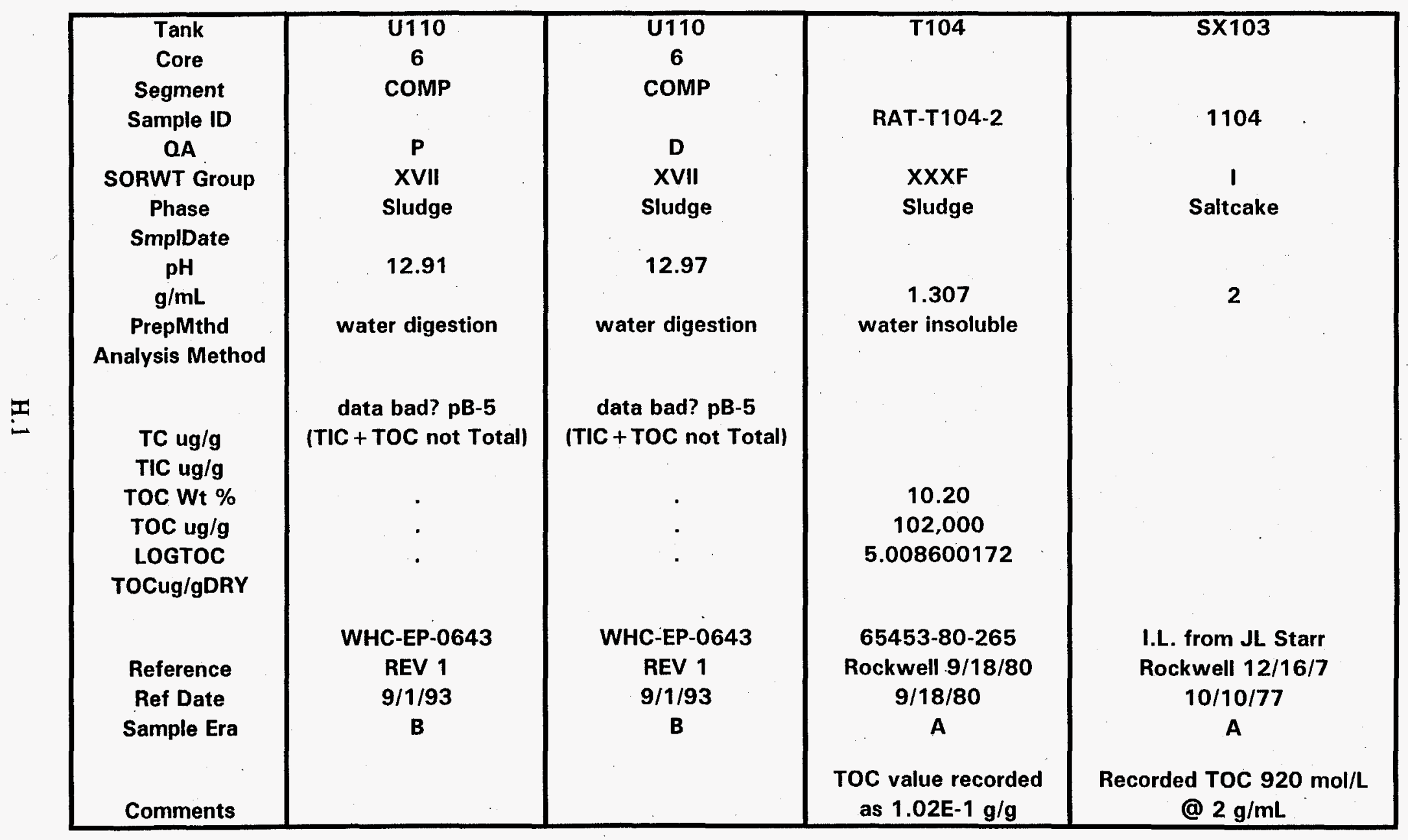




\section{Appendix I}

Single-Shell Tank Safety Criteria Exceedance Probability 
Exceedance Probabilities

\begin{tabular}{|c|c|c|c|c|c|c|c|}
\hline \multirow[b]{2}{*}{ Tank } & \multirow[b]{2}{*}{ phase } & \multicolumn{2}{|c|}{ Median } & \multirow{2}{*}{$\begin{array}{l}\text { Exceed. } \\
\text { Prob. }\end{array}$} & \multicolumn{2}{|c|}{ Worst $5 \%$} & \multirow{2}{*}{$\begin{array}{c}\text { Exceed. } \\
\text { Prob. }\end{array}$} \\
\hline & & $\%$ TOC & $\% \mathrm{H} 2 \mathrm{O}$ & & $\% \mathrm{TOC}$ & $\% \mathrm{H} 2 \mathrm{O}$ & \\
\hline A101 & liq & 0.9 & 50.4 & 0 & 3.8 & 34.7 & 0.0 \\
\hline A101 & salt & 0.6 & 39.1 & 0 & 4.5 & 28.2 & 0.3 \\
\hline A101 & sludge & 0.6 & 39.5 & 0 & 2.4 & 18.4 & 7.1 \\
\hline $\mathrm{A} 102$ & $\operatorname{liq}$ & 0.4 & 48.2 & 0 & 1.6 & 32.5 & 0.0 \\
\hline A 102 & salt & 0.6 & 43.1 & 0 & 4.5 & 31.0 & 1.0 \\
\hline A102 & sludge & 0.6 & 39.5 & 0 & 2.5 & 18.4 & 5.8 \\
\hline A103 & $\operatorname{liq}$ & 0.6 & 52.0 & 0 & 2.5 & 36.4 & 0.0 \\
\hline A103 & salt & $\mathrm{NA}$ & $\mathrm{NA}$ & NA & NA & NA & NA \\
\hline A103 & sludge & 0.7 & 39.5 & 0 & 2.6 & 18.4 & 6.3 \\
\hline $\mathrm{A} 104$ & liq & $\mathrm{NA}$ & $\mathrm{NA}$ & NA & $\mathrm{NA}$ & NA & $\mathrm{NA}$ \\
\hline A104 & salt & NA & NA & NA & NA & NA & NA \\
\hline A104 & sludge & 0.1 & 44.7 & 0 & 0.6 & 23.6 & 1.4 \\
\hline A105 & liq & 0.3 & 65.0 & 0 & 1.1 & 49.3 & 0.1 \\
\hline A105 & salt & NA & $\mathrm{NA}$ & $\mathrm{NA}$ & $\mathrm{NA}$ & NA & NA \\
\hline $\mathrm{A} 105$ & sludge & 0.1 & 44.7 & 0 & 0.6 & 23.6 & 1.4 \\
\hline A106 & liq & 0.1 & 54.6 & 0 & 27.4 & 38.9 & 0.1 \\
\hline A106 & salt & NA & NA & $\mathrm{NA}$ & $\mathrm{NA}$ & $\mathrm{NA}$ & NA \\
\hline A106 & sludge & 0.5 & $4 \dot{4} .3$ & 0 & 1.9 & 23.2 & 1.4 \\
\hline AX101 & liq & 0.8 & 47.1 & 0 & 3.0 & 31.5 & 0.0 \\
\hline AX101 & salt & 0.6 & 43.1 & 0 & 4.5 & 31.0 & 1.0 \\
\hline AX101 & sludge & 0.5 & 39.5 & 0 & 2.1 & 18.4 & 8.6 \\
\hline $\mathrm{AX} 102$ & liq & 1.1 & 60.0 & 0 & 4.4 & 44.3 & 1.1 \\
\hline AX102 & salt & 0.6 & 43.1 & 0 & 4.3 & 31.0 & 0.9 \\
\hline AX102 & sludge & 0.1 & 44.7 & 0 & 0.6 & 23.6 & 1.4 \\
\hline AX103 & $\mathrm{liq}$ & 0.8 & 53.1 & 0 & 3.3 & 37.4 & 0.2 \\
\hline AX103 & salt & 0.6 & 43.1 & 0 & 4.3 & 31.0 & 0.9 \\
\hline AX103 & sludge & 0.1 & 44.7 & 0 & 0.6 & 23.6 & 1.4 \\
\hline AX104 & liq & $\mathrm{NA}$ & NA & $\mathrm{NA}$ & NA & NA & NA \\
\hline AX104 & salt & $\mathrm{NA}$ & $\mathrm{NA}$ & NA & NA & $\mathrm{NA}$ & NA \\
\hline AX104 & sludge & 0.1 & 44.7 & 0 & 0.6 & 23.6 & 1.4 \\
\hline B101 & liq & 0.3 & 68.9 & 0 & 1.1 & 53.2 & 0.0 \\
\hline B101 & salt & NA & $\mathrm{NA}$ & $\mathrm{NA}$ & NA & $\mathrm{NA}$ & NA \\
\hline B101 & sludge & 0.1 & 34.5 & 0 & 0.6 & 13.4 & 3.3 \\
\hline B102 & liq & 0.3 & 65.6 & 0 & 1.1 & 49.9 & 0.0 \\
\hline B102 & salt & 0.6 & 43.1 & 0 & 4.3 & 31.0 & 0.9 \\
\hline B102 & sludge & 0.1 & 34.5 & 0 & 0.6 & 13.4 & 3.3 \\
\hline B103 & $\operatorname{liq}$ & NA & $\mathrm{NA}$ & NA & NA & $\mathrm{NA}$ & $\mathrm{NA}$ \\
\hline B103 & salt & $\mathrm{NA}$ & $\mathrm{NA}$ & $\mathrm{NA}$ & NA & $\mathrm{NA}$ & $\mathrm{NA}$ \\
\hline B103 & sludge & 0.1 & 34.5 & 0 & 0.6 & 13.4 & 3.3 \\
\hline B104 & liq & 0.3 & 65.0 & 0 & 1.1 & 49.3 & 0.1 \\
\hline B104 & salt & 0.6 & 43.1 & 0 & 4.3 & 31.0 & 0.9 \\
\hline B104 & sludge & 0.1 & 44.7 & 0 & 0.6 & 23.6 & 1.4 \\
\hline
\end{tabular}




\begin{tabular}{|c|c|c|c|c|c|c|c|}
\hline \multirow[b]{2}{*}{ Tank } & \multirow[b]{2}{*}{ phase } & \multicolumn{2}{|c|}{ Median } & \multirow{2}{*}{$\begin{array}{c}\text { Exceed. } \\
\text { Prob. }\end{array}$} & \multicolumn{2}{|c|}{ Worst $5 \%$} & \multirow{2}{*}{$\begin{array}{c}\text { Exceed. } \\
\text { Prob. }\end{array}$} \\
\hline & & $\% \mathrm{TOC}$ & $\% \mathrm{H} 2 \mathrm{O}$ & & $\%$ TOC & $\% \mathrm{H} 2 \mathrm{O}$ & \\
\hline $\mathrm{B} 105$ & liq & 0.3 & 59.6 & 0 & 1.1 & 44.0 & 0.1 \\
\hline B105 & salt & 0.5 & 43.1 & 0 & 4.0 & 31.0 & 0.8 \\
\hline B105 & sludge & 0.1 & 45.1 & 0 & 0.3 & 24.0 & 0.0 \\
\hline B106 & liq & 0.2 & 71.7 & 0 & 0.8 & 56.0 & 0.0 \\
\hline B106 & salt & NA & $\mathrm{NA}$ & NA & $\mathrm{NA}$ & NA & NA \\
\hline B106 & sludge & 0.1 & 49.5 & 0 & 0.3 & 28.3 & 0.0 \\
\hline B107 & $\operatorname{liq}$ & 0.3 & 69.1 & 0 & 1.1 & 53.4 & 0.0 \\
\hline $\mathrm{B} 107$ & salt & NA & NA & NA & NA & $\mathrm{NA}$ & NA \\
\hline B107 & sludge & 0.3 & 47.8 & 0 & 1.2 & 26.7 & 0.7 \\
\hline B108 & liq & 0.3 & 69.1 & 0 & 1.1 & 53.4 & 0.0 \\
\hline B108 & salt & NA & NA & NA & $\mathrm{NA}$ & NA & NA \\
\hline B108 & sludge & 0.3 & 47.8 & 0 & 1.2 & 26.7 & 0.7 \\
\hline B109 & liq & 0.3 & 74.7 & 0 & 1.1 & 59.0 & 0.0 \\
\hline B109 & salt & NA & NA & NA & $\mathrm{NA}$ & NA & NA \\
\hline B109 & sludge & 0.3 & 47.8 & 0 & 1.2 & 26.7 & 0.7 \\
\hline B110 & liq & 0.3 & 65.0 & 0 & 1.1 & 49.3 & 0.1 \\
\hline B110 & salt & NA & NA & NA & $\mathrm{NA}$ & $\mathrm{NA}$ & $\mathrm{NA}$ \\
\hline B110 & sludge & 0.0 & 44.7 & 0 & 0.2 & 23.6 & 0.0 \\
\hline B111 & liq & 0.3 & 65.0 & 0 & 1.1 & 49.3 & 0.1 \\
\hline B111 & salt & $\mathrm{NA}$ & $\mathrm{NA}$ & $\mathrm{NA}$ & $\mathrm{NA}$ & $\mathrm{NA}$ & $\mathrm{NA}$ \\
\hline B111 & sludge & 0.1 & 44.7 & 0 & 0.4 & 23.6 & 0.0 \\
\hline B112 & liq & 0.3 & 65.0 & 0 & 1.1 & 49.3 & 0.1 \\
\hline B112 & salt & NA & NA & $\mathrm{NA}$ & NA & NA & NA \\
\hline B112 & sludge & 0.1 & 44.7 & 0 & 0.3 . & 23.6 & 0.0 \\
\hline B201 & liq & 0.3 & 65.0 & 0 & 1.1 & 49.3 & 0.1 \\
\hline B201 & salt & NA & NA & NA & NA & NA & NA \\
\hline B201 & sludge & 0.2 & 64.9 & 0 & 0.9 & 43.8 & 0.0 \\
\hline B202 & liq & 0.3 & 65.0 & 0 & 1.1 & 49.3 & 0.1 \\
\hline B202 & salt & NA & $\mathrm{NA}$ & NA & NA & NA & NA \\
\hline B202 & sludge & 0.2 & 64.9 & 0 & 7.6 & 43.8 & 0.0 \\
\hline B203 & liq & 0.3 & 65.0 & 0 & 1.1 & 49.3 & 0.1 \\
\hline $\mathrm{B} 203$ & salt & NA & NA & NA & NA & NA & NA \\
\hline B203 & sludge & 0.2 & 64.9 & 0 & 0.9 & 43.8 & 0.0 \\
\hline B204 & liq & 0.3 & 65.0 & 0 & 1.1 & 49.3 & 0.1 \\
\hline B204 & salt & NA & NA & NA & NA & NA & NA \\
\hline B204 & sludge & 0.2 & 64.9 & 0 & 0.7 & 43.8 & 0.0 \\
\hline BX101 & liq & 0.4 & 71.7 & 0 & 1.5 & 56.0 & 0.0 \\
\hline BX101 & salt & $\mathrm{NA}$ & NA & $\mathrm{NA}$ & NA & NA & NA \\
\hline BX101 & sludge & 0.2 & 38.2 & 0 & 0.9 & 17.1 & 1.4 \\
\hline BX102 & liq & 0.4 & 71.7 & 0 & 1.5 & 56.0 & 0.0 \\
\hline BX102 & salt & NA & NA & $\mathrm{NA}$ & $\mathrm{NA}$ & NA & $\mathrm{NA}$ \\
\hline BX102 & sludge & 0.2 & 38.2 & 0 & 0.9 & 17.1 & 1.4 \\
\hline $\mathrm{BX} 103$ & liq & 0.4 & 83.1 & 0 & 1.5 & 67.4 & 0.0 \\
\hline BX103 & salt & NA & $\mathrm{NA}$ & NA & NA & NA & NA \\
\hline
\end{tabular}




\begin{tabular}{|c|c|c|c|c|c|c|c|}
\hline \multirow[b]{2}{*}{ Tank } & \multirow[b]{2}{*}{ phase } & \multicolumn{2}{|c|}{ Median } & \multirow{2}{*}{$\begin{array}{c}\text { Exceed. } \\
\text { Prob. }\end{array}$} & \multicolumn{2}{|c|}{ Worst $5 \%$} & \multirow{2}{*}{$\begin{array}{c}\text { Exceed. } \\
\text { Prob. }\end{array}$} \\
\hline & & $\% \mathrm{TOC}$ & $\% \mathrm{H} 2 \mathrm{O}$ & & $\% \mathrm{TOC}$ & $\% \mathrm{H} 2 \mathrm{O}$ & \\
\hline$\overline{B X 103}$ & sludge & 0.2 & 38.2 & 0 & 0.9 & 17.1 & 1.4 \\
\hline BX104 & liq & 0.5 & 80.3 & 0 & 1.9 & 64.6 & 0.0 \\
\hline BX104 & salt & NA & NA & NA & NA & NA & NA \\
\hline BX104 & sludge & 0.3 & 38.2 & 0 & 1.0 & 17.1 & 0.0 \\
\hline BX105 & liq & 0.5 & 74.4 & 0 & 2.2 & 58.8 & 0.0 \\
\hline BX105 & salt & 0.6 & 43.1 & 0 & 4.3 & 31.0 & 0.9 \\
\hline BX105 & sludge & 0.2 & 38.2 & 0 & 1.0 & 17.1 & 0.1 \\
\hline BX106 & liq & 0.4 & 64.3 & 0 & 1.4 & 48.7 & 0.0 \\
\hline BX106 & salt & $\mathrm{NA}$ & NA & NA & NA & NA & NA \\
\hline BX106 & sludge & 0.2 & 38.2 & 0 & 0.9 & 17.1 & 1.4 \\
\hline BX107 & liq & 0.2 & 70.5 & 0 & 0.8 & 54.8 & 0.0 \\
\hline BX107 & salt & $\mathrm{NA}$ & NA & NA & $\mathrm{NA}$ & NA & NA \\
\hline BX107 & sludge & 0.1 & 49.5 & 0 & 0.3 & 28.3 & 0.0 \\
\hline BX108 & liq & 0.4 & 71.7 & 0 & 1.5 & 56.0 & 0.0 \\
\hline BX108 & salt & NA & NA & $\mathrm{NA}$ & NA & $\mathrm{NA}$ & $\mathrm{NA}$ \\
\hline BX108 & sludge & 0.2 & 38.2 & 0 & 0.9 & 17.1 & 1.4 \\
\hline BX109 & liq & 0.3 & 65.4 & 0 & 1.2 & 49.7 & 0.0 \\
\hline BX109 & salt & $\mathrm{NA}$ & $\mathrm{NA}$ & NA & NA & NA & NA \\
\hline BX109 & sludge & 0.2 & 38.2 & 0 & 0.9 & 17.1 & 1.4 \\
\hline BX110 & liq & 0.3 & 61.7 & 0 & 1.4 & 46.1 & 0.0 \\
\hline BX110 & salt & 0.6 & 48.4 & 0 & 4.3 & 34.8 & 0.0 \\
\hline BX110 & sludge & 0.0 & 48.9 & 0 & 0.2 & 27.8 & 0.0 \\
\hline BX111 & liq & NA & $\mathrm{NA}$ & NA & $\mathrm{NA}$ & NA & NA \\
\hline BX111 & salt & 0.6 & 43.1 & 0 & 4.3 & 31.0 & 0.9 \\
\hline BX111 & sludge & 0.1 & 48.9 & 0 & 0.2 & 27.8 & 0.0 \\
\hline BX112 & liq & 0.3 & 69.1 & 0 & 1.2 & 53.4 & 0.0 \\
\hline BX112 & salt & NA & NA & $\mathrm{NA}$ & $\mathrm{NA}$ & NA & NA \\
\hline BX112 & sludge & 0.4 & 47.8 & 0 & 1.6 & 26.7 & 0.1 \\
\hline BY101 & liq & 0.2 & 58.0 & 0 & 1.0 & 42.3 & 0.1 \\
\hline BY101 & salt & 0.7 & 16.9 & 0 & 5.1 & 12.2 & 33.1 \\
\hline BY101 & sludge & 0.1 & 37.9 & 0 & 0.6 & 16.8 & 2.5 \\
\hline BY102 & liq & 0.2 & 57.3 & 0 & 0.7 & 41.6 & 0.0 \\
\hline BY102 & salt & 0.6 & 43.1 & 0 & 4.3 & 31.0 & 0.9 \\
\hline BY102 & sludge & $\mathrm{NA}$ & NA & $\mathrm{NA}$ & NA & NA & NA \\
\hline BY103 & liq & 0.2 & 54.8 & 0 & 0.9 & 39.1 & 0.0 \\
\hline BY103 & salt & 0.7 & 43.1 & 0 & 5.1 & 31.0 & 1.2 \\
\hline BY103 & sludge & 0.1 & 37.9 & 0 & 0.6 & 16.8 & 2.5 \\
\hline BY104 & liq & 0.2 & 58.0 & 0 & 1.0 & 42.3 & 0.1 \\
\hline BY104 & salt & 0.7 & 16.1 & 0 & 5.1 & 11.6 & 36.5 \\
\hline BY104 & sludge & 0.1 & 37.9 & 0 & 0.6 & 16.8 & 2.5 \\
\hline BY105 & liq & 0.2 & 55.9 & 0 & 0.9 & 40.2 & 0.0 \\
\hline BY105 & salt & 0.7 & 43.1 . & 0 & 5.1 & 31.0 & 1.2 \\
\hline BY105 & sludge & 0.1 & 37.9 & 0 & 0.6 & 16.8 & 2.5 \\
\hline BY106 & liq & 0.2 & 53.8 & 0 & 0.9 & 38.1 & 0.0 \\
\hline
\end{tabular}




\begin{tabular}{|c|c|c|c|c|c|c|c|}
\hline \multirow[b]{2}{*}{ Tank } & \multirow[b]{2}{*}{ phase } & \multicolumn{2}{|c|}{ Median } & \multirow{2}{*}{$\begin{array}{c}\text { Exceed. } \\
\text { Prob. }\end{array}$} & \multicolumn{2}{|c|}{ Worst $5 \%$} & \multirow{2}{*}{$\begin{array}{c}\text { Exceed. } \\
\text { Prob. }\end{array}$} \\
\hline & & $\% \mathrm{TOC}$ & $\% \mathrm{H} 2 \mathrm{O}$ & & $\% \mathrm{TOC}$ & $\% \mathrm{H} 2 \mathrm{O}$ & \\
\hline$\overline{B Y 106}$ & salt & 0.7 & 43.1 & 0 & 5.1 & 31.0 & 1.2 \\
\hline BY106 & sludge & 0.1 & 37.9 & 0 & 0.6 & 16.8 & 2.5 \\
\hline BY107 & $\mathrm{liq}$ & 0.3 & 58.0 & 0 & 1.1 & 42.3 & 0.0 \\
\hline BY107 & salt & 0.7 & 16.9 & 0 & 5.1 & 12.2 & 33.1 \\
\hline BY107 & sludge & 0.1 & 37.9 & 0 & 0.6 & 16.8 & 2.5 \\
\hline BY108 & $\operatorname{liq}$ & 0.2 & 58.0 & 0 & 1.0 & 42.3 & 0.1 \\
\hline BY108 & salt & 0.7 & 16.9 & 0 & 5.1 & 12.2 & 33.1 \\
\hline BY108 & sludge & 0.1 & 37.9 & 0 & 0.6 & 16.8 & 2.5 \\
\hline BY109 & liq & 0.3 & 59.4 & 0 & 1.2 & 43.8 & 0.0 \\
\hline BY109 & salt & 0.6 & 43.1 & 0 & 4.3 & 31.0 & 0.9 \\
\hline BY109 & sludge & 0.1 & 44.7 & 0 & 0.6 & 23.6 & 1.4 \\
\hline BY110 & liq. & 0.2 & 58.0 & 0 & 1.0 & 42.3 & 0.1 \\
\hline BY110 & salt & 0.7 & $16.9^{\circ}$ & 0 & 5.1 & 12.2 & 33.1 \\
\hline BY110 & sludge & 0.1 & 37.9 & 0 & 0.6 & 16.8 & 2.5 \\
\hline BY111 & liq & $\mathrm{NA}$ & NA & NA & NA & NA & NA \\
\hline BY111 & salt & 0.7 & 16.9 & 0 & 5.1 & 12.2 & 33.1 \\
\hline BY111 & sludge & 0.1 & 37.9 & 0 & 0.6 & 16.8 & 2.5 \\
\hline BY112 & liq & 0.2 & 58.0 & 0 & 1.0 & 42.3 & 0.1 \\
\hline BY112 & salt & 0.7 & 16.9 & 0 & 5.1 & 12.2 & 33.1 \\
\hline BY112 & sludge & 0.1 & 37.9 & 0 & 0.6 & 16.8 & 2.5 \\
\hline C101 & $\mathrm{liq}$ & 0.4 & 71.7 & 0 & 1.5 & 56.0 & 0.0 \\
\hline C101 & salt & $\mathrm{NA}$ & $\mathrm{NA}$ & NA & NA & NA & $\mathrm{NA}$ \\
\hline C101 & sludge & 0.2 & 38.2 & 0 & 0.9 & 17.1 & 1.4 \\
\hline C102 & liq & 0.3 & 65.0 & 0 & 1.1 & 49.3 & 0.0 \\
\hline C102 & salt & NA & $\mathrm{NA}$ & $\mathrm{NA}$ & NA & NA & NA \\
\hline C102 & sludge & 0.1 & 44.7 & 0 & 0.6 & 23.6 & 1.4 \\
\hline $\mathrm{C} 103$ & $\mathrm{liq}$ & 0.6 & 80.1 & 0 & 2.3 & 64.4 & 0.0 \\
\hline C103 & salt & $\mathrm{NA}$ & NA & $\mathrm{NA}$ & $\mathrm{NA}$ & NA & $\mathrm{NA}$ \\
\hline C103 & sludge & 0.3 & 44.7 & 0 & 1.0 & 23.6 & 0.1 \\
\hline C104 & liq & 0.5 & 72.7 & 0 & 2.0 & 57.0 & 0.0 \\
\hline C104 & salt & $\mathrm{NA}$ & $\mathrm{NA}$ & $\mathrm{NA}$ & $\mathrm{NA}$ & $\mathrm{NA}$ & NA \\
\hline C104 & sludge & 0.3 & 44.7 & 0 & 1.2 & 23.6 & 1.1 \\
\hline C105 & liq & 0.3 & 65.0 & 0 & 1.0 & 49.3 & $0: 0$ \\
\hline C105 & salt & $\mathrm{NA}$ & $\mathrm{NA}$ & NA & NA & NA & NA \\
\hline C105 & sludge & 0.1 & 44.7 & 0 & 0.4 & 23.6 & 0.0 \\
\hline C106 & liq & 0.3 & 71.4 & 0 & 1.1 & 55.7 & 0.0 \\
\hline C106 & salt & NA & $\mathrm{NA}$ & NA & NA & NA & NA \\
\hline C106 & sludge & 0.2 & 44.7 & 0 & 0.8 & 23.6 & 0.0 \\
\hline C107 & $\operatorname{liq}$ & 0.2 & 65.0 & 0 & 0.6 & 49.3 & 0.0 \\
\hline C107 & salt & $\mathrm{NA}$ & $\mathrm{NA}$ & NA & NA & NA & NA \\
\hline C107 & sludge & 0.1 & 44.7 & 0 & 0.6 & 23.6 & 1.4 \\
\hline C108 & liq & $\mathrm{NA}$ & NA & NA & NA & NA & NA \\
\hline $\mathrm{C} 108$ & salt & $\mathrm{NA}$ & $\mathrm{NA}$ & NA & NA & $\mathrm{NA}$ & NA \\
\hline C108 & sludge & 0.2 & 48.2 & 0 & 0.7 & 27.1 & 0.0 \\
\hline
\end{tabular}




\begin{tabular}{|c|c|c|c|c|c|c|c|}
\hline \multirow[b]{2}{*}{ Tank } & \multirow[b]{2}{*}{ phase } & \multicolumn{2}{|c|}{ Median } & \multirow{2}{*}{$\begin{array}{c}\text { Exceed. } \\
\text { Prob. }\end{array}$} & \multicolumn{2}{|c|}{ Worst $5 \%$} & \multirow{2}{*}{$\begin{array}{c}\text { Exceed. } \\
\text { Prob. }\end{array}$} \\
\hline & & $\%$ TOC & $\% \mathrm{H} 2 \mathrm{O}$ & & $\%$ TOC & $\% \mathrm{H} 2 \mathrm{O}$ & \\
\hline C109 & $\mathrm{liq}$ & 0.2 & 72.2 & 0 & 0.7 & 56.5 & 0.0 \\
\hline C109 & salt & $\mathrm{NA}$ & NA & NA & $\mathrm{NA}$ & NA & NA \\
\hline C109 & sludge & 0.2 & 48.2 & 0 & 1.0 & 27.1 & 0.0 \\
\hline C110 & $\operatorname{liq}$ & 0.1 & 72.9 & 0 & 0.5 & 57.2 & 0.0 \\
\hline C110 & salt & NA & NA & NA & NA & NA & NA \\
\hline C110 & sludge & 0.1 & 49.5 & 0 & 0.3 & 28.3 & 0.0 \\
\hline C111 & liq & $\mathrm{NA}$ & $\mathrm{NA}$ & NA & NA & NA & NA \\
\hline C111 & salt & NA & NA & NA & NA & NA & NA \\
\hline C111 & sludge & 0.2 & 48.2 & 0 & 0.7 & 27.1 & 0.0 \\
\hline $\mathrm{C} 112$ & liq & 0.2 & 60.7 & 0 & 0.7 & 45.0 & 0.0 \\
\hline C112 & salt & NA & NA & NA & NA. & NA & NA \\
\hline C112 & sludge & 0.3 & 48.2 & 0 & 1.2 & 27.1 & 0.0 \\
\hline $\mathrm{C} 201$ & liq & NA & $\mathrm{NA}$ & NA & NA & $\mathrm{NA}$ & NA \\
\hline $\mathrm{C} 201$ & salt & $\mathrm{NA}$ & NA & NA & NA & NA & NA \\
\hline $\mathrm{C} 201$ & sludge & 0.2 & 59.8 & 0 & 0.7 & 38.7 & 0.0 \\
\hline $\mathrm{C} 202$ & $\mathrm{liq}$ & NA & NA & NA & NA & NA & $\mathrm{NA}$ \\
\hline $\mathrm{C} 202$ & salt & $\mathrm{NA}$ & $\mathrm{NA}$ & $\mathrm{NA}$ & NA & NA & $\mathrm{NA}$ \\
\hline $\mathrm{C} 202$ & sludge & 0.2 & 59.8 & 0 & 0.7 & 38.7 & 0.0 \\
\hline C203 & liq & $\mathrm{NA}$ & NA & NA & NA & $\mathrm{NA}$ & NA \\
\hline $\mathrm{C} 203$ & salt & NA & NA & NA & $\mathrm{NA}$ & NA & NA \\
\hline C203 & sludge & 0.2 & 59.8 & 0 & 0.7 & 38.7 & 0.0 \\
\hline $\mathrm{C} 204$ & liq & $\mathrm{NA}$ & $\mathrm{NA}$ & $\mathrm{NA}$ & $\mathrm{NA}$ & $\mathrm{NA}$ & $\mathrm{NA}$ \\
\hline C204 & salt & NA & NA & NA & $\mathrm{NA}$ & NA & NA \\
\hline C204 & sludge & 0.2 & 59.8 & 0 & 0.7 & 38.7 & 0.0 \\
\hline$\$ 101$ & liq & 0.5 & 71.5 & 0 & 1.9 & 55.8 & 0.0 \\
\hline $\mathrm{S} 101$ & salt & 0.4 & 21.6 & 0 & 3.3 & 15.5 & 9.6 \\
\hline S101 & sludge & 0.1 & 42.4 & 0 & 0.6 & 21.3 & 1.4 \\
\hline S102 & liq & 0.9 & 60.7 & 0 & 3.5 & 45.0 & 0.0 \\
\hline $\mathrm{S} 102$ & salt & 0.4 & 21.6 & 0 & 3.3 & 15.5 & 9.6 \\
\hline S102 & sludge & 0.1 & 42.4 & 0 & 0.6 & 21.3 & 1.4 \\
\hline S103 & liq & 0.5 & 59.7 & 0 & 1.9 & 44.0 & 0.1 \\
\hline S103 & salt & 0.4 & 21.6 & 0 & 3.3 & 15.5 & 9.6 \\
\hline S103 & sludge & 0.1 & 42.4 & 0 & 0.6 & 21.3 & 1.4 \\
\hline S104 & liq & 0.3 & 66.2 & 0 & 1.2 & 50.5 & 0.0 \\
\hline S104 & salt & $\mathrm{NA}$ & $\mathrm{NA}$ & $\mathrm{NA}$ & $\mathrm{NA}$ & $\mathrm{NA}$ & $\mathrm{NA}$ \\
\hline S104 & sludge & 0.2 & 44.7 & 0 & 0.6 & 23.6 & 0.0 \\
\hline S105 & liq & 0.5 & 54.0 & 0 & 1.9 & 38.3 & 0.1 \\
\hline S105 & salt & 0.4 & 8.5 & 0 & 3.3 & 6.1 & 28.1 \\
\hline S105 & sludge & 0.1 & 42.4 & 0 & 0.6 & 21.3 & 1.4 \\
\hline $\mathrm{S} 106$ & liq & 0.5 & 52.8 & 0 & 1.9 & 37.1 & 0.1 \\
\hline S106 & salt & 0.4 & 21.6 & 0 & 3.3 & 15.5 & 9.6 \\
\hline S106 & sludge & 0.1 & 42.4 & 0 & 0.6 & 21.3 & 1.4 \\
\hline S107 & liq & 0.5 & 52.6 & 0 & 2.0 & 36.9 & 0.0 \\
\hline S107 & salt & 0.4 & 21.6 & 0 & 3.3 & 15.5 & 9.6 \\
\hline
\end{tabular}




\begin{tabular}{|c|c|c|c|c|c|c|c|}
\hline \multirow[b]{2}{*}{ Tank } & \multirow[b]{2}{*}{ phase } & \multicolumn{2}{|c|}{ Median } & \multirow{2}{*}{$\begin{array}{c}\text { Exceed. } \\
\text { Prob. }\end{array}$} & \multicolumn{2}{|c|}{ Worst $5 \%$} & \multirow{2}{*}{$\begin{array}{c}\text { Exceed. } \\
\text { Prob. }\end{array}$} \\
\hline & & $\%$ TOC & $\% \mathrm{H} 2 \mathrm{O}$ & & $\% \mathrm{TOC}$ & $\% \mathrm{H} 2 \mathrm{O}$ & \\
\hline S107 & sludge & 0.1 & 42.4 & 0 & 0.6 & 21.3 & 1.4 \\
\hline S108 & $\mathrm{liq}$ & 0.5 & 59.7 & 0 & 1.9 & 44.0 & 0.1 \\
\hline S108 & salt & 0.4 & 21.6 & 0 & 3.3 & 15.5 & 9.6 \\
\hline S108 & sludge & 0.1 & 42.4 & 0 & 0.6 & 21.3 & 1.4 \\
\hline S109 & $\operatorname{liq}$ & 0.5 & 59.7 & 0 & 1.9 & 44.0 & 0.1 \\
\hline S109 & salt & 0.4 & 21.6 & 0 & 3.3 & 15.5 & 9.6 \\
\hline S109 & sludge & 0.1 & 42.4 & 0 & 0.6 & 21.3 & 1.4 \\
\hline S110 & $\operatorname{liq}$ & 0.7 & 59.7 & 0 & 2.8 & 44.0 & 0.2 \\
\hline S110 & salt & 0.4 & 21.6 & 0 & 3.3 & 15.5 & 9.6 \\
\hline S110 & sludge & 0.1 & 42.4 & 0 & 0.6 & 21.3 & 1.4 \\
\hline $\mathrm{S} 111$ & liq & 0.4 & 51.7 & 0 & 1.6 & 36.0 & 0.0 \\
\hline S111 & salt & 0.4 & 15.9 & 0 & 3.3 & 11.5 & 16.4 \\
\hline S111 & sludge & 0.1 & 42.4 & 0 & 0.6 & 21.3 & 1.4 \\
\hline $\mathrm{S} 112$ & $\mathrm{liq}$ & 0.5 & 59.7 & 0 & 1.9 & 44.0 & 0.1 \\
\hline S112 & salt & 0.4 & 21.6 & 0 & 3.3 & 15.5 & 9.6 \\
\hline $\mathrm{S} 112$ & sludge & 0.1 & 42.4 & 0 & 0.6 & 21.3 & 1.4 \\
\hline SX101 & liq & 0.2 & 84.3 & 0 & 1.0 & 68.6 & 0.0 \\
\hline SX101 & salt & 0.4 & 12.4 & 0 & 3.3 & 8.9 & 21.5 \\
\hline SX101 & sludge & 0.1 & 42.4 & 0 & 0.6 & 21.3 & 1.4 \\
\hline SX102 & liq & 0.5 & 59.7 & 0 & 1.9 & 44.0 & 0.1 \\
\hline SX102 & salt & 0.4 & 13.3 & 0 & 3.3 & 9.6 & 20.2 \\
\hline SX102 & sludge & 0.1 & 42.4 & 0 & 0.6 & 21.3 & 1.4 \\
\hline SX103 & liq & 0.5 & 59.7 & 0 & 1.9 & 44.0 & 0.1 \\
\hline SX103 & salt & 0.4 & 12.4 & 0 & 3.3 & 8.9 & 21.5 \\
\hline SX103 & sludge & 0.1 & 42.4 & 0 & 0.6 & 21.3 & 1.4 \\
\hline SX104 & liq & 0.3 & 57.4 & 0 & 1.2 & 41.7 & 0.0 \\
\hline SX104 & salt & 0.4 & 11.8 & 0 & 3.3 & 8.5 & 22.7 \\
\hline SX104 & sludge & 0.1 & 42.4 & 0 & 0.6 & 21.3 & 1.4 \\
\hline SX105 & liq & 0.5 & 59.7 & 0 & 1.9 & 44.0 & 0.1 \\
\hline SX105 & salt & 0.4 & 12.8 & 0 & 3.3 & 9.2 & 21.1 \\
\hline SX105 & sludge & 0.1 & 42.4 & 0 & 0.6 & 21.3 & 1.4 \\
\hline SX106 & liq & 2.0 & 50.3 & 0 & 20 & 34.6 & 0.6 \\
\hline SX106 & salt & 0.4 & 12.4 & 0 & 3.3 & 8.9 & 21.5 \\
\hline SX106 & sludge & 0.1 & 42.4 & 0 & 0.6 & 21.3 & 1.4 \\
\hline SX107 & liq & 0.3 & 67.9 & 0 & 1.3 & 52.2 & 0.0 \\
\hline SX107 & salt & NA & $\mathrm{NA}$ & NA & NA & NA & NA \\
\hline SX107 & sludge & 0.2 & 44.7 & 0 & 0.6 & 23.6 & 0.3 \\
\hline SX108 & liq & 0.3 & 66.2 & 0 & 1.2 & 50.5 & 0.0 \\
\hline SX108 & salt & $\mathrm{NA}$ & $\mathrm{NA}$ & NA & NA & NA & NA \\
\hline SX108 & sludge & 0.2 & 44.7 & 0 & 0.6 & 23.6 & 0.3 \\
\hline SX109 & liq. & 0.3 & 66.2 & 0 & 1.2 & 50.5 & 0.0 \\
\hline SX109 & salt & NA & $\mathrm{NA}$ & NA & NA & NA & NA \\
\hline SX109 & sludge & 0.2 & 44.7 & 0 & 0.6 & 23.6 & 0.3 \\
\hline SX110 & liq & NA & $\mathrm{NA}$ & $\mathrm{NA}$ & $\mathrm{NA}$ & $\mathrm{NA}$ & NA \\
\hline
\end{tabular}




\begin{tabular}{|c|c|c|c|c|c|c|c|}
\hline \multirow[b]{2}{*}{ Tank } & \multirow[b]{2}{*}{ phase } & \multicolumn{2}{|c|}{ Median } & \multirow{2}{*}{$\begin{array}{c}\text { Exceed. } \\
\text { Prob. }\end{array}$} & \multicolumn{2}{|c|}{ Worst $5 \%$} & \multirow{2}{*}{$\begin{array}{c}\text { Exceed. } \\
\text { Prob. }\end{array}$} \\
\hline & & $\% \mathrm{TOC}$ & $\% \mathrm{H} 2 \mathrm{O}$ & & $\% \mathrm{TOC}$ & $\% \mathrm{H} 2 \mathrm{O}$ & \\
\hline SX110 & salt & $\mathrm{NA}$ & NA & $\mathrm{NA}$ & NA & $\mathrm{NA}$ & $\mathrm{NA}$ \\
\hline SX110 & sludge & 0.1 & 44.7 & 0 & 0.6 & 23.6 & 1.4 \\
\hline SX111 & liq & 0.3 & 69.2 & 0 & 1.1 & 53.5 & 0.0 \\
\hline SX111 & salt & $\mathrm{NA}$ & $\mathrm{NA}$ & $\mathrm{NA}$ & $\mathrm{NA}$ & $\mathrm{NA}$ & $\mathrm{NA}$ \\
\hline SX111 & sludge & 0.1 & 44.7 & 0 & 0.6 & 23.6 & 1.4 \\
\hline SX112 & liq & 0.3 & 66.2 & 0 & 1.2 & 50.5 & 0.0 \\
\hline SX112 & salt & $\mathrm{NA}$ & $\mathrm{NA}$ & $\mathrm{NA}$ & $\mathrm{NA}$ & $\mathrm{NA}$ & NA \\
\hline SX112 & sludge & 0.2 & 44.7 & 0 & 0.6 & 23.6 & 0.3 \\
\hline SX113 & liq & NA & NA & NA & NA & $\mathrm{NA}$ & NA \\
\hline SX113 & salt & $\mathrm{NA}$ & NA & $\mathrm{NA}$ & NA & $\mathrm{NA}$ & NA \\
\hline SX113 & sludge & 0.1 & 44.7 & 0 & 0.6 & 23.6 & 1.4 \\
\hline SX114 & liq & 0.3 & 66.8 & 0 & 1.1 & 51.1 & 0.0 \\
\hline SX114 & salt & NA & NA & NA & $\mathrm{NA}$ & $\mathrm{NA}$ & NA \\
\hline SX114 & sludge & 0.1 & 44.7 & 0 & 0.6 & 23.6 & 1.4 \\
\hline SX115 & liq & $\mathrm{NA}$ & $\mathrm{NA}$ & NA & $\mathrm{NA}$ & $\mathrm{NA}$ & NA \\
\hline SX115 & salt & NA & $\mathrm{NA}$ & $\dot{\mathrm{NA}}$ & $\mathrm{NA}$ & NA & NA \\
\hline SX115 & sludge & 0.2 & 44.7 & 0 & 0.6 & 23.6 & 0.3 \\
\hline T101 & liq & 0.1 & 65.0 & 0 & 0.5 & 49.3 & 0.0 \\
\hline T101 & salt & $\mathrm{NA}$ & NA & NA & NA & NA & NA \\
\hline T101 & sludge & 0.1 & 44.7 & 0 & 0.6 & 23.6 & 1.4 \\
\hline $\mathrm{T} 102$ & liq & 0.2 & 65.0 & 0 & 0.8 & 49.3 & 0.0 \\
\hline $\mathrm{T} 102$ & salt & NA & $\mathrm{NA}$ & $\mathrm{NA}$ & $\mathrm{NA}$ & $\mathrm{NA}$ & $\mathrm{NA}$ \\
\hline $\mathrm{T} 102$ & sludge & 0.1 & 44.7 & 0 & 0.6 & 23.6 & 1.4 \\
\hline T103 & liq & 0.2 & 65.0 & 0. & 0.8 & 49.3 & 0.0 \\
\hline T103 & salt & $\mathrm{NA}$ & NA & NA & NA & $\mathrm{NA}$ & NA \\
\hline $\mathrm{T} 103$ & sludge & 0.1 & 44.7 & 0 & 0.6 & 23.6 & 1.4 \\
\hline T104 & liq & 0.1 & 65.0 & 0 & 0.5 & 49.3 & 0.0 \\
\hline T104 & salt & $\mathrm{NA}$ & $\mathrm{NA}$ & $\mathrm{NA}$ & $N A$ & $\mathrm{NA}$ & $\mathrm{NA}$ \\
\hline T104 & sludge & 0.1 & 55.0 & 0 & 0.2 & 33.9 & 0.0 \\
\hline $\mathrm{T} 105$ & liq & 0.3 & 65.0 & 0 & 1.1 & 49.3 & 0.1 \\
\hline $\mathrm{T} 105$ & salt & $\mathrm{NA}$ & $\mathrm{NA}$ & NA & NA & $\mathrm{NA}$ & $\mathrm{NA}$ \\
\hline T105 & sludge & 0.1 & 35.9 & 0 & 0.4 & 14.8 & 0.1 \\
\hline T106 & liq & 0.3 & 65.0 & 0 & 1.1 & 49.3 & 0.1 \\
\hline T106 & salt & $\mathrm{NA}$ & NA & NA & $\mathrm{NA}$ & $\mathrm{NA}$ & $\mathrm{NA}$ \\
\hline T106 & sludge & 0.1 & 35.9 & 0 & 0.4 & 14.8 & 0.1 \\
\hline T107 & liq & 0.1 & 80.9 & 0 & 0.3 & 65.2 & 0.0 \\
\hline T107 & salt & $\mathrm{NA}$ & NA & NA & NA & NA & NA \\
\hline T107 & sludge & 0.1 & 48.2 & 0 & 0.3 & 27.1 & 0.0 \\
\hline $\mathrm{T} 108$ & liq & $\mathrm{NA}$ & $\mathrm{NA}$ & $\mathrm{NA}$ & $\mathrm{NA}$ & $\mathrm{NA}$ & NA \\
\hline T108 & salt & NA & NA & NA & $\mathrm{NA}$ & NA & $\mathrm{NA}$ \\
\hline T108 & sludge & 0.1 & 49.5 & 0 & 0.3 & 28.3 & 0.0 \\
\hline T109 & liq & NA & $\mathrm{NA}$ & NA & NA & NA & $\mathrm{NA}$ \\
\hline $\mathrm{T} 109$ & salt & NA & NA & NA & NA & NA & NA \\
\hline $\mathrm{T} 109$ & sludge & 0.1 & 44.7 & 0 & 0.6 & 23.6 & 1.4 \\
\hline
\end{tabular}




\begin{tabular}{|c|c|c|c|c|c|c|c|}
\hline \multirow[b]{2}{*}{ Tank } & \multirow[b]{2}{*}{ phase } & \multicolumn{2}{|c|}{ Median } & \multirow{2}{*}{$\begin{array}{c}\text { Exceed. } \\
\text { Prob. }\end{array}$} & \multicolumn{2}{|c|}{ Worst $5 \%$} & \multirow{2}{*}{$\begin{array}{c}\text { Exceed. } \\
\text { Prob. }\end{array}$} \\
\hline & & $\% \mathrm{TOC}$ & $\% \mathrm{H} 2 \mathrm{O}$ & & $\% \mathrm{TOC}$ & $\% \mathrm{H} 2 \mathrm{O}$ & \\
\hline T110 & liq & 0.3 & 82.9 & 0 & 1.0 & 67.2 & 0.0 \\
\hline $\mathrm{T} 110$ & salt & $\mathrm{NA}$ & $\mathrm{NA}$ & $\mathrm{NA}$ & NA & $\mathrm{NA}$ & NA \\
\hline $\mathrm{T} 110$ & sludge & 0.2 & 44.7 & 0 & 0.9 & 23.6 & 1.1 \\
\hline $\mathrm{T} 111$ & liq & 0.3 & 75.3 & 0 & 1.0 & 59.6 & 0.0 \\
\hline $\mathrm{T} 111$ & salt & $\mathrm{NA}$ & $\mathrm{NA}$ & $\mathrm{NA}$ & NA & NA & NA \\
\hline $\mathrm{T} 111$ & sludge & 0.3 & 44.7 & 0 & 1.1 & 23.6 & 0.0 \\
\hline $\mathrm{T} 112$ & $\mathrm{liq}$ & 0.2 & 81.7 & 0 & 0.9 & 66.0 & 0.0 \\
\hline $\mathrm{T} 112$ & salt & NA & $\mathrm{NA}$ & $\mathrm{NA}$ & $\mathrm{NA}$ & $\mathrm{NA}$ & NA \\
\hline $\mathrm{T} 112$ & sludge & 0.2 & 44.7 & 0 & 0.9 & 23.6 & 1.1 \\
\hline $\mathrm{T} 201$ & liq & 0.3 & 65.0 & 0 & 1.1 & 49.3 & 0.1 \\
\hline $\mathrm{T} 201$ & salt & $\mathrm{NA}$ & $\mathrm{NA}$ & $\mathrm{NA}$ & NA & $\mathrm{NA}$ & NA \\
\hline $\mathrm{T} 201$ & sludge & 0.2 & 64.9 & 0 & 0.9 & 43.8 & 0.0 \\
\hline T202 & liq & 0.3 & 65.0 & 0 & 1.1 & 49.3 & 0.1 \\
\hline $\mathrm{T} 202$ & salt & $\mathrm{NA}$ & NA & NA & $\mathrm{NA}$ & $\mathrm{NA}$ & NA \\
\hline $\mathrm{T} 202$ & sludge & 0.2 & 64.9 & 0 & 0.9 & 43.8 & 0.0 \\
\hline $\mathrm{T} 203$ & liq & 0.3 & 65.0 & 0 & 1.1 & 49.3 & 0.1 \\
\hline $\mathrm{T} 203$ & salt & $\mathrm{NA}$ & $\mathrm{NA}$ & $\mathrm{NA}$ & $\mathrm{NA}$ & $\mathrm{NA}$ & NA \\
\hline $\mathrm{T} 203$ & sludge & 0.2 & 64.9 & 0 & 0.9 & 43.8 & 0.0 \\
\hline $\mathrm{T} 204$ & liq & 0.3 & 65.0 & 0 & 1.1 & 49.3 & 0.1 \\
\hline $\mathrm{T} 204$ & salt & $\mathrm{NA}$ & $\mathrm{NA}$ & $\mathrm{NA}$ & NA & $\mathrm{NA}$ & NA \\
\hline $\mathrm{T} 204$ & sludge & 0.3 & 64.9 & 0 & 1.3 & 43.8 & 0.0 \\
\hline TX101 & liq & 0.3 & 65.0 & 0 & 1.1 & 49.3 & 0.1 \\
\hline TX101 & salt & $\mathrm{NA}$ & $\mathrm{NA}$ & $\mathrm{NA}$ & $\mathrm{NA}$ & $\mathrm{NA}$ & $\mathrm{NA}$ \\
\hline TX101 & sludge & 0.1 & 44.7 & 0 & 0.6 & 23.6 & 1.4 \\
\hline TX102 & liq & 0.3 & 59.7 & 0 & 1.3 & 44.0 & 0.0 \\
\hline TX102 & salt & 0.4 & 8.5 & 0 & 3.3 & 6.1 & 28.1 \\
\hline TX102 & sludge & NA & NA & NA & NA & $\mathrm{NA}$ & $\mathrm{NA}$ \\
\hline TX103 & liq & 0.3 & 57.5 & 0 & 1.1 & 41.8 & 0.0 \\
\hline TX103 & salt & NA & $\mathrm{NA}$ & $\mathrm{NA}$ & $\mathrm{NA}$ & $\mathrm{NA}$ & NA \\
\hline TX103 & sludge & 0.1 & 44.7 & 0 & 0.6 & 23.6 & 1.4 \\
\hline TX104 & liq & 0.5 & 54.9 & 0 & 1.9 & 39.2 & 0.0 \\
\hline TX104 & salt & 0.4 & 21.6 & 0 & 3.3 & 15.5 & 9.6 \\
\hline TX104 & sludge & $\mathrm{NA}$ & $\mathrm{NA}$ & $\mathrm{NA}$ & $\mathrm{NA}$ & $\mathrm{NA}$ & $\mathrm{NA}$ \\
\hline TX105 & liq & 0.6 & 59.7 & 0 & 2.4 & 44.0 & 0.1 \\
\hline TX105 & salt & 0.4 & 8.5 & 0 & 3.3 & 6.1 & 28.1 \\
\hline TX105 & sludge & $\mathrm{NA}$ & $\mathrm{NA}$ & NA & NA & $\mathrm{NA}$ & $\mathrm{NA}$ \\
\hline TX106 & liq & 0.4 & 59.7 & 0 & 1.8 & 44.0 & 0.0 \\
\hline TX106 & salt & 0.4 & 8.5 & 0 & 3.3 & 6.1 & 28.1 \\
\hline TX106 & sludge & NA & $\mathrm{NA}$ & $\mathrm{NA}$ & $\mathrm{NA}$ & NA & NA \\
\hline TX107 & liq & 0.5 & 59.7 & 0 & 1.9 & 44.0 & 0.1 \\
\hline TX107 & salt & 0.4 & 21.6 & 0 & 3.3 & 15.5 & 9.6 \\
\hline TX107 & sludge & $\mathrm{NA}$ & $\mathrm{NA}$ & $\mathrm{NA}$ & NA & $\mathrm{NA}$ & NA \\
\hline TX108 & $\mathrm{liq}$ & NA & $\mathrm{NA}$ & NA & $\mathrm{NA}$ & $\mathrm{NA}$ & NA \\
\hline TX108 & salt & 0.6 & 16.9 & 0 & 4.7 & 12.2 & 30.1 \\
\hline
\end{tabular}




\begin{tabular}{|c|c|c|c|c|c|c|c|}
\hline \multirow[b]{2}{*}{ Tank } & \multirow[b]{2}{*}{ phase } & \multicolumn{2}{|c|}{ Median } & \multirow{2}{*}{$\begin{array}{c}\text { Exceed. } \\
\text { Prob. }\end{array}$} & \multicolumn{2}{|c|}{ Worst $5 \%$} & \multirow{2}{*}{$\begin{array}{c}\text { Exceed. } \\
\text { Prob. }\end{array}$} \\
\hline & & $\% \mathrm{TOC}$ & $\% \mathrm{H} 2 \mathrm{O}$ & & $\%$ TOC & $\% \mathrm{H} 2 \mathrm{O}$ & \\
\hline TX108 & sludge & $\mathrm{NA}$ & NA & $\mathrm{NA}$ & $\mathrm{NA}$ & NA & $\mathrm{NA}$ \\
\hline TX109 & liq & 0.4 & 59.6 & 0 & 1.6 & 44.0 & 0.1 \\
\hline TX109 & salt & 0.5 & 16.9 & 0 & 4.0 & 12.2 & 23.5 \\
\hline TX109 & sludge & NA & NA & NA & NA & $\mathrm{NA}$ & NA \\
\hline TX110 & $\operatorname{liq}$ & 0.3 & 52.3 & 0 & 1.4 & 36.6 & 0.0 \\
\hline TX110 & salt & 0.5 & 16.9 & 0 & 4.0 & 12.2 & 23.5 \\
\hline TX110 & sludge & NA & NA & NA & $\mathrm{NA}$ & $\mathrm{NA}$ & NA \\
\hline TX111 & liq & 0.3 & 59.6 & 0 & 1.4 & 44.0 & 0.0 \\
\hline TX111 & salt & 0.5 & 16.9 & 0 & 4.0 & 12.2 & 23.5 \\
\hline TX111 & sludge & NA & $\mathrm{NA}$ & NA & $\mathrm{NA}$ & NA & NA \\
\hline TX112 & $\mathrm{liq}$ & 0.3 & 59.6 & 0 & 1.1 & 44.0 & 0.0 \\
\hline TX112 & salt & 0.5 & 16.9 & 0 & 4.0 & 12.2 & 23.5 \\
\hline TX112 & sludge & $\mathrm{NA}$ & NA & NA & NA & NA & NA \\
\hline TX113 & liq & 0.3 & 59.6 & 0 & 1.1 & 44.0 & 0.1 \\
\hline TX113 & salt & 0.5 & 16.9 & 0 & 4.0 & 12.2 & 23.5 \\
\hline TX113 & sludge & $\mathrm{NA}$ & $\mathrm{NA}$ & NA & $\mathrm{NA}$ & $\mathrm{NA}$ & NA \\
\hline TX114 & liq & 0.2 & 59.6 & 0 & 1.0 & 44.0 & 0.0 \\
\hline TX114 & salt & 0.5 & 16.9 & 0 & 4.0 & 12.2 & 23.5 \\
\hline TX114 & sludge & NA & $\mathrm{NA}$ & NA & NA & NA & $\mathrm{NA}$ \\
\hline TX115 & liq & 0.1 & 63.9 & 0 & 0.5 & 48.2 & 0.0 \\
\hline TX115 & salt & 0.6 & 16.9 & 0 & 5.0 & 12.2 & 33.2 \\
\hline TX115 & sludge & NA & $\mathrm{NA}$ & $\mathrm{NA}$ & $\mathrm{NA}$ & $\mathrm{NA}$ & $\mathrm{NA}$ \\
\hline TX116 & liq & 0.2 & 59.6 & 0 & 0.7 & 44.0 & 0.0 \\
\hline TX116 & salt & 0.5 & 16.9 & 0 & 4.0 & 12.2 & 23.5 \\
\hline TX116 & sludge & $\mathrm{NA}$ & $\mathrm{NA}$ & NA & NA & $\mathrm{NA}$ & NA \\
\hline TX117 & liq : & 0.3 & 59.6 & 0 & 1.1 & 44.0 & 0.1 \\
\hline TX117 & salt & 0.5 & 16.9 & 0 & 4.0 & 12.2 & 23.5 \\
\hline TX117 & sludge & $\mathrm{NA}$ & NA & NA & NA & $\mathrm{NA}$ & $\mathrm{NA}$ \\
\hline TX118 & liq & 0.2 & 60.1 & 0 & 4.2 & 44.4 & 1.0 \\
\hline TX118 & salt & 0.6 & 16.9 & 0 & 4.7 & 12.2 & 30.1 \\
\hline TX118 & sludge & NA & NA & NA & NA & NA & NA \\
\hline TY101 & liq & $\mathrm{NA}$ & NA & NA & $\mathrm{NA}$ & NA & $\mathrm{NA}$ \\
\hline TY101 & salt & NA & NA & NA & $\mathrm{NA}$ & NA & $\mathrm{NA}$ \\
\hline TY101 & sludge & 0.0 & 44.0 & 0 & 0.0 & 22.9 & 0.0 \\
\hline TY102 & liq & 0.3 & 59.6 & 0 & 1.1 & 44.0 & 0.1 \\
\hline TY102 & salt & 0.5 & 51.9 & 0 & 4.0 & 37.3 & 0.0 \\
\hline TY102 & sludge & NA & NA & NA & $\mathrm{NA}$ & $\mathrm{NA}$ & $\mathrm{NA}$ \\
\hline TY103 & liq & 0.2 & 65.0 & 0 & 0.8 & 49.3 & 0.0 \\
\hline TY103 & salt & NA & NA & $\mathrm{NA}$ & NA & NA & NA \\
\hline TY103 & sludge & 0.1 & 51.0 & 0 & 0.3 & 29.9 & 0.0 \\
\hline TY104 & liq & 0.2 & 65.0 & 0 & 0.8 & 49.3 & 0.0 \\
\hline TY104 & salt & NA & $\mathrm{NA}$ & NA & NA & $\mathrm{NA}$ & $\mathrm{NA}$ \\
\hline TY104 & sludge & 0.2 & 51.0 & 0 & 0.9 & 29.9 & 0.0 \\
\hline TY105 & liq & $\mathrm{NA}$ & $\mathrm{NA}$ & NA & NA & $\mathrm{NA}$ & $\mathrm{NA}$ \\
\hline
\end{tabular}




\begin{tabular}{|c|c|c|c|c|c|c|c|}
\hline \multirow[b]{2}{*}{ Tank } & \multirow[b]{2}{*}{ phase } & \multicolumn{2}{|c|}{ Median } & \multirow{2}{*}{$\begin{array}{c}\text { Exceed. } \\
\text { Prob. }\end{array}$} & \multicolumn{2}{|c|}{ Worst $5 \%$} & \multirow{2}{*}{$\begin{array}{c}\text { Exceed. } \\
\text { Prob. }\end{array}$} \\
\hline & & $\%$ TOC & $\% \mathrm{H} 2 \mathrm{O}$ & & $\% \mathrm{TOC}$ & $\% \mathrm{H} 2 \mathrm{O}$ & \\
\hline TY105 & salt & $\mathrm{NA}$ & $\mathrm{NA}$ & $\mathrm{NA}$ & $\mathrm{NA}$ & $\mathrm{NA}$ & $\mathrm{NA}$ \\
\hline TY105 & sludge & 0.1 & 40.0 & 0 & 0.4 & 18.9 & 0.0 \\
\hline TY106 & liq & $\mathrm{NA}$ & $\mathrm{NA}$ & NA & NA & NA & NA \\
\hline TY106 & salt & NA & $\mathrm{NA}$ & NA & $\mathrm{NA}$ & NA & $\mathrm{NA}$ \\
\hline TY106 & sludge & 0.1 & 40.0 & 0 & 0.6 & 18.9 & 0.0 \\
\hline U101 & liq & 0.3 & 66.2 & 0 & 1.2 & 50.5 & 0.0 \\
\hline U101 & salt & $\mathrm{NA}$ & NA & NA & NA & NA & NA \\
\hline U101 & sludge & 0.2 & 44.7 & 0 & 0.6 & 23.6 & 0.3 \\
\hline U102 & liq & 0.4 & 63.7 & 0 & 1.8 & 48.0 & 0.0 \\
\hline U102 & salt & 0.6 & 43.1 & 0 & 5.0 & 31.0 & 1.2 \\
\hline U102 & sludge & 0.3 & 29.8 & 0 & 1.2 & 8.7 & 10.2 \\
\hline U103 & liq & 0.4 & 63.5 & 0 & 1.8 & 47.8 & 0.0 \\
\hline U103 & salt & 0.6 & 43.1 & 0 & 5.0 & 31.0 & 1.2 \\
\hline U103 & sludge & 0.4 & 29.8 & 0 & 1.6 & 8.7 & 9.6 \\
\hline U104 & liq & 0.3 & 65.0 & 0 & 1.1 & 49.3 & 0.1 \\
\hline U104 & salt & NA & $\mathrm{NA}$ & NA & NA & $\mathrm{NA}$ & NA \\
\hline U104 & sludge & 0.1 & 44.7 & 0 & 0.6 & 23.6 & 1.4 \\
\hline U105 & $\operatorname{liq}$ & 0.3 & 64.5 & 0 & 1.1 & 48.9 & 0.0 \\
\hline U105 & salt & 0.7 & 21.1 & 0 & 5.2 & 15.2 & 27.8 \\
\hline U105 & sludge & 0.1 & 45.6 & 0 & 0.6 & 24.5 & 0.7 \\
\hline U106 & $\operatorname{liq}$ & 1.6 & 62.8 & 0 & 6.2 & 47.2 & 0.0 \\
\hline U106 & salt & 0.6 & 43.1 & 0 & 5.0 & 31.0 & 1.2 \\
\hline U106 & sludge & 0.3 & 29.8 & 0 & 1.2 & 8.7 & 10.2 \\
\hline U107 & liq & 0.3 & 64.5 & 0 & 1.1 & 48.9 & 0.0 \\
\hline U107 & salt & 0.7 & 21.6 & 0 & 5.2 & 15.5 & 25.3 \\
\hline U107 & sludge & 0.1 & 45.6 & 0 & 0.6 & 24.5 & 0.7 \\
\hline U108 & liq & 0.3 & 64.5 & 0 & 1.1 & 48.9 & 0.0 \\
\hline U108 & salt & 0.7 & 21.6 & 0 & 5.2 & 15.5 & 25.3 \\
\hline U108 & sludge & 0.1 & 45.6 & 0 & 0.6 & 24.5 & 0.7 \\
\hline U109 & liq & 0.3 & 63.9 & 0 & 1.1 & 48.2 & 0.0 \\
\hline U109 & salt & 0.7 & 30.4 & 0 & 5.2 & 21.8 & 7.5 \\
\hline U109 & sludge & 0.1 & 45.6 & 0 & 0.6 & 24.5 & 0.7 \\
\hline U110 & liq & 0.3 & 65.0 & 0 & 1.1 & 49.3 & 0.1 \\
\hline U110 & salt & NA & NA & NA & NA & $\mathrm{NA}$ & $\mathrm{NA}$ \\
\hline U110 & sludge & 0.1 & 35.9 & 0 & 0.3 & 14.8 & 0.0 \\
\hline U111 & liq & 1.0 & 63.9 & 0 & 4.2 & 48.2 & 0.3 \\
\hline U111 & salt & 0.6 & 37.7 & 0 & 5.0 & 27.2 & 0.6 \\
\hline U111 & sludge & 0.3 & 29.8 & 0 & 1.2 & 8.7 & 10.2 \\
\hline U112 & liq & 0.3 & 65.0 & 0 & 1.1 & 49.3 & 0.1 \\
\hline U112 & salt & $\mathrm{NA}$ & NA & $\mathrm{NA}$ & NA & $\mathrm{NA}$ & NA \\
\hline $\mathrm{U} 112$ & sludge & 0.1 & 44.7 & 0 & 0.6 & 23.6 & 1.4 \\
\hline U201 & liq & 0.3 & 69.2 & 0 & 1.1 & 53.5 & 0.0 \\
\hline U201 & salt & $\mathrm{NA}$ & $\mathrm{NA}$ & NA & $\mathrm{NA}$ & $\mathrm{NA}$ & NA \\
\hline U201 & sludge & 0.1 & 44.7 & 0 & 0.6 & 23.6 & 1.4 \\
\hline
\end{tabular}




\begin{tabular}{|c|c|c|c|c|c|c|c|}
\hline \multirow[b]{2}{*}{ Tank } & \multirow[b]{2}{*}{ phase } & \multicolumn{2}{|c|}{ Median } & \multirow{2}{*}{$\begin{array}{l}\text { Exceed. } \\
\text { Prob. }\end{array}$} & \multicolumn{2}{|c|}{ Worst $5 \%$} & \multirow{2}{*}{$\begin{array}{c}\text { Exceed. } \\
\text { Prob. }\end{array}$} \\
\hline & & $\% \mathrm{TOC}$ & $\% \mathrm{H} 2 \mathrm{O}$ & & $\% \mathrm{TOC}$ & $\% \mathrm{H} 2 \mathrm{O}$ & \\
\hline U202 & liq & 0.3 & 74.9 & 0 & 1.1 & 59.2 & 0.0 \\
\hline $\mathrm{U} 202$ & salt & NA & $\mathrm{NA}$ & NA & $\mathrm{NA}$ & NA & NA \\
\hline U202 & sludge & 0.1 & 44.7 & 0 & 0.6 & 23.6 & 1.4 \\
\hline U203 & liq & 0.3 & 69.2 & 0 & 1.1 & 53.5 & 0.0 \\
\hline U203 & salt & NA & NA & NA & NA & NA & NA \\
\hline U203 & sludge & 0.1 & 44.7 & 0 & 0.6 & 23.6 & 1.4 \\
\hline U204 & liq & 0.3 & 65.0 & 0 & 1.1 & 49.3 & 0.1 \\
\hline U204 & salt & $\mathrm{NA}$ & $\mathrm{NA}$ & $\mathrm{NA}$ & NA & $\mathrm{NA}$ & $\mathrm{NA}$ \\
\hline U204 & sludge & 0.1 & 37.0 & 0 & 0.6 & 15.9 & 2.7 \\
\hline
\end{tabular}


Appendix J

TOC Estimates for 149 Single-Shell Tanks 


\begin{tabular}{|c|c|c|c|c|c|c|c|c|c|}
\hline \multirow[b]{2}{*}{ Tank } & \multirow[b]{2}{*}{$\begin{array}{l}\stackrel{\Xi}{\Xi} \\
\text { 总 }\end{array}$} & \multirow[b]{2}{*}{$\begin{array}{l}\text { Number } \\
\text { of } \\
\text { Samples } \\
\text { for Tank } \\
\text { Waste }\end{array}$} & \multirow[b]{2}{*}{\begin{tabular}{|l|} 
Number \\
of \\
Samples \\
in \\
SORWT \\
Group
\end{tabular}} & \multicolumn{3}{|c|}{ Tank Median Estimate } & \multicolumn{3}{|c|}{ Worst $5 \%$ of the Waste } \\
\hline & & & & $\begin{array}{l}\text { Tank } \\
\text { Median } \\
\text { Estimate } \\
\text { of TOC } \\
\text { wt\% } \\
\text { (wet) }\end{array}$ & $\begin{array}{l}\text { Relative } \\
\text { Standard } \\
\text { Deviation } \\
\text { on Median }\end{array}$ & $\begin{array}{l}95 \% \\
\text { Confidence } \\
\text { Bound on } \\
\text { Tank TOC } \\
\text { Estimate } \\
\text { wt\% TOC } \\
\text { (wet) }\end{array}$ & $\begin{array}{l}\text { Estimate } \\
\text { of Worst } \\
5 \% \text { of } \\
\text { Waste, } \\
\text { wt\% (wet) }\end{array}$ & $\begin{array}{l}\text { Relative } \\
\text { Standard } \\
\text { Deviation } \\
\text { on Worst } \\
5 \% \text { of the } \\
\text { Waste }\end{array}$ & $\begin{array}{l}95 \% \\
\text { Confidence } \\
\text { Bound on } \\
\text { Worst } 5 \% \text { of } \\
\text { the Waste }\end{array}$ \\
\hline $\mathrm{A} 101$ & liq & 12 & 34 & $\begin{array}{r}0.9 \\
\end{array}$ & \begin{tabular}{|r|}
23 \\
\end{tabular} & $\begin{array}{r}1.5 \\
\end{array}$ & 3.8 & 25.5 & 6.3 \\
\hline $\mathrm{A} 102$ & liq & 11 & 34 & 0.4 & 24 & 0.6 & 1.6 & 26.3 & 2.7 \\
\hline $\mathrm{A} 103$ & liq & 6 & 34 & 0.6 & 31.2 & 1.2 & 2.5 & 33 & 4.8 \\
\hline $\mathrm{A} 105$ & liq & 0 & 0 & 0.3 & 87.2 & 1.6 & 1.1 & 87.8 & 6.4 \\
\hline A106 & liq & 2 & 2 & 0.1 & 385.3 & 140.4 & 25.00 & 599.2 & 25.00 \\
\hline AX101 & liq & 5 & 34 & 0.8 & 33.6 & 1.5 & 3 & 35.3 & 6.1 \\
\hline $\mathrm{AX} 102$ & liq & 3 & 7 & 1.1 & 41.7 & 2.5 & 4.4 & 43.1 & 10.4 \\
\hline $\mathrm{AX103}$ & liq & 4 & 7 & 0.8 & 37.3 & 1.7 & 3.3 & 38.9 & 7.1 \\
\hline B101 & liq & 0 & 0 & 0.3 & 87.2 & 1.6 & 1.1 & 87.8 & 6.4 \\
\hline B102 & liq & 0 & 0 & 0.3 & 87.2 & 1.6 & 1.1 & 87.8 & 6.4 \\
\hline B104 & liq & 0 & 0 & 0.3 & 87.2 & 1.6 & 1.1 & 87.8 & 6.4 \\
\hline B105 & liq & 0 & 8 & 0.3 & 76.8 & 1.3 & 1.1 & 77.5 & 5.4 \\
\hline B106 & liq & 0 & 2 & 0.2 & 82.5 & 1.1 & 0.8 & 83.2 & 4.3 \\
\hline $\mathrm{B} 107$ & liq & 0 & 1 & 0.3 & 85.1 & 1.6 & 1.1 & 85.8 & 6.3 \\
\hline B108 & liq & 0 & 1 & 0.3 & 85.1 & 1.6 & 1.1 & 85.8 & 6.3 \\
\hline B109 & liq & 0 & 1 & 0.3 & 85.1 & 1.6 & 1.1 & 85.8 & 6.3 \\
\hline B110 & liq & 0 & 0 & 0.3 & 87.2 & 1.6 & 1.1 & 87.8 & 6.4 \\
\hline B111 & liq & 0 & 0 & 0.3 & 87.2 & 1.6 & 1.1 & 87.8 & 6.4 \\
\hline B112 & liq & 0 & 0 & 0.3 & 87.2 & 1.6 & 1.1 & 87.8 & 6.4 \\
\hline B201 & liq & 0 & 0 & 0.3 & 87.2 & 1.6 & 1.1 & 87.8 & 6.4 \\
\hline B202 & liq & 0 & 0 & 0.3 & 87.2 & 1.6 & 1.1 & 87.8 & 6.4 \\
\hline B203 & liq & 0 & 0 & 0.3 & 87.2 & 1.6 & 1.1 & 87.8 & 6.4 \\
\hline B204 & liq & 0 & 0 & \begin{tabular}{l|l}
0.3 \\
\end{tabular} & 87.2 & 1.6 & 1.1 & 87.8 & 6.4 \\
\hline BX101 & liq & 0 & 7 & 0.4 & 78.1 & 1.7 & 1.5 & 78.8 & 7 \\
\hline BX102 & liq & 0 & 7 & 0.4 & 78.1 & 1.7 & 1.5 & $\begin{array}{ll}78.8 \\
\end{array}$ & 7 \\
\hline BX103 & liq & 0 & 7 & 0.4 & 78.1 & 1.7 & 1.5 & 78.8 & 7 \\
\hline BX104 & liq & 3 & 7 & 0.5 & 41.3 & 1.1 & 1.9 & 42.7 & 4.5 \\
\hline BX105 & liq & 2 & 7 & 0.5 & 47.5 & 1.4 & 2.2 & 48.7 & 5.8 \\
\hline BX106 & liq & 1 & 7 & 0.4 & 57.5 & 1.1 & 1.4 & 58.5 & 4.5 \\
\hline BX107 & liq & 1 & 2 & 0.2 & 59.6 & 0.7 & 0.8 & 60.6 & 2.8 \\
\hline BX108 & liq & 0 & 7 & 0.4 & 78.1 & 1.7 & 1.5 & 78.8 & 7 \\
\hline BX109 & liq & 1 & 7 & $\begin{array}{l}0.3 \\
\end{array}$ & 57.5 & 0.9 & 1.2 & 58.5 & 3.9 \\
\hline BX110 & liq & 1 & 2 & 0.3 & 59.6 & 1.2 & 1.4 & 60.6 & 4.7 \\
\hline BX112 & liq & 1 & 1 & 0.3 & 60.9 & 1 & 1.2 & 61.9 & 4.1 \\
\hline BY101 & liq & 0 & 6 & 0.2 & 78.3 & 1.2 & 1 & 79 & 4.8 \\
\hline BY102 & liq & 2 & 5 & 0.2 & 48.2 & 0.5 & 0.7 & 49.4 & 2 \\
\hline BY103 & liq & 1 & 6 & 0.2 & 57.6 & 0.7 & 0.9 & 58.6 & 2.9 \\
\hline BY104 & liq & 0 & 6 & 0.2 & 78.3 & 1.2 & 1 & 79 & 4.8 \\
\hline BY105 & liq & 2 & 6 & 0.2 & 47.5 & 0.6 & 0.9 & 48.8 & 2.4 \\
\hline BY106 & liq & 2 & 6 & 0.2 & 47.5 & 0.6 & 0.9 & 48.8 & 2.4 \\
\hline BY107 & liq & 1 & 6 & 0.3 & 57.6 & 0.9 & 1.1 & 58.6 & 3.5 \\
\hline BY108 & liq & 0 & 6 & 0.2 & 78.3 & 1.2 & 1 & 79 & 4.8 \\
\hline BY109 & liq & 3 & 5 & 0.3 & 41.8 & 0.7 & 1.2 & 43.2 & 3 \\
\hline
\end{tabular}




\begin{tabular}{|c|c|c|c|c|c|c|c|c|c|}
\hline \multirow[b]{2}{*}{ Tank } & \multirow[b]{2}{*}{ 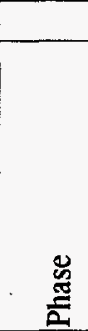 } & \multirow[b]{2}{*}{\begin{tabular}{|l} 
Number \\
of \\
Samples \\
for Tank \\
Waste \\
\end{tabular}} & \multirow[b]{2}{*}{$\begin{array}{l}\text { Number } \\
\text { of } \\
\text { Samples } \\
\text { in } \\
\text { SORWT } \\
\text { Group } \\
\end{array}$} & \multicolumn{3}{|c|}{ Tank Median Estimate } & \multicolumn{3}{|c|}{ Worst $5 \%$ of the Waste } \\
\hline & & & & \begin{tabular}{|l|} 
Tank \\
Median \\
Estimate \\
of TOC \\
wt\% \\
(wet)
\end{tabular} & $\begin{array}{l}\text { Relative } \\
\text { Standard } \\
\text { Deviation } \\
\text { on Median }\end{array}$ & $\begin{array}{l}95 \% \\
\text { Confidence } \\
\text { Bound on } \\
\text { Tank TOC } \\
\text { Estimate } \\
\text { wt\% TOC } \\
\text { (wet) }\end{array}$ & $\begin{array}{l}\text { Estimate } \\
\text { of Worst } \\
5 \% \text { of } \\
\text { Waste, } \\
\text { wt\% (wet) }\end{array}$ & $\begin{array}{l}\text { Relative } \\
\text { Standard } \\
\text { Deviation } \\
\text { on Worst } \\
5 \% \text { of the } \\
\text { Waste }\end{array}$ & $\begin{array}{l}95 \% \\
\text { Confidence } \\
\text { Bound on } \\
\text { Worst } 5 \% \text { of } \\
\text { the Waste }\end{array}$ \\
\hline BY110 & liq & 0 & 6 & 0.2 & 78.3 & 1.2 & 1 & 79 & 4.8 \\
\hline BY112 & liq & 0 & 6 & 0.2 & 78.3 & 1.2 & 1 & 79 & 4.8 \\
\hline $\mathrm{C} 101$ & liq & 0 & 7 & 0.4 & 78.1 & 1.7 & 1.5 & 78.8 & 7 \\
\hline $\mathrm{C} 102$ & liq & 1 & 1 & 0.3 & 60.9 & 0.9 & 1.1 & 61.9 & 3.8 \\
\hline $\mathrm{C} 103$ & Iiq & 6 & 7 & 0.6 & 31.7 & 1.1 & 2.3 & 33.5 & 4.4 \\
\hline $\mathrm{C} 104$ & liq & 1 & 1 & 0.5 & 60.9 & 1.7 & 2 & 61.9 & 7 \\
\hline $\mathrm{C} 105$ & liq & 1 & 1 & 0.3 & 60.9 & 0.9 & 1 & 61.9 & 3.5 \\
\hline C106 & liq & 1 & 7 & 0.3 & 58.7 & 0.9 & 1.1 & 59.7 & 3.5 \\
\hline C107 & liq & 1 & 1 & 0.2 & 60.9 & 0.5 & 0.6 & 61.9 & 2.1 \\
\hline $\mathrm{Cl09}$ & liq & 0 & 6 & 0.2 & 80.3 & 0.9 & 0.7 & 81 & 3.5 \\
\hline $\mathrm{C} 110$ & liq & 1 & 2 & 0.1 & 59.6 & 0.4 & 0.5 & 60.6 & 1.6 \\
\hline $\mathrm{C} 112$ & liq & 2 & 6 & 0.2 & 48.1 & 0.4 & 0.7 & 49.3 & 1.7 \\
\hline S101 & liq & 0 & 29 & 0.5 & 73.4 & 2 & 1.9 & 74.2 & 8.2 \\
\hline S102 & liq & 2 & 29 & 0.9 & 46.1 & 2.2 & 3.5 & 47.4 & 9.2 \\
\hline $\mathrm{S} 103$ & liq & 0 & 29 & 0.5 & 73.4 & 2 & 1.9 & 74.2 & 8.2 \\
\hline S104 & Iiq & 0 & 1 & 0.3 & 85.1 & 1.6 & 1.2 & 85.8 & 6.6 \\
\hline S105 & liq & $\overline{0}$ & 29 & 0.5 & 73.4 & 2 & 1.9 & 74.2 & 8.2 \\
\hline$\$ 106$ & liq & 0 & 29 & 0.5 & 73.4 & 2 & 1.9 & 74.2 & 8.2 \\
\hline$\$ 107$ & liq & 5 & 29 & 0.5 & 33.3 & 1 & 2 & 35.1 & 4.1 \\
\hline $\mathbf{S 1 0 8}$ & liq & 0 & 29 & 0.5 & 73.4 & 2 & 1.9 & 74.2 & 8.2 \\
\hline $\mathbf{S 1 0 9}$ & liq & 0 & 29 & 0.5 & 73.4 & 2 & 1.9 & 74.2 & 8.2 \\
\hline$S 110$ & liq & 1 & 29 & 0.7 & 55.2 & 2.1 & 2.8 & 56.3 & 8.5 \\
\hline S111 & liq & 3 & 29 & 0.4 & 40.4 & 0.9 & 1.6 & 41.8 & 3.6 \\
\hline $\mathbf{S 1 1 2}$ & liq & $\overline{0}$ & 29 & 0.5 & 73.4 & 2 & 1.9 & 74.2 & 8.2 \\
\hline SX101 & liq & 4 & 29 & 0.2 & 36.4 & 0.5 & 1 & 37.9 & 2.1 \\
\hline $\mathrm{SX} 102$ & liq & 0 & 29 & 0.5 & 73.4 & 2 & 1.9 & 74.2 & 8.2 \\
\hline SX103 & liq & 0 & 29 & 0.5 & 73.4 & 2 & 1.9 & 74.2 & 8.2 \\
\hline SX104 & liq & 6 & 29 & 0.3 & 31 & 0.6 & 1.2 & 32.8 & 2.3 \\
\hline SX105 & liq & 0 & 29 & 0.5 & 73.4 & 2 & 1.9 & 74.2 & 8.2 \\
\hline$\overline{S X 106}$ & liq & 4 & 29 & 2 & 477.2 & 25 & 20 & 594 & 25 \\
\hline SX107 & liq & 1 & 1 & \begin{tabular}{l|l}
0.3 \\
\end{tabular} & 60.9 & 1.1 & 1.3 & 61.9 & 4.6 \\
\hline SX108 & liq & 0 & 1 & \begin{tabular}{|c|}
0.3 \\
\end{tabular} & 85.1 & 1.6 & 1.2 & 85.8 & 6.6 \\
\hline SX109 & liq & 0 & 1 & \begin{tabular}{l|l}
0.3 \\
\end{tabular} & 85.1 & 1.6 & 1.2 & 85.8 & 6.6 \\
\hline SX111 & liq & 0 & 0 & 0.3 & 87.2 & 1.6 & 1.1 & 87.8 & 6.4 \\
\hline SX112 & liq & 0 & 1 & 0.3 & 85.1 & 1.6 & 1.2 & 85.8 & 6.6 \\
\hline SX114 & liq & 0 & 0 & \begin{tabular}{l|l}
0.3 \\
\end{tabular} & 87.2 & 1.6 & 1.1 & 87.8 & 6.4 \\
\hline $\mathrm{T} 101$ & liq & 1 & 1 & 0.1 & 60.9 & 0.4 & 0.5 & 61.9 & 1.6 \\
\hline T102 & liq & 0 & 1 & 0.2 & 85.1 & 1.1 & 0.8 & 85.8 & 4.4 \\
\hline T103 & liq & 0 & 1 & 0.2 & 85.1 & 1.1 & 0.8 & 85.8 & 4.4 \\
\hline T104 & liq & 1 & 1 & 0.1 & 60.9 & 0.4 & 0.5 & 61.9 & 1.6 \\
\hline T105 & liq & 0 & 0 & 0.3 & 87.2 & 1.6 & 1.1 & 87.8 & 6.4 \\
\hline T106 & liq & 0 & 0 & 0.3 & 87.2 & 1.6 & 1.1 & 87.8 & 6.4 \\
\hline T107 & liq & 4 & 6 & 0.1 & 37.4 & 0.2 & 0.3 & 38.9 & 0.7 \\
\hline
\end{tabular}




\begin{tabular}{|c|c|c|c|c|c|c|c|c|c|}
\hline \multirow[b]{2}{*}{ Tank } & \multirow[b]{2}{*}{ 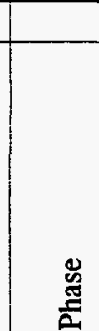 } & \multirow[b]{2}{*}{$\begin{array}{l}\text { Number } \\
\text { of } \\
\text { Samples } \\
\text { for Tank } \\
\text { Waste }\end{array}$} & \multirow[b]{2}{*}{$\begin{array}{l}\text { Number } \\
\text { of } \\
\text { Samples } \\
\text { in } \\
\text { SORWT } \\
\text { Group }\end{array}$} & \multicolumn{3}{|c|}{ Tank Median Estimate } & \multicolumn{3}{|c|}{ Worst $5 \%$ of the Waste } \\
\hline & & & & \begin{tabular}{|l} 
Tank \\
Median \\
Estimate \\
of TOC \\
wt $\%$ \\
(wet)
\end{tabular} & \begin{tabular}{|l|} 
\\
Relative \\
Standard \\
Deviation \\
on Median
\end{tabular} & $\begin{array}{l}95 \% \\
\text { Confidence } \\
\text { Bound on } \\
\text { Tank TOC } \\
\text { Estimate } \\
\text { wt\% TOC } \\
\text { (wet) }\end{array}$ & $\begin{array}{l}\text { Estimate } \\
\text { of Worst } \\
5 \% \text { of } \\
\text { Waste, } \\
\text { wt\% (wet) }\end{array}$ & $\begin{array}{l}\text { Relative } \\
\text { Standard } \\
\text { Deviation } \\
\text { on Worst } \\
5 \% \text { of the } \\
\text { Waste }\end{array}$ & $\begin{array}{l}95 \% \\
\text { Confidence } \\
\text { Bound on } \\
\text { Worst } 5 \% \text { of } \\
\text { the Waste }\end{array}$ \\
\hline T110 & liq & 0 & 1 & 0.3 & 85.1 & 1.4 & 1 & 85.8 & $\begin{array}{l}5.7 \\
\end{array}$ \\
\hline T111 & liq & 0 & 1 & 0.3 & 85.1 & 1.4 & 1 & 85.8 & 5.7 \\
\hline T112 & liq & $\overline{1}$ & 1 & 0.2 & 60.9 & 0.8 & 0.9 & 61.9 & 3.1 \\
\hline T201 & liq & $\overline{0}$ & 0 & 0.3 & 87.2 & 1.6 & 1.1 & 87.8 & 6.4 \\
\hline $\mathrm{T} 202$ & liq & 0 & 0 & 0.3 & 87.2 & 1.6 & 1.1 & 87.8 & 6.4 \\
\hline T203 & liq & 0 & 0 & 0.3 & 87.2 & 1.6 & 1.1 & 87.8 & 6.4 \\
\hline T204 & liq & 0 & 0 & 0.3 & 87.2 & 1.6 & 1.1 & 87.8 & 6.4 \\
\hline TX101 & liq & 0 & 0 & 0.3 & 87.2 & 1.6 & 1.1 & 87.8 & 6.4 \\
\hline TX102 & liq & 2 & 29 & 0.3 & 46.1 & 0.8 & 1.3 & 47.4 & 3.4 \\
\hline TX103 & liq & 3 & 3 & 0.3 & 42.4 & 0.6 & 1.1 & 43.8 & 2.6 \\
\hline TX104 & liq & 0 & 29 & 0.5 & 73.4 & 2 & 1.9 & 74.2 & 8.2 \\
\hline TX105 & liq & 1 & 29 & 0.6 & 55.2 & 1.8 & 2.4 & 56.3 & 7.4 \\
\hline TX106 & liq & 1 & 29 & 0.4 & 55.2 & 1.4 & 1.8 & 56.3 & 5.5 \\
\hline TX107 & liq & 0 & 29 & 0.5 & 73.4 & 2 & 1.9 & 74.2 & 8.2 \\
\hline TX109 & liq & 1 & 8 & 0.4 & 56.8 & 1.3 & 1.6 & 57.9 & 5.1 \\
\hline TX110 & liq & 3 & 8 & 0.3 & 41.1 & 0.8 & 1.4 & 42.5 & 3.2 \\
\hline TX111 & liq & 1 & 8 & 0.3 & 56.8 & 1.1 & 1.4 & 57.9 & 4.4 \\
\hline TX112 & liq & 1 & 8 & 0.3 & 56.8 & 0.9 & 1.1 & 57.9 & 3.5 \\
\hline TX113 & liq & 0 & 8 & 0.3 & 76.8 & 1.3 & 1.1 & 77.5 & 5.4 \\
\hline TX114 & liq & 1 & 8 & 0.2 & $\begin{array}{l}56.8 \\
\end{array}$ & 0.8 & 1 & \begin{tabular}{|l|}
57.9 \\
\end{tabular} & 3.1 \\
\hline TX115 & liq & 2 & 4 & 0.1 & 48 & 0.3 & 0.5 & 49.3 & 1.2 \\
\hline TX116 & liq & 1 & 8 & 0.2 & 56.8 & 0.5 & 0.7 & 57.9 & 2.2 \\
\hline TX117 & liq & 0 & 8 & 0.3 & 76.8 & 1.3 & 1.1 & 77.5 & 5.4 \\
\hline TX118 & liq & 6 & 7 & 0.2 & 411.2 & 25 & 4.2 & 434.2 & 25 \\
\hline TY102 & liq & 0 & 8 & 0.3 & 76.8 & 1.3 & 1.1 & 77.5 & 5.4 \\
\hline TY103 & liq & 1 & 4 & 0.2 & 59 & 0.6 & 0.8 & 60 & 2.6 \\
\hline TY104 & liq & 3 & 4 & 0.2 & 42 & 0.4 & 0.8 & \begin{tabular}{|l|}
43.4 \\
\end{tabular} & 1.8 \\
\hline U101 & liq & 0 & 1 & 0.3 & 85.1 & 1.6 & 1.2 & 85.8 & 6.6 \\
\hline U102 & liq & 0 & 4 & 0.4 & 80 & 2.2 & 1.8 & 80.8 & 8.9 \\
\hline U103 & liq & 0 & 4 & 0.4 & 80 & 2.2 & 1.8 & 80.8 & 8.9 \\
\hline U104 & liq & 0 & 0 & 0.3 & 87.2 & 1.6 & 1.1 & 87.8 & 6.4 \\
\hline U105 & liq & 0 & 0 & 0.3 & 87.2 & 1.6 & 1.1 & 87.8 & 6.4 \\
\hline U106 & liq & 1 & 4 & 1.6 & 58.4 & 5 & 6.2 & 59.4 & 20.5 \\
\hline U107 & liq & 0 & 0 & 0.3 & 87.2 & 1.6 & 1.1 & 87.8 & 6.4 \\
\hline U108 & liq & 0 & 0 & 0.3 & 87.2 & 1.6 & 1.1 & 87.8 & 6.4 \\
\hline U109 & liq & $\overline{0}$ & 0 & $\begin{array}{ll}0.3 \\
\end{array}$ & 87.2 & 1.6 & 1.1 & 87.8 & 6.4 \\
\hline U110 & liq & 0 & 0 & 0.3 & 87.2 & 1.6 & 1.1 & 87.8 & 6.4 \\
\hline U111 & liq & 1 & 4 & 1 & 58.4 & 3.3 & 4.2 & $\begin{array}{l}59.4 \\
\end{array}$ & 13.6 \\
\hline U112 & liq & 0 & 0 & 0.3 & 87.2 & 1.6 & 1.1 & 87.8 & 6.4 \\
\hline U201 & liq & 0 & 0 & 0.3 & 87.2 & 1.6 & 1.1 & 87.8 & 6.4 \\
\hline U202 & liq & 0 & 0 & 0.3 & 87.2 & 1.6 & 1.1 & 87.8 & 6.4 \\
\hline U203 & liq & 0 & 0 & \begin{tabular}{l|l}
0.3 \\
\end{tabular} & 87.2 & 1.6 & 1.1 & 87.8 & $\overline{6.4}$ \\
\hline U204 & liq & $\overline{0}$ & 0 & 0.3 & 87.2 & 1.6 & 1.1 & 87.8 & 6.4 \\
\hline
\end{tabular}




\begin{tabular}{|c|c|c|c|c|c|c|c|c|c|c|}
\hline \multirow[b]{2}{*}{ Tank } & \multirow[b]{2}{*}{ 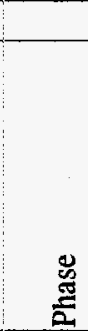 } & \multirow[b]{2}{*}{$\begin{array}{l}\text { Number } \\
\text { of } \\
\text { Samples } \\
\text { for Tank } \\
\text { Waste } \\
\end{array}$} & \multirow[b]{2}{*}{$\begin{array}{l}\text { Number } \\
\text { of } \\
\text { Samples } \\
\text { in } \\
\text { SORWT } \\
\text { Group } \\
\end{array}$} & \multicolumn{4}{|c|}{ Tank Median Estimate } & \multicolumn{3}{|c|}{ Worst $5 \%$ of the Waste } \\
\hline & & & & & $\begin{array}{l}\text { Tank } \\
\text { Median } \\
\text { Estimate } \\
\text { of TOC } \\
\text { wt\% } \\
\text { (wet) } \\
\end{array}$ & $\begin{array}{l}\text { Relative } \\
\text { Standard } \\
\text { Deviation } \\
\text { on Median }\end{array}$ & $\begin{array}{l}95 \% \\
\text { Confidence } \\
\text { Bound on } \\
\text { Tank TOC } \\
\text { Estimate } \\
\text { wt\% TOC } \\
\text { (wet) } \\
\end{array}$ & $\begin{array}{l}\text { Estimate } \\
\text { of Worst } \\
5 \% \text { of } \\
\text { Waste, } \\
\text { wt\% (wet) }\end{array}$ & $\begin{array}{l}\text { Relative } \\
\text { Standard } \\
\text { Deviation } \\
\text { on Worst } \\
5 \% \text { of the } \\
\text { Waste } \\
\end{array}$ & \begin{tabular}{|l|}
$95 \%$ \\
Confidence \\
Bound on \\
Worst $5 \%$ of \\
the Waste \\
\end{tabular} \\
\hline A101 & salt & 2 & 2 & 2 & 0.6 & 42.6 & 1.4 & 4.5 & 73.8 & 19.9 \\
\hline A102 & salt & 0 & 5 & 2 & 0.6 & 42.6 & 1.4 & 4.5 & 73.8 & 19.9 \\
\hline AX101 & salt & 0 & ) & 2 & 0.6 & 42.6 & 1.4 & 4.5 & 73.8 & 19.9 \\
\hline AX102 & salt & c & 5 & 0 & 0.6 & 39.1 & 1.2 & 4.3 & 71.9 & 18.3 \\
\hline AX103 & salt & 0 & 5 & 5 & 0.6 & 39.1 & 1.2 & 4.3 & 71.9 & 18.3 \\
\hline $\mathrm{B} 102$ & salt & $\mathrm{c}$ & ) & j & 0.6 & 39.1 & 1.2 & 4.3 & 71.9 & 18.3 \\
\hline B104 & salt & $\mathrm{c}$ & ) & ] & 0.6 & 39.1 & 1.2 & 4.3 & 71.9 & 18.3 \\
\hline B105 & salt & c & 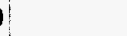 & 1 & 0.5 & 45.5 & 1.3 & 4 & 75.6 & 18 \\
\hline BX105 & salt & $\mathrm{c}$ & it & 0 & 0.6 & 39.1 & 1.2 & 4.3 & 71.9 & 18.3 \\
\hline BX110 & salt & c & 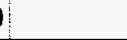 & 0 & 0.6 & 39.1 & 1.2 & 4.3 & 71.9 & 18.3 \\
\hline BX111 & salt & c & ) & 0 & 0.6 & 39.1 & 1.2 & 4.3 & 71.9 & 18.3 \\
\hline BY101 & salt & $\mathrm{c}$ & 5 & 4 & 0.7 & 37.9 & 1.4 & 5.1 & 71.2 & 21.1 \\
\hline BY102 & salt & c & 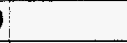 & 5 & 0.6 & 39.1 & 1.2 & 4.3 & 71.9 & 18.3 \\
\hline BY103 & salt & c & ) & 4 & 0.7 & 37.9 & 1.4 & 5.1 & 71.2 & 21.1 \\
\hline BY104 & salt & 4 & 1 & 4 & 0.7 & 37.9 & 1.4 & 5.1 & 71.2 & 21.1 \\
\hline BY105 & salt & c & ? & 4. & 0.7 & 37.9 & 1.4 & 5.1 & 71.2 & 21.1 \\
\hline BY106 & salt & $\bar{c}$ & T! & 4 & 0.7 & 37.9 & \begin{tabular}{|c|}
1.4 \\
\end{tabular} & 5.1 & 71.2 & 21.1 \\
\hline BY107 & salt & $\mathrm{c}$ & )! & 4 & 0.7 & 37.9 & \begin{tabular}{|l|}
1.4 \\
\end{tabular} & 5.1 & 71.2 & 21.1 \\
\hline BY108 & salt & c & t & 4 & 0.7 & 37.9 & \begin{tabular}{ll|}
1.4 \\
\end{tabular} & 5.1 & 71.2 & 21.1 \\
\hline BY109 & salt & c & 1 & 0 & 0.6 & 39.1 & 1.2 & 4.3 & 71.9 & 18.3 \\
\hline BY110 & salt & c & 5 & 4 & 0.7 & 37.9 & \begin{tabular}{|l|}
1.4 \\
\end{tabular} & \begin{tabular}{|l|}
5.1 \\
\end{tabular} & 71.2 & 21.1 \\
\hline BY111 & salt & C & 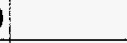 & 7 & 0.7 & 37.9 & 1.4 & 5.1 & 71.2 & 21.1 \\
\hline BY112 & salt & c & ) & 4 & 0.7 & 37.9 & 1.4 & 5.1 & 71.2 & 21.1 \\
\hline S101 & salt & c & ) & 8 & 0.4 & 31.8 & 0.8 & 3.3 & 68.2 & 12.9 \\
\hline $\mathbf{S} 102$ & salt & c & ) & 8 & 0.4 & 31.8 & 0.8 & \begin{tabular}{|l|}
3.3 \\
\end{tabular} & 68.2 & 12.9 \\
\hline S103 & salt & $\mathrm{c}$ & 5 & 8 & 0.4 & 31.8 & 0.8 & \begin{tabular}{|l|}
3.3 \\
\end{tabular} & 68.2 & 12.9 \\
\hline S105 & salt & c & ) & 8 & 0.4 & 31.8 & 0.8 & 3.3 & 68.2 & 12.9 \\
\hline S106 & salt & c & ) & 8 & 0.4 & 31.8 & 0.8 & 3.3 & 68.2 & 12.9 \\
\hline S107 & salt & c & )] & 8 & 0.4 & 31.8 & 0.8 & \begin{tabular}{|l|}
3.3 \\
\end{tabular} & 68.2 & 12.9 \\
\hline S108 & salt & c & ) & 8 & 0.4 & 31.8 & 0.8 & 3.3 & 68.2 & 12.9 \\
\hline S109 & salt & 1 & & 8 & 0.4 & 31.8 & 0.8 & 3.3 & 68.2 & 12.9 \\
\hline S110 & salt & c & & & 0.4 & 31.8 & 0.8 & \begin{tabular}{|l|}
3.3 \\
\end{tabular} & 68.2 & 12.9 \\
\hline S111 & salt & 3 & & 3 & 0.4 & 31.8 & 0.8 & \begin{tabular}{|l|}
3.3 \\
\end{tabular} & 68.2 & 12.9 \\
\hline $\mathbf{S 1 1 2}$ & salt & $\mathrm{c}$ & & 3 & 0.4 & 31.8 & 0.8 & \begin{tabular}{|l|}
3.3 \\
\end{tabular} & 68.2 & 12.9 \\
\hline SX101 & salt & ( & & 3 & 0.4 & 31.8 & 0.8 & 3.3 & 68.2 & 12.9 \\
\hline SX102 & salt & 2 & & 3 & 0.4 & 31.8 & 0.8 & 3.3 & 68.2 & 12.9 \\
\hline SX103 & salt & 1 & & 3 & 0.4 & 31.8 & 0.8 & 3.3 & 68.2 & 12.9 \\
\hline SX104 & salt & c & it & 3 & 0.4 & 31.8 & 0.8 & 3.3 & 68.2 & 12.9 \\
\hline SX105 & salt & c & & 8 & 0.4 & 31.8 & \begin{tabular}{|c|}
0.8 \\
\end{tabular} & 3.3 & 68.2 & 12.9 \\
\hline SX106 & salt & ( & & $8 !$ & 0.4 & 31.8 & 0.8 & \begin{tabular}{|l|}
3.3 \\
\end{tabular} & 68.2 & 12.9 \\
\hline TX102 & salt & 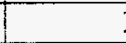 & & 8 & 0.4 & 31.8 & 0.8 & \begin{tabular}{|l|}
3.3 \\
\end{tabular} & 68.2 & 12.9 \\
\hline TX104 & salt & 8 & & 8 & 0.4 & 31.8 & 0.8 & \begin{tabular}{|l|}
3.3 \\
\end{tabular} & 68.2 & 12.9 \\
\hline TX105 & salt & ( & & 8 & 0.4 & 31.8 & $\begin{array}{ll}0.8 \\
\end{array}$ & 3.3 & 68.2 & 12.9 \\
\hline
\end{tabular}




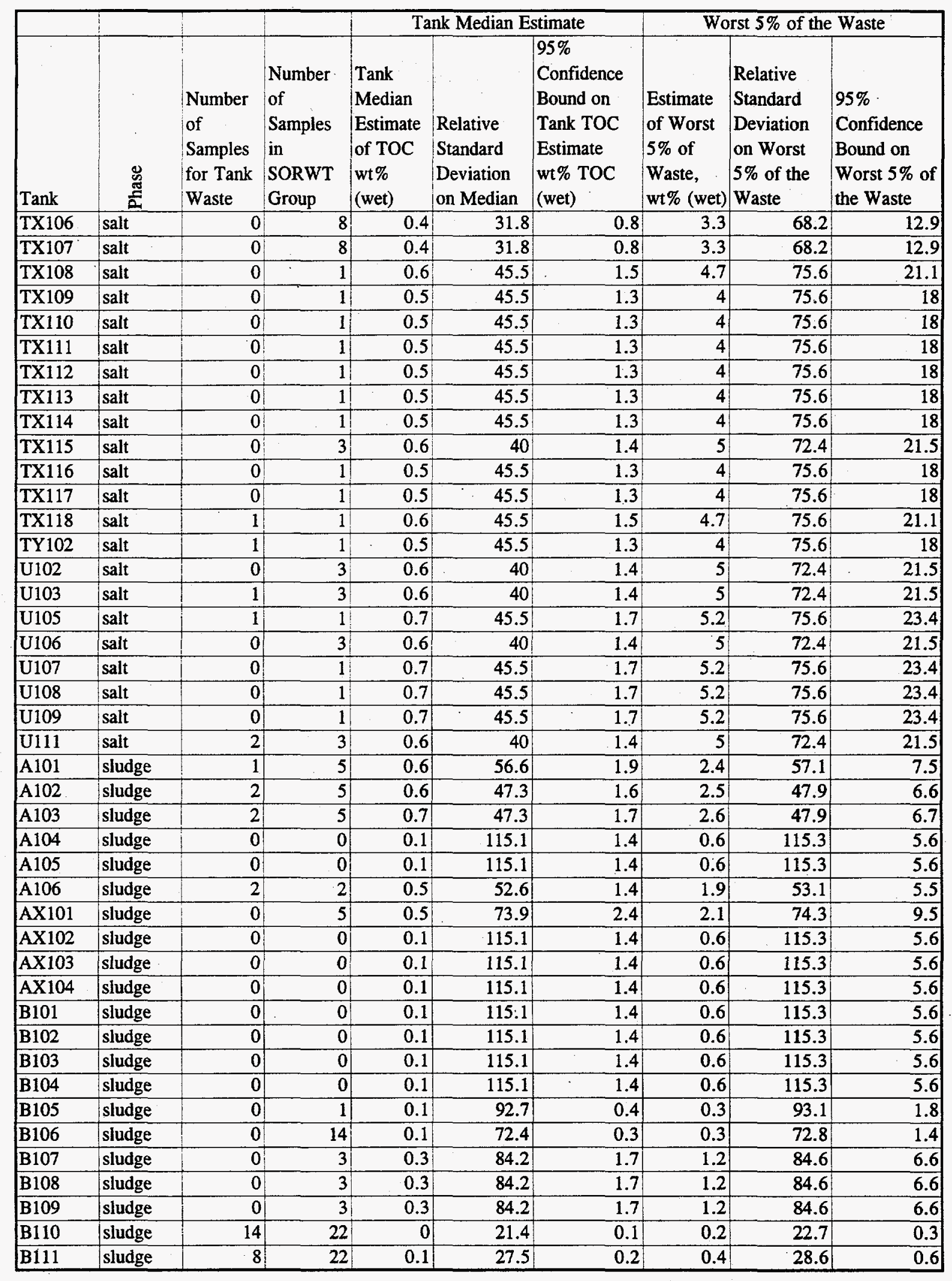




\begin{tabular}{|c|c|c|c|c|c|c|c|c|c|}
\hline \multirow[b]{2}{*}{ Tank } & \multirow[b]{2}{*}{ 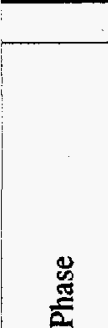 } & \multirow[b]{2}{*}{$\begin{array}{l}\text { Number } \\
\text { of } \\
\text { Samples } \\
\text { for Tank } \\
\text { Waste }\end{array}$} & \multirow[b]{2}{*}{$\begin{array}{l}\text { Number } \\
\text { of } \\
\text { Samples } \\
\text { in } \\
\text { SORWT } \\
\text { Group }\end{array}$} & \multicolumn{3}{|c|}{ Tank Median Estimate } & \multicolumn{3}{|c|}{ Worst $5 \%$ of the Waste } \\
\hline & & & & \begin{tabular}{|l|} 
Tank \\
Median \\
Estimate \\
of TOC \\
wt $\%$ \\
(wet) \\
(wet
\end{tabular} & \begin{tabular}{|l|} 
\\
Relative \\
Standard \\
Deviation \\
on Median \\
\end{tabular} & $\begin{array}{l}95 \% \\
\text { Confidence } \\
\text { Bound on } \\
\text { Tank TOC } \\
\text { Estimate } \\
\text { wt\% TOC } \\
\text { (wet) } \\
\end{array}$ & $\begin{array}{l}\text { Estimate } \\
\text { of Worst } \\
5 \% \text { of } \\
\text { Waste, } \\
\text { wt\% (wet) }\end{array}$ & $\begin{array}{l}\text { Relative } \\
\text { Standard } \\
\text { Deviation } \\
\text { on Worst } \\
5 \% \text { of the } \\
\text { Waste }\end{array}$ & $\begin{array}{l}95 \% \\
\text { Confidence } \\
\text { Bound on } \\
\text { Worst } 5 \% \text { of } \\
\text { the Waste }\end{array}$ \\
\hline B112 & sludge & $\mathbf{0}$ & \begin{tabular}{|r|}
22 \\
\end{tabular} & 0.1 & $\begin{array}{r}71.4 \\
\end{array}$ & $\begin{array}{r}0.3 \\
\end{array}$ & 0.3 & 71.8 & 1.2 \\
\hline B201 & sludge & 0 & 17 & 0.2 & 72.3 & 1 & 0.9 & 72.7 & 3.9 \\
\hline $\mathrm{B} 202$ & sludge & 15 & 17 & 0.2 & 424.4 & 25 & 7.6 & 430.2 & 25 \\
\hline B203 & sludge & 0 & 17 & 0.2 & 72.3 & 1 & 0.9 & 72.7 & 3.9 \\
\hline B204 & sludge & 1 & 17 & 0.2 & 55.6 & 0.5 & 0.7 & 56.2 & 2.1 \\
\hline BX101 & sludge & 0 & 5 & 0.2 & 76.2 & 1.1 & 0.9 & 76.5 & 4.2 \\
\hline BX102 & sludge & 0 & 5 & 0.2 & 76.2 & 1.1 & 0.9 & 76.5 & 4.2 \\
\hline BX103 & sludge & 0 & 5 & 0.2 & 76.2 & 1.1 & 0.9 & 76.5 & 4.2 \\
\hline BX104 & sludge & 3 & 5 & 0.3 & 42 & 0.6 & 1 & 42.7 & 2.4 \\
\hline BX105 & sludge & 2 & 5 & 0.2 & 48.2 & 0.6 & 1 & 48.8 & 2.6 \\
\hline BX106 & sludge & 0 & 5 & 0.2 & 76.2 & 1.1 & 0.9 & 76.5 & 4.2 \\
\hline BX107 & sludge & 9 & 14 & 0.1 & 26.2 & 0.1 & 0.3 & 27.3 & 0.4 \\
\hline BX108 & sludge & 0 & 5 & 0.2 & 76.2 & 1.1 & 0.9 & 76.5 & 4.2 \\
\hline BX109 & sludge & 0 & 5 & 0.2 & 76.2 & 1.1 & 0.9 & 76.5 & 4.2 \\
\hline BX110 & sludge & 2 & 3 & 0 & 49.6 & 0.1 & 0.2 & 50.2 & 0.5 \\
\hline BX111 & sludge & 1 & 3 & 0.1 & 60 & 0.2 & 0.2 & 60.5 & 0.8 \\
\hline $\mathrm{BX} 112$ & sludge & 3 & 3 & 0.4 & 44.4 & 1 & 1.6 & 45.1 & 3.9 \\
\hline BY101 & sludge & 0 & 0 & 0.1 & 115.1 & 1.4 & 0.6 & 115.3 & 5.6 \\
\hline BY103 & sludge & 0 & 0 & 0.1 & 115.1 & 1.4 & 0.6 & 115.3 & 5.6 \\
\hline BY104 & sludge & 0 & 0 & 0.1 & 115.1 & 1.4 & 0.6 & 115.3 & 5.6 \\
\hline BY105 & sludge & 0 & 0 & 0.1 & 115.1 & 1.4 & 0.6 & 115.3 & 5.6 \\
\hline BY106 & sludge & 0 & 0 & $\begin{array}{ll}0.1 \\
\end{array}$ & 115.1 & 1.4 & 0.6 & 115.3 & 5.6 \\
\hline BY107 & sludge & 0 & 0 & 0.1 & 115.1 & 1.4 & 0.6 & 115.3 & 5.6 \\
\hline BY108 & sludge & 0 & 0 & 0.1 & 115.1 & 1.4 & 0.6 & 115.3 & 5.6 \\
\hline BY 109 & sludge & 0 & 0 & 0.1 & 115.1 & 1.4 & 0.6 & 115.3 & 5.6 \\
\hline BY110 & sludge & 0 & 0 & 0.1 & 115.1 & 1.4 & 0.6 & 115.3 & 5.6 \\
\hline BY111 & sludge & 0 & 0 & 0.1 & 115.1 & 1.4 & 0.6 & 115.3 & 5.6 \\
\hline BY112 & sludge & 0 & 0 & 0.1 & 115.1 & 1.4 & 0.6 & 115.3 & 5.6 \\
\hline $\mathrm{C} 101$ & sludge & 0 & 5 & 0.2 & 76.2 & 1.1 & 0.9 & 76.5 & 4.2 \\
\hline $\mathrm{Cl02}$ & sludge & 0 & 0 & 0.1 & 115.1 & 1.4 & 0.6 & 115.3 & 5.6 \\
\hline $\mathrm{C} 103$ & sludge & 2 & 4 & 0.3 & 48.7 & 0.7 & 1 & 49.2 & 2.8 \\
\hline C104 & sludge & 1 & 1 & 0.3 & 67.9 & 1.2 & 1.2 & 68.3 & 4.6 \\
\hline $\mathrm{C} 105$ & sludge & 1 & 1 & 0.1 & 67.9 & 0.4 & 0.4 & 68.3 & 1.7 \\
\hline C106 & sludge & 2 & 4 & 0.2 & 48.7 & 0.5 & 0.8 & 49.2 & 2.1 \\
\hline C107 & sludge & 0 & 0 & 0.1 & 115.1 & 1.4 & 0.6 & 115.3 & 5.6 \\
\hline C108 & sludge & 0 & 38 & 0.2 & 67.8 & 0.7 & 0.7 & 68.2 & 2.7 \\
\hline $\mathrm{C} 109$ & sludge & 6 & 38 & 0.2 & 30.6 & 0.5 & 1 & 31.5 & 1.9 \\
\hline C110 & sludge & 5 & 14 & 0.1 & 33.7 & 0.2 & 0.3 & 34.5 & 0.6 \\
\hline C111 & sludge & 0 & 38 & 0.2 & 67.8 & 0.7 & 0.7 & 68.2 & 2.7 \\
\hline $\mathrm{C} 112$ & sludge & 17 & 38 & 0.3 & 19.4 & 0.4 & 1.2 & 20.8 & 1.8 \\
\hline $\mathrm{C} 201$ & sludge & 1 & 1 & 0.2 & 67.9 & 0.7 & 0.7 & 68.3 & 2.8 \\
\hline $\mathrm{C} 202$ & sludge & 0 & 1 & 0.2 & 92.7 & 1.1 & 0.7 & 93.1 & 4.3 \\
\hline $\mathrm{C} 203$ & sludge & 0 & 1 & 0.2 & 92.7| & 1.1 & 0.7 & 93.1 & 4.3 \\
\hline
\end{tabular}




\begin{tabular}{|c|c|c|c|c|c|c|c|c|c|}
\hline \multirow[b]{2}{*}{ Tank } & \multirow[b]{2}{*}{$\begin{array}{l}\text { 岕 } \\
\text { 兑 }\end{array}$} & \multirow[b]{2}{*}{$\begin{array}{l}\text { Number } \\
\text { of } \\
\text { Samples } \\
\text { for Tank } \\
\text { Waste }\end{array}$} & \multirow[b]{2}{*}{$\begin{array}{l}\text { Number } \\
\text { of } \\
\text { Samples } \\
\text { in } \\
\text { SORWT } \\
\text { Group } \\
\end{array}$} & \multicolumn{3}{|c|}{ Tank Median Estimate } & \multicolumn{3}{|c|}{ Worst $5 \%$ of the Waste } \\
\hline & & & & $\begin{array}{l}\text { Tank } \\
\text { Median } \\
\text { Estimate } \\
\text { of TOC } \\
\text { wt\% } \\
\text { (wet) }\end{array}$ & \begin{tabular}{|l|} 
\\
Relative \\
Standard \\
Deviation \\
on Median \\
\end{tabular} & $\begin{array}{l}95 \% \\
\text { Confidence } \\
\text { Bound on } \\
\text { Tank TOC } \\
\text { Estimate } \\
\text { wt\% TOC } \\
\text { (wet) }\end{array}$ & $\begin{array}{l}\text { Estimate } \\
\text { of Worst } \\
5 \% \text { of } \\
\text { Waste, } \\
\text { wt\% (wet) }\end{array}$ & $\begin{array}{l}\text { Relative } \\
\text { Standard } \\
\text { Deviation } \\
\text { on Worst } \\
5 \% \text { of the } \\
\text { Waste }\end{array}$ & $\begin{array}{l}95 \% \\
\text { Confidence } \\
\text { Bound on } \\
\text { Worst } 5 \% \text { of } \\
\text { the Waste }\end{array}$ \\
\hline $\mathrm{C} 204$ & sludge & 0 & 1 & 0.2 & 92.7 & 1.1 & \begin{tabular}{|r|}
0.7 \\
\end{tabular} & 93.1 & 4.3 \\
\hline S101 & sludge & 0 & 0 & 0.1 & 115.1 & 1.4 & 0.6 & 115.3 & 5.6 \\
\hline $\mathbf{S 1 0 2}$ & sludge & 0 & 0 & 0.1 & 115.1 & 1.4 & 0.6 & 115.3 & 5.6 \\
\hline $\mathbf{S 1 0 3}$ & sludge & 0 & 0 & 0.1 & 115.1 & 1.4 & 0.6 & 115.3 & 5.6 \\
\hline S104 & sludge & 11 & 11 & 0.2 & 24.5 & 0.3 & 0.6 & 25.6 & 1 \\
\hline S105 & sludge & 0 & 0 & 0.1 & 115.1 & 1.4 & 0.6 & 115.3 & 5.6 \\
\hline S106 & sludge & 0 & 0 & 0.1 & 115.1 & 1.4 & 0.6 & 115.3 & 5.6 \\
\hline S107 & sludge & 0 & 0 & 0.1 & 115.1 & 1.4 & 0.6 & 115.3 & 5.6 \\
\hline S108 & sludge & 0 & 0 & 0.1 & 115.1 & 1.4 & 0.6 & 115.3 & 5.6 \\
\hline S109 & sludge & 0 & 0 & 0.1 & 115.1 & 1.4 & 0.6 & 115.3 & 5.6 \\
\hline $\mathbf{S 1 1 0}$ & sludge & 0 & 0 & 0.1 & 115.1 & 1.4 & 0.6 & 115.3 & 5.6 \\
\hline S111 & sludge & 0 & 0 & 0.1 & 115.1 & 1.4 & 0.6 & 115.3 & 5.6 \\
\hline $\mathbf{S 1 1 2}$ & sludge & 0 & 0 & 0.1 & 115.1 & 1.4 & 0.6 & 115.3 & 5.6 \\
\hline SX101 & sludge & 0 & 0 & 0.1 & 115.1 & 1.4 & 0.6 & 115.3 & 5.6 \\
\hline SX102 & sludge & 0 & 0 & 0.1 & 115.1 & 1.4 & 0.6 & 115.3 & 5.6 \\
\hline SX103 & sludge & 0 & 0 & 0.1 & 115.1 & 1.4 & 0.6 & 115.3 & 5.6 \\
\hline SX104 & sludge & 0 & 0 & 0.1 & 115.1 & 1.4 & 0.6 & 115.3 & 5.6 \\
\hline SX105 & sludge & 0 & 0 & 0.1 & 115.1 & 1.4 & 0.6 & 115.3 & 5.6 \\
\hline SX106 & sludge & 0 & 0 & 0.1 & 115.1 & 1.4 & 0.6 & 115.3 & 5.6 \\
\hline SX107 & sludge & 0 & 11 & 0.2 & 79.4 & 0.8 & 0.6 & 79.8 & 3 \\
\hline SX108 & sludge & 0 & 11 & 0.2 & 79.4 & 0.8 & 0.6 & 79.8 & 3 \\
\hline SX109 & sludge & 0 & 11 & 0.2 & 79.4 & 0.8 & 0.6 & 79.8 & 3 \\
\hline SX110 & sludge & 0 & 0 & 0.1 & 115.1 & 1.4 & 0.6 & 115.3 & 5.6 \\
\hline SX111 & sludge & 0 & 0 & 0.1 & 115.1 & 1.4 & 0.6 & 115.3 & 5.6 \\
\hline SX112 & sludge & 0 & 11 & 0.2 & 79.4 & 0.8 & 0.6 & 79.8 & 3 \\
\hline SX113 & sludge & 0 & 0 & 0.1 & 115.1 & 1.4 & 0.6 & 115.3 & 5.6 \\
\hline SX114 & sludge & 0 & 0 & 0.1 & 115.1 & 1.4 & 0.6 & 115.3 & 5.6 \\
\hline SX115 & sludge & 0 & 11 & 0.2 & 79.4 & 0.8 & 0.6 & 79.8 & 3 \\
\hline T101 & sludge & 0 & 0 & 0.1 & 115.1 & 1.4 & 0.6 & 115.3 & 5.6 \\
\hline T102 & sludge & 0 & 0 & 0.1 & 115.1 & 1.4 & 0.6 & 115.3 & 5.6 \\
\hline $\mathrm{T} 103$ & sludge & 0 & 0 & 0.1 & 115.1 & 1.4 & 0.6 & 115.3 & 5.6 \\
\hline T104 & sludge & 6 & 6 & 0.1 & 32.6 & 0.1 & 0.2 & 33.5 & 0.5 \\
\hline T105 & sludge & 0 & 32 & 0.1 & 78 & 0.5 & 0.4 & 78.4 & 1.8 \\
\hline T106 & sludge & 0 & 32 & 0.1 & 78 & 0.5 & 0.4 & 78.4 & 1.8 \\
\hline T107 & sludge & 15 & 38 & 0.1 & 20.5 & 0.1 & 0.3 & 21.9 & 0.5 \\
\hline T108 & sludge & 0 & 14 & 0.1 & 72.4 & 0.3 & 0.3 & 72.8 & 1.4 \\
\hline T109 & sludge & 0 & 0 & 0.1 & 115.1 & 1.4 & 0.6 & 115.3 & 5.6 \\
\hline T110 & sludge & 0 & 8 & 0.2 & 80.2 & 1.2 & 0.9 & 80.6 & 4.8 \\
\hline T111 & sludge & 8 & 8 & 0.3 & 28.5 & 0.5 & 1.1 & 29.5 & 2.1 \\
\hline T112 & sludge & 0 & 8 & 0.2 & 80.2 & 1.2 & 0.9 & 80.6 & 4.8 \\
\hline T201 & sludge & 0 & 17 & 0.2 & 72.3 & 1 & 0.9 & 72.7 & 3.9 \\
\hline $\mathrm{T} 202$ & sludge & 0 & 17 & 0.2 & 72.3 & 1 & 0.9 & 72.7 & 3.9 \\
\hline T203 & sludge & 0 & 17 & 0.2 & 72.3 & 1 & 0.9 & 72.7 & 3.9 \\
\hline
\end{tabular}




\begin{tabular}{|c|c|c|c|c|c|c|c|c|c|}
\hline \multirow[b]{2}{*}{ Tank } & \multirow[b]{2}{*}{ 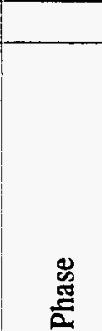 } & \multirow[b]{2}{*}{$\begin{array}{l}\text { Number } \\
\text { of } \\
\text { Samples } \\
\text { for Tank } \\
\text { Waste }\end{array}$} & \multirow[b]{2}{*}{$\begin{array}{l}\text { Number } \\
\text { of } \\
\text { Samples } \\
\text { in } \\
\text { SORWT } \\
\text { Group }\end{array}$} & \multicolumn{3}{|c|}{ Tank Median Estimate } & \multicolumn{3}{|c|}{ Worst $5 \%$ of the Waste } \\
\hline & & & & $\begin{array}{l}\text { Tank } \\
\text { Median } \\
\text { Estimate } \\
\text { of TOC } \\
\text { wt } \% \\
\text { (wet) }\end{array}$ & $\begin{array}{l}\text { Relative } \\
\text { Standard } \\
\text { Deviation } \\
\text { on Median }\end{array}$ & \begin{tabular}{|l}
$95 \%$ \\
Confidence \\
Bound on \\
Tank TOC \\
Estimate \\
wt\% TOC \\
(wet)
\end{tabular} & $\begin{array}{l}\text { Estimate } \\
\text { of Worst } \\
5 \% \text { of } \\
\text { Waste, } \\
\text { wt\% (wet) }\end{array}$ & $\begin{array}{l}\text { Relative } \\
\text { Standard } \\
\text { Deviation } \\
\text { on Worst } \\
5 \% \text { of the } \\
\text { Waste }\end{array}$ & $\begin{array}{l}95 \% \\
\text { Confidence } \\
\text { Bound on } \\
\text { Worst } 5 \% \text { of } \\
\text { the Waste }\end{array}$ \\
\hline T204 & sludge & 1 & 17 & 0.3 & \begin{tabular}{|l}
55.6 \\
\end{tabular} & 1 & 1.3 & \begin{tabular}{|r}
6.2 \\
\end{tabular} & 4 \\
\hline TX101 & sludge & 0 & $\begin{array}{c}0 \\
0\end{array}$ & 0.1 & 115.1 & 1.4 & 0.6 & 115.3 & 5.6 \\
\hline $\mathrm{TX103}$ & sludge & 0 & 0 & 0.1 & 115.1 & 1.4 & 0.6 & 115.3 & 5.6 \\
\hline TY101 & sludge & 2 & 2 & 0 & 52.6 & 0 & 0 & 53.1 & 0.1 \\
\hline TY103 & sludge & 6 & 18 & 0.1 & 31.2 & 0.1 & 0.3 & 32.1 & 0.6 \\
\hline TY104 & sludge & 12 & 18 & 0.2 & 23 & 0.4 & 0.9 & 24.2 & 1.5 \\
\hline TY105 & sludge & 1 & 7 & 0.1 & 58 & 0.4 & 0.4 & 58.5 & 1.4 \\
\hline TY106 & sludge & 6 & 7 & 0.1 & 31.9 & 0.3 & 0.6 & 32.7 & 1.1 \\
\hline U101 & sludge & 0 & 11 & 0.2 & 79.4 & 0.8 & 0.6 & 79.8 & 3 \\
\hline U102 & sludge & 0 & 1 & 0.3 & 92.7 & 2 & 1.2 & 93.1 & 7.8 \\
\hline U103 & sludge & 1 & 1 & 0.4 & 67.9 & 1.6 & 1.6 & 68.3 & 6.2 \\
\hline U104 & sludge & 0 & 0 & 0.1 & 115.1 & 1.4 & 0.6 & 115.3 & 5.6 \\
\hline U105 & sludge & 0 & 0 & 0.1 & 115.1 & 1.4 & 0.6 & 115.3 & 5.6 \\
\hline U106 & sludge & 0 & 1 & 0.3 & 92.7 & 2 & 1.2 & 93.1 & 7.8 \\
\hline U107 & sludge & 0 & 0 & 0.1 & 115.1 & 1.4 & 0.6 & 115.3 & 5.6 \\
\hline U108 & sludge & 0 & 0 & 0.1 & 115.1 & 1.4 & 0.6 & 115.3 & 5.6 \\
\hline U109 & sludge & 0 & 0 & 0.1 & 115.1 & 1.4 & 0.6 & 115.3 & 5.6 \\
\hline U110 & sludge & 32 & 32 & 0.1 & 14.6 & 0.1 & \begin{tabular}{|c|}
0.3 \\
\end{tabular} & 16.4 & 0.5 \\
\hline U111 & sludge & 0 & 1 & 0.3 & 92.7 & 2 & 1.2 & 93.1 & 7.8 \\
\hline U112 & sludge & 0 & 0 & 0.1 & 115.1 & 1.4 & 0.6 & 115.3 & 5.6 \\
\hline U201 & sludge & 0 & 0 & 0.1 & 115.1 & 1.4 & 0.6 & 115.3 & 5.6 \\
\hline U202 & sludge & 0 & 0 & 0.1 & 115.1 & 1.4 & 0.6 & 115.3 & 5.6 \\
\hline U203 & sludge & 0 & 0 & 0.1 & 115.1 & 1.4 & 0.6 & 115.3 & $\overline{5.6}$ \\
\hline U204 & sludge & 0 & 0 & 0.1 & 115.1 & 1.4 & 0.6 & 115.3 & 5.6 \\
\hline
\end{tabular}




\section{Appendix K}

TOC Inventory Estimates for 149 Single-Shell Tanks 


\begin{tabular}{|c|c|c|c|c|c|c|c|c|c|c|}
\hline tank & $\begin{array}{l}\text { Total } \\
\text { Liquid } \\
\text { Volume } \\
\text { K Gal } \\
\end{array}$ & $\begin{array}{l}\text { Liquid } \\
\text { Amount, } \\
\text { MT } \\
\end{array}$ & $\begin{array}{l}\text { Median } \\
\text { TOC, \%, } \\
\text { (wet basis) } \\
\end{array}$ & \begin{tabular}{|l|} 
Inventory \\
Total \\
Organic \\
Carbon, \\
MT \\
\end{tabular} & tank & $\begin{array}{l}\text { Total } \\
\text { Liquid } \\
\text { Volume } \\
\text { K Gal } \\
\end{array}$ & $\begin{array}{l}\text { Liquid } \\
\text { Amount, } \\
\text { MT }\end{array}$ & $\begin{array}{l}\text { Median } \\
\text { TOC, \%, } \\
\text { (wet basis) }\end{array}$ & \begin{tabular}{|l|} 
Inventory \\
Total \\
Organic \\
Carbon, \\
MT \\
\end{tabular} & \\
\hline A101 & 413 & 2141 & 0.90 & 19 & S111 & 205 & 1063 & 0.40 & 4 & \\
\hline $\mathrm{Al} 02$ & 6 & 31 & 0.40 & 0 & $\$ 112$ & 110 & 570 & 0.50 & 3 & \\
\hline $\mathrm{Al03}$ & 20 & 103 & 0.60 & 1 & SX101 & 146 & 757 & 0.20 & 2 & \\
\hline A105 & 4 & 21 & 0.30 & 0 & $\$ \times 102$ & 183 & 948 & 0.50 & 5 & \\
\hline A106 & 7 & 36 & 0.10 & 0 & SX103 & 233 & 1208 & 0.50 & 6 & \\
\hline AX101 & 320 & 1659 & 0.80 & 13 & SX104 & 201 & 1042 & 0.30 & 3 & \\
\hline $\mathrm{AX102}$ & 17 & 88 & 1.10 & 1 & SX105 & 261 & 1354 & 0.50 & 7 & \\
\hline AX103 & 36 & 187 & 0.80 & 1 & SX106 & 255 & 1322 & 2.00 & 26 & \\
\hline $\mathrm{B} 101$ & 6 & 31 & 0.30 & 0 & SX107 & 5 & 26 & 0.30 & 0 & \\
\hline $\mathrm{B} 102$ & 4 & 21 & 0.30 & 0 & SX108 & 5 & 26 & 0.30 & 0 & \\
\hline B104 & 47 & 243 & 0.30 & 1 & SX109 & 10 & 52 & 0.30 & 0 & \\
\hline B105 & 23 & 119 & 0.30 & 0 & SX111 & 7 & 36 & 0.30 & 0 & \\
\hline $\mathrm{B} 106$ & 7 & 36 & 0.20 & 0 & SX112 & 3 & 15 & 0.30 & 0 & \\
\hline B107 & 13 & 67 & 0.30 & 0 & SX114 & 14 & 73 & 0.30 & 0 & \\
\hline B108 & 4 & 21 & 0.30 & 0 & T101 & 17 & 88 & 0.10 & 0 & \\
\hline B109 & 8 & 41 & 0.30 & 0 & $\mathrm{~T} 102$ & 13 & 67 & 0.20 & 0 & \\
\hline B110 & 23 & 119 & 0.30 & 0 & T103 & 4 & 21 & 0.20 & 0 & \\
\hline B111 & 22 & 114 & 0.30 & 0 & T104 & 50 & 260 & 0.10 & 0 & \\
\hline B112 & 3 & 15 & 0.30 & 0 & T105 & 23 & 119 & 0.30 & 0 & \\
\hline B201 & 4 & 21 & 0.30 & 0 & T106 & 2 & 11 & 0.30 & $0 !$ & \\
\hline $\mathrm{B} 202$ & 3 & 15 & 0.30 & 0 & T107 & 22 & 114 & 0.10 & 0 & \\
\hline B203 & 6 & 31 & 0.30 & 0 & T110 & 42 & 217 & 0.30 & 1 & \\
\hline B204 & 6 & 31 & 0.30 & 0 & T111 & 51 & 264 & 0.30 & 1 & \\
\hline $\mathrm{BX101}$ & 1 & 5 & 0.40 & 0 & $\mathrm{~T} 112$ & 7 & 36 & 0.20 & 0 & \\
\hline$\overline{B X 102}$ & 4 & 21 & 0.40 & 0 & T201 & 4 & 21 & 0.30 & 0 & \\
\hline $\mathrm{BX} 103$ & 4 & 21 & 0.40 & 0 & T202 & 2 & 11 & 0.30 & 0 & \\
\hline BX104 & 33 & 171 & 0.50 & 1 & T203 & 4 & 21 & 0.30 & 0 & \\
\hline $\mathrm{B} \times 105$ & 11 & 57 & 0.50 & 0 & $\mathrm{~T} 204$ & 4 & 21 & 0.30 & 0 & \\
\hline BX106 & 15 & 78 & 0.40 & 0 & TX101 & 5 & 26 & 0.30 & 0 & \\
\hline BX107 & 30 & 155 & 0.20 & 0 & TX102 & 22 & 114 & 0.30 & 0 & \\
\hline $\mathrm{BX} 108$ & 1 & 5 & 0.40 & 0 & TX103 & 15 & 78 & 0.30 & 0 & \\
\hline BX109 & 13 & 67 & 0.30 & 0 & TX104 & 15 & 78 & 0.50 & 0 & \\
\hline $\mathrm{BX} 110$ & 15 & 78 & 0.30 & 0 & TX105 & 20 & 103 & 0.60 & 1 & \\
\hline $\mathrm{BX} 112$ & 8 & 41 & 0.30 & 0 & TX106 & 10 & 52 & 0.40 & 0 & \\
\hline BY101 & 5 & 26 & 0.20 & 0 & TX107 & 2 & 11 & 0.50 & 0 & \\
\hline BY 102 & 41 & 213 & 0.20 & 0 & TX109 & 10 & 52 & 0.40 & 0 & \\
\hline BY103 & 160 & 830 & 0.20 & 2 & TX110 & 15 & 78 & 0.30 & 0 & \\
\hline BY104 & 18 & 93 & 0.20 & 0 & TX111 & 9 & 47 & 0.30 & 0 & \\
\hline BY105 & 192 & 995 & 0.20 & 2 & TX112 & 24 & 125 & 0.30 & 0 & \\
\hline BY106 & 235 & 1219 & 0.20 & 2 & TX113 & 16 & 83 & 0.30 & 0 & \\
\hline BY 107 & 25 & 129 & 0.30 & 0 & TX114 & 15 & 78 & 0.20 & 0 & \\
\hline BY108 & 9 & 47 & 0.20 & 0 & TX115 & 19 & 99 & 0.10 & 0 & \\
\hline BY109 & 78 & 404 & 0.30 & 1 & TX116 & 23 & 119 & 0.20 & 0 & \\
\hline$B Y 110$ & 9 & 47 & 0.20 & 0 & TX117 & 8 & 41 & 0.30 & 0 & \\
\hline BYI12 & 8 & 41 & 0.20 & D) & TX118 & 27 & 140 & 0.20 & 0 & \\
\hline $\mathrm{Cl01}$ & 3 & 15 & 0.40 & 0 & TY102 & 14 & 73 & 0.30 & 0 & \\
\hline $\mathrm{C} 102$ & 37 & 192 & 0.30 & II & TY103 & 5 & 26 & 0.20 & 0 & \\
\hline $\mathrm{C} 103$ & 133 & 690 & 0.60 & $4 !$ & TY104 & 15 & 78 & 0.20 & 0 & \\
\hline $\mathrm{Cl} 104$ & 11 & 57 & 0.50 & 0 & U101 & 3 & 15 & 0.30 & 0 & \\
\hline C105 & 11 & 57 & 0.30 & 0 & U102 & 144 & 746 & 0.40 & 3 & \\
\hline $\mathrm{Cl06}$ & 48 & 249 & 0.30 & 1 & U103 & 189 & 980 & 0.40 & 4 & \\
\hline $\mathrm{C} 107$ & 26 & 135 & 0.20 & 0 & U104 & 7 & 36 & 0.30 & 0 & \\
\hline C109 & 4 & 21 & 0.20 & 0 & U105 & 179 & 928 & 0.30 & 3 & \\
\hline C110 & 7 & 36 & 0.10 & 0 & U106 & 83 & 430 & 1.60 & 7 & \\
\hline $\mathrm{CI12}$ & 32 & 166 & 0.20 & 0 & U10? & 178 & 923 & 0.30 & 3 & \\
\hline$S 101$ & 96 & 498 & 0.50 & 2 & U108 & 196 & 1016 & 0.30 & 3 & \\
\hline S102 & 230 & 1193 & 0.90 & I1 & U109 & 182 & 944 & 0.30 & 3 & \\
\hline S103 & 102 & 529 & 0.50 & 3 & U110 & 15 & 78 & 0.30 & 0 & \\
\hline S104 & 29 & 150 & 0.30 & 0 & U111 & 122 & 632 & 1.00 & 6 & \\
\hline S105 & 35 & 181 & 0.50 & 1 & U112 & 4 & 21 & 0.30 & 0 & \\
\hline S106 & 190 & 985 & 0.50 & 5 & U201 & 1 & 5 & 0.30 & 0 & \\
\hline $\mathbf{S 1 0 7}$ & 59 & 306 & 0.50 & 2 & U202 & 1 & 5 & 0.30 & 0 & \\
\hline S108 & 127 & 658 & 0.50 & 3 & U203 & 1 & 5 & 0.30 & 01 & \\
\hline $\mathbf{S 1 0 9}$ & 141 & 731 & 0.50 & 4 & U204 & 1 & 5 & 0.30 & 0 & \\
\hline $\mathbf{S} 110$ & 110 & 570 & 0.70 & 4 & \multicolumn{3}{|c|}{ MT of TOC in Liquid Phase } & & 187 & \\
\hline
\end{tabular}

K.1 




\section{K. 2}




\begin{tabular}{|c|c|c|c|c|c|c|c|c|c|c|}
\hline $\begin{array}{l}\text { Sludge } \\
\text { tank }\end{array}$ & \begin{tabular}{|l} 
Total \\
Sludge \\
Volume \\
K Gal
\end{tabular} & \begin{tabular}{|l|} 
Sludge \\
Amount, \\
MT
\end{tabular} & \begin{tabular}{|} 
Median \\
TOC, \%, \\
(wet basis)
\end{tabular} & \begin{tabular}{|l|} 
Inventory \\
Total \\
Organic \\
Carbon, \\
MT \\
\end{tabular} & \begin{tabular}{|l} 
Sludge \\
tank
\end{tabular} & $\begin{array}{l}\text { Total } \\
\text { Sludge } \\
\text { Voiume } \\
\text { K Gal }\end{array}$ & \begin{tabular}{|l|} 
Sludge \\
Amount, \\
MT
\end{tabular} & $\begin{array}{l}\text { Median } \\
\text { Toc, \%, } \\
\text { (wet basis) }\end{array}$ & \begin{tabular}{|l|} 
Inventory \\
Total \\
Organic \\
Carbon, \\
MT \\
\end{tabular} & \\
\hline $\mathrm{A} 101$ & $\begin{array}{ll}1 & 3 \\
\end{array}$ & 16 & 0.6 & 0.096 & S101 & 224 & 1339 & 0.1 & 1.339 & \\
\hline $\mathrm{A102}$ & 15 & 82 & 0.6 & 0.492 & $\$ \$ 102$ & 4 & 22 & 0.1 & 0.022 & \\
\hline $\mathrm{Al03}$ & 366 & 2009 & 0.7 & 14.063 & $\$ 103$ & 10 & $\cdot 55$ & 0.1 & 0.055 & \\
\hline $\mathrm{A} 104$ & 28 & 154 & 0.1 & 0.154 & $\$ 104$ & 293 & 1608 & 0.2 & 3.216 & \\
\hline A105 & 19 & 104 & 0.1 & 0.104 & S105 & 2 & 11 & 0.1 & 0.011 & \\
\hline A106 & 125 & 686 & 0.5 & 3.43 & $\$ 106$ & 28 & 154 & 0.1 & 0.154 & \\
\hline AXIO1 & 3 & 16 & 0.5 & 0.08 & $\$ 107$ & 293 & 1608 & 0.1 & 1.608 & \\
\hline $\mathrm{AX102}$ & 7 & 38 & 0.1 & 0.038 & 5108 & 4 & 22 & 0.1 & 0.022 & \\
\hline AX103 & 2 & 11 & 0.1 & 0.011 & S109 & 13 & 71 & 0.1 & 0.071 & \\
\hline Ax104 & 7 & 38 & 0.1 & 0.038 & $\$ 110$ & 131 & 719 & 0.1 & 0.719 & \\
\hline B101 & 113 & 620 & 0.1 & 0.62 & S111 & 139 & 763 & 0.1 & 0.763 & \\
\hline B102 & 18 & 99 & 0.1 & 0.099 & S112 & 5 & 27 & 0.1 & 0.027 & \\
\hline B103 & 59 & 324 & 0.1 & 0.324 & SX101 & 112 & 615 & 0.1 & 0.615 & \\
\hline B104 & 301 & 1652 & 0.1 & 1.652 & SX102 & 117 & 642 & 0.1 & 0.642 & \\
\hline B105 & 40 & .220 & 0.1 & 0.22 & $5 \times 103$ & 115 & 631 & 0.1 & 0.631 & \\
\hline B106 & 116 & 637 & 0.1 & 0.637 & SX104 & 136 & 746 & 0.1 & 0.746 & \\
\hline B107 & 164 & 900 & 0.3 & 2.7 & SX105 & 73 & 401 & 0.1 & 0.401 & \\
\hline B108 & 94 & 516 & 0.3 & 1.548 & SX106 & 12 & 66 & 0.1 & 0.066 & \\
\hline B109 & 127 & 697 & 0.3 & 2.091 & SX107 & 104 & 571 & 0.2 & 1.142 & \\
\hline B110 & 245 & 1345 & 0 & 0 & SX108 & 87 & 477 & 0.2 & 0.954 & \\
\hline B111 & 236 & 1295 & 0.1 & 1.295 & SX109 & 250 & 1372 & 0.2 & 2.744 & \\
\hline B112 & 30 & 165 & 0.1 & 0.165 & $\mathbf{S X} 110$ & 62 & 340 & 0.1 & 0.34 & \\
\hline B201 & 28 & 154 & 0.2 & 0.308 & SX111 & 125 & 686 & 0.1 & 0.686 & \\
\hline B202 & 27 & 148 & 0.2 & 0.296 & SX112 & 92 & 505 & 0.2 & 1.01 & \\
\hline B203 & 50 & 274 & 0.2 & 0.548 & SX113 & 26 & 143 & 0.1 & 0.143 & \\
\hline B204 & 49 & 269 & 0.2 & 0.538 & SX114 & 181 & 993 & 0.1 & 0.993 & \\
\hline BX101 & 42 & 231 & 0.2 & 0.462 & SX115. & 12 & 66 & 0.2 & 0.132 & \\
\hline $\mathrm{BX} 102$ & 96 & 527 & 0.2 & 1.054 & T101 & 101 & 554 & 0.1 & 0.554 & \\
\hline $\mathrm{BX} 103$ & 62 & 340 & 0.2 & 0.68 & T102 & 19 & 104 & 0.1 & 0.104 & \\
\hline BX104 & 96 & 527 & 0.3 & 1.581 & T103 & 23 & 126 & 0.1 & 0.126 & \\
\hline BX105 & 43 & 236 & 0.2 & 0.472 & T104 & 442 & 2426 & 0.1 & 2.426 & \\
\hline BX106 & 31 & 170 & 0.2 & 0.34 & T105 & 98 & 538 & 0.1 & 0.538 & \\
\hline BX107 & 344 & 1888 & 0.1 & 1.888 & T106 & 19 & 104 & 0.1 & 0.104 & \\
\hline BX108 & 26 & 143 & 0.2 & 0.286 & T107 & 171 & 938 & 0.1 & 0.938 & \\
\hline BX109 & 193 & 1059 & 0.2 & 2.118 & T108 & 44 & 241 & 0.1 & 0.241 & \\
\hline BX110 & 189 & 1037 & 0 & 0 & T109 & 58 & 318 & 0.1 & 0.318 & \\
\hline $\mathrm{BX} 111$ & 68 & 373 & 0.1 & 0.373 & T110 & 376 & 2064 & 0.2 & 4.128 & \\
\hline BX112 & 164 & 900 & 0.4 & 3.6 & $\mathrm{~T} 111$ & 456 & 2503 & 0.3 & 7.509 & \\
\hline BY101 & 109 & 598 & 0.1 & 0.598 & T112 & 60 & 329 & 0.2 & 0.658 & \\
\hline BY103 & 5 & 27 & 0.1 & 0.027 & $\mathrm{~T} 201$ & 28 & 154 & 0.2 & 0.308 & \\
\hline BY104 & 40 & 220 & 0.1 & 0.22 & $\mathrm{~T} 202$ & 21 & 115 & 0.2 & 0.23 & \\
\hline BY105 & 44 & 241 & 0.1 & 0.241 & $\mathrm{~T} 203$ & 35 & 192 & 0.2 & 0.384 & \\
\hline BY106 & 95 & 521 & 0.1 & 0.521 & $\mathrm{~T} 204$ & 38 & 209 & 0.3 & 0.627 & \\
\hline BY107 & 60 & 329 & 0.1 & 0.329 & TX101 & 84 & 461 & 0.1 & 0.461 & \\
\hline BY108 & 154 & 845 & 0.1 & 0.845 & TX103 & 157 & 862 & 0.1 & 0.862 & \\
\hline BY109 & 83 & 456 & 0.1 & 0.456 & TY 101 & 118 & 648 & 0 & 0 & \\
\hline BY110 & 103 & 565 & 0.1 & 0.565 & TY103 & 162 & 889 & 0.1 & 0.889 & \\
\hline BY111 & 21 & 115 & 0.1 & 0.115 & TY104 & 43 & 236 & 0.2 & 0.472 & \\
\hline BY112 & 5 & 27 & 0.1 & 0.027 & TY105 & 231 & 1268 & 0.1 & 1.268 & \\
\hline C101 & 88 & 483 & 0.2 & 0.966 & TY106 & 17 & 93 & 0.1 & 0.093 & \\
\hline C102 & 423 & 2322 & 0.1 & 2.322 & U101 & 22 & 121 & 0.2 & 0.242 & \\
\hline C103 & 62 & 340 & 0.3 & 1.02 & U102 & 43 & 236 & 0.3 & 0.708 & \\
\hline C104 & 295 & 1619 & 0.3 & 4.857 & U103 & 32 & 176 & 0.4 & 0.704 & \\
\hline $\bar{C} 105$ & 150 & 823 & 0.1 & 0.823 & U104 & 122 & 670 & 0.1 & 0.67 & \\
\hline C106 & 197 & 1081 & 0.2 & 2.162 & U105 & 32 & 176 & 0.1 & 0.176 & \\
\hline C107 & 275 & 1509 & 0.1 & 1.509 & U106 & 26 & 143 & 0.3 & 0.429 & \\
\hline C108 & 66 & 362 & 0.2 & 0.724 & U107 & 15 & 82 & 0.1 & 0.082 & \\
\hline $\mathrm{C}_{109}$ & 62 & 340 & 0.2 & 0.68 & U108. & 29 & 159 & 0.1 & 0.159 & \\
\hline C110 & 187 & 1026 & 0.1 & 1.026 & U109 & 48 & 263 & 0.1 & 0.263 & \\
\hline C111 & 57 & 313 & 0.2 & 0.626 & U110 & 186 & 1021 & 0.1 & 1.021 & \\
\hline $\mathrm{C} 112$ & 104 & 571 & 0.3 & 1.713 & U111 & 26 & 143 & 0.3 & 0.429 & \\
\hline C201 & 2 & 11 & 0.2 & 0.022 & U112 & 45 & 247 & 0.1 & 0.247 & \\
\hline $\mathrm{C} 202$ & 1 & 5 & 0.2 & 0.01 & U201 & 4 & 22 & 0.1 & 0.022 & \\
\hline $\mathrm{C}_{203}$ & 5 & 27 & 0.2 & 0.054 & U202 & 4 & 22 & 0.1 & 0.022 & \\
\hline $\mathrm{C}_{204}$ & 3 & 16 & 0.2 & 0.032 & U203 & 2 & 11 & 0.1 & 0.011 & \\
\hline
\end{tabular}




\begin{tabular}{|c|c|c|c|c|}
\hline $\begin{array}{l}\text { Sludge } \\
\text { ank }\end{array}$ & \begin{tabular}{|l} 
Total \\
Sludge \\
Volume \\
K Gal \\
\end{tabular} & $\begin{array}{l}\text { Sludge } \\
\text { Amount, } \\
\text { MT }\end{array}$ & $\begin{array}{l}\text { Median } \\
\text { TOC, \%, } \\
\text { (wet basis) }\end{array}$ & $\begin{array}{l}\text { Inventory } \\
\text { Total } \\
\text { Organic } \\
\text { Carbon, } \\
\text { MT }\end{array}$ \\
\hline $\mathrm{U} 204$ & 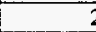 & 11 & 0.1 & 0.011 \\
\hline \multicolumn{3}{|l|}{ Total S1 } & & 115 \\
\hline
\end{tabular}

K.4 
Appendix L

Saltcake Waste Moisture Grouping 
Appendix L , Moisture Groups for Saltcake Wastes

\begin{tabular}{|c|c|c|c|}
\hline $\begin{array}{c}\text { Moisture Group } \\
\text { Number }\end{array}$ & Ventilation & $\begin{array}{c}\text { Redox or Non Redox } \\
\text { Waste }\end{array}$ & Jet Pumped Indicator \\
\hline 1 & Active & Non-Redox Waste & Jet-Pumped \\
\hline 2 & Active & Redox Waste & Jet-Pumped \\
\hline 3 & Active & Non-Redox Waste & Not Jet Pumped \\
\hline 4 & Active & Redox Waste & Not Jet Pumped \\
\hline 5 & Passive & Non-Redox Waste & Jet-Pumped \\
\hline 6 & Passive & Redox Waste & Jet-Pumped \\
\hline 7 & Passive & Non-Redox Waste & Not Jet Pumped \\
\hline 8 & Passive & Redox Waste & Not Jet Pumped \\
\hline
\end{tabular}




\begin{tabular}{|c|c|c|c|c|c|}
\hline Tank No. & Ventilation & $\begin{array}{c}\text { Redox or Non Redox } \\
\text { Waste } \\
\end{array}$ & Jet Pumped Indicator & $\begin{array}{c}\text { Volume of Saltcake } \\
\text { (Kgal) from Hanlon, 1994 }\end{array}$ & Moisture Group \\
\hline A-101 & Passive & NON-R & Not Jet Pumped & 950 & 7 \\
\hline A-102 & Passive & NON-R & Not Jet Pumped & 22 & 7 \\
\hline $\mathrm{AX}-101$ & Passive & NON-R & Not Jet Pumped & 745 & 7 \\
\hline$A X-102$ & Passive & NON-R & Not Jet Pumped & 29 & 7 \\
\hline $\mathrm{AX}-103$ & Passive & NON-R & Not Jet Pumped & 110 & 7 \\
\hline B-102 & Passive & NON-R & Not Jet Pumped & 10 & 7 \\
\hline B-104 & Passive & NON-R & Not Jet Pumped & 69 & 7 \\
\hline B-105 & Passive & NON-R & Not Jet Pumped & 266 & 7 \\
\hline BX-105 & Passive & NON-R & Not Jet Pumped & 3 & 7 \\
\hline$B X-110$ & Passive & NON-R & Not Jet Pumped & 9 & 7 \\
\hline BX-111 & Passive & NON-R & Not Jet Pumped & 143 & 7 \\
\hline BY-101 & Passive & NON-R & Jet Pumped & 278 & 5 \\
\hline BY-102 & Passive & NON-R & Not Jet Pumped & 341 & 7 \\
\hline BY-103 & Passive & NON-R & Not Jet Pumped & 395 & 7 \\
\hline BYY-104 & Passive & NON-R & Jet Pumped & 366 & 5 \\
\hline BY-105 & Passive & NON-R & Not Jet Pumped & 459 & 7 \\
\hline BYY-106 & Passive & NON-R & Not Jet Pumped & 547 & 7 \\
\hline BY-103 & Passive & NON-R & Jet Pumped & 206 & 5 \\
\hline $13 Y-108$ & Passive & NON-R & Jet Pumped & 74 & 5 \\
\hline BY-109 & Passive & NON-R & Not Jet Pumped & 340 & 7 \\
\hline$B Y-110$ & Passive & NON-R & Jet Pumped & 295 & 5 \\
\hline BY-111 & Passive & NON-R & Jet Pumped & 438 & 5 \\
\hline $13 \mathrm{Y}-112$ & Passive & NON-R & Jet Pumped & 286 & 5 \\
\hline S-101 & Passive & $\mathbf{R}$ & Not Jet Pumped & 171 & 8 \\
\hline S-102 & Passive & $\mathbf{R}$ & Not Jet Pumped & 545 & 8 \\
\hline S-103 & Passive & $\mathrm{R}$ & Not Jet Pumped & 221 & 8 \\
\hline S-105 & Passive & $\mathbf{R}$ & Jet Pumped & 454 & 6 \\
\hline S-106 & Passive & $\mathrm{R}$ & Not Jet Pumped & 447 & 8 \\
\hline S-107 & Passive & $\mathbf{R}$ & Not Jet Pumped & 69 & 8 \\
\hline S-108 & Passive & $\mathrm{R}$ & Not Jet Pumped & 600 & 8 \\
\hline S-109 & Passive & $\mathrm{R}$ & Not Jet Pumped & 555 & 8 \\
\hline S-110 & Passive & $\mathrm{R}$ & Not Jet Pumped & 259 & 8 \\
\hline S-111 & Passive & $\mathrm{R}$ & Not Jet Pumped & 447 & 8 \\
\hline 5.112 & Passive & $\mathrm{R}$ & Not Jet Pumped & 518 & 8 \\
\hline$\$ X-101$ & Active & $\mathbf{R}$ & Not Jet Pumped & 343 & 4 \\
\hline SX-102 & Active & $\mathrm{R}$ & Not Jet Pumped & 426 & 4 \\
\hline $\mathbf{S X}-103$ & Active & $\mathbf{R}$ & Not Jet Pumped & 536 & 4 \\
\hline$\$ X-104$ & Active & $\mathbf{R}$ & Not Jet Pumped & 478 & 4 \\
\hline SX-105 & Active & $\mathrm{R}$ & Not Jet Pumped & 610 & 4 \\
\hline sX-106 & Active & $\mathrm{R}$ & Not Jet Pumped & 465 & 4 \\
\hline IX-102 & Passive & $\mathbf{R}$ & Jet Pumped & 217 & 6 \\
\hline TX-104 & Passive & $\mathbf{R}$ & Not Jet Pumped & 64 & 8 \\
\hline TX-105 & Passive & $\mathbf{R}$ & Jet Pumped & 609 & 6 \\
\hline TX-106 & Passive & $\mathbf{R}$ & Jet Pumped & 453 & 6 \\
\hline TX-107 & Passive & $\mathrm{R}$ & Not Jet Pumped & 35 & 8 \\
\hline TX-108 & Passive & NON-R & Jet Pumped & 134 & 5 \\
\hline TX-109 & Passive & NON-R & Jet Pumped & 384 & 5 \\
\hline TX-110 & Passive & NON-R & Jet Pumped & 462 & 5 \\
\hline TX-111 & Passive & NON-R & Jet Pumped & 370 & 5 \\
\hline TX-112 & Passive & NON-R & Jet Pumped & 649 & 5 \\
\hline TX-113 & Passive & NON-R & Jet Pumped & 607 & 5 \\
\hline $\mathrm{TX}-114$ & Passive & NON-R & Jet Pumped & 535 & 5 \\
\hline TX-115 & Passive & NON-R & Jet Pumped & 640 & 5 \\
\hline TX-116 & Passive & NON-R & Jet Pumped & 631 & 5 \\
\hline TX-117 & Passive & NON-R & Jet Pumped & 626 & 5 \\
\hline TX-118 & Passive & NON-R & Jet Pumped & 347 & 5 \\
\hline $\mathrm{TY} \cdot 102$ & Passive & NON-R & Not Jet Pumped & 64 & $?$ \\
\hline $\mathrm{U}-102$ & Passive & NON-R & Not Jet Pumped & 313 & 7 \\
\hline UI-103 & Passive & NON-R & Not Jet Pumped & 423 & 7 \\
\hline $\mathrm{U}-105$ & Passive & $\mathbf{R}$ & Not Jet Pumped & 349 & 8 \\
\hline$U-106$ & Passive & NON-R & Not Jet Purnped & 185. & 7 \\
\hline $\mathrm{U}-107$ & Passive & $\mathbf{R}$ & Not Jet Pumped & 360 & 8 \\
\hline U-108 & Passive & $\mathbf{R}$ & Not Jet Pumped & 415 & 8 \\
\hline$U=109$ & Passive & $\mathbf{R}$ & Not Jet Pumped & 396 & 8 \\
\hline U-111 & Passive & NON-R & Not Jet Pumped & 303 & 7 \\
\hline
\end{tabular}


Appendix M

SORWT Group Data for 149 Single-Shell Tanks 


\begin{tabular}{|c|c|c|c|c|c|c|}
\hline $\begin{array}{l}\text { Tank } \\
\text { No. }\end{array}$ & $\begin{array}{c}\text { SORWT } \\
\text { Group }\end{array}$ & $\begin{array}{c}\text { Primary } \\
\text { Waste } \\
\text { Type }\end{array}$ & $\begin{array}{l}\text { Secondary } \\
\text { Waste Type } \\
\end{array}$ & $\begin{array}{c}\text { Tertiary } \\
\text { Waste Type }\end{array}$ & $\begin{array}{c}\text { Other } \\
\text { Waste Type }\end{array}$ & $\begin{array}{c}\text { Watch List Status, } \\
\text { G= Gas Generation, } \\
\text { O= Organics, } \\
\text { F= Ferrocyanide, } \\
\text { H= High Heat, } \\
\text { N= Not Watchlist Tank }\end{array}$ \\
\hline A-101 & IX & DSSF & NCPLX & EVAP & & $\mathrm{G}$ \\
\hline A-102 & IX & DSSF & NCPLX & EVAP & & $\mathrm{N}$ \\
\hline A-103 & IX & DSSF & NCPLX & EVAP & & $\mathrm{N}$ \\
\hline A-104 & XXXK & SLUICE & $\mathbf{P}$ & $\mathrm{H} 2 \mathrm{O}$ & B & $\mathrm{H}$ \\
\hline A-105 & $\mathrm{XXXJ}$ & $\mathrm{P}$ & IX & . & & $\mathrm{H}$ \\
\hline A-106 & $\mathrm{XXXA}$ & CCPLX & NCPLX & EVAP & B & $\mathrm{N}$ \\
\hline AX-101 & IX & DSSF & NCPLX & EVAP & & G \\
\hline AX-102 & XXVIII & CCPLX & DSSF & EVAP & & $\mathrm{N}$ \\
\hline AX-103 & XXVIII & CCPLX & DSSF & EVAP & & $\mathrm{G}$ \\
\hline AX-104 & XXXI & EVAP & NCPLX & $\mathrm{P}$ & & $\mathrm{N}$ \\
\hline B-101 & XVIII & $\mathrm{CW}$ & $\mathrm{EB}$ & $\mathrm{BL}$ & & $\mathbf{N}$ \\
\hline B-102 & XVIII & $\mathrm{CW}$ & EB & $\mathrm{BL}$ & IX & $\mathrm{N}$ \\
\hline B-103 & XVIII & $\mathrm{CW}$ & EB & IX & MIX & $\mathrm{O}$ \\
\hline B-104 & $\mathrm{XXXH}$ & $2 \mathrm{C}$ & EB & TBP & $1 \mathrm{C}$ & $\mathbf{N}$ \\
\hline B-105 & II & EB & $1 \mathrm{C}$ & & & $\mathrm{N}$ \\
\hline B-106 & $\mathrm{XI}$ & $1 \mathrm{C}$ & TBP & HLO & MIX & $\mathrm{N}$ \\
\hline B-107 & XII & $1 \mathrm{C}$ & EB & $\mathrm{CW}$ & TBP & $\mathbf{N}$ \\
\hline B-108 & XII & $1 \mathrm{C}$ & EB & $\mathrm{CW}$ & IX-TBP & $\mathrm{N}$ \\
\hline B-109 & XII & $1 \mathrm{C}$ & EB & $\mathrm{CW}$ & IX & $\mathrm{N}$ \\
\hline B-110 & $\mathrm{XV}$ & $2 \mathrm{C}$ & 6-May & FP & IX & $\mathrm{N}$ \\
\hline B-111 & $\mathrm{XV}$ & $2 \mathrm{C}$ & 6-May & FP & IX & $\mathbf{N}$ \\
\hline B-112 & $\mathrm{XV}$ & $2 C$ & 6-May & FP & EB-ITS & $\mathbf{N}$ \\
\hline B-201 & $\mathrm{V}$ & 224 & & & & $\mathrm{~N}$ \\
\hline B-202 & $\mathrm{V}$ & $\overline{224}$ & & & & $\mathrm{~N}$ \\
\hline B-203 & V & 224 & & & & $\mathrm{~N}$ \\
\hline B-204 & V & 224 & & & & $\mathrm{~N}$ \\
\hline BX-101 & IV & TBP & $\mathrm{CW}$ & $\mathrm{BL}$ & IX & $\mathrm{N}$ \\
\hline BX-102 & IV & TBP & $\mathrm{CW}$ & $\mathrm{BL}$ & DIA & $\bar{F}$ \\
\hline BX-103 & IV & TBP & $\mathrm{CW}$ & OWW & MIX & $\mathrm{N}$ \\
\hline BX-104 & IV & TBP & $\mathrm{CW}$ & IX & $\mathbf{R}$ & $\mathbf{N}$ \\
\hline BX-105 & IV & TBP & $\mathrm{CW}$ & IX & EB & $\mathrm{N}$ \\
\hline BX-106 & IV & TBP & $\mathrm{CW}$ & EB-IX & BL & $\mathrm{F}$ \\
\hline BX-107 & $\mathrm{XI}$ & $1 \mathrm{C}$ & TBP & $\mathrm{CW}$ & IX & $\mathrm{N}$ \\
\hline BX-108 & IV & TBP & $\mathrm{CW}$ & $1 \mathrm{C}$ & IX & $\mathrm{N}$ \\
\hline BX-109 & IV & TBP & $\mathrm{CW}$ & $1 \mathrm{C}$ & IX & $\mathrm{N}$ \\
\hline
\end{tabular}




\begin{tabular}{|c|c|c|c|c|c|c|}
\hline $\begin{array}{c}\text { Tank } \\
\text { No. }\end{array}$ & $\begin{array}{l}\text { SORWT } \\
\text { Group }\end{array}$ & $\begin{array}{c}\text { Primary } \\
\text { Waste } \\
\text { Type }\end{array}$ & $\begin{array}{l}\text { Secondary } \\
\text { Waste Type }\end{array}$ & $\begin{array}{c}\text { Tertiary } \\
\text { Waste Type }\end{array}$ & $\begin{array}{c}\text { Other } \\
\text { Waste Type }\end{array}$ & $\begin{array}{c}\text { Watch List Status, } \\
\text { G= Gas Generation, } \\
\text { O= Organics, } \\
\text { F= Ferrocyanide, } \\
\text { H= High Heat, } \\
\text { N= Not Watchlist Tank }\end{array}$ \\
\hline $\mathrm{BX}-110$ & XXIV & $1 \mathrm{C}$ & EB-ITS & $\mathrm{CW}$ & IX & $F$ \\
\hline $\mathrm{BX}-111$ & XXIV & $1 \mathrm{C}$ & EB-ITS & $\mathrm{CW}$ & IX & F \\
\hline $\mathrm{BX}-112$ & XII & $1 \mathrm{C}$ & $\mathrm{EB}$ & $\mathrm{CW}$ & IX & $\mathrm{N}$ \\
\hline BY-101 & III & TBP-F & EB-ITS & $\mathrm{CW}$ & $1 \mathrm{C}$ & $F$ \\
\hline BY-102 & XXI & TBP & EB-ITS & $\mathrm{CW}$ & $1 \mathrm{C}$ & $\mathbf{N}$ \\
\hline BY-103 & III & TBP-F & EB-ITS & $\mathrm{P}$ & CW-OWW & $\mathrm{F}$ \\
\hline BY-104 & III & TBP-F & EB-ITS & $\mathrm{CW}$ & IX & $F$ \\
\hline BY-105 & III & TBP-F & EB-ITS & $\mathrm{CW}$ & & $\mathrm{F}$ \\
\hline BY-106 & III & TBP-F & EB-ITS & $\mathrm{CW}$ & & $F$ \\
\hline BY -107 & III & TBP-F & EB-ITS & $\mathrm{CW}$ & & $\mathrm{F}$ \\
\hline BY-108 & III & TBP-F & EB-ITS & $1 \mathrm{C}$ & $\mathrm{CW}$ & $\mathrm{F}$ \\
\hline BY-109 & $\mathrm{XXI}$ & TBP & EB-ITS & $\mathrm{CW}$ & MW & $\mathrm{N}$ \\
\hline BY-110 & III & TBP-F & EB-ITS & $1 \mathrm{C}$ & $\mathrm{CW}$ & $\mathrm{F}$ \\
\hline BY-111 & III & TBP-F & EB-ITS & OWW & $\mathrm{CW}$ & $\mathrm{F}$ \\
\hline BY-112 & III & TBP-F & EB-ITS & $\mathrm{CW}$ & & $\mathrm{F}$ \\
\hline C-101 & IV & TBP & CW & $\mathbf{P}$ & OWW & $\mathrm{N}$ \\
\hline C-102 & XXXB & $\mathrm{CW}$ & TBP & OWW & & $\mathrm{N}$ \\
\hline$C-103$ & XXIII & SRS & SR-WASH & $\mathbf{P}$ & TBP-CW & $\mathrm{O}$ \\
\hline C-104 & $\mathrm{XXXC}$ & $\mathrm{CW}$ & OWW & SR-WASH & H SRS & $\mathrm{N}$ \\
\hline C-105 & $\mathrm{XXXD}$ & TBP & SR-WASH & $\mathrm{CW}$ & $\mathrm{P}$ & $\dot{\mathrm{H}}$ \\
\hline $\mathrm{C}-106$ & XXIII & SRS & SR-WASH & $\mathbf{P}$ & TBP & $\mathrm{H}$ \\
\hline C-107 & XXXE & $1 \mathrm{C}$ & SRS & $\mathrm{CW}$ & IX & $\mathrm{N}$ \\
\hline$C-108$ & VIII & TBP-F & $1 \mathrm{C}$ & $\mathrm{CW}$ & OWW & $F$ \\
\hline C-109 & VIII & TBP-F & $1 \mathrm{C}$ & $\mathrm{CW}$ & IX & $\mathrm{F}$ \\
\hline $\mathrm{C}-110$ & XI & $1 \mathrm{C}$ & TBP & OWW & EB-IX & $\mathrm{N}$ \\
\hline C-111 & VIII & TBP-F & $1 \mathrm{C}$ & $\mathrm{CW}$ & $\mathrm{HS}$ & $F$ \\
\hline $\mathrm{C}-112$ & VIII & TBP-F & $1 \mathrm{C}$ & $\mathrm{CW}$ & IX & $\mathrm{F}$ \\
\hline $\mathrm{C}-201$ & XIII & HS & & & & $\mathrm{N}$ \\
\hline $\mathrm{C}-202$ & XIII & $\mathrm{HS}$ & & & & $\mathrm{N}$ \\
\hline C-203 & XIII & $\mathrm{HS}$ & & & & $\mathrm{N}$ \\
\hline C-204 & XIII & $\mathrm{HS}$ & & & & $\mathrm{N}$ \\
\hline S-101 & I & $\mathrm{R}$ & EB & IX & MIX & $\mathrm{N}$ \\
\hline S-102 & $I$ & $\mathrm{R}$ & EB & DSSF & & $\mathrm{OG}$ \\
\hline S-103 & $\mathrm{I}$ & $\mathrm{R}$ & EB & DSSF & & $\mathrm{N}$ \\
\hline S-104 & VI & $\mathrm{R}$ & & & & $\mathrm{N}$ \\
\hline
\end{tabular}

M.2 


\begin{tabular}{|c|c|c|c|c|c|c|}
\hline $\begin{array}{c}\text { Tank } \\
\text { No. }\end{array}$ & $\begin{array}{c}\text { SORWT } \\
\text { Group }\end{array}$ & $\begin{array}{c}\text { Primary } \\
\text { Waste } \\
\text { Type }\end{array}$ & $\begin{array}{c}\text { Secondary } \\
\text { Waste Type }\end{array}$ & $\begin{array}{c}\text { Tertiary } \\
\text { Waste Type }\end{array}$ & $\begin{array}{c}\text { Other } \\
\text { Waste Type }\end{array}$ & $\begin{array}{c}\text { Watch List Status, } \\
\text { G= Gas Generation, } \\
\text { O= Organics, } \\
\text { F= Ferrocyanide, } \\
\text { H= High Heat, } \\
\text { N= Not Watchlist Tank }\end{array}$ \\
\hline S-105 & $\mathrm{I}$ & $\mathrm{R}$ & EB & & & $\mathrm{N}$ \\
\hline S-106 & I & $\mathrm{R}$ & EB & & & $\mathrm{N}$ \\
\hline S-107 & I & $\mathbf{R}$ & EB & $\mathrm{CW}$ & IX-MIX & $\mathrm{N}$ \\
\hline S-108 & I & $\mathbf{R}$ & $\mathrm{EB}$ & & & $\mathrm{N}$ \\
\hline S-109 & I & $\mathrm{R}$ & $\mathrm{EB}$ & & & $\mathbf{N}$ \\
\hline S-110 & I & $\mathbf{R}$ & EB & MIX & & $\mathrm{N}$ \\
\hline S-111 & I & $\mathrm{R}$ & EB & & & G \\
\hline S-112 & I & $\mathrm{R}$ & EB & & & G \\
\hline SX-101 & $\mathrm{I}$ & $\mathrm{R}$ & EB & RIX & & $G$ \\
\hline SX-102 & I & $\mathrm{R}$ & EB & RIX & & G \\
\hline SX-103 & I & $\mathrm{R}$ & EB & $\mathrm{CW}$ & OWW & G \\
\hline SX-104 & I & $\mathbf{R}$ & EB & RIX & & $\mathrm{G}$ \\
\hline SX-105 & I & $\mathrm{R}$ & EB & RIX & HLO & G \\
\hline SX-106 & I & $\mathbf{R}$ & EB & RIX & HLO-MX & OG \\
\hline SX-107 & VI & $\mathbf{R}$ & & & & $\mathrm{H}$ \\
\hline SX-108 & VI & $\mathrm{R}$ & & & & $\mathrm{H}$ \\
\hline SX-109 & VI & $\mathrm{R}$ & & & & GH \\
\hline SX-110 & XVI & $\mathrm{R}$ & RIX & MIX & & $\mathrm{H}$ \\
\hline SX-111 & $\mathrm{XVI}$ & $\mathbf{R}$ & RIX & & & $\mathrm{H}$ \\
\hline SX-112 & VI & $\mathrm{R}$ & & & & $\mathrm{H}$ \\
\hline SX-113 & XXIX & $\mathbf{R}$ & DIA & & & $\mathbf{N}$ \\
\hline SX-114 & XVI & $\mathbf{R}$ & RIX & EB & & $\mathrm{H}$ \\
\hline SX-115 & VI & $\mathrm{R}$ & & & & $\mathbf{N}$ \\
\hline $\mathrm{T}-101$ & $\mathrm{XIX}$ & $\mathrm{CW}$ & MIX & TBP-F & EVAP & $\mathrm{F}$ \\
\hline T-102 & XIX & $\mathrm{CW}$ & MIX & IX & & $\mathbf{N}$ \\
\hline T-103 & $\mathrm{XIX}$ & $\mathrm{CW}$ & MIX & & & $\mathbf{N}$ \\
\hline T-104 & XXXF & $1 \mathrm{C}$ & & & & $\mathbf{N}$ \\
\hline T-105 & XVII & $1 \mathrm{C}$ & $\mathrm{CW}$ & $2 \mathrm{C}$ & BL-IX & $\mathbf{N}$ \\
\hline T-106 & XVII & $1 \mathrm{C}$ & $\mathrm{CW}$ & $2 \mathrm{C}$ & MIX & $\mathrm{N}$ \\
\hline T-107 & VIII & TBP-F & $1 \mathrm{C}$ & $\mathrm{CW}$ & IX & $F$ \\
\hline T-108 & $\mathrm{XI}$ & $1 \mathrm{C}$ & TBP & EB & HLO & $\mathrm{N}$ \\
\hline T-109 & XXVI & TBP & EB & MIX & & $\mathbf{N}$ \\
\hline T-110 & XIV & $2 \mathrm{C}$ & 224 & & & G \\
\hline $\mathrm{T}-111$ & XIV & $2 \mathrm{C}$ & 224 & & & 0 \\
\hline T-112 & XIV & $2 \mathrm{C}$ & 224 & DW & MIX & $\mathrm{N}$ \\
\hline
\end{tabular}




\begin{tabular}{|c|c|c|c|c|c|c|}
\hline $\begin{array}{c}\text { Tank } \\
\text { No. }\end{array}$ & $\begin{array}{l}\text { SORWT } \\
\text { Group }\end{array}$ & $\begin{array}{c}\text { Primary } \\
\text { Waste } \\
\text { Type }\end{array}$ & $\begin{array}{l}\text { Secondary } \\
\text { Waste Type }\end{array}$ & $\begin{array}{c}\text { Tertiary } \\
\text { Waste Type }\end{array}$ & $\begin{array}{c}\text { Other } \\
\text { Waste Type }\end{array}$ & $\begin{array}{c}\text { Watch List Status, } \\
\text { G= Gas Generation, } \\
\text { O= Organics, } \\
\text { F= Ferrocyanide, } \\
\text { H= High Heat, } \\
\text { N= Not Watchlist Tank }\end{array}$ \\
\hline $\mathrm{T}-201$ & $\mathrm{~V}$ & 224 & +2 & & & $\mathrm{~N}$ \\
\hline $\mathrm{T}-202$ & $\mathrm{~V}$ & 224 & & & & $\mathrm{~N}$ \\
\hline $\mathrm{T}-203$ & $\mathrm{~V}$ & 224 & & & & $\mathrm{~N}$ \\
\hline $\mathrm{T}-204$ & $\mathrm{~V}$ & 224 & & & & $\mathrm{~N}$ \\
\hline TX-101 & XXXM & $\mathrm{R}$ & MIX & MIX & & $\mathrm{N}$ \\
\hline TX-102 & $I$ & $\mathrm{R}$ & EB & MIX & & $\mathrm{N}$ \\
\hline TX-103 & XXVI & TBP & $\mathrm{EB}$ & & & $\mathrm{N}$ \\
\hline TX-104 & I & $\mathrm{R}$ & EB & MIX & & $\mathrm{N}$ \\
\hline TX-105 & I & $\mathrm{R}$ & $\mathrm{EB}$ & MIX & & $\mathrm{O}$ \\
\hline TX-106 & $\bar{I}$ & $\bar{R}$ & $\mathrm{~EB}$ & MIX & & $\mathrm{N}$ \\
\hline TX-107 & I & $\mathrm{R}$ & EB & & & $\mathrm{N}$ \\
\hline TX-108 & XXII & EB & TBP & $\mathrm{R}$ & & $\mathrm{N}$ \\
\hline TX-109 & II & $\mathrm{EB}$ & $1 \mathrm{C}$ & TBP & & $\mathrm{N}$ \\
\hline TX-110 & II & EB & $1 \mathrm{C}$ & TBP & & $\mathrm{N}$ \\
\hline $\mathrm{TX}-111$ & II & $\mathrm{EB}$ & $1 \mathrm{C}$ & TBP & & $\mathbf{N}$ \\
\hline $\mathrm{TX}-112$ & II & $\mathrm{EB}$ & $1 \mathrm{C}$ & & & $\mathrm{N}$ \\
\hline TX-113 & II & EB & $1 \mathrm{C}$ & & & $\mathrm{N}$ \\
\hline TX-114 & II & EB & $1 \mathrm{C}$ & & & $\mathrm{N}$ \\
\hline TX-115 & VII & $\mathrm{EB}$ & $\mathrm{R}$ & $\mathrm{CW}$ & DW & $\mathrm{N}$ \\
\hline TX-116 & II & EB & $1 \mathrm{C}$ & & & $\mathrm{N}$ \\
\hline TX-117 & II & EB & $1 \mathrm{C}$ & & & $\mathrm{N}$ \\
\hline $\mathrm{TX}-118$ & XXII & $\mathrm{EB}$ & TBP & $\mathrm{CW}$ & $1 \mathrm{C}$ & $\mathrm{FO}$ \\
\hline TY-101 & $\mathrm{XXXG}$ & $1 \mathrm{C}-\mathrm{F}$ & EB & TBP & $\mathbf{R}$ & $F$ \\
\hline TY-102 & II & $\mathrm{EB}$ & $1 \mathrm{C}$ & MIX & & $\mathrm{N}$ \\
\hline TY -103 & XXVII & TBP & $1 \mathrm{C}-\mathrm{F}$ & $\mathrm{CW}$ & R-MIX & $F$ \\
\hline TY-104 & XXVII & TBP & $1 \mathrm{C}-\mathrm{F}$ & DW & MIX-R & $F$ \\
\hline $\mathrm{TY}-105$ & $\mathrm{XXV}$ & TBP & & & & $\mathrm{N}$ \\
\hline TY -106 & XXV & TBP & & & & $\mathrm{N}$ \\
\hline U-101 & VI & $\mathrm{R}$ & $\cdots$ & & & $\mathbf{N}$ \\
\hline U-102 & VII & $\mathrm{EB}$ & $\mathbf{R}$ & & & $\mathrm{N}$ \\
\hline U-103 & VII & EB & $\mathrm{R}$ & MIX & & $G$ \\
\hline U-104 & $\overline{X X I X}$ & $\mathrm{R}$ & DIA & & & $\mathrm{N}$ \\
\hline U-105 & $\mathrm{X}$ & EB & $\mathrm{CW}$ & $\mathbf{R}$ & & $\mathrm{G}$ \\
\hline U-106 & VII & EB & $\mathbf{R}$ & $\mathrm{BL}$ & $\mathrm{PL}$ & $\mathrm{O}$ \\
\hline U-107 & $\mathrm{X}$ & EB & $\mathrm{CW}$ & MIX & & 0 \\
\hline
\end{tabular}




\begin{tabular}{|c|c|c|c|c|c|c|}
\hline $\begin{array}{c}\text { Tank } \\
\text { No. }\end{array}$ & $\begin{array}{c}\text { SORWT } \\
\text { Group }\end{array}$ & $\begin{array}{c}\text { Primary } \\
\text { Waste } \\
\text { Type }\end{array}$ & $\begin{array}{c}\text { Secondary } \\
\text { Waste Type }\end{array}$ & $\begin{array}{c}\text { Tertiary } \\
\text { Waste Type }\end{array}$ & $\begin{array}{c}\text { Other } \\
\text { Waste Type }\end{array}$ & $\begin{array}{c}\text { Watch List Status, } \\
\text { G= Gas Generation, } \\
\text { O= Organics, } \\
\text { F= Ferrocyanide, } \\
\text { H= High Heat, } \\
\text { N= Not Watchlist Tank }\end{array}$ \\
\hline U-108 & $\mathrm{X}$ & $\mathrm{EB}$ & $\mathrm{CW}$ & MIX & & $\mathrm{G}$ \\
\hline U-109 & $\mathrm{X}$ & EB & $\mathrm{CW}$ & $\mathrm{R}$ & & $\mathrm{G}$ \\
\hline U-110 & XVII & $1 \mathrm{C}$ & $\mathrm{CW}$ & $\mathrm{R}$ & $\mathrm{LW}$ & $\mathrm{N}$ \\
\hline $\mathrm{U}-111$ & VII & EB & $\mathrm{R}$ & $1 \mathrm{C}$ & & $\mathrm{O}$ \\
\hline $\mathrm{U}-112$ & $\mathrm{XXXN}$ & UK & & & & $\mathrm{N}$ \\
\hline $\mathrm{U}-201$ & $\mathrm{XX}$ & $\mathrm{CW}$ & & & & $\mathrm{N}$ \\
\hline U-202 & $\mathrm{XX}$ & $\mathrm{CW}$ & & . & & $\mathrm{N}$ \\
\hline $\mathrm{U}-203$ & $\mathrm{XX}$ & $\mathrm{CW}$ & & & & $\mathrm{N}$ \\
\hline U-204 & XXXL & $\mathrm{R}$ & $2 \mathrm{C}$ & $\mathrm{CW}$ & & $\mathrm{N}$ \\
\hline
\end{tabular}




\section{Distribution}

No. of

Copies

\section{OFFSITE}

12 DOE/Office of Scientific and Technical Information

S. F. Agnew

Los Alamos National Laboratory

P.O. Box 1663

Los Alamos, NM 87545

\section{ONSITE}

6 DOE Richland Operations Office

R. F. Christensen, K8-50

G. W. Rosenwald, S7-54

Public Reading Room

R. L. Dock File (2)

S. O. Branch

MACTEC

S. J. Murff, R3-82

FAI

M. G. Plys, H4-62
No. of

Copies

6 Westinghouse Hanford Company

H. Babad, S7-30

M. A. Islam, R3-08

A. B. Webb, H4-65

J. P. Sederburg, R2-11

D. A. Turner, S7-15 (2)

37 Pacific Northwest Laboratory

D. M. Camaioni, K2-44

J. A. Campbell, P8-08

R. T. Hallen, P8-38

J. O. Heaberlin, K8-41

P. G. Heasler, K5-12

J. G. Hill, K7-94

M. E. Lerchen, K7-94

P. Mellinger, K9-76

D. R. Payson, K7-90

C. S. Simmons, K9-33

J. J. Toth, K7-94 (15)

P. D. Whitney, K5-12

T. W. Wood, K7-94

Organic Waste Tank Safety

Project File (4)

Publishing Coordination

Technical Report Files (5) 